\title{
RAZVOJ SISTEMA ZA PROJEKTOVANJE I OPTIMIZACIJU KONSTRUKCIJE PRIBORA
}

- DOKTORSKA DISERTACIJA -

Novi Sad, 2010. god. 


\begin{tabular}{|c|c|}
\hline & $\begin{array}{r}\text { UNIVERZITET U NOVOM SADU • FAKULTET TEHNIČKIH NAUKA } \\
21000 \text { NOVI SAD, Trg Dositeja Obradovića } 6\end{array}$ \\
\hline
\end{tabular}

\begin{tabular}{|c|c|c|c|}
\hline \multicolumn{4}{|l|}{ Redni broj, RBR: } \\
\hline \multicolumn{4}{|c|}{ Identifikacioni broj, IBR: } \\
\hline \multicolumn{2}{|c|}{ Tip dokumentacije, TD: } & \multicolumn{2}{|l|}{ Monografska publikacija } \\
\hline \multicolumn{2}{|l|}{ Tip zapisa, TZ: } & \multicolumn{2}{|c|}{ Tekstualni štampani materijal } \\
\hline \multicolumn{2}{|l|}{ Vrsta rada, VR: } & \multicolumn{2}{|l|}{ Doktorska disertacija } \\
\hline \multicolumn{2}{|l|}{ Autor, AU: } & \multicolumn{2}{|l|}{ Đorđe Vukelić } \\
\hline \multicolumn{2}{|l|}{ Mentor, MN: } & \multicolumn{2}{|l|}{ Prof. dr Janko Hodolič } \\
\hline \multicolumn{2}{|l|}{ Naslov rada, NR: } & \multicolumn{2}{|c|}{$\begin{array}{l}\text { Razvoj sistema za projektovanje i optimizaciju } \\
\text { konstrukcije pribora }\end{array}$} \\
\hline \multicolumn{2}{|l|}{ Jezik publikacije, JP: } & \multicolumn{2}{|l|}{ Srpski } \\
\hline \multicolumn{2}{|l|}{ Jezik izvoda, JI: } & \multicolumn{2}{|l|}{ Srpski / Engleski } \\
\hline \multicolumn{2}{|c|}{ Zemlja publikovanja, ZP: } & \multicolumn{2}{|l|}{ Srbija } \\
\hline \multicolumn{2}{|c|}{ Uže geografsko područje, UGP: } & \multicolumn{2}{|l|}{ Vojvodina } \\
\hline \multicolumn{2}{|l|}{ Godina, GO: } & \multicolumn{2}{|l|}{2010} \\
\hline \multicolumn{2}{|l|}{ Izdavač, IZ: } & \multicolumn{2}{|l|}{ Autorski reprint } \\
\hline \multicolumn{2}{|l|}{ Mesto i adresa, MA: } & \multicolumn{2}{|c|}{ Novi Sad, Bulevar oslobođenja 47} \\
\hline \multicolumn{2}{|c|}{$\begin{array}{l}\text { Fizički opis rada, FO: } \\
\text { (poglavlja/strana/citata/tabela/slika/grafika/priloga) }\end{array}$} & \multicolumn{2}{|c|}{$8 / 162$ / 249 / 8 / 112 / 0 / 0} \\
\hline \multicolumn{2}{|l|}{ Naučna oblast, NO: } & \multicolumn{2}{|c|}{ Tehničko-tehnološke nauke } \\
\hline Naučna disciplina, $\mathbf{N}$ & & Mašinsko inženjerstvo & \\
\hline Predmetna odrednica/l & jučne reči, PO: & Pribor, projektovanje, o & \\
\hline UDK & & & \\
\hline Čuva se, ČU: & & Biblioteka Fakulteta teh & u Novom Sadu \\
\hline Važna napomena, V & & & \\
\hline Izvod, IZ: & & $\begin{array}{l}\text { U disertaciji se pri } \\
\text { projektovanje i optimiz } \\
\text { mašinsku obradu. An } \\
\text { projektovanu pribora. } \\
\text { funkcionisanje razvijen } \\
\text { je izvršena na konkte } \\
\text { operacije obrade bušer } \\
\text { odgovarajući zaključci } \\
\text { istraživanja. }\end{array}$ & $\begin{array}{l}\text { zvoj sistema za } \\
\text { rukcije pribora za } \\
\text { različiti prilazi u } \\
\text { je koncepcija i } \\
\text { Validacija sistema } \\
\text { n predmetima za } \\
\text { a. Na kraju su dati } \\
\text { i pravci budućih }\end{array}$ \\
\hline Datum prihvatanja te & he, DP: & 21.05 .2008 & \\
\hline Datum odbrane, DO: & & & \\
\hline Članovi komisije, KO: & Predsednik: & Prof. dr Ilija Ćosić & \\
\hline & Član: & Prof. dr Velimir Todić & Potpis mentora \\
\hline & Član: & Prof. dr Bogdan Sovilj & \\
\hline & Član: & Prof. dr Branko Tadić & \\
\hline & Član, mentor: & Prof. dr Janko Hodolič & \\
\hline
\end{tabular}




\begin{tabular}{|r|r|}
\hline & $\begin{array}{r}\text { UNIVERITY OF NOVI SAD • FACULTY OF TECHNICAL SCIENCES } \\
21000 \text { NOVI SAD, Trg Dositeja Obradovića } 6\end{array}$ \\
\hline
\end{tabular}

\begin{tabular}{|c|c|c|c|}
\hline \multicolumn{4}{|c|}{ Accession number, ANO: } \\
\hline \multicolumn{4}{|c|}{ Identification number, INO: } \\
\hline \multicolumn{2}{|l|}{ Document type, DT: } & \multicolumn{2}{|c|}{ Monographic publication } \\
\hline \multicolumn{2}{|l|}{ Type of record, TR: } & \multicolumn{2}{|l|}{ Textual material printed } \\
\hline \multicolumn{2}{|l|}{ Contents code, $\mathbf{C C}$} & \multicolumn{2}{|l|}{ Dr Sci Thesis } \\
\hline \multicolumn{2}{|l|}{ Author, AU: } & \multicolumn{2}{|l|}{ Djordje Vukelic } \\
\hline \multicolumn{2}{|l|}{ Mentor, MN: } & \multicolumn{2}{|l|}{ Dr Sci Janko Hodolic } \\
\hline \multicolumn{4}{|l|}{ Title, TI: } \\
\hline \multicolumn{2}{|l|}{ Language of text, LT: } & \multicolumn{2}{|l|}{ Serbian } \\
\hline \multicolumn{2}{|c|}{ Language of abstract, LA: } & \multicolumn{2}{|l|}{ Serbian / English } \\
\hline \multicolumn{2}{|c|}{ Country of publication, CP: } & \multicolumn{2}{|l|}{ Serbia } \\
\hline \multicolumn{2}{|c|}{ Locality of publication, LP: } & \multicolumn{2}{|l|}{ Vojvodina } \\
\hline \multicolumn{2}{|c|}{ Publication year, PY: } & \multicolumn{2}{|l|}{2010} \\
\hline \multicolumn{2}{|l|}{ Publisher, PB: } & \multicolumn{2}{|l|}{ Authors reprint } \\
\hline \multicolumn{2}{|l|}{ Publication place, PP: } & \multicolumn{2}{|c|}{ Novi Sad, Bulevar oslobodjenja 47} \\
\hline \multicolumn{2}{|c|}{$\begin{array}{l}\text { Physical description, PD: } \\
\text { (chapters/pages/ref./tables/pictures/graphs/appendixes) }\end{array}$} & \multicolumn{2}{|c|}{$8 / 162$ / 249 / 8 / 112 / $0 / 0$} \\
\hline \multicolumn{2}{|l|}{ Scientific field, SF: } & \multicolumn{2}{|c|}{ Technical and technological sciences } \\
\hline \multicolumn{2}{|l|}{ Scientific discipline, SD: } & Mechanical Engineeri & \\
\hline Subject/Key words, $\mathbf{S} /$ & & Fixture, design, optim & \\
\hline UC & & & \\
\hline Holding data, HD: & & Library of the Faculty & hical Sciences \\
\hline Note, $\mathbf{N}$ : & & & \\
\hline Abstract, $\mathbf{A B}$ : & & $\begin{array}{l}\text { The dissertation sho } \\
\text { system for fixture } \\
\text { optimization for macl } \\
\text { approaches were an } \\
\text { The concept and fun } \\
\text { system is presented. } \\
\text { is made with specifi } \\
\text { and milling process o } \\
\text { appropriate conclu } \\
\text { directions for future re }\end{array}$ & $\begin{array}{l}\text { development of } \\
\text { rocessi. Different } \\
\text { in fixture design. } \\
\text { of the developed } \\
\text { on of the system } \\
\text { ieces for drilling } \\
\text { s. At the end the } \\
\text { and possible } \\
\text { are given. }\end{array}$ \\
\hline Accepted by the Scientifi & Board on, ASB: & 21.05 .2008 & \\
\hline Defended on, DE: & & & \\
\hline Defended Board, DB: & President: & Dr Sci llija Cosic & \\
\hline & Member: & Dr Sci Velimir Todic & Menthors sign \\
\hline & Member: & Dr Sci Bogdan Sovilj & \\
\hline & Member: & Dr Sci Branko Tadic & \\
\hline & Member, Mentor: & Dr Sci Janko Hodolic & \\
\hline
\end{tabular}




\section{PREDGOVOR}

Rezultati istraživanja izloženi $u$ ovom radu, proizašli si iz desetogodišnjeg naučno-istraživačkog rada autora u oblasti automatizacije postupaka projektovanja u mašinskoj industriji, posebno u delu koji se odnosi na pribore.

Sprovedena istraživanja su realizovana kroz osam poglavlja. Sam rad, izuzimajući prvo uvodno poglavlje i poslednje u kome je navedena korišćena literatura, može se podeliti na dve celine.

Prva celina, čine je poglavlja 2 i 3 je teoretskog karaktera i sadrži detaljan prikaz istraživačke oblasti sa analizom trenutnog stanja u svetu.

Druga celina rada, data u vidu poglavlja od 4 do 8 , bazirana je više na sopstvenom istraživanju autora. Prvo na konceptu sistema za automatizovano projektovanje i optimizaciju konstrukcije pribora a potom i na računarskoj prezentaciji - verifikaciji sistema na realnim rešenjima u vidu izlaznih rezultata, kao i na njihovoj analizi.

U prvom poglavlju, Uvodna razmatranja, posebna pažnja je skrenuta na pitanje kompleksnosti projektovanja pribora kao i na značaj racionalizacije i automatizacije projektovanja pribora.

Drugo poglavlje, Pregled dosadašnjih istraživanja u području automatizovanog projektovanja pribora, bavi se prikazom i analizom metoda projektovanja pribora, opštim karakteristikama i karakterističnim prilazima iz domena projektovanja pribora. Uzimajući u obzir činjenicu da su mnogobrojni prilazi do sada razvijeni ili se i dalje razvijaju, u radu su prikazani i analizirani neki, po autorovom mišljenju, najvažniji.

Treće poglavlje pod nazivom Kritički osvrt na dosadašnja istraživanja $i$ definisanje cilja rada daje generalni osvrt na do sada primenjene prilaze u automatizovanom projektovanju pribora. U ovom poglavlju izvršeno je globalno upoređenje karakteristika razvijenih sistema. Na osnovu kritičkog osvrta na dosadašnja istraživanja definisan je problem - cilj istraživanja, kao i odgovarajuće hipoteze.

Četvrto poglavlje, Struktura sistema za projektovanje $i$ optimizaciju konstrukcije pribora, ključno je poglavlje doktorske disertacije. Isto sadrži relevantne informacije o razvijenom rešenju sistema za automatizovano projektovanje i optimizaciju konstrukcije pribora. Prvo je definisan model 
kompleksnog sistema, njegova struktura i tok radnji u okviru istog. Potom se na osnovu sistematizacije osnovnih podloga za postavljanje koncepcije sistema, daje struktura ključnih modula sistema: modula za unos ulaznih informacija, modula za planiranje koncepcije pribora, modula za sintezu pribora i modula za izlazne informacije.

U petom poglavlju, Funkcionisanje programskog rešenja sistema, je detaljno prikazano i objašnjeno funkcionisanje programskog rešenja sistema, $\mathrm{tj}$ njegovih ključnih segmenata i modula.

Šesto poglavlje, Verifikacija sistema na konkretnim primerima, obuhvata verifikaciju, odnosno rezultate provere razvijenog sistema za automatizovano projektovanje i optimizaciju konstrukcije pribora kroz konkretne primere zajedno sa analizom dobijenih rezultata. Verifikacija je sprovedena na tri radna predmeta za operacije bušenja i glodanja.

Sedmo poglavlje, Zaključna razmatranja i pravci budućih istraživanja, sadrži ocenu rezultata istraživanja u vidu kritičkog osvrta na dobijene rezultate u odnosu na ono što je planirano. U drugom delu ovog poglavlja dati su pravci budućih istraživanja.

Literatura korišćena u toku istraživanja je navedena u obliku posebnog, osmog poglavlja - Literatura.

Zbog okolnosti pod kojim se postižu ovi rezultati osećam potrebu da izrazim zahvalnost pojedincima koji su doprineli rezultatima ovog istraživanja.

$U$ želji da se dobije što više informacija, sugestija i mišljenja o postavljenom cilju istraživanja u ovom radu, autor je u periodu od 2005. do 2009. god. obavio određeni broj kontakata i prepiski sa određenim brojem stručnjaka i naučnika iz sveta koji se bave problematikom projektovanja pribora. Mnogi stavovi u radu baziraju se na sugestijama iz navedenih kontakata i prepiski. Koristim ovu priliku da im se zahvalim svima koji su na bilo koji način pomogli pri izradi ovog rada, a to su: Dipl. ing. Danilo Zgrabič, Halder Norm Technik, Hoče, (Slovenija); Ph.D. Uroš Župerl, University of Maribor, Faculty of Mechanical Engineering, Maribor, (Slovenia); Ph.D. Shreyes N. Melkote, The George W. Woodruff School of Mechanical Engineering, Georgia Institute of Technology, Atlanta, (USA); Ph.D. Yiming Rong Department of Mechanical Engineering, Worcester Polytechnic Institute, Worcester, (USA); Ph.D. Chris Zhang, Advanced Engineering Design Laboratory, Department of Mechanical Engineering, University of Saskatchewan, Saskatoon, (Canada); Ph.D. Bijan Shirinzadeh, Department of Mechanical Engineering, Monash University, Clayton, (Australia); Ph.D. Kumar Senthil, Department of Mechanical and Production Engineering, National 
University of Singapore, (Singapore); Ph.D. Tien Chien Chang, School of Industrial Engineering, Purdue University, West Lafayette, (USA); Ph.D. Kevin Rong, Department of Mechanical Engineering, Worcester Polytechnic Institute, Worcester, (USA); Ph.D. Joe Cecil, Virtual Enterprise Engineering Laboratory (VEEL), Industrial Engineering Department, New Mexico State University, Las Cruces, (USA) i dr.

Prijatna mi je dužnost da izrazim veliku zahvalnost članovima komisije dr Iliji Ćosiću, dr Velimiru Todiću, dr Bogdanu Sovilju, dr Branku Tadiću i mentoru dr Janku Hodoliču. Njihove su sugestije, saveti i podrška imali presudan uticaj na konačna rešenja prikazana u ovom radu.

Autor koristi ovu priliku da se zahvali svojim kolegama i prijateljima koji su na bilo koji način pomogli pri izradi ovog rada.

Takođe, izražavam posebnu zahvalnost svojoj porodici na razumevanju i pomoći kada mi je to najviše trebalo. Zato ovaj rad smatram i njihovom uspehom. 


\section{SADRŽAJ}

1. Uvodna razmatranja .................................................................... 1

2. Pregled dosadašnjih istraživanja u području automatizovanog projektovanja pribora

2.1. Uvodne napomene ....................................................... 9

2.2. Metode projektovanja pribora .......................................... 10

2.2.1. Manuelno projektovanje pribora ................................ 11

2.2.2. Projektovanje pribora pomoću računara ......................... 12

2.3. Opšte karakteristike sistema za automatizovano projektovanje

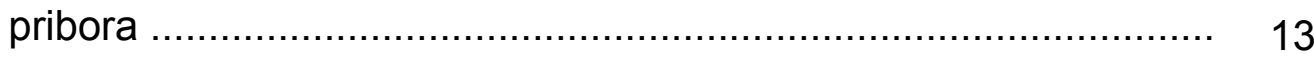

2.4. Karakteristični prilazi u projektovanju pribora ........................... 16

2.4.1. Primena konvencionalnih programa u projektovanju pribora 16

2.4.1.1. Generativni prilaz ....................................... 17

2.4.1.2. Varijantni prilaz .......................................... 18

2.4.1.3. Kompleksni prilaz ..................................... 19

2.4.2. Primena veštačke inteligencije u projektovanju pribora ....... 20

2.4.2.1. Primena ekspertskih sistema u projektovanju pribora 22

2.4.2.1.1. Korisnički interfejs............................... 23

2.4.2.1.2. Baza znanja ......................................... 23

2.4.2.1.2.1. Produkciona pravila .......................... 24

2.4.2.1.2.2. Semantičke mreže ........................ 27

2.4.2.1.2.3. Okviri ........................................ 29

2.4.2.1.3. Mehanizam zaključivanja .......................... 31

2.4.2.2. Primena zaključivanja na osnovu slučaja u projektovanju pribora ........................................ 32

2.4.2.3. Primena neuronskih mreža u projektovanju pribora .. 38

2.4.2.4. Ostala istraživanja u području automatizovanog

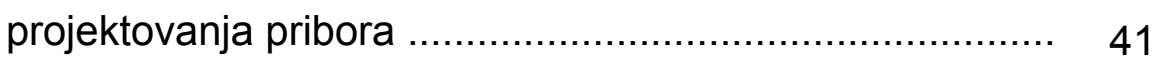


3. Kritički osvrt na dosadašnja istraživanja i definisanje cilja rada ...

3.1. Globalne karakteristike razvijenih sistema ............................. 45

3.2. Postavka hipoteza i cilja rada ............................................ 53

4. Struktura sistema za projektovanje i optimizaciju konstrukcije pribora

4.1. Uvodne napomene ................................................. 55

4.2. Postavljanje koncepcije i razvoj sistema za projektovanje i optimizaciju konstrukcije pribora ......................................... 58

4.2.1. Koncepcije pojedinih modula sistema ........................... 60

4.2.1.1. Modul za unos ulaznih informacija ...................... 60

4.2.1.2. Modul za planiranje koncepcije pribora ................. 63

4.2.1.3. Modul za sintezu pribora .................................. 80

4.2.1.4. Modul za izlazne informacije ............................ 84

5. Funkcionisanje programskog rešenja sistema .......................... 87

5.1. Uvodne napomene .................................................... 87

5.2. Programsko rešenje sistema ............................................. 88

5.2.1. Rešenje baze podataka ...................................... 88

5.2.1.1. Ažuriranje baze podataka ................................. 90

5.2.1.2. Pretraživanje baze podataka ............................. 92

5.2.2. Rešenje baze znanja ........................................... 94

5.2.3. Rešenja modula sistema ........................................ 98

5.2.3.1. Modul za unos ulaznih informacija ....................... 98

5.2.3.2. Modul za planiranje koncepcije pribora .................. 100

5.2.3.3. Modul za sintezu pribora ................................... 104

5.2.3.4. Modul za izlazne informacije ........................... 110

6. Verifikacija sistema na konkretnim primerima ............................. 111

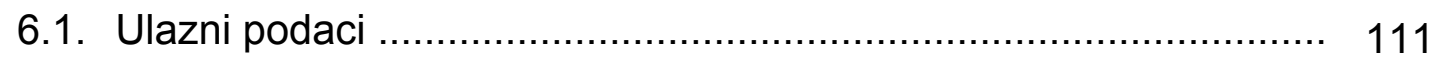

6.2. Definisanje površina za pozicioniranje i stezanje ...................... 114

6.3. Definisanje tačaka za pozicioniranje i stezanje ........................ 117

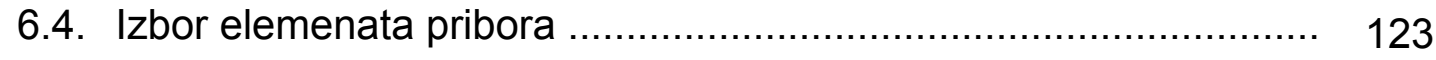


6.5. Generisanje izlaznih informacija ............................................. 124

7. Zaključna razmatranja i pravci budućih istraživanja ........................ 134

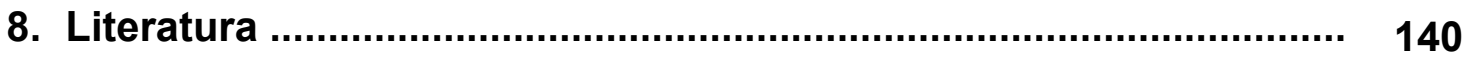




\section{1}

\section{UVODNA RAZMATRANJA}

Savremeni proizvodni sistemi u mašinskoj industriji odlikuju se proširenjem asortimana proizvoda, visokom frekvencijom promene programa proizvodnje, zahtevima za stalnim poboljšanjem kvaliteta proizvoda, smanjenjem rokova i troškova njihove izrade, stalnom potrebom podizanja tehnološkog nivoa proizvoda itd.

Jedna od najvažnijih karakteristika savremenog proizvodnog sistema jeste sposobnost da se u što kraćem vremenu projektuje i proizvede mnoštvo visokokvalitetnih proizvoda. Brzo lansiranje novog proizvoda na tržište, pre nego što to učini konkurencija, predstavlja ključni faktor u obezbeđivanju većeg dela tržišta i viših profitnih stopa. Često su u prvom planu pojedinačna $i$ maloserijska proizvodnja kao rezultat želje potrošača za raznovrsnom ponudom. To sve uslovljava razvoj fleksibilne, agilne proizvodnje koja je sposobna da se brzo prilagodi novim proizvodnim programima.

Ključni aspekt u razvoju proizvoda jesu faze koncepcijskog i detaljnog projektovanja u kojima treba da dođe do stvaranja i vrednovanja ideja za novi proizvod. To može biti dugačak, kompleksan i neretko iterativan proces, koji obuhvata sledeće etape:

- identifikaciju potrebe za nekim proizvodom,

- stvaranje početnih ideja za potencijalno rešenje,

- vrednovanje tih ideja,

- korekciju tih ideja i definisanje dopunskih detalja,

- testiranje ideja u cilju daljeg vrednovanja,

- proizvodnju kompletne specifikacije za odabrano rešenje,

- pripremu neophodne dokumentacije, kao što su radionički crteži, liste potrebnih materijala itd. 
Iz navedenog se uočava da je potrebno ne samo projektovati proizvod, već da to mora biti učinjeno i adekvatnim sredstvima za proizvodnju. Pri projektovanju odgovarajuće tehnološke pripreme proizvodnje svi gore navedeni koraci moraju biti ponovljeni. Očigledno je da troškovi i kašnjenja koji se mogu javiti u toku izrade projektnog rešenja, kako za proizvod, tako i za pripremu proizvodnje, mogu loše delovati na sposobnost preduzeća da zadovolji zahteve tržišta.

Usled strogih zahteva tržišta i intenzivnog razvoja nauke, tehnike i novih tehnologija, nivo i trend daljeg razvoja tehnoloških procesa obrade $u$ industriji prerade metala posmatraju se u svetlu svih činilaca koji ih sačinjavaju i njihovih međusobnih odnosa. Činioci koji najviše utiču na kvalitet tehnoloških rešenja su: vrsta pripremka, obradni procesi, redosled operacija, mašine, strukture operacija, koncentracija operacija i zahvata, alati, pribori, merila i drugo. Da bi tehnološka rešenja podigli na viši nivo, sve ove elemente potrebno je optimalno rešiti.

U lancu faktora uticajnih na izlazne efekte proizvodnih procesa veliki značaj imaju pribori. Kako bi se ustanovile pogodne mere za racionalno korišćenje pribora potrebno je, u prvom koraku, analizirati postojeće stanje. Neadekvatna organizaciona koncepcija u poslovanju sa priborima danas sprečava optimalnu upotrebu već postojećih pribora u gotovo svim domaćim preduzećima metaloprerađivačke industrije, pa čak i svetskim. Da su postojeći resursi često neiskorišćeni, pokazuju istraživanja koja su izvršena nad konstrukcijama pribora u jednom preduzeću (slika 1.1) [232]. Pokazalo se da je među konstrukcijama pribora mnoštvo istih ili sličnih crteža (konstrukcija) pribora. Često se izrađuju nove konstrukcije i u slučaju kada bi i manja izmena na postojećim konstrukcijama bila dovoljna. Izrađuju se novi pribori iako bi se postojeći mogli preraditi i služiti istoj nameni. Takođe, ima slučajeva da postoji odgovarajući pribor, a projektuje se i izrađuje novi.

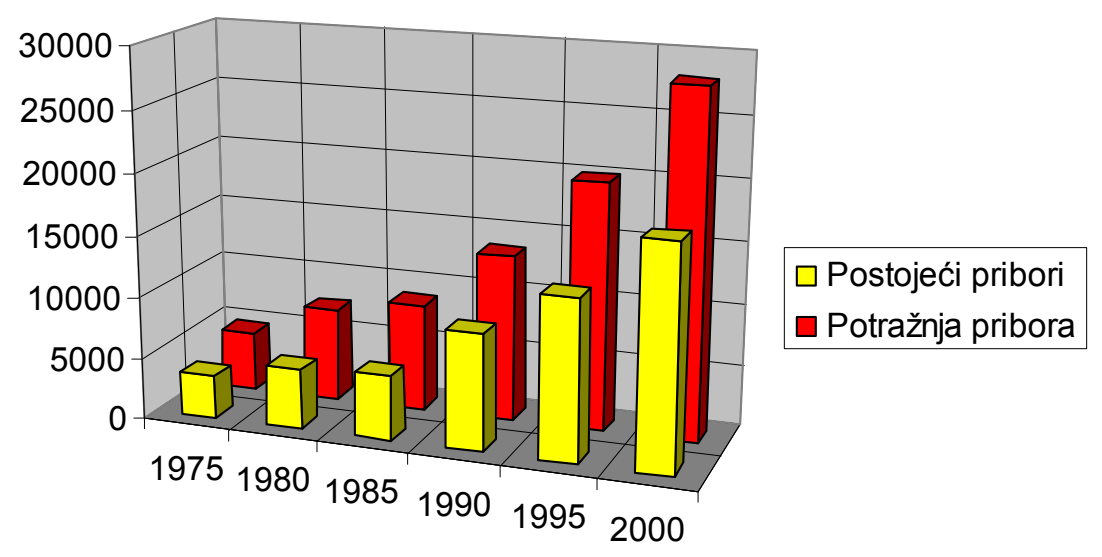

Slika 1.1. Prikaz odnosa postojećih pribora i potražnje istih [232] 
Drugi primer koji odslikava postojeće stanje u području pribora prikazan je na slici 1.2. Iz istraživanja objavljenih u USA [151] proizilazi da je prosečna cena pojedinačne fleksibilne ćelije cca 1,000,000 \$. Od te sume značajan deo investicija otpada na pribore. Troškovi se proporcionalno povećavaju u odnosu na ukupnu cenu. Učešće vrednosti pribora u ceni je prosečno $19 \%$, što govori o tome da se radi o složenim, preciznim, kvalitetnim i efikasnim sklopovima.

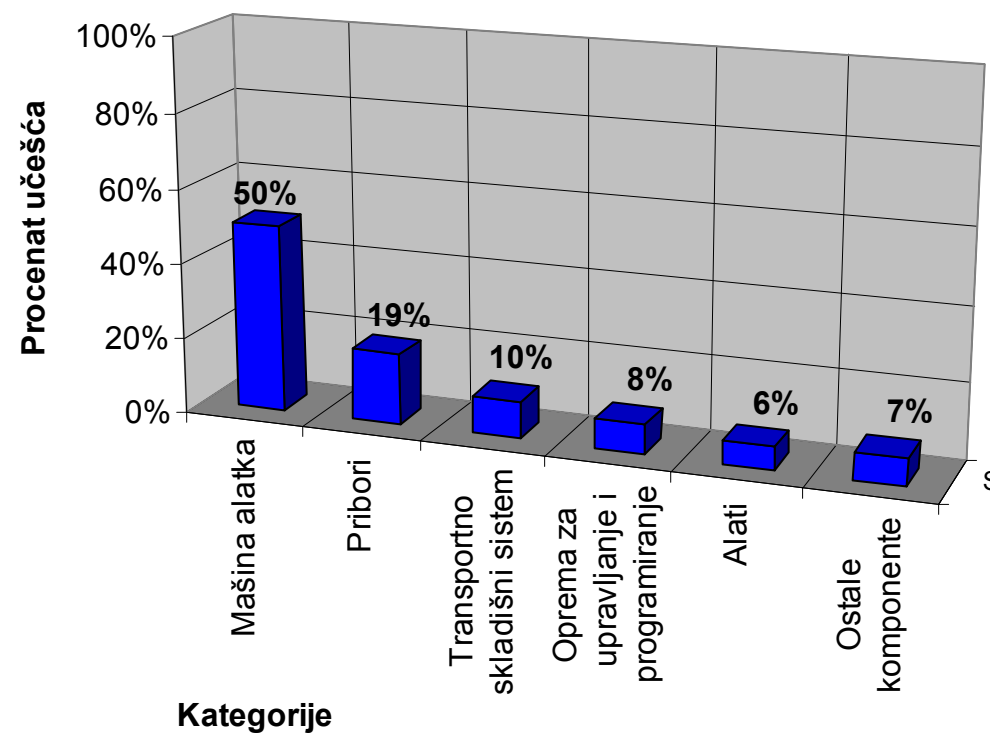

Slika 1.2. Prikaz učešća cena pojedinih komponenti FTĆ u ukupnoj ceni [151]

Problem analize vremena pripreme proizvodnje ima poseban značaj, što je ilustrovano na slici 1.3. Projektovanje pribora, po pravilu, može početi tek kad je potpuno definisan tehnološki postupak obrade. Kao što se sa slike vidi, to vreme traje i do sedam nedelja, a dve nedelje su prosečno vreme potrebno za projektovanje pribora [232].

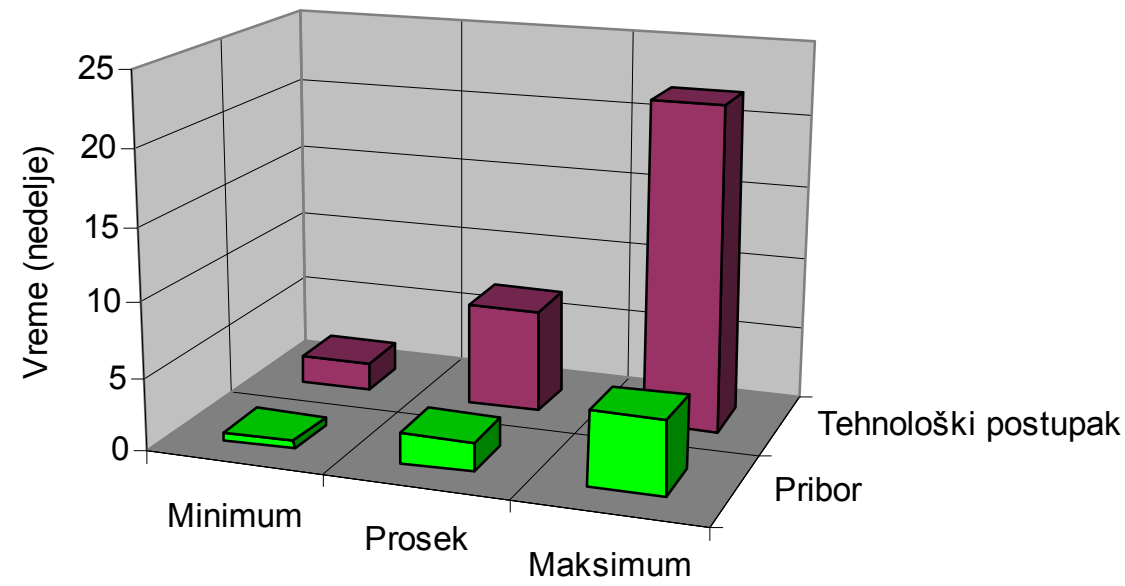

Slika 1.3. Prikaz vremena potrebnog za lansiranje pribora u okviru ukupnog vremena potrebnog za definisanje tehnološkog procesa obrade [232] 
Najviše vremena i najviše okvirnih pripadajućih troškova pri manuelnom projektovanju pribora potrebno je za [3, 128, 146, 163, 164]:

- razradu opšteg vida konstrukcije,

- detaljnu razradu konstrukcije,

- traženje potrebnih informacija o postojećim rešenjima pribora, elementima pribora i sl.

Za sve ostale aktivnosti vreme rada je znatno kraće, a pripadajući troškovi manji. Takve aktivnosti su, pre svega: upoznavanje sa zadatkom projektovanja, izvođenje neophodnih proračuna, sastavljanje sastavnice, kontrola i drugo. Zato je celishodno automatizovati bar one funkcije za čiju realizaciju je neophodno više vremena, a samim tim i više pripadajućih troškova.

Navedena saznanja nametnula su potrebu za uvođenjem novih tehnologija u proces projektovanja pribora, koje se zasnivaju na tzv. fleksibilnoj automatizaciji, a čiji je osnovni cilj smanjenje vremena i troškova projektovanja novih konstrukcija pribora, kao i ponovna upotreba postojećih rešenja pribora sa doradom ili bez dorade pribora. Automatizacija postupaka projektovanja pribora rešava se primenom sistema za automatizovano projektovanje pribora - CAFD (Computer Aided Fixture Design). Rezultati istraživanja u ovoj oblasti doveli su do sistematizovanog poznavanja mogućnosti koje pruža primena računara u projektovanju $[65,66]$.

U proteklim godinama računari se sve više koriste da potpomognu projektantske aktivnosti. Njihova prva primena zabeležena je 60-tih godina prošlog veka sa ciljem direktnog upravljanja mašinama alatkama. Posle toga dolazi do ekspanzije primene računara. Razvija se koncept fleksibilnog proizvodnog sistema i računarom podržane proizvodnje. Danas je akcenat stavljen na inteligentne proizvodne sisteme koji se karakterišu sposobnošću rešavanja problema bez detaljnog i eksplicitnog algoritma, matematičke interpretacije i relacija. Različiti CAx (Computer Aided Everything) sistemi se koriste kao pomoć pri projektovanju proizvoda i proizvodnje kako bi se smanjili vreme i troškovi realizacije ovih koraka u procesu proizvodnje. Razvijeni su mnogi sistemi koji obezbeđuju pomoć na različitim nivoima projektovanja i proizvodnje. Na primer, prilikom projektovanja, CAD (Computer Aided Design) sistemi mogu da predvide očekivano ponašanje projektnog rešenja, da pomognu projektantu $u$ donošenju odluka, te da pomognu $u$ brzom vrednovanju različitih projektnih rešenja. U toku proizvodnje, CAM (Computer Aided Manufacturing) sistemi mogu da pruže pomoć u izradi tehnološkog 
postupka, razmeni podataka, planiranju potrebnih materijala, generisanju putanja alata itd. Takvi računarski alati koriste se kao podrška mnogim delovima proizvodnog procesa.

Jedna od bitnih komponenti proizvodnje jeste pribor. $U$ toku brojnih operacija kroz koje radni predmet prolazi, a koje čine deo proizvodnog procesa, radni predmet mora biti pouzdano pozicioniran i stegnut. Dakle, pribor je uređaj koji se koristi za brzo i pouzdano baziranje radnog predmeta, kao i za oslanjanje i stezanje, na način koji obezbeđuje izradu radnih predmeta u zadatim tolerancijama obrade. Tako se obezbeđuje zamenjivost delova koja danas preovlađuje u modernoj proizvodnji.

Računarske tehnologije unele su revoluciju u način na koji se danas odvija proizvodnja. Od samostalnih CAD/CAM aplikacija, do PDM/ERP (Product Data Management/Enterprise Resource Planning) sistema, računarske tehnologije ispunile su san svakog proizvođača - kraće vreme razvoja proizvoda, viši kvalitet proizvoda i sniženje troškova. Računarom podržano projektovanje pribora (CAFD) postalo je moguće kao etapa ove revolucije tako što su znanje o projektovanju pribora i CAD platforme integrisani u jednu celinu. U cilju smanjenja troškova pribora, tokom godina razvijeni su razni CAFD sistemi koji predstavljaju pomoć projektantu pribora. Mnoga istraživanja su usmerena ka razvoju sistema za projektovanje pribora $\mathrm{i}$ još uvek postoji potreba za razvojem postupka koji će pružiti pomoć projektantu na nivou elemenata pribora, gde je ključni zadatak identifikacija adekvatne strukture pribora, $\mathrm{tj}$. optimalnog broja i rasporeda elemenata po određenim kriterijumima. lako je primarna funkcija pribora tačno baziranje i stezanje radnog predmeta, postoje i mnogi drugi kriterijumi koje bi trebalo zadovoljiti, a koji se najčešće tiču ergonomskih faktora. Konačno, jedan od najznačajnijih aspekata pribora jeste da pribor ne bi trebalo nepotrebno da povećava troškove proizvodnje, npr. usled dužeg trajanja montaže, skupih materijala, troškova proizvodnje pribora, itd. Još jedan aspekt u vezi sa projektovanjem pribora jeste da su različiti zahtevi koje projektno rešenje mora da ispuni obično jedan drugom suprotstavljeni. Na primer, težak pribor može biti poželjan sa stanovišta stabilnosti radnog predmeta. Međutim, povećanje težine pribora može uticati na stvaranje dodatnih troškova, zbog povećanih troškova materijala, kao i zbog otežanog rukovanja priborom. Svi ovi zahtevi doprinose složenosti projektovanja pribora. Pribori direktno utiču na kvalitet obrade, produktivnost i cenu proizvoda. Troškovi u vezi sa projektovanjem i proizvodnjom pribora mogu da učestvuju sa 10-20\% u ukupnim troškovima proizvodnje [11]. Ovi troškovi ne odnose se samo na troškove materijala, izrade i montaže pribora, već i na troškove projektovanja pribora. Sniženjem troškova projektovanja pribora postižu se značajni ekonomski efekti. Postoje 
dva prilaza u vezi sa postizanjem ovog cilja. Jedan je usredsređen na razvoj fleksibilnih pribora dok se drugi oslanja na pojednostavljenje procesa projektovanja.

Aktuelnost problematike automatizovanog projektovanja pribora $u$ velikoj meri ilustruju rezultati publikovanih istraživanja (objavljeni radovi u vodećim svetskim časopisima) prikazani na narednim histogramima (slike 1.41.7.).

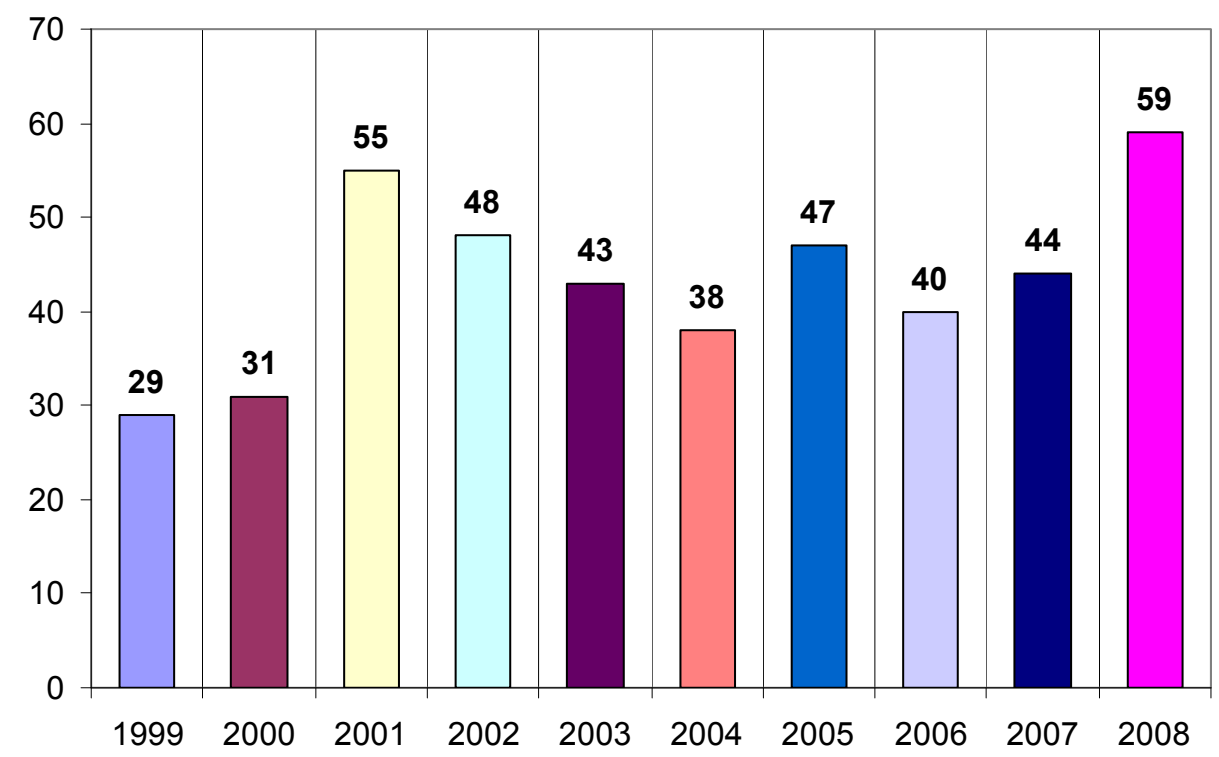

Slika 1.4. Broj publikovanih radova po godinama [233]

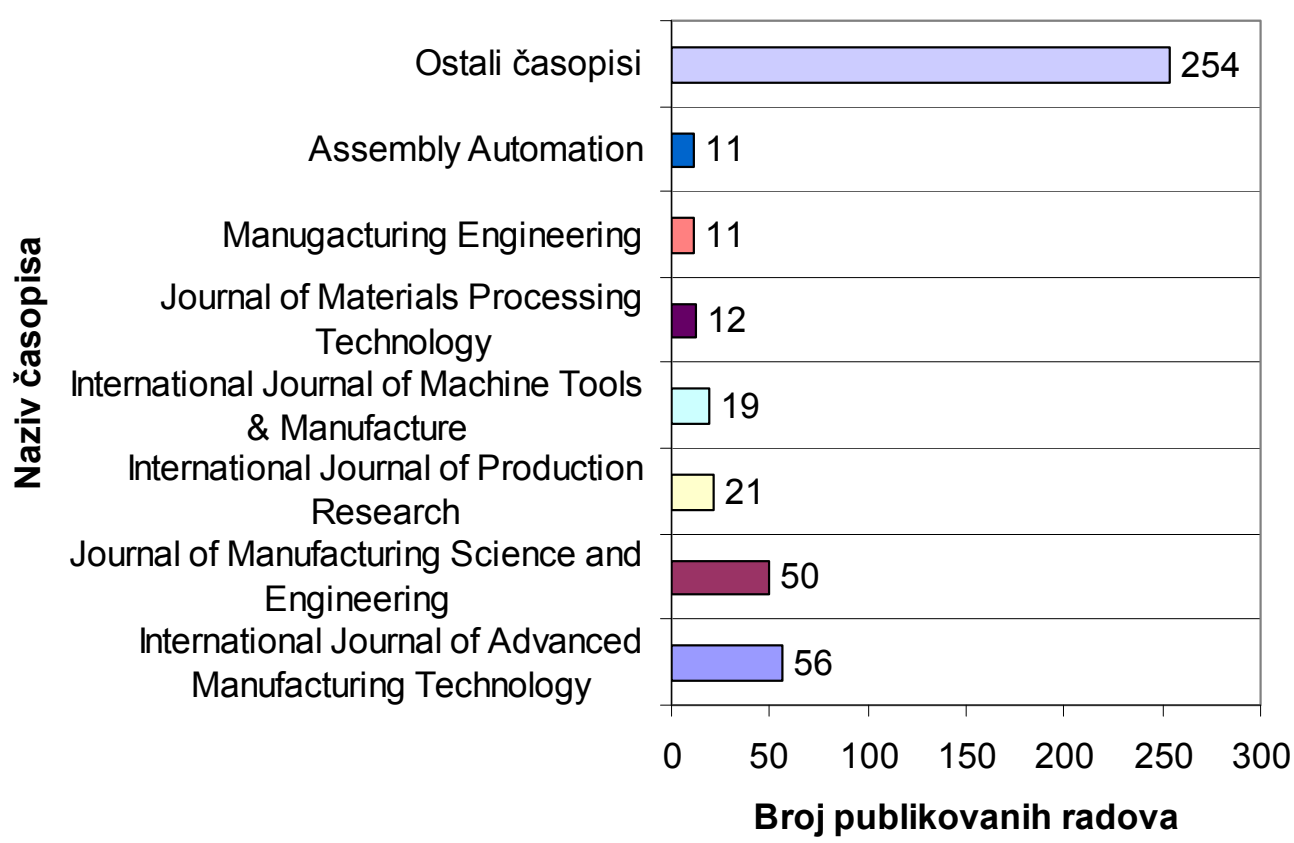

Slika 1.5. Broj publikovanih radova po časopisima [233] 


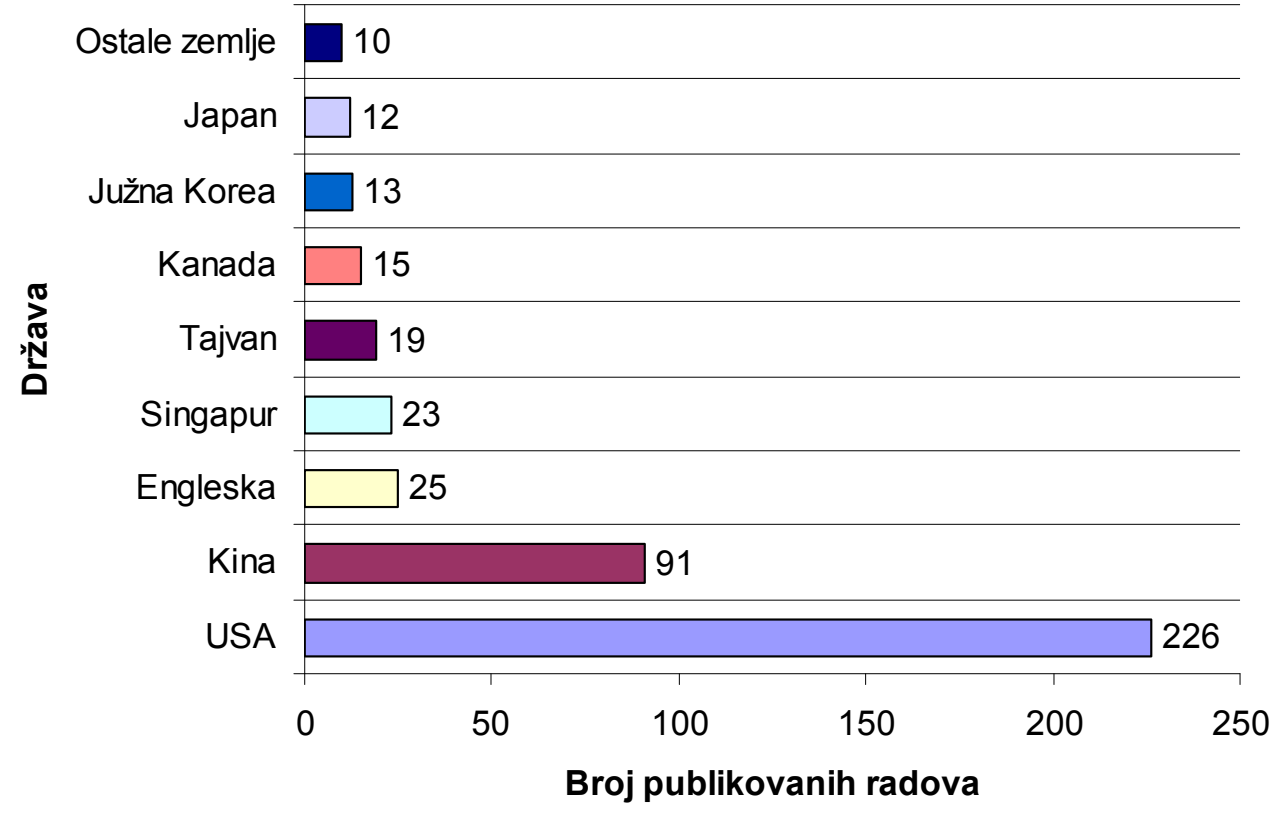

Slika 1.6. Broj publikovanih radova po državama autora [233]

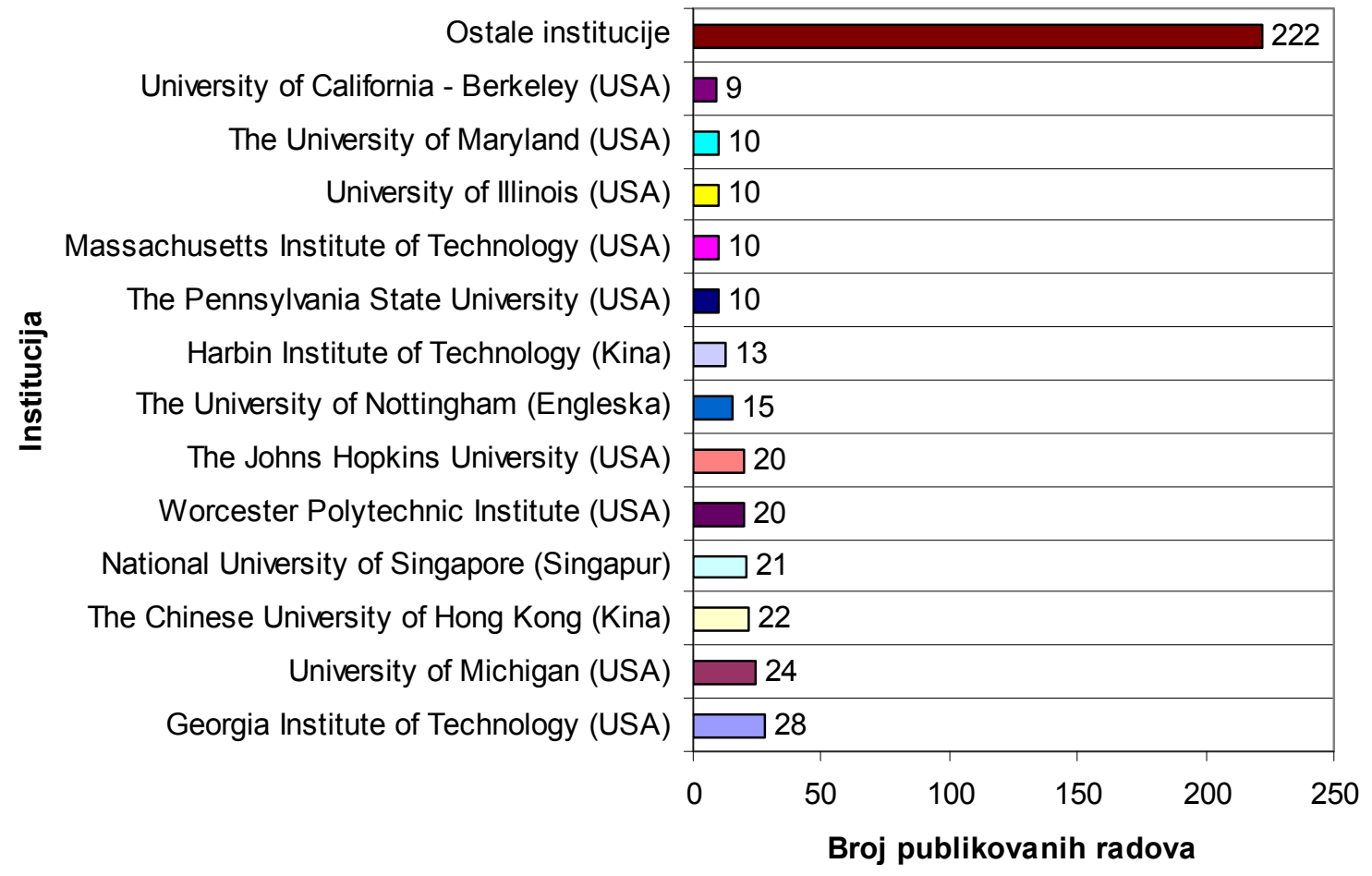

Slika 1.7. Broj publikovanih radova po naučnoistraživačkim institucijama [233]

Shvatajući značaj problematike kompjuterom podržanog projektovanja pribora, Departman za proizvodno mašinstvo Fakulteta tehničkih nauka u Novom Sadu započeo je pre nekoliko godina rad na razvoju sistema za 
automatizovano projektovanje i optimizaciju konstrukcije pribora. Postoje mnogi tipovi proizvodnih operacija (termička obrada, zavarivanje, površinski tretmani, itd.) koji su planirani u razvoju pomenutog sistema. U ovoj disertaciji, akcenat je stavljen na pribore koji se koriste u procesima obrade materijala rezanjem, u kojima se tačnost pozicioniranja meri relativno u odnosu na položaj mašine alatke koja izvodi operaciju obrade. Rad daje detaljan prikaz jedne metodologije koja nastoji da popuni prazninu u oblasti CAFD. Prilaz se sastoji u razmatranju, analizi i sintezi svih operativnih zahteva u vezi sa automatizovanim projektovanjem pribora. 


\section{2}

\section{PREGLED DOSADAŠNJIH ISTRAŽIVANJA U PODRUČJU AUTOMATIZOVANOG PROJEKTOVANJA PRIBORA}

\subsection{UVODNE NAPOMENE}

Konstrukcija pribora u opštem slučaju predstavlja višekomponentnu hijerarhijsku strukturu sa složenim uzajamnim vezama sastavnih elemenata. Raščlanjavanjem na elemente i druga svojstva, pribore možemo tretirati kao tehnički sistem koji se odlikuje sledećim karakteristikama $[75,146,176]$ : vezom sa okolinom, strukturom, funkcijom, skupom konstruktivnih svojstava.

Okolinu pribora čine različiti faktori koji utiču na njegovo projektovanje [180, 181]: mašina alatka, alat, radni predmet, tehnološki postupak, radnik, potrebni tehnoekonomski uslovi (proizvodnost, ekonomičnost, kvalitet) itd. Ovi faktori utiču na strukturu i svojstva konstrukcije pribora. U informacionom planu veza, koje uobličava okolina, obrazuju se konkretna tehnička ograničenja koja je potrebno da zadovolji konstrukcija i koje treba uzeti u obzir u procesu projektovanja pribora.

Struktura pribora može se predstaviti kao hijerarhijska (slika 2.1). Definisana je u sedam nivoa, počev od osnovnih elemenata, površina, grupa površina, konstruktivnih elemenata, grupa konstruktivnih elemenata, funkcionalnih grupa do kompletne konstrukcije pribora.

Svaki sastavni $i$-ti element $j$-tog nivoa raščlanjavanja konstrukcije karakteriše se: oblikom, strukturom, funkcionalnom namenom, dimenzionim karakteristikama, međusobnim odnosima, određenim položajem u trodimenzionalnom prostoru. Među karakteristikama svakog nivoa nalaze se određeni odnosi koji su prouzrokovani ujedinjenjem strukturnih jedinica nižeg 
stepena u strukturne jedinice višeg stepena. Glavni odnosi za konstruisanje su oni koji karakterišu uzajamnost raspoloživih strukturnih jedinica [58].

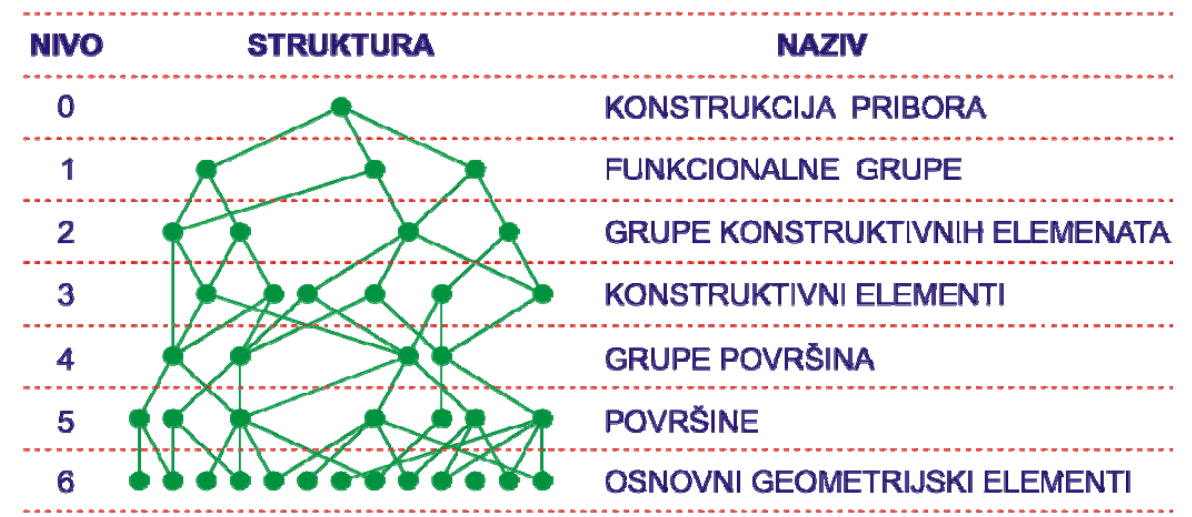

Slika 2.1. Hijerarhijska struktura konstrukcije pribora [58]

Među karakteristikama se nalaze i funkcionalni odnosi (veze). Funkcionalne veze objedinjuju u celinu elemente iz nivoa i izdvajaju strukturne jedinice $u$ višem nivou koji se odlikuje novim funkcionalnim vezama $i$ odnosima. Integralna funkcija konstrukcije pribora ostvaruje se realizacijom posebnih strukturno-funkcionalnih grupa elemenata pribora [58]. Jedan od mogućih načina grupisanja elemenata pribora je grupisanje na:

- elemente za pozicioniranje,

- elemente za stezanje,

- elemente tela pribora

- elemente za vođenje alata,

- elemente za podešavanje položaja alata,

- elemente za vezu,

- ostale elemente pribora.

\subsection{METODE PROJEKTOVANJA PRIBORA}

U odnosu na sredstva koja se koriste, moguća je opšta podela procesa projektovanja pribora na dve osnovne kategorije [129, 132, 166, 167]:

- manuelno projektovanje pribora,

- projektovanje pribora pomoću računara. 


\subsubsection{Manuelno projektovanje pribora}

Ovaj način projektovanja izvodi se u praksi na dva načina, u zavisnosti od toga ko vrši proces projektovanja:

- I način - projektovanje pribora izvodi projektant (konstruktor, inženjer), a montažu monter.

Projektant na osnovu određenih ulaznih informacija (pre svega karte operacije i tehnološkog procesa izrade dela), teorijskih i praktičnih znanja, kao i uz podršku klasičnih inženjerskih sredstava rada (kataloga, priručnika, lenjira, šestara, olovke, gumice itd.) vrši potrebne proračune, definiše koncepciju pribora, bira elemente pribora, crta sklopni crtež (slika 2.2) i potrebne radioničke crteže, definiše sastavnicu, izvodi eventualne korekcije, analize i sl.

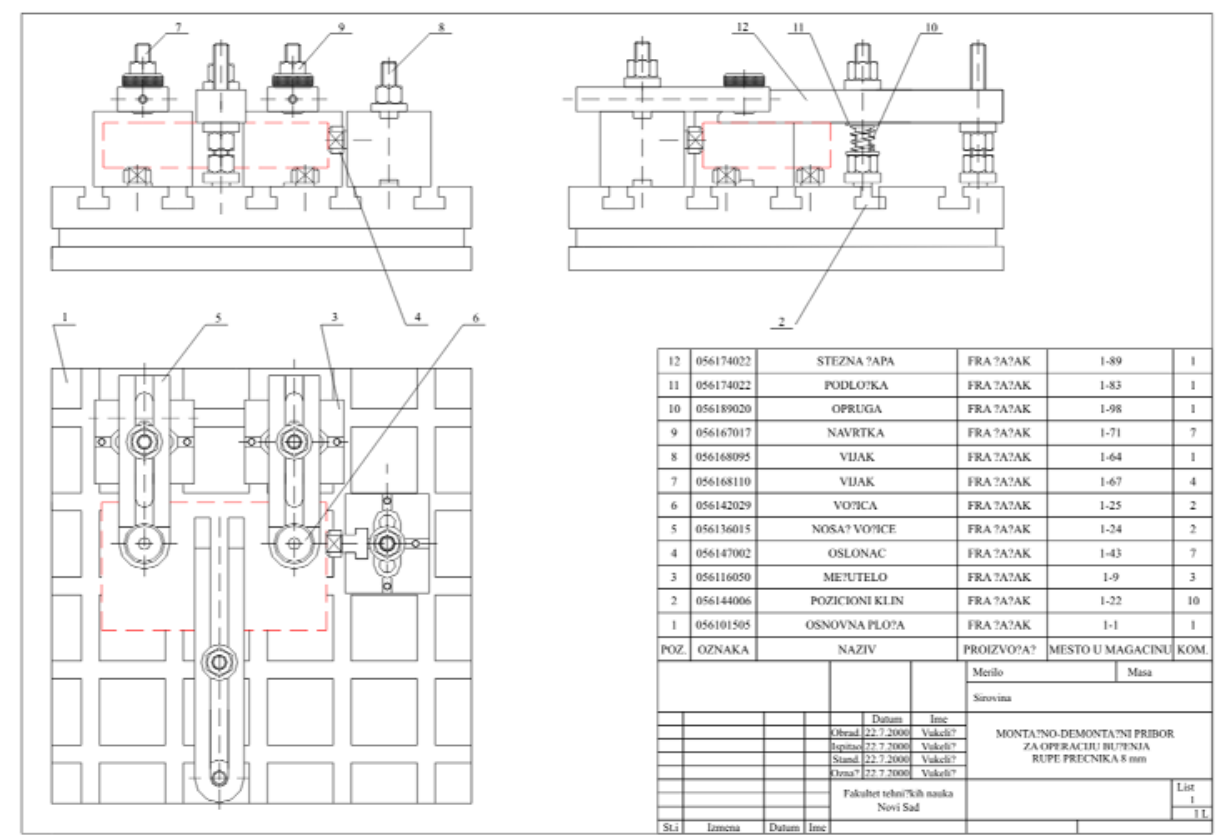

Slika 2.2. Sklopni crtež pribora

- II način - projektovanje pribora i montažu pribora izvodi monter.

Veoma je čest slučaj da projektant uopšte ne učestvuje u procesu projektovanja pribora, već da monter sa određenim kvalifikacijama i radnim iskustvom samostalno rasuđuje o problemu i sastavlja pribor od postojećih elemenata. Ukoliko neki od elemenata nedostaje (ne postoji), on se izrađuje kao specijalni element. Posle sklapanja evidentiraju se svi ugrađeni elementi, pribor se fotografiše, a podaci se čuvaju u karti pribora (slika 2.3). 


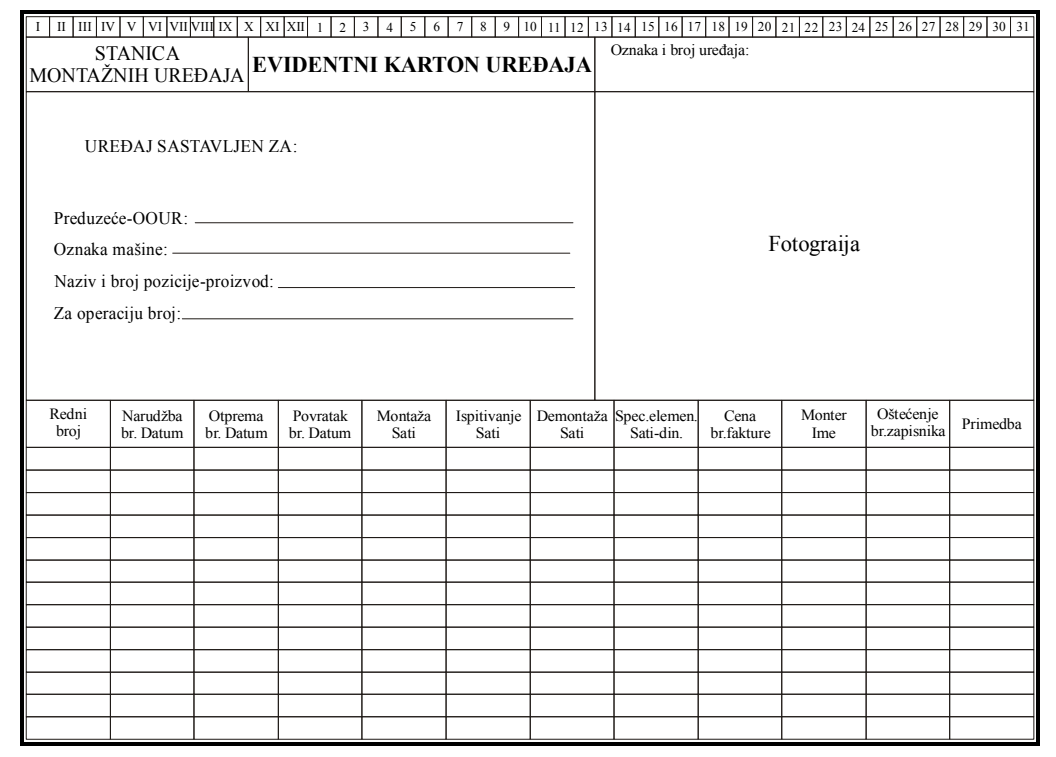

Slika 2.3. Karta pribora („Pobeda Holding AD“, Novi Sad)

\subsubsection{Projektovanje pribora pomoću računara}

Projektovanje pribora pomoću računara (slika 2.4) noviji je vid projektovanja (prvi pokušaji automatizacije projektovanja pribora su se pojavili 80 -tih godina prošlog veka $[4,14,34,50,52,53,71,113,118,119])$, a nastao je kao pokušaj prevazilaženja negativnih aspekata klasičnog načina projektovanja.
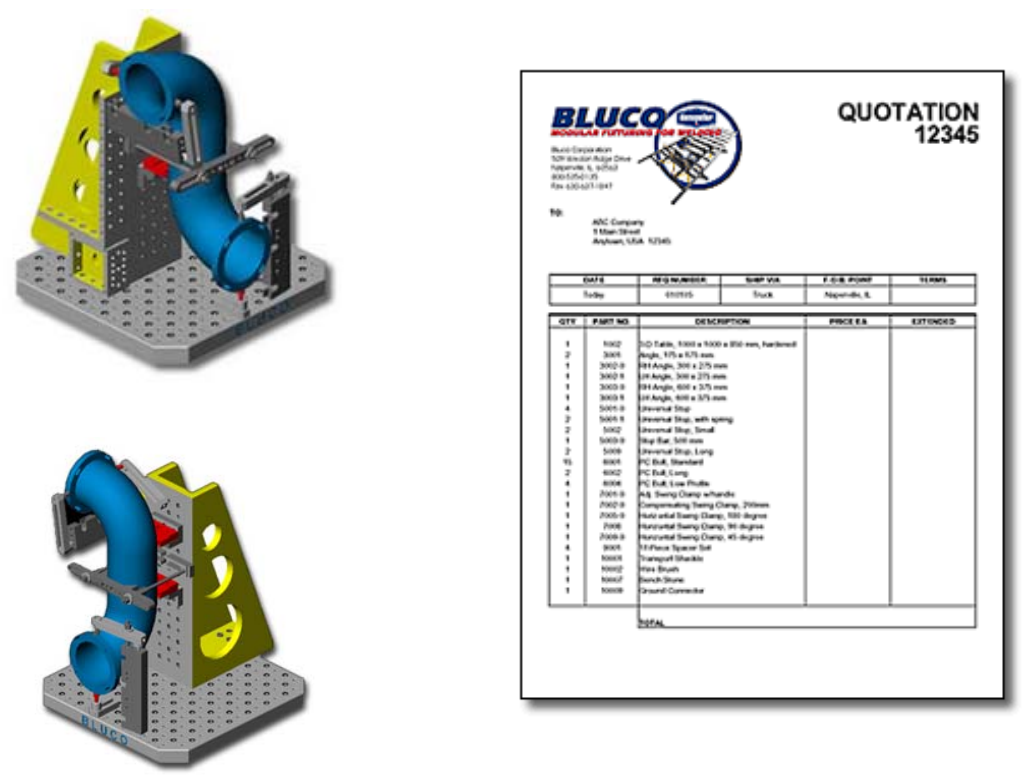

Slika 2.4. Primer izlaznih informacija prilikom projektovanja pribora pomoću računara [234] 
Ovaj vid projektovanja pribora podrazumeva upotrebu računara koji automatizuje sekvence projektovanja pribora. Cilj je da se generiše adekvatan pribor u okviru prihvatljivog vremenskog roka i da se subjektivan uticaj i uloženi napor projektanta svedu na minimum [212, 217]. Najvažnije pretpostavke za primenu računara u procesu projektovanja pribora su „prevođenje“ znanja i iskustva projektanta na jezik razumljiv računaru, zatim razvoj logike izbora i odlučivanja i sl [171, 219].

\subsection{OPŠTE KARAKTERISTIKE SISTEMA ZA AUTOMATIZOVANO PROJEKTOVANJE PRIBORA}

Značaj pribora u proizvodnim sistemima sa automatizovanom proizvodnjom nametnuo je potrebu da se i projektovanju pribora pristupi na savremeni način. Osnovni zadatak je stvaranje uslova koji bi obezbedili projektovanje pribora (u celosti ili makar određenih faza) uz pomoć savremene računarske tehnike i savremenih programskih sistema koji omogućavaju dobijanje kvalitetnih rešenja uz istovremeno smanjenje vremena i troškova projektovanja, kao i uloženog radnog napora i subjektivnog uticaja projektanta $[11,150]$.

U svojoj osnovi, sistemi za automatizovano projektovanje su sistemi koji se temelje na primeni savremenih sredstava informacione tehnologije, a po strukturi i principu funkcionisanja predstavljaju savremene informacione sisteme specijalne namene [149]. Opštu strukturu sistema za automatizovano projektovanje pribora moguće je predstaviti slikom (slika 2.5).

Ulazne informacije u sistemima za automatizovano projektovanje pribora mogu se podeliti na tri veće grupe informacija $[11,122,132,150]$ :

- informacije o radnom predmetu (oblik, geometrija, dimenzije i sl.),

- tehnološke informacije (mašine alatke, alati, režimi obrade itd.)

- informacije vezane za organizaciju i upravljanje proizvodnjom (vreme projektovanja, vreme izrade, i sl.).

Izlazne informacije sadrže sve neophodne podatke za uspešnu montažu i eksploataciju pribora. Prilagođene su potrebama pojedinih korisnika. Neophodne izlazne informacije su [149]:

- sklopni crtež pribora i

- sastavnica pribora. 


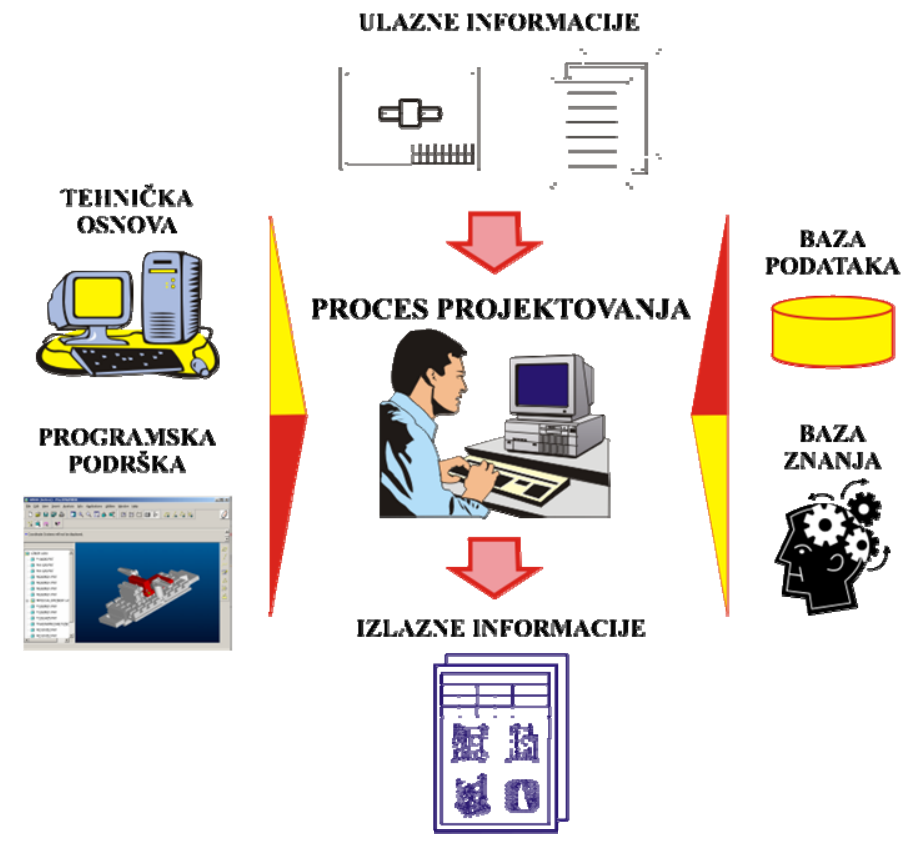

Slika 2.5. Opšta struktura sistema za automatizovano projektovanje pribora [198]

Vrlo često je potrebno dati i radioničke crteže delova (bilo da su oni standardni ili ne), a nešto ređe, između ostalog: težine pojedinih elemenata pribora, ukupnu težinu pribora, mesto u magacinu itd. [22].

Baza znanja se koristi za akviziciju i memorisanje proceduralnog ${ }^{1}$, deklarativnog $^{2}$, heurističkog ${ }^{3}$, strukovnog ${ }^{4}$ znanja i metaznanja ${ }^{5}$ iz domena projektovanja pribora. Znanje se može predstaviti kroz skup sintaktičkih ${ }^{6} \mathrm{i}$

\footnotetext{
${ }^{1}$ Proceduralno znanje (pravila, strategije, agende, procedure). Znanje o procedurama koje opisuju redosled akcija, načine promene stanja i znanje o postupcima za upotrebu znanja. Ovo znanje sugeriše kako se problem rešava i podrazumeva opis metoda i postupaka za rešavanje problema. Za takvo znanje kažemo da je dinamičko. Proceduralno pravilo se može označiti kao pravilo koje opisuje osnovne delove radnji i odnosa [123].

${ }^{2}$ Deklarativno znanje (pojmovi/koncepti, objekti, činjenice). Znanje o odnosima i načinima dekompozicije objekata, pojmova, događaja ili procesa. Ovo znanje sugeriše šta se zna o problemu. Deklarativno znanje je opis informacija neophodnih za rešavanje problema, tj. opis objekata i činjenica, odnosa između objekata i/ili činjenica i opis drugih „pravila“ korisno upotrebljivih za sistem. Takvo znanje se još naziva i statičko znanje [123].

${ }^{3}$ Heurističko znanje predstavlja nepisana iskustvena pravila. Heuristička pravila ( ili heuristika) su pravila za koja bi se pre moglo reći da su sugestije jer se ne mogu dovoljno čvrsto obrazložiti, a ekspert in stiče svojim višegodišnjim iskustvom. Primenjuju se u slučajevima kada zbog nepotpunih ili nepouzdanih informacija ne posedujemo odgovarajuća pravila [123].

${ }^{4}$ Strukturno znanje - skupovi pravila, odnosi između pojmova, odnosi između pojmova i objekata. Mentalni model problema [123].

${ }^{5}$ Metaznanje - znanje o drugim vrstama znanja, kao i o načinu njihovog korišćenja. Znanje o znanju [123].

${ }^{6}$ Sintaksa definiše skup pravila za kombinovanje simbola i formiranje izraza reprezentacijskog jezika. Na osnovu definisanih pravila moguće je jednoznačno odrediti da li je izraz dobro formiran. Dobro formiranim izrazima može se pridružiti značenje. [143]
} 
semantičkih $^{7}$ pravila koja omogućuju opisivanje pribora. Prikaz znanja je prevođenje ili kodiranje ili formaliziranje znanja $u$ format pogodan za rad računara. Brojne su tehnike za prikaz znanja, a koja će se tehnika u konkretnom slučaju upotrebiti zavisi od vrste znanja koje preovladava u promatranom području. Prikaz znanja uvek mora ispuniti dva uslova: ispravno modeliranje tehnika koje bi projektant primenio u rešavanju problema projektovanja pribora i eksplicitno predstavljanje strategija i tehnika rešavanja. Svrha predstavljanja znanja jeste da se ono organizuje u takvoj formi da ga programski sistemi mogu direktno koristiti u procesu projektovanja pribora [65, $66,123]$.

Baza podataka čini osnovu programske podrške. Osnovna joj je namena da obezbedi efektivnost sistema za automatizovano projektovanje kroz kvalitetno i efektivno izvršavanje svojih osnovnih funkcija. Tu se, pre svega, misli na akviziciju, memorisanje, čuvanje, pretraživanje i ažuriranje podataka. Baza podataka sadrži sve neophodne podatke za uspešno funkcionisanje programskih sistema. Ona bi trebalo da bude snabdevena svim potrebnim podacima (tekstualnim, numeričkim i grafičkim) vezanim za gotova konstruktivna rešenja pribora, pojedinačne elemente pribora i radne predmete za koje su projektovani pribori [122, 123, 197].

Pod pojmom tehničke osnove podrazumeva se raspoloživi hardver neophodan za uspešno funkcionisanje programa. Najvažniji zahtevi koji se postavljaju pred tehničku podršku su: što veća brzina rada, velik memorijski kapacitet, kvalitet, pouzdanost itd. [149].

Programsku podršku sistema za automatizovano projektovanje pribora, kao i za automatizovano projektovanje uopšte, čine dva segmenta: operativna programska podrška i aplikativna programska podrška. Operativna programska podrška podrazumeva sve one programe koji imaju namenu puštanja u rad i upravljanja radom tehničke osnove, kao i njeno održavanje $u$ funkciji. Aplikativna programska podrška koristi se za rešavanje određenih zadataka. Aplikativne programe korisnik ili kupuje kao gotove proizvode ili samostalno razvija (programira) i koristi za projektovanje [149, 150].

Kadrove za razvoj, eksploataciju i održavanje sistema u funkciji čini grupa ljudi. Deo tima razvija sistem za automatizovano projektovanje, deo ga eksploatiše, a deo održava u funkciji. Često se oblasti delovanja preklapaju. Ponekad jedan čovek obavlja sve tri funkcije $[149,150]$.

\footnotetext{
${ }^{7}$ Semantika definiše kako definisani izrazi treba da budu interpretirani, odnosno kako izvesti značenje iz forme. Značenje se prvo pridružuje objektima jezika, a potom se proširuje na složenije jezičke strukture.
} 


\subsection{KARAKTERISTIČNI PRILAZI U PROJEKTOVANJU PRIBORA}

U protekle dve decenije mnogo je naučnika uložilo veliki napor kako bi se proces projektovanja pribora racionalizovao, tj. automatizovao. Brojni su primeri razvijenih sistema. Istraživanja literaturnih informacija, lični kontakti i prepiske autora sa stručnjacima i naučnicima iz posmatranog područja pokazali su da su do sada postojala dva glavna pravca (prilaza) u automatizaciji projektovanja pribora, a čine ih [11, 132]:

- konvencionalni programski sistemi i

- programski sistemi bazirani na veštačkoj inteligenciji.

U nastavku ovog poglavlja daje se prikaz osnovnih karakteristika određenog broja razvijenih sistema za automatizovano projektovanje pribora. Prikaz sistema je izvršen na osnovu prepiske sa autorima razvijenih sistema $u$ svetu, informacija iz određenog broja literaturnih referenci navedenih na kraju rada i analize autora ovog rada. Karakteristični primeri sistema su prikazani prema prethodno nabrojanoj sistematizaciji.

\subsubsection{Primena konvencionalnih programa u projektovanju pribora}

Konvencionalni programi uglavnom se upotrebljavaju za obradu podataka koji su najčešće numeričkog tipa. Ova obrada vrši se prema jasnim i tačno definisanim algoritmima koji korak po korak vode sistem (program) ka rešenju konstrukcije. Ukoliko program po svojoj semantici odgovara postavljenom problemu i ukoliko su ulazni podaci tačni, konvencionalni program će rezultirati tačnim rešenjem. U konvencionalnim obradama podataka proceduralno znanje iz domena projektovanja pribora je $u$ programima, a deklarativno u podacima smeštenim u datotekama ili bazama podataka [122, 123, 149, 150].

U zavisnosti od prilaza automatizacije projektovanja pribora, tj. od određene logike odlučivanja, sistemi za automatizovano projektovanje pribora mogu se podeliti u tri kategorije [122, 149]:

- generativne sisteme za automatizovano projektovanje pribora,

- varijantne sisteme za automatizovano projektovanje pribora,

- kompleksne sisteme za automatizovano projektovanje pribora. 


\subsubsection{Generativni prilaz}

Ovaj princip projektovanja pribora primenjuje se u situacijama kada se razvija sasvim novo konstruktivno rešenje pribora, nezavisno za svaki proizvod, bez prethodnog razvrstavanja u grupe ili modifikovanja postojećih rešenja pribora (slike 2.6. i 2.7.) Generisanje nove konstrukcije pribora vrši se na osnovu određenog logičkog algoritma koji bi trebalo da oponaša logiku i način rada projektanta pribora. Na osnovu ugrađenog logičkog algoritma vrši se izbor elemenata pribora, kao i njegovo sastavljanje. Većina do sada razvijenih generativnih sistema sadrži u manjoj ili većoj meri sledeće korake [122, 149]:

- unos ulaznih informacija neophodnih za projektovanje pribora,

- projektovanje potrebnog pribora na osnovu standardnih i tipiziranih elemenata memorisanih u bazi podataka,

- sprovođenje odgovarajućih analiza,

- definisanje izlaznih rezultata (štampanje potrebne tehničke dokumentacije).

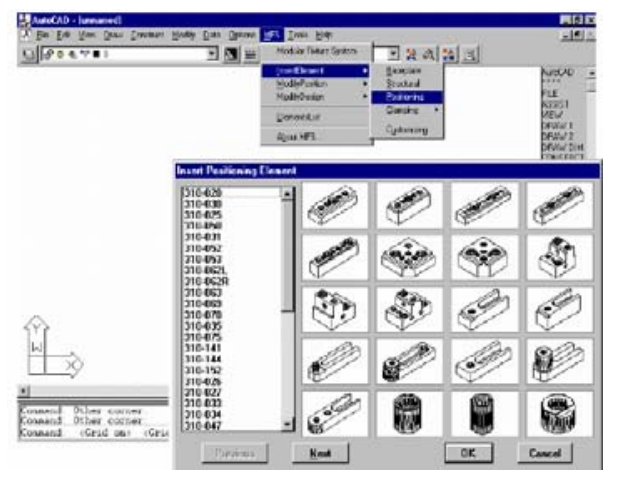

Slika 2.6. Deo sistema namenjen izboru elemenata za pozicioniranje $[161,162]$
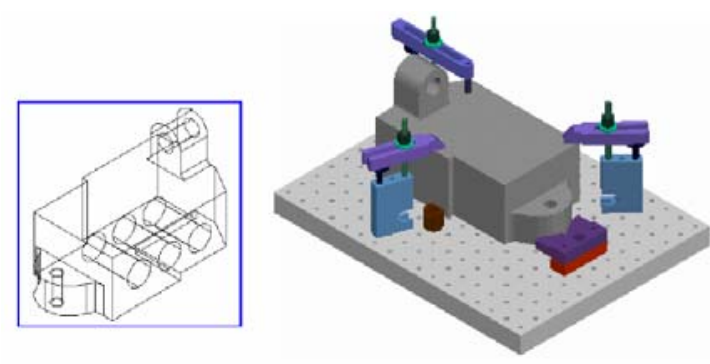

Slika 2.7. Radni predmet i odgovarajući pribor projektovan pomoću generativnog sistema [161, 162]

Primenom generativnih sistema za automatizovano projektovanje pribora ubrzava se proces projektovanja novih (potrebnih) rešenja pribora, a time smanjuju troškovi projektovanja. Brzo je prilagođavanje promeni proizvodnog programa određenog proizvodnog sistema i lako povezivanje (integracija) sa drugim sistemima za automatizovano projektovanje. Bitan nedostatak ovih sistema je nemogućnost iskorišćenja prethodno konstruisanih rešenja pribora. 


\subsubsection{Varijantni prilaz}

Primena varijantnog principa projektovanja pribora ima puni smisao i opravdanje u slučajevima kada se ponavljaju ista ili slična rešenja pribora, $\mathrm{tj}$. kada postoji racionalna mogućnost upotrebe prethodno razvijenih koncepcija.

Suština varijantnog principa projektovanja pribora sastoji se u tome da se potrebna konstrukcija pribora dobija na osnovu tipske konstrukcije. Zbog toga se na osnovu neophodnih ulaznih informacija vrši provera da li postoji tipsko rešenje pribora u bazi podataka. Ukoliko ono postoji, prelazi se na projektovanje individualnog rešenja pribora za tačno određeni radni predmet i tačno određenu operaciju obrade. Nakon toga se vrši provera projektovanog rešenja, kao i definisanje izlazne dokumentacije. Ukoliko u bazi ne postoji tipsko rešenje pribora, ono se generiše na osnovu raspoloživih elemenata pribora, potom se vrši njegovo memorisanje, te se na osnovu njega projektuje potreban pribor $[122,149]$.

$\mathrm{Na}$ ovaj način se proces projektovanja ubrzava, a stepen tipizacije i unifikacije rešenja povećava, što doprinosi racionalizaciji procesa projektovanja i svih drugih procesa koji slede kao njegova posledica. Glavni problem se javlja kada dođe do promene proizvodnog programa, jer tada razvijena konstruktivna rešenja pribora mogu da postanu neupotrebljiva [122, 149].

Pribori memorisani u bazi podataka sastoje se od grupe osnovnih, grupe podešljivih (slika 2.8) i grupe izmenljivih (slika 2.9) elemenata.
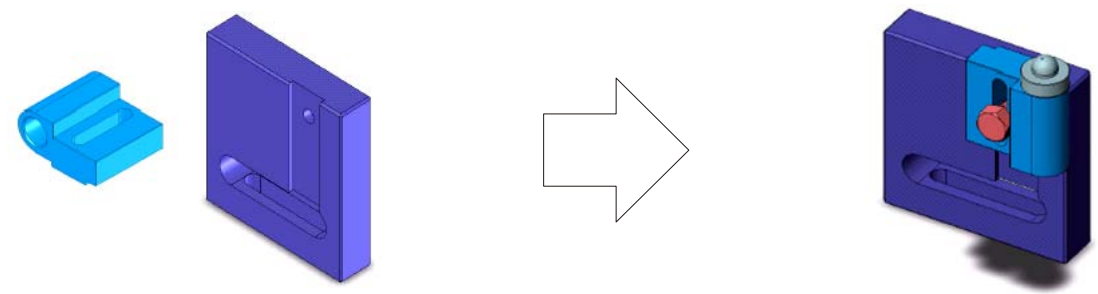

Slika 2.8. Segment podešljivih elemenata [138]
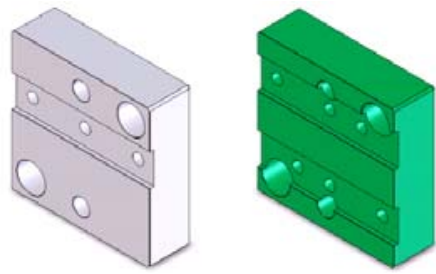

Slika 2.9. Segment izmenljivih elemenata [138] 
Skupovi izmenljivih i podešljivih elemenata čine izmenljive i podešljive podsklopove (slika 2.10).
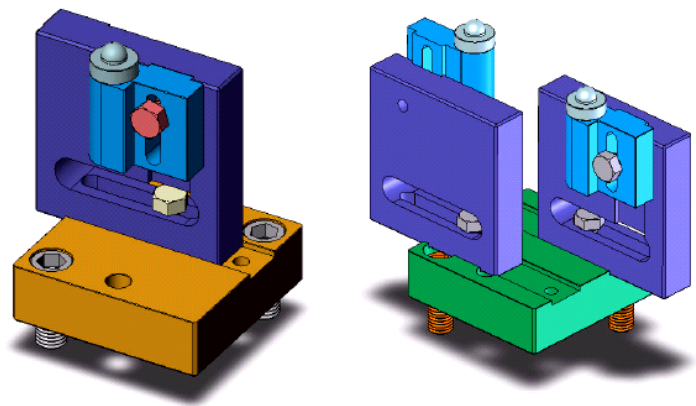

Slika 2.10. Podešljivi i/ili izmenljivi podsklopovi [138]

Upotrebom elemenata i podsklopova, bilo da su oni osnovni, podešljivi ili izmenljivi, vrši se sastavljanje pribora (slika 2.11).

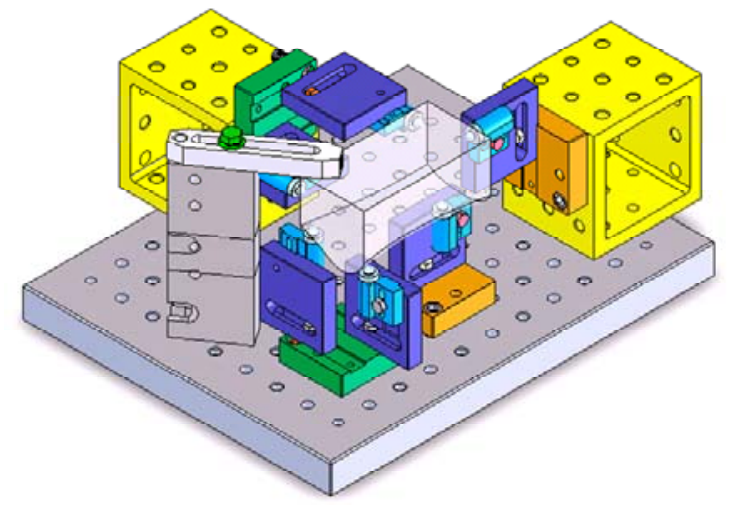

Slika 2.11. Pribor projektovan pomoću varijantnog sistema [138]

\subsubsection{Kompleksni prilaz}

Kompleksni (integralni) sistemi za automatizovano projektovanje pribora nastali su kao posledica usavršavanja i sinteze generativnih i varijantnih sistema za automatizovano projektovanje pribora, sa ciljem objedinjavanja pozitivnih strana i jednih i drugih sistema. Ovi sistemi omogućuju projektovanje kako individualnih, tako i tipskih rešenja pribora (slika 2.12) [122, 146, 149].

Kompleksni sistemi svoj rad zasnivaju na određenom označavanju pribora. Oznaka potrebnog pribora dobija se na osnovu odgovarajućih ulaznih informacija. Potom se pretražuje baza podataka gotovih rešenja pribora. Pošto se uporede oznake potrebnog pribora sa oznakama prethodno projektovanih (memorisanih) pribora, utvrđuje se postojanje potrebnog pribora. Filtriraju se 
pribori (jedan ili više) koji zadovoljavaju postavljene kriterijume. Ukoliko postoji više rešenja, bira se jedno iz grupe mogućih [122, 149].

Ako u bazi podataka ne postoji gotovo rešenje pribora, pristupa se njegovom projektovanju. Projektovanje podrazumeva: definisanje koncepcije pribora, izbor svih potrebnih elemenata pribora (podsklopova, elemenata za pozicioniranje, elemenata za stezanje itd.), analizu projektovanog rešenja i sl. Nakon završenog izbora svih potrebnih elemenata i njihovog sastavljanja, rešenje pribora se memoriše u bazi podataka, kako bi kasnije moglo da se koristi ako se za tim ukaže potreba [122, 146, 149].

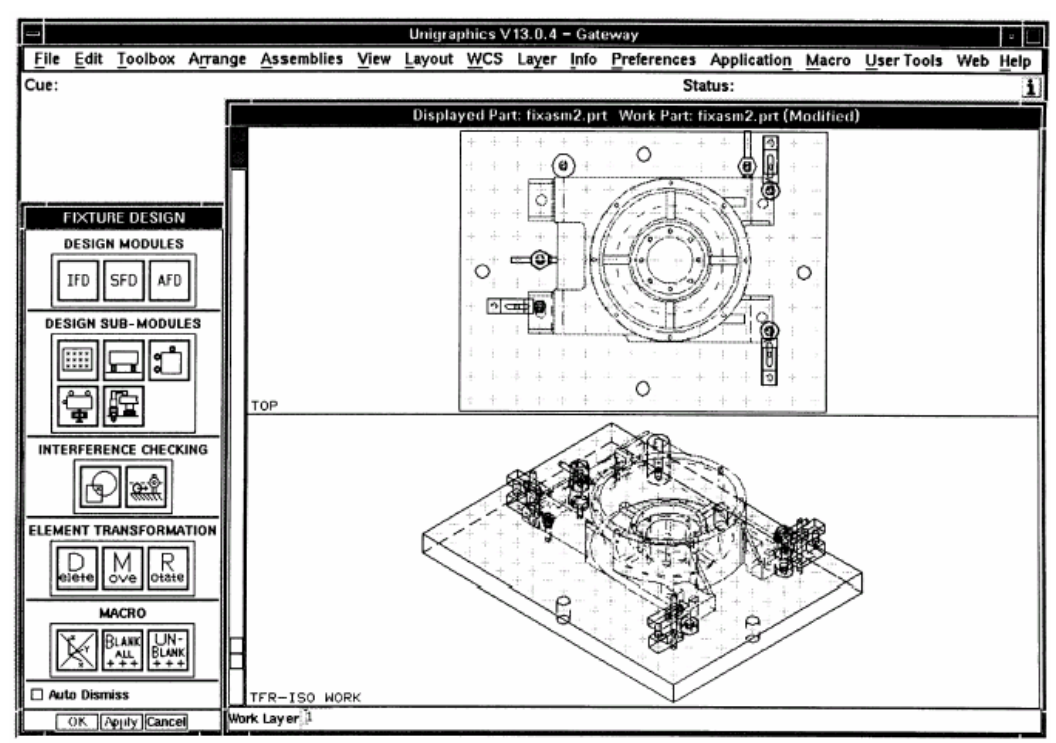

Slika 2.12. Pribor projektovan pomoću kompleksnog sistema [87]

\subsubsection{Primena veštačke inteligencije u projektovanju pribora}

Od davnina je za ljude inteligencija predstavljala intrigantnu oblast kako sam pojam inteligencije, tako i mogućnost konstruisanja „inteligentnih mašina“ koje bi mogle samostalno da rade. $U$ početku su računari prvenstveno bili namenjeni za izvršavanje računskih operacija, ali je vrlo brzo uočeno da su njihove sposobnosti daleko veće. Već su prvi rezultati u primeni računara upućivali na mogućnost računara da preuzme vršenje određenih intelektualnih operacija. Povoljni rezultati istraživanja naveli su neke od naučnika da daju preuranjene izjave da se ubrzo može konstruisati „misleća mašina“ ili „elektronski mozak“. U prošlom veku problematika veštačke inteligencije bila je dosta rasplinuta između fantastike, mašte, potencijalnih mogućnosti i praktičnih ostvarenja. Zanemarivanje razlike između potencijalne ostvarljivosti i 
obima praktičnih problema, koji se nalaze na putu do ostvarivanja ideje, jedan je od čestih uzroka nerazumevanja mogućnosti veštačke inteligencije.

Naporedo sa ostvarivanjem praktičnih rezultata i primenom $u$ industriji, veštačka inteligencija okupirala je sve veći broj naučnika različitih oblasti. Danas postoje sistemi koji su u stanju da autonomno obavljaju kompleksne zadatke i funkcije kakve su jedino ljudi bili u stanju da obavljaju. Nije redak slučaj da takvi sistemi obavljaju zadatke i daleko uspešnije od ljudi. U sprezi sa računarima, mašine postaju sposobne da rade samostalno, da upravljaju same sobom itd., oslobađajući čoveka fizičkog i monotonog rada, prepuštajući mu rad na složenijim i kreativnijim poslovima.

Dva glavna pravca razvoja veštačke inteligencije su [122, 123]:

- proučavanje prirodne inteligencije (spoznavanje funkcija mozga, modeliranje rada mozga, simuliranje čovekovog ponašanja, reagovanja i rezonovanja);

- postizanje inteligentnog ponašanja primenom drugačijih pristupa, kakvi se ne mogu sresti u prirodnim sistemima.

Programi sa uporištem u znanju (knowledge-based software) koji se koriste u okviru veštačke inteligencije razlikuju se od konvencionalnih programa u sledećem [122, 123]:

- konvencionalni programi rade sa podacima kojima se manipuliše dok se knowledge-based sistemi oslanjaju na znanja koja se dalje koriste na odgovarajući način;

- konvencionalni programi koriste samo algoritme dok knowledge-based sistemii koriste i algoritme i heuristiku;

- konvencionalni programi imaju za osnovu procese ponavljanja dok knowledge-based sistemi kao osnovu imaju procese zaključivanja.

$\mathrm{U}$ domenu primene veštačke inteligencije u procesu projektovanja pribora postojala su tri glavna pravca istraživanja $[11,77,122,149]$ :

- primena ekspertskih sistema u automatizovanom projektovanju pribora,

- primena zaključivanja na osnovu slučaja u automatizovanom projektovanju pribora,

- primena neuronskih mreža u automatizovanom projektovanju pribora. 


\subsubsection{Primena ekspertskih sistema u projektovanju pribora}

Ekspertni sistemi su inteligentni programi koji upotrebljavaju znanje i procedure zaključivanja da bi rešili probleme koji su dovoljno teški, te zahtevaju značajnu ljudsku stručnost i veštinu. Nivo potrebnog znanja zajedno sa mehanizmima zaključivanja može se smatrati modelom koji simulira najboljeg stručnjaka u toj oblasti [8]. U pomenutoj definiciji ključne su dve stvari:

- ekspertni sistemi se baziraju na znanju,

- ekspertni sistemi donose zaključke.

Dakle, ekspertni sistem je specifična aplikacija u kojoj se simulira vrhunski stručnjak (ekspert) iz domena projektovanja pribora, na najvećem mogućem nivou stručnosti.

Osnovne komponente svakog ekspertnog sistema razvijenog za potrebe automatizovanog projektovanja pribora su (slika 2.13) [14, 15]:

- korisnički interfejs,

- baza znanja,

- mehanizam zaključivanja.

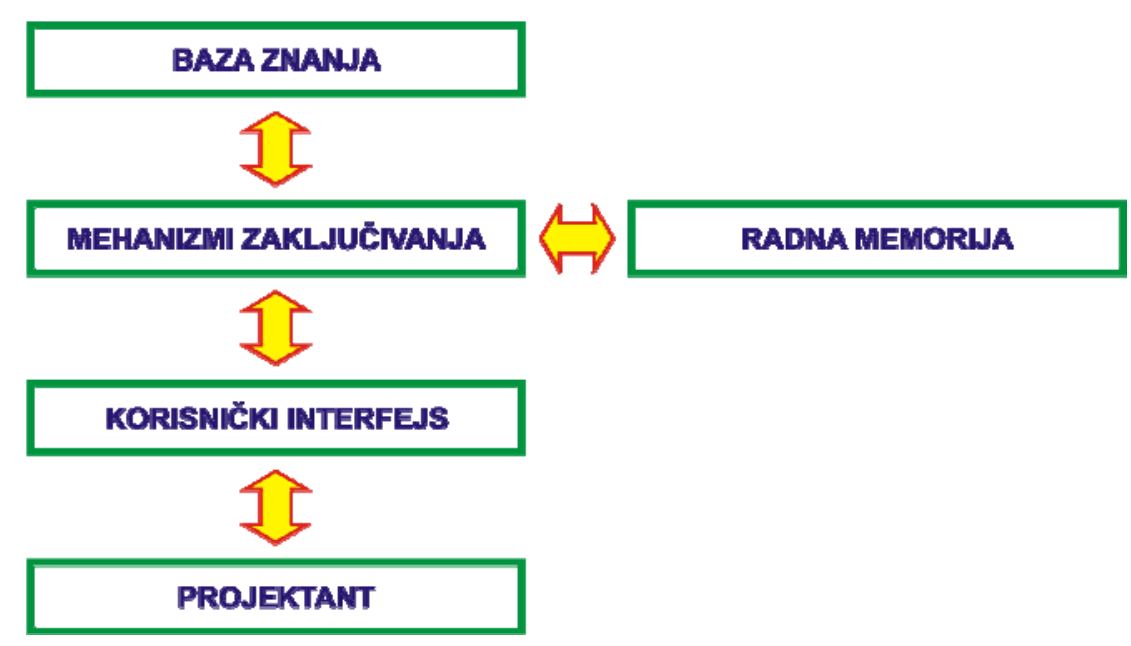

Slika 2.13. Opšta struktura ekspertskog sistema za projektovanje pribora [119] 


\subsection{Korisnički interfejs}

Osnovna uloga ovog segmenta sistema za projektovanje pribora jeste da omogući projektantu što „prijatniji“ rad sa sistemom tokom procedure projektovanja, tj. da obezbedi sledeće [84, 136]:

- jednostavno startovanje programa,

- laku komunikaciju sa korisnikom,

- kontrolu ulaznih informacija,

- kontrolu izlaznih informacija,

- kontrolu grešaka,

- interpretaciju rezultata itd.

Najčešća realizacija korisničkog interfejsa jeste u obliku grafičkog interfejsa i meni dijaloga (slika 2.14).
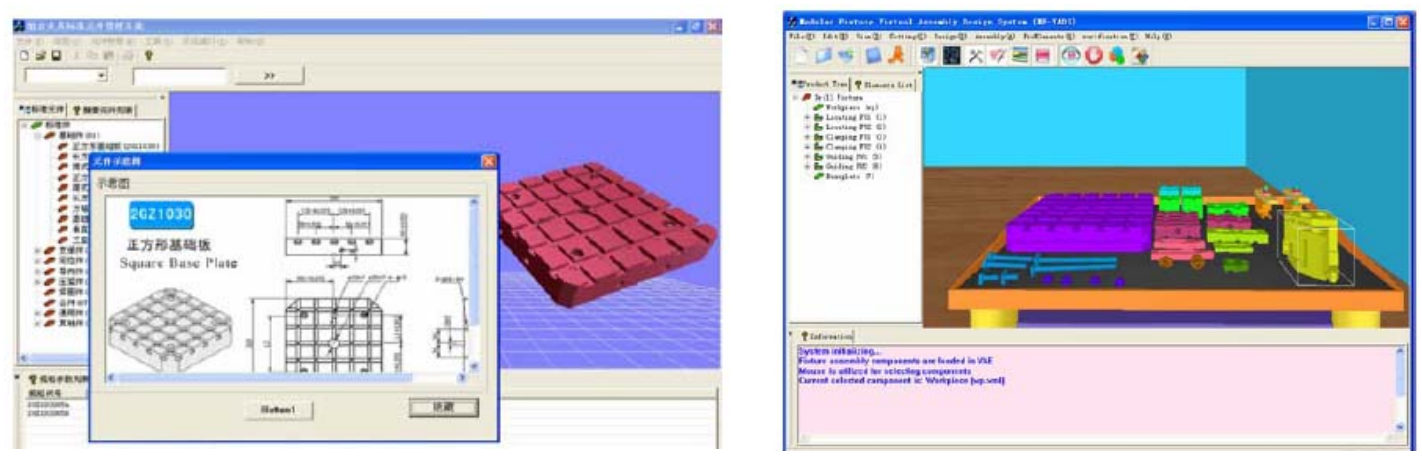

Slika 2.14. Primer korisničkog interfejsa ekspertskog sistema za projektovanje pribora

\subsubsection{Baza znanja}

Baza znanja sadrži činjenice i pravila, odnosno deo znanja eksperta (kao opšteg nivoa znanja o oblasti projektovanja pribora) i njegovog iskustvenog znanja koje ga na najbolji mogući način karakteriše.

Baza znanja predstavlja osnovu ili dušu ekspertnog sistema. Ukoliko ova komponenta nije predstavljena na adekvatan način, ceo postupak implementacije ekspertnog sistema u proces projektovanja pribora može biti uzaludan. 
Osnovno pitanje je kako predstaviti znanje o procesu projektovanja pribora u bazi znanja. Za to postoje različiti načini koji odgovaraju pojedinim tipovima znanja, što znači da podržavaju modularnost, laku modifikaciju baze znanja i omogućavaju predstavljanje heurističkih pravila u oblasti projektovanja pribora. Uobičajeni način predstavljanja znanja vrši se preko tzv. formalizama za predstavljanje znanja. Tako postoji nekoliko metoda predstavljanja znanja u bazi znanja. U području automatizovanog projektovanja pribora korišćene su sledeće tehnike $[16,22,35,125,175]$ :

- produkciona pravila,

- semantičke mreže,

- ramovi znanja (okviri).

\subsection{Produkciona pravila}

Produkciona pravila su opšti metod predstavljanja znanja. Ovim načinom se predstavljaju logičke relacije (veze) među pojmovima koji se javljaju sa istraživanjem problema.

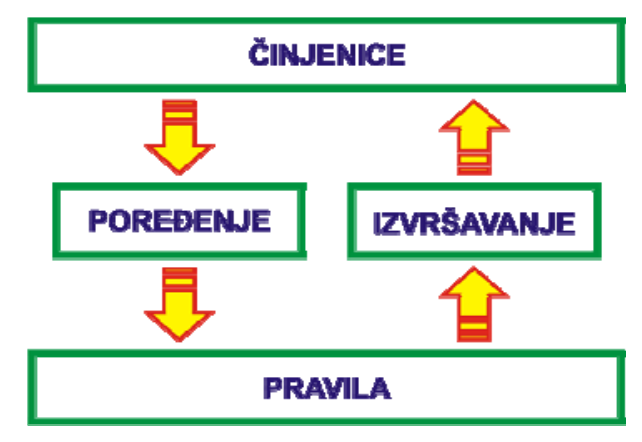

Slika 2.15. Formalizam produkcionih pravila [118]

Ekspertni sitemi kod kojih je znanje predstavljeno u obliku pravila često se nazivaju produkcioni sistemi (rule-based systems). Pravila se mogu shvatiti kao elementi znanja, odnosno elementarne količine znanja iz određenog domena projektovanja pribora. Pravilo predstavlja logičku relaciju i može se izraziti na sledeći način:

$$
\text { ako je } \boldsymbol{X} \text {, tada je } \boldsymbol{Y}
$$

što znači: „ako važi pretpostavka $X$, tada se može zaključiti $Y$ “ ili „ako je situacija $X$, tada se preduzima akcija $Y^{\prime \prime}$. 
Na primer [34]:

$$
\text { ako je }
$$

OSNOVNA BAZNA POVRŠINA OTVOR, onda je

ELEMENT ZA POZICIONIRANJE DUG ČEP

Drugim rečima, pravilo je logički izraz tipa AKO-TADA (If-Then) sa značenjem: ako važi neka premisa (skup premisa), tada se može izvesti zaključak (skup zaključaka) ili se može preduzeti neka akcija (više akcija) [33, 118]. Ovakav način izražavanja znanja je vrlo prirodan i odgovara težnji da znanje bude modularno. Takođe je zadovoljen zahtev za lakom modifikacijom baze znanja jer se nova pravila dodaju nezavisno od ostalih, a sistem je transparentan, tj. lako se objašnjava način na koji se do zaključaka dolazi. Zbog svog oblika, produkciona pravila su pogodan način za predstavljanje one vrste znanja koja je zasnovana na logici.

Zaključci se izvode poređenjem grupe pravila sa skupom činjenica ili znanja o trenutnoj situaciji. Ukoliko je „ako je“ deo pravila zadovoljen, izvršava se akcija određena sa „tada“. Kada se ovo dogodi, kaže se da je pravilo ispaljeno, izvršeno ili okinuto [20,117].

Na primer:

Premise (If)

Operacija obrade $=$ bušenje $($ and $)$

Mašina alatka $=$ vertikalna bušilica (and)

Tip mašine alatke $=$ konvencionalna $($ and $)$

Broj površina za obradu $=1$ (and)

Broj alata $=1$ (and)

Prečnik bušenja $=1$ (and)

Zaključak (Then)

Element za vođenje je fiksna vođica

Opisano pravilo sadrži šest premisa (IF-klauzule) i jedan zaključak (THEN-klauzulu). U opštem slučaju, pravilo može da sadrži veći broj IF i THEN klauzula. IF-klauzule i THEN-klauzule najčešće se mogu formulisati u vidu 
prostih logičkih iskaza. Značenje tih iskaza obično je ispitivanje vrednosti određenih parametara u IF-klauzulama, odnosno dodeljivanje, brisanje ili izmena vrednosti parametara u THEN-klauzulama. THEN-klauzule mogu takođe da predstavljaju i akcije koje treba izvršiti kada su zadovoljene premise pravila. Interesantno je da akcija koja sledi po okidanju pravila može da se odnosi i na modifikaciju baze znanja, odnosno dodavanje novog pravila u bazu ili promenu već postojećeg pravila.

Ovakva ili slična produkciona pravila su razvijana uglavnom za elemente za pozicioniranje $[15,113] \mathrm{i} / \mathrm{ili}$ elemente za stezanje $[84,125]$. Elementi se biraju ponavljanjem pravila sve dok se ne izaberu odgovarajući elementi iz baze modularnih elemenata (sistemi su, po pravilu, bili razvijani za ovu grupu pribora). Ako se dobije veći broj elemenata koji zadovoljavaju zahteve, projektant odlučuje koje će rešenje primeniti (slika 2.16). Izbor elemenata vrši se na osnovu njihove funkcije. Pošto nekoliko modularnih elemenata ima iste funkcije, oni se grupišu zajedno. Pri svakoj upotrebi pravila proverava se funkcija modularnog elementa $[50,84]$.
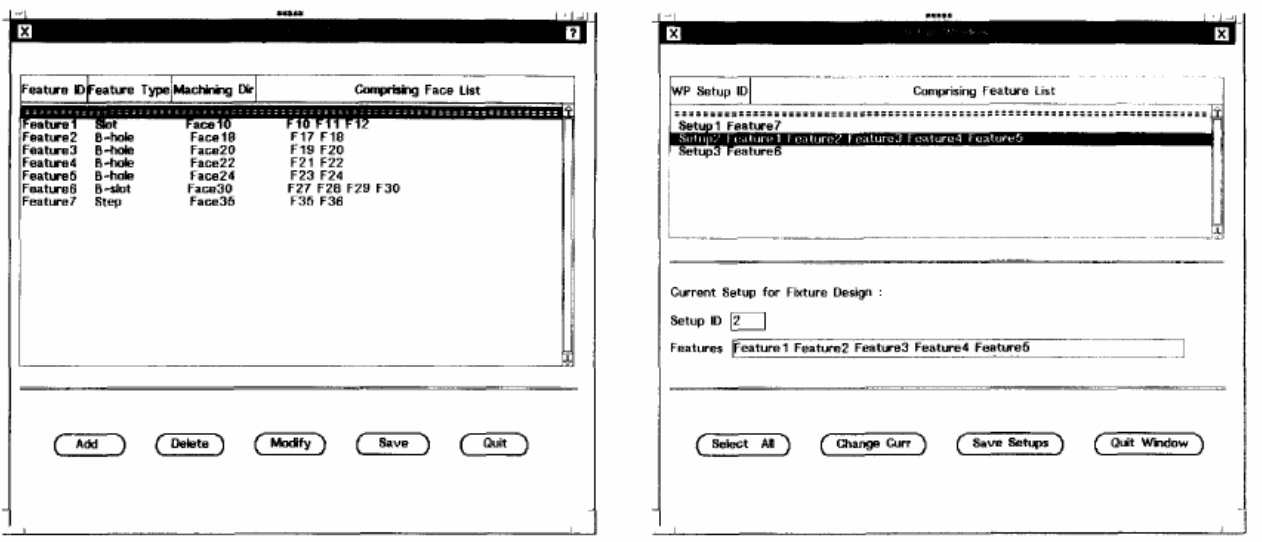

Slika 2.16. Elementi koji zadovoljavaju produkciona pravila [84]

Osnovna ideja kod produkcionih ekspertskih sistema je u tome da se na problem, opisan podacima u radnoj memoriji, iterativno primenjuju pravila iz baze znanja. Ukoliko se opis problema „podudara“ sa IF-klauzulama jednog ili više pravila, rešenje problema se može naći u THEN-klauzuli tog/tih pravila. Važno je naglasiti da se produkciona pravila ne nalaze implementirana u programskom kodu, već su smeštena u bazi znanja kao podaci, sa proizvoljnim redosledom. Mehanizam zaključivanja sadrži u sebi poseban program, tzv. interpretator pravila (rule interpreter), koji je zadužen za procesiranje i interpretaciju ovih pravila u toku rada sistema za projektovanje pribora. 
$U$ prethodnom primeru podrazumeva se da premise važe sa apsolutnom sigurnošću da bi zaključak pravila mogao da se izvede, a samo izvođenje zaključka takođe se vrši sa apsolutnom sigurnošću. Čest je slučaj, međutim, da eksperti pri projektovanju pribora i rešavanju problema izvode zaključke koji važe sa verovatnoćom manjom od 1 odnosno $100 \%$, kao i da se zaključci donose na osnovu podataka koji nisu u potpunosti pouzdani. Produkciona pravila omogućuju da se prikaže i neizvesnost u donošenju odluka. Jedan od najčešćih načina za predstavljanje neizvesnosti je korišćenje faktora izvesnosti (pouzdanosti, verovatnoće) u klauzulama pravila [150, 175]. Faktori izvesnosti su brojevi koji predstavljaju stepen izvesnosti sa kojim se određene činjenice mogu smatrati važećim, odnosno verovatnoću da važe određeni zaključci u slučaju da su prisutni samo neophodni faktori koji ih podržavaju. Tako se pravilima dodaju faktori sigurnosti. Pri tome treba naglasiti da sigurnost nije matematički definisana veličina, već je izraz iskustva eksperta i njegove slobodne i subjektivne procene, odnosno težine koju ima izabrana alternativa. Sam faktor sigurnosti (izvesnosti) definiše se na osnovu odabrane skale koja je najčešće u intervalu od 0 do 100 (mogu biti i drugi intervali npr. od 0 do 1 ili od -1 do 1 itd.), i označava stepen izvesnosti ili poverenja u vrednosti koje se tiču uslova ili zaključka pravila odlučivanja. Faktor izvesnosti jednak nuli označava stanje potpune neizvesnosti, odnosno činjenicu da je vrednost nekog fakta $u$ bazi fakata potpuno nepoznata. Vrednost faktora izvesnosti jednaka 100 označava stanje potpune, odnosno apsolutne izvesnosti posmatranog stanja.

$U$ radnoj memoriji, tokom rada sistema, nalaze se činjenice, tvrđenja, zaključci i drugi relevantni podaci. Ovi podaci su promenljivi, generišu se, menjaju ili gube važnost tokom rada sistema. U sistemima zasnovanim na pravilima, podaci u radnoj memoriji organizovani su u obliku tvrdnji koje su vrlo slične klauzulama pravila. Na osnovu inicijalnih podataka u radnoj memoriji i pravila u bazi znanja, ekspertski sistem izvodi zaključke [150].

\subsection{Semantičke mreže}

Semantičke mreže (slika 2.17.) su strukture koje omogućavaju grafičku prezentaciju informacija o strukturi pribora. Mreže su najopštija i najstarija prezentaciona šema. Semantičke mreže su grupe objekata, odnosno čvorova (nodes) koji su povezani orijentisanim lukovima (arcs), odnosno granama (links) koje predstavljaju relacije između objekata, odnosno stavljaju objekte u određeni odnos. Čvorovi i grane su označeni imenima objekata, odnosno 
relacija koje povezuju objekte, čime je određena semantika mreže. Reč "objekat" ovde se koristi u apstraktnom značenju. U suštini, čvorovi mogu da predstavljaju fizičke objekte, pojmove, osobe, događaje itd. Grane mogu da označavaju različite vrste odnosa između objekata, a tipični odnosi su odnosi pripadanja vrsti, odnos posedovanja, odnos atributa i sl. [33].

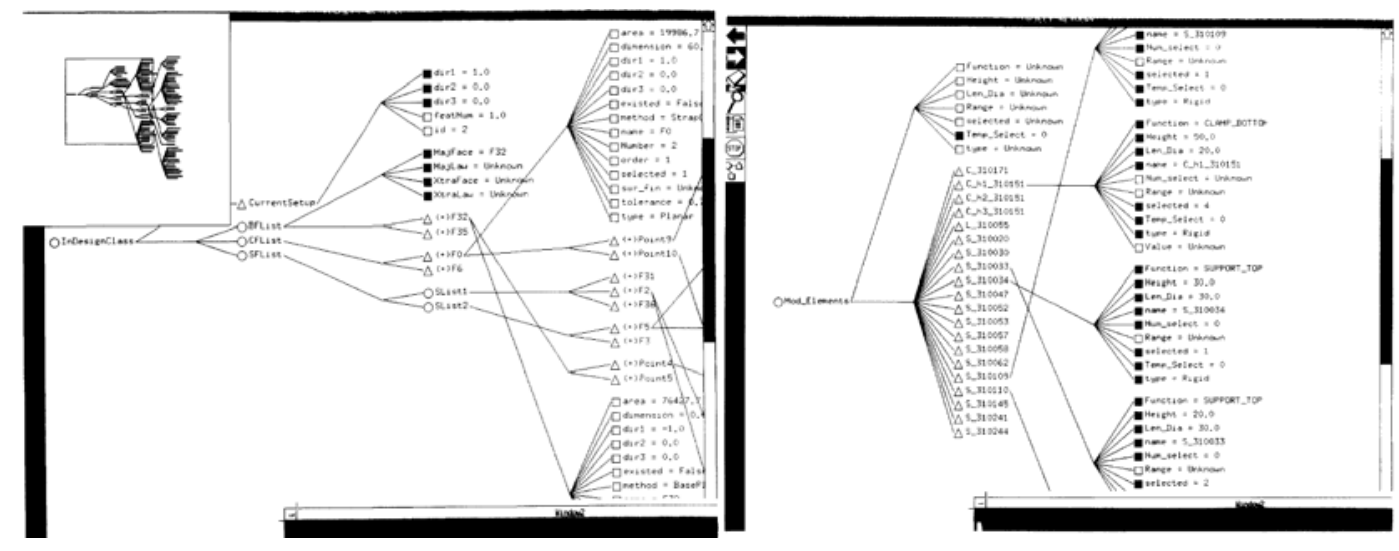

Slika 2.17. Grane semantičke mreže [33]

Znanje predstavljeno semantičkom mrežom može se shvatiti i kao skup iskaza koji opisuju te odnose. Par čvorova povezan relacijom može se posmatrati kao jednostavan iskaz, kao na primer [33]:

$$
\text { Vođica } \rightarrow j e \rightarrow \text { element za vođenje alata }
$$

U okviru reprezentacije znanja ključni koncept predstavlja relacija. Kod prikaza znanja o priborima primenom semantičkih mreža, relacija između objekata prikazuje se kao oznaka koja spaja ta dva objekta (vrha grafa). Relacija koja se ističe kao specifična relacija semantičkih mreža jeste "is-a“ relacija. Ova relacija definiše hijerarhijsku strukturu, te pripadnost objekta (instance) klasi. Relacija „is-a“ predstavlja koncept „biti instanca od“. Koristi se za povezivanje pojedinačnih objekata u klasu i iskazivanje pripadnosti instance klasi. Klasa se kao apstraktni koncept može uporediti sa matematičkim skupom, s tim da elementi klase moraju imati neka zajednička svojstva što za elemente skupa nije uslov. Ponekad se i pripadnost klase potklasi označava sa „is-a“. Uvodi se i relacija "has-a property“ (ima svojstvo) - kojom se opisuju svojstva objekata u mreži [16, 33].

Trenutni podaci u radnoj memoriji sa kojima rade neki ekspertski sistemi čija je baza znanja predstavljena preko semantičke mreže su konkretni objekti, u ovom slučaju elementi pribora i njihove proste relacije sa objektima 
definisanim u mreži (slika 2.18.). Od ekspertskog sistema zahteva se da izvede zaključak o nekim složenijim odnosima i osobinama datih objekata.

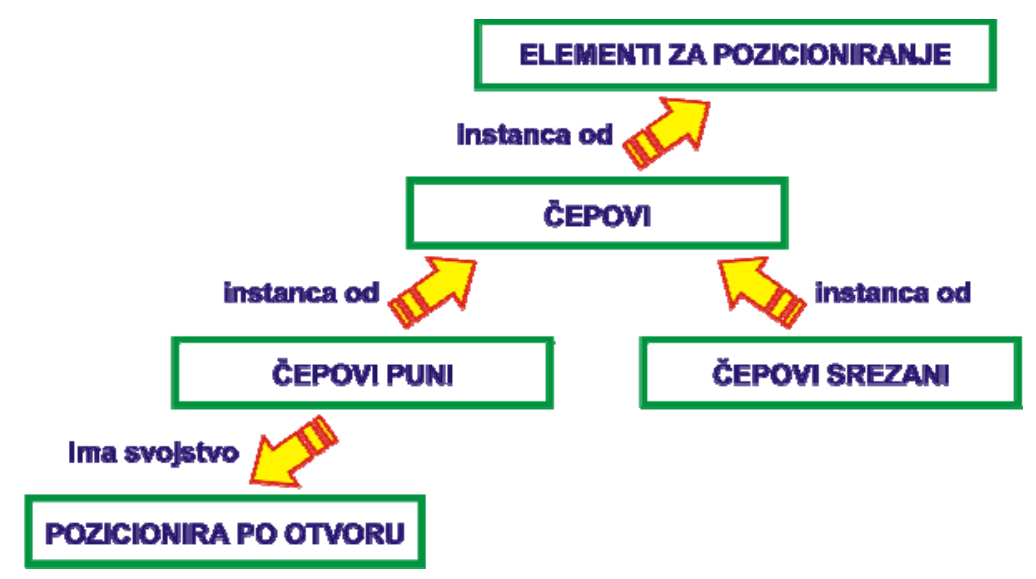

Slika 2.18. Segment semantičke mreže [122]

Osnovni problem ovog prilaza nastaje onda kada se dozvoli da jedan objekat pripada različitim klasama ili neke klase imaju različite natklase. Tada se može desiti da taj objekat (klasa) nasleđuje različita svojstva od različitih natklasa, a da su ta svojsva konfliktna (javlja se problem nasleđivanja).

\subsection{Okviri}

Okviri (ramovi) predstavljaju elemente za smeštanje informacija povezanih sa objektima. Pored toga, okviri sadrže pokazivače na druge okvire ili neke vrednosti. Okvir je kompleksna struktura pomoću koje se može predstaviti neki objekat - pribor ili element pribora. Svaki okvir pripada jednom objektu i sadrži proizvoljan broj označenih polja (slots) u koje se smeštaju činjenice od značaja za taj objekat, odnosno atributi koji predstavljaju karakteristične osobine pomoću kojih se opisuje posmatrani objekat. Svaki atribut ima niz svojstava (facts) kao što su, na primer, stvarna ili podrazumevana (default) vrednost atributa. Svojstvo atributa ne mora da bude samo neki epitet, već može da bude i proizvoljna procedura koja se izvršava pod određenim okolnostima (na primer, pri promeni vrednosti atributa). Polja mogu biti prazna ili mogu ukazivati na neki drugi okvir. Na taj način se skup okvira povezuje u mrežu okvira [119].

Okviri takođe mogu da sadrže podokvire (subframes) koji, pored svih atributa okvira u kojima se nalaze i koje od njih nasleđuju, mogu da imaju i neke specifične atribute. Podokviri, opet, mogu da imaju svoje podokvire itd. 
Podokviri su povezani sa nadređenim okvirima preko atributa „je(ste)“ ili „vrsta“. Okviri su pogodni za kodiranje one vrste znanja koja se odnosi na karakteristike pojedinih klasa i potklasa pojmova, odnosno objekata. Kao što se iz ovog kratkog opisa vidi, okviri omogućuju mešovito predstavljanje znanja, kombinujući deklarativne i proceduralne elemente u opisu nekog pojma ili objekta. Na slici 2.19. prikazana je šema primene okvira u predstavljanju znanja.

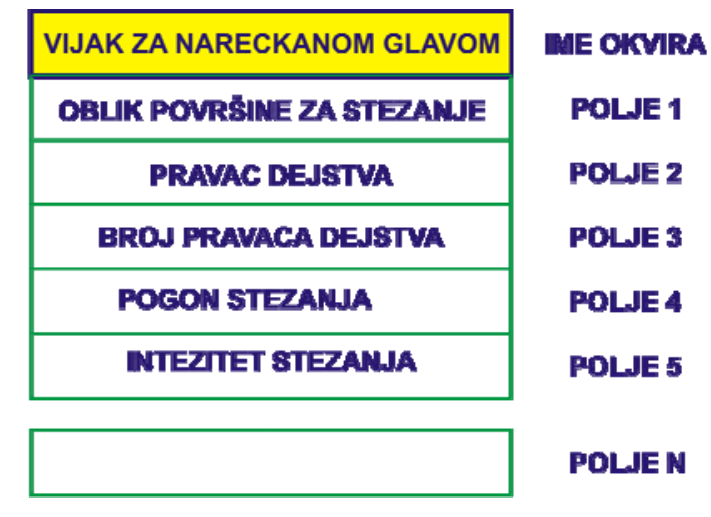

Slika 2.19. Predstavljanje znanja preko okvira [122]

Jezici koji koriste koncept okvira (frame based system) nazivaju se jezici okvira (frame based languages) i ubrajaju se u metajezike. Jezici okvira prvenstveno se koriste za prepoznavanje i opisivanje klasa objekata.

Svojstva karakteristična za sisteme okvira su [122]:

- Hijerarhijska organizacija (prema pravilima hijerarhije definisanim u okviru strategije nasleđivanja);

- Podređeni okviri - primerci (subframes) nasleđuju svojstva (vrednosti atributa) od nadređenih, generičkih, okvira (superframes) prema hijerarhijskoj organizaciji. Generički okviri se, dakle, nasleđuju.

Na slici 2.20. prikazan je primer generičkog okvira i okvira primeraka.

\begin{tabular}{|c|}
\hline VIJAK ZA NARECKANOM GLAVOM \\
\hline RAMMA \\
\hline UPRANAN \\
\hline JEDNN \\
\hline FUČNM \\
\hline 1500 N \\
\hline
\end{tabular}
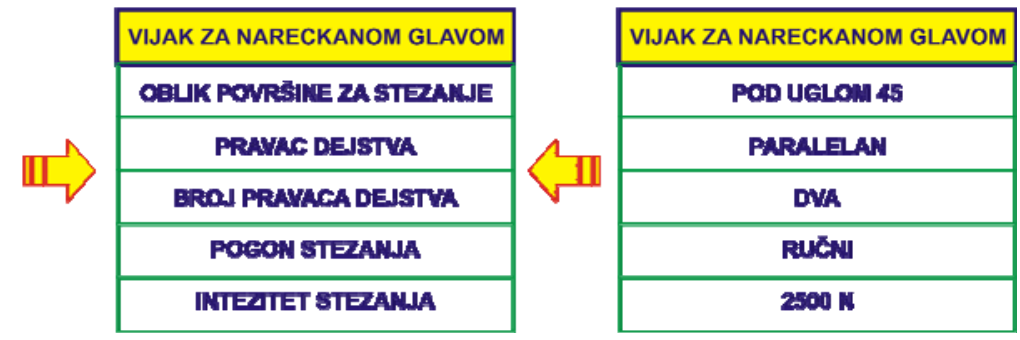

Slika 2.20. Primer generičkog okvira i okvira primeraka [122] 


\subsection{Mehanizam zaključivanja}

Mehanizam za zaključivanje ima zadatak da pronađe odgovarajuće znanje u bazi znanja ili da izradi novo znanje. Mehanizmi zaključivanja su locirani između baze znanja sa jedne strane i interfejsa prema korisniku sa druge strane. Pri tome izvršavaju dva osnovna zadatka, prvo, ispituju postojeće činjenice i pravila i dodaju nove kada je to moguće, i drugo, određuju redosled zaključivanja, sprovodeći na taj način konsultacije sa projektantom pribora. Proces zaključivanja predstavlja najvažniju aktivnost koja se odvija u ekspertnom sistemu. Zahvaljujući upravo ovom procesu, kaže se da su ekspertni sistemi programi koji se ponašaju „inteligentno“. Proces zaključivanja je taj koji „oživljava“ inače mrtvo znanje sadržano u bazi znanja i koji to znanje ume da primeni na postojeći problem. Bez procesa zaključivanja ekspertni sistem bi bio samo jedna enciklopedija, velika količina „mrtvog“ znanja o procesu projektovanja pribora, dok sa njim on postaje sličniji projektantu i mnogo primenljiviji u praksi. Mehanizam zaključivanja direktno komunicira sa bazom znanja, pa treba obezbediti efikasno i brzo pretraživanje podataka. Trivijalan način bio bi da se svako pravilo u bazi znanja uporedi sa svim podacima u radnoj memoriji, ali bi to trajalo dugo, osim u slučaju kada je broj pravila u bazi znanja mali. Zato se ovakav način izbegava i polazi od činjenice da je osnovna stvar $u$ inteligentnom rešavanju problema selektivno i efikasno dolaženje do rešenja na osnovu skupa mogućih alternativa. Interpretator obično koristi neku strategiju za efikasnije pretraživanje baze znanja i teži ispitivanju samo relevantnih pravila, onih za koja postoji jasna evidencija da barem delimično odgovaraju situaciji u radnoj memoriji. Korišćenje takvih strategija omogućuje da se u ranim fazama rešavanja problema iz skupa podataka u radnoj memoriji izdvoje oni najkorisniji i da se izbegne ispitivanje onih alternativa koje ne mogu da dovedu do pravog rešenja. Dve najpoznatije strategije tog tipa su ulančavanje unapred (forward chaining) i ulančavanje unazad (backward chaining) i svaka od njih se može realizovati primenom više različitih algoritama $[34,50,84,117]$.

\section{Ulančavanje unapred}

Ulančavanje unapred polazi od premisa, IF-delova pravila, i upoređuje ih sa podacima u memoriji računara. Time se utvrđuje koja su pravila zadovoljena - to su pravila čija je premisa nađena među podacima u memoriji. Pravila koja su zadovoljena mogu se realizovati tako da se njihovi THEN-delovi 
izvrše ukoliko su akcije, a ukoliko su iskazi, mogu se smatrati istinitim. Izvršavanje neke akcije menja stanje podataka u memoriji. Iskaz koji je istinit dodaje se već postojećim podacima u memoriji. Tako se dobija novo stanje podataka u memoriji računara. Sada se proverava da li je problem rešen, pa ukoliko jeste, o tome se obaveštava projektant pribora i sa radom se završava. Ukoliko rešenje nije nađeno, postupak se iterativno ponavlja. Ako se prilikom pretraživanja pravila u bazi znanja pokaže da nijedno pravilo nije zadovoljeno, ekspertni sistem zaključuje da nema dovoljno podataka da bi problem mogao da se reši. Tada sistem može ili da prekine sa radom ili da od projektanta pribora zahteva dodatne podatke. Ako dođe do konfliktne situacije, kada je zadovoljeno više pravila istovremeno, potrebno je odlučiti se za jedno koje će biti izvršeno. Pri tome, izbor se vrši najčešće na heuristički način $[34,50,84$, 117].

\section{Ulančavanje unazad}

Ulančavanje unazad je postupak obrnut od postupka ulančavanja unapred. U ovom postupku se polazi od zaključka, od THEN-dela pravila. Prvo se pretpostavi da neko od mogućih rešenja problema važi i ono se označi kao tekuća hipoteza. Zatim se pronalazi ono pravilo čiji THEN-deo predstavlja to rešenje. Potom se proverava da li pronađeno pravilo važi tako što se proverava da li važe sve premise (IF-delovi) tog pravila. Premisa za koju se proverava važnost označi se kao nova tekuća hipoteza. Ovaj postupak se rekurzivno ponavlja za svaku od premisa. Ako se tekuća hipoteza ne potvrdi, ona se odbacuje, vraća nazad i postavlja se nova tekuća hipoteza. Ovako se proveravaju sve premise svih tekućih hipoteza. Ukoliko se ne potvrdi nijedno od rešenja, ekspertni sistem može da traži dodatne informacije od projektanta pribora $[50,84]$.

\subsubsection{Primena zaključivanja na osnovu slučaja u projektovanju pribora}

Jedan od pristupa u inteligentnom projektovanju pribora je zaključivanje na osnovu slučajeva kada se projektovanje novih konstrukcija pribora bazira na prethodnim rešenjima, pa se svakoj novoj fazi projektovanja pristupa sa iskustvom [13]. Ovakav koncept rešava nove probleme u projektovanju pribora 
koristeći rešenja postojećih konstrukcija pribora, odnosno koristi i adaptira rešenja pređašnjih problema [12].

Proces zaključivanja na osnovu slučajeva teče tokom koji je dalje izložen. Kada se javi novi problem koji treba rešiti, tj. novi radni predmet za koji je potrebno projektovati pribor, projektant pretražuje tzv. bazu znanja da bi našao konstruktivna rešenja pribora koja su slična. Zatim se postojeće rešenje pribora prilagođava novim zahtevima i generiše se novo rešenje. Ako se dva puta rešava isti problem $u$ istom kontekstu (svi parametri isti ili "dovoljno“ slični), pamti se rešenje koje na bolji način rešava problem [1, 89]. Ovim se postiže unapređivanje procesa odlučivanja u konkretnom slučaju (slika 2.21.).
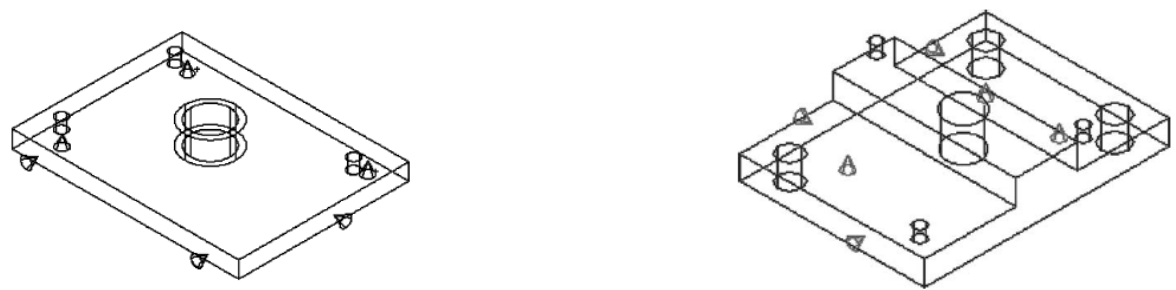

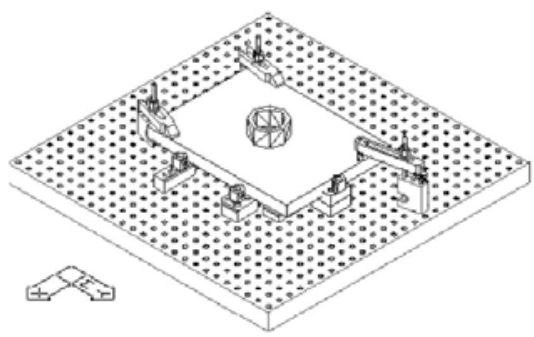

postojeće rešenje

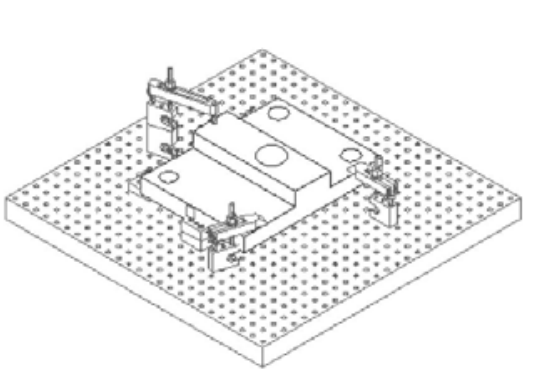

novo rešenje

Slika 2.21. Primer postojećeg pribora i novokonstruisanog upotrebom sistema zaključivanja zasnovanog na slučajevima [97]

Zaključivanje na osnovu slučajeva (slika 2.22.) sastoji se iz šest aktivnosti [1, 89]:

- pronalaženja znanja ${ }^{8}$, odnosno slučaja koji odgovara problemu' ${ }^{9}$,

- korišćenja dela pronađenog znanja za rešavanje problema,

- prilagođavanja dela pronađenog znanja novom problemu, ukoliko ima potrebe,

- proveravanja da li je novo rešenje vredno pamćenja,

\footnotetext{
8 Termin „znanje“ se odnosi na raspoloživo znanje pri projektovanju pribora.

${ }^{9}$ Termin „,problem“ se odnosi na problem projektovanja novog konstruktivnog rešenja pribora. 
- pamćenja novog znanja, ukoliko je tako odlučeno u prethodnoj aktivnosti,

- prerade „novog“ znanja u bazi znanja, ukoliko za tim ima potrebe.

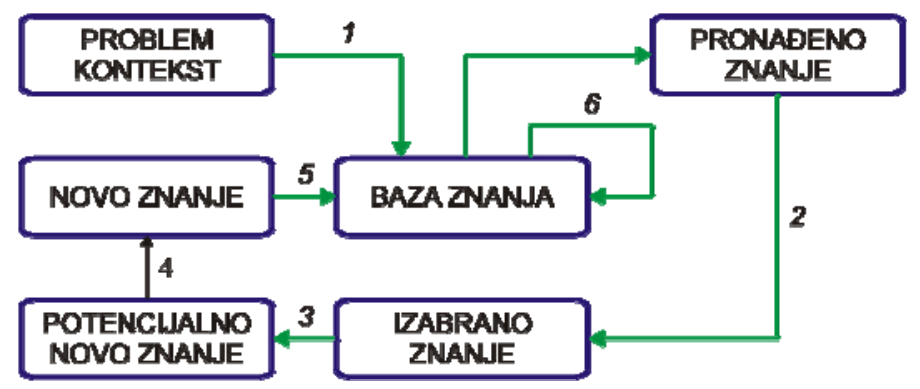

Slika 2.22. Strukturna šema zaključivanja na osnovu slučaja [1, 89]

Šest aktivnosti zaključivanja na osnovu slučaja mogu da se grupišu u četiri faze odlučivanja, a to su [152, 222]:

1. strukturiranje problema,

2. normalizacija podataka,

3. agregacija podataka,

4. analiza.

Kod zaključivanja na osnovu slučaja potrebno je da se problem uredi, da se struktuira. Problem projektovanja pribora uređuje se preko tzv. slučajeva $[26,28]$. Pošto nije lako pamtiti ceo slučaj, kao veliku količinu neuređenog teksta, problem se rastavlja na potprobleme, tj. kriterijume. Time slučaj dobija svoju strukturu. Svaki slučaj sadrži kriterijume koji su podeljeni na ulazne i izlazne kriterijume. Ulazni kriterijumi pamte problem dok izlazni kriterijumi pamte rešenje problema. Slučaj se, prema tome, sastoji od skupa kriterijuma čije vrednosti nose informacije o problemu i skupa kriterijuma koji nose informacije o njegovom rešenju. Podskup skupa kriterijuma koji služe za pretraživanje baze znanja su indeksi. Svaki slučaj se sastoji iz tzv. indeksiranih i neindeksiranih kriterijuma. Indeksirani kriterijumi služe za pretraživanje baze znanja. Neindeksirani kriterijumi služe za opisivanje slučaja i mogu uticati na rešenje problema ukoliko indeksirani kriterijumi ne sadrže dovoljno informacija. Neindeksirani kriterijumi ne služe za upoređivanje slučajeva (nisu normalizovani), jer u sebi nose semantičke informacije neprikladne za normalizaciju (npr. grafički podaci o priborima). Indeksi, tj. kriterijumi za pretraživanje, trebalo bi da prema [27, 85, 210] budu: razumljivi, svrsishodni, dovoljno apstraktni (radi eventualnog proširivanja baze slučajeva) i konkretni kako bi pretraživanje bilo precizno (tabela 2.1.). 


\begin{tabular}{|c|}
\hline Indeksirani kriterijumi \\
\hline Površina za obradu \\
\hline Oblik radnog predmeta \\
\hline Pravac obrade \\
\hline Veličina radnog predmeta \\
\hline Materijal radnog predmeta \\
\hline Centar gravitacije radnog predmeta \\
\hline Tolerancije radnog predmeta \\
\hline
\end{tabular}

Tabela 2.1. Indeksiranje slučajeva [85]

$\mathrm{Na}$ slici 2.23. prikazana je šema indeksiranja kriterijuma u vidu stabla dok je na slici 2.24 prikazanao indeksiranje kriterijuma u obliku dekompozicije pozicioniranja.

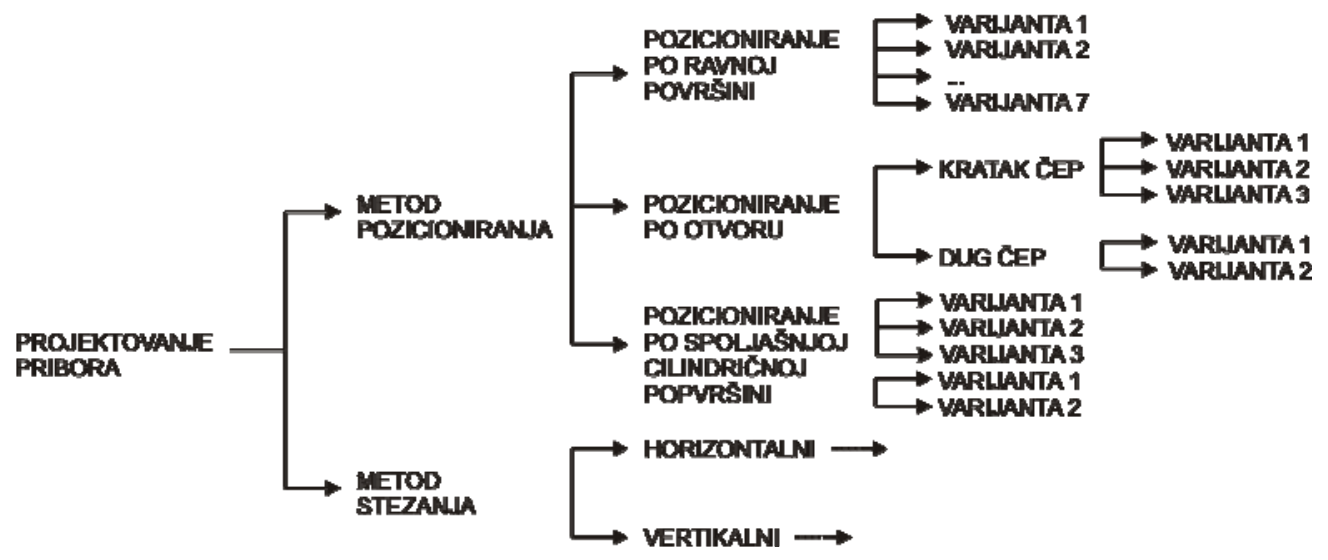

Slika 2.23. Indeksiranje kriterijuma u vidu stabla [12]

Izbor indeksa (indeksiranje) može da se sprovede ručno ili automatski. Ručni metod zahteva ekpertsko znanje. Automatske metode mogu biti [172, 189, 210]:

- kriterijumske - identifikuju indekse koji najviše utiču na rešenje;

- zasnovane na razlikama - za svaki slučaj se kao indeks bira ona vrednost kriterijuma koja najbolje diferencira slučaj od ostalih slučajeva, a slučaj se prepoznaje po svojim ekstremnim vrednostima;

- zasnovane na sličnostima - generiše se određeni skup kriterijuma za definisanje apstraktnih slučajeva, pojedinačni slučajevi dobijaju opšte kriterijume skupa kome pripadaju dok se slučaj diferencira dodavanjem kriterijuma koji ne pripadaju opštim kriterijumima;

- induktivne metode učenja - koriste kao indekse kriterijume iz kojih mogu da se izvuku neka opšta pravila (koriste se samo bitni kriterijumi 
za opisivanje nekog slučaja, a metode koje se koriste su ID3, C4.5, C5.0).

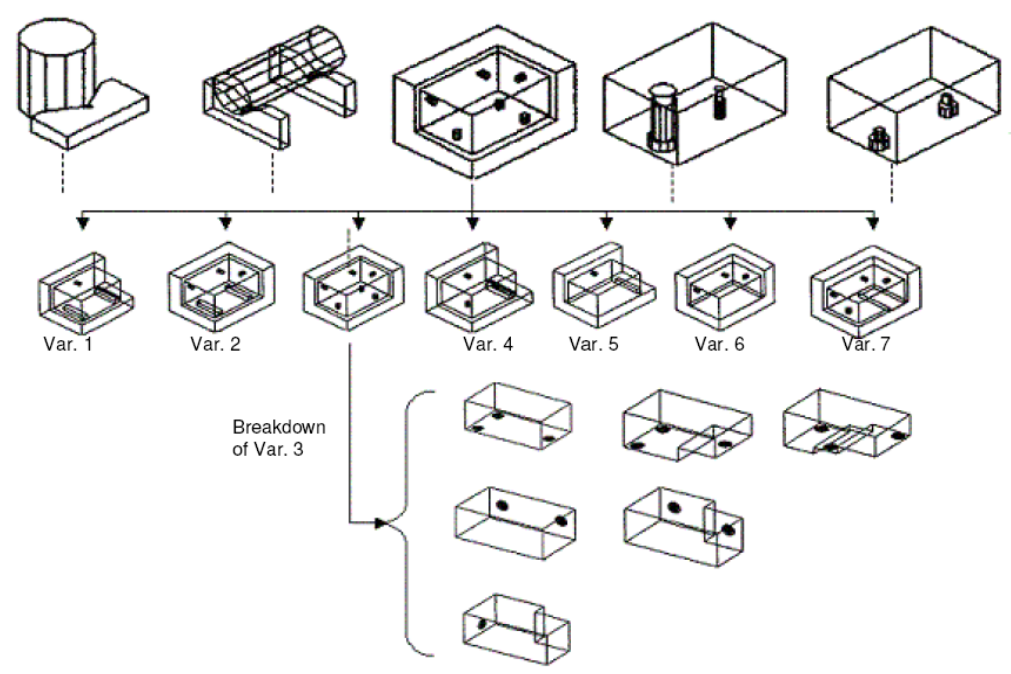

Slika 2.24. Indeksiranje kriterijuma - dekompozicija pozicioniranja [13]

Nakon što je slučaj strukturiran, potrebno je sve podatke dovesti u oblik koji omogućava da se njima efikasno upravlja. Kod normalizacije je sve slučajeve potrebno organizovati tako da sve vrednosti budu uporedive. Normalizacija može imati i šire značenje. Može se posmatrati kao proces u kojem se određenom skupu podataka dodeljuje zajedničko obeležje da bi se lakše upravljalo podacima o priborima i elementima pribora [13, 28]. Svaki način organizovanja podataka koji obezbeđuje poređenje i upravljanje podacima nosi u sebi obeležja normalizacije. Najpoznatiji modeli za uređivanje podataka su [97, 174, 199, 210]:

- dinamički memorijski model,

- model kategorijskih uzoraka.

Baza slučajeva se sastoji od ramova znanja (tabele odlučivanja) koji su osnovna jedinica dinamičke memorije. Razlikuju se dve vrste formi: instance (predstavljaju slučajeve) [13] i apstrakcije (predstavljaju instance) [199].

Nakon što su izvršene analiza i normalizacija, moguće je izvršiti sintezu podataka, tj. agregaciju. Kod zaključivanja na bazi slučajeva koristi se koncept sličnosti (udaljenosti) kojim se računa odstojanje novog pribora od postojećih rešenja pribora. Najpoznatije metode koje se koriste za pronalaženje slučajeva su: metoda najbližeg suseda, indukcija, indukcija vođena znanjem i otkrivanje paterna [1]. Ove metode mogu biti samostalne ili kombinovane u tzv. hibridne 
strategije pronalaženja. Sve metode pretraživanja pretvaraju više indeksa u jednu vrednost (kolonu) na osnovu koje se vrši sortiranje i izbor najbližeg slučaja - adekvatne konstrukcije pribora.

Metoda „najbližeg suseda“ za računanje sličnosti između novog pribora i postojećih konstrukcija pribora određuje sličnost postojećeg pribora sa novim na osnovu težinskog zbira indeksa. Najveći problem kod ove metode su određivanje težina i sporost pronalaženja potrebnog rešenja. Brzina metode je linearno zavisna od broja slučajeva u bazi znanja [97].

Algoritam „indukcije“ je pogodan kada se sličnost može izmeriti na osnovu pravila tipa If-Then. Osnovna podloga za proces indukcije je prethodno generisanje tipskih konstrukcija pribora, koje se po određenoj logici zaključivanja prilagođavaju konretnoj operaciji obrade na radnom predmetu čime se dobija radna (finalna) konfiguracija pribora (slika 2.25) [12, 13, 189].

\begin{tabular}{|c|}
\hline Ako je (primarna površina za pozicioniranje „ravna“) \\
Onda je (konceptualno rešenje pozicioniranja „ravan“) \\
Ako je (primarna površina za pozicioniranje „otvor“) \\
Onda je (konceptualno rešenje pozicioniranja pun čep) \\
Ako je (primarna površina za pozicioniranje „cilindrična“) \\
Onda je (konceptualno rešenje pozicioniranja „spoljašnja prizma“)
\end{tabular}

Slika 2.25. Primena IF-Then pravila za merenje sličnosti

Nakon što je izvršen proces otkrivanja slučaja ili slučajeva, treba proveriti mogućnost primene starog rešenja pribora na novi problem. Kod zaključivanja na osnovu slučaja, u tu svrhu postoje mehanizmi koji prilagođavaju staro rešenje novom problemu. Prilagođavanje se zasniva na uočavanju bitnih razlika između starog i novog rešenja i izmenama starog rešenja da bi se odgovorilo zahtevima novog. Uopšteno, postoje dve vrste prilagođavanja [89]:

- Strukturalno prilagođavanje ili prilagođavanje starog rešenja (slučaja) novom problemu (novom slučaju), gde postoje precizno definisana pravila kojih se projektant pribora pridržava;

- Derivaciono prilagođavanje, koje koristi algoritme, metode ili pravila koja su generisala originalno rešenje da bi rešilo novi problem. Kod ovog pristupa plan konstrukcije pribora treba biti upamćen zajedno sa priborom. Ovaj pristup može se koristiti samo ukoliko je problem poznat, tj. strukturiran. 
Skup pravila koja služe za prilagođavanje slučajeva novim zahtevima trebalo bi da bude dovoljno obuhvaćen, a istovremeno bi trebalo da budu zastupljena i pravila strukturalne adaptacije da bi se prilagodila slabo shvatljiva rešenja i mehanizmi derivacije (nasleđivanja) koji će se koristiti kod slučajeva koji su dobro shvatljivi. Za adaptaciju je moguće koristiti $[89,173,199]$ :

- Nultu adaptaciju. To je najjednostavnija metoda jer ne vrši nikakvu adaptaciju. Projektant pribora dobija slučajeve sortirane po sličnosti sa novim problemom.

- Parametarsko usklađivanje. To je adaptivna tehnika koja upoređuje specifične parametre otkrivenog i novog rešenja da bi modifikovala rešenje u skladu sa preciznim pravilima.

Tehnike adaptacije mogu da pomognu da se sagleda da li je slučaj dobro strukturiran, da li je izvršena kvalitetna normalizacija, da li je agregacija urađena korektno. Ova tehnika omogućava da se postojeća baza slučajeva efikasnije iskoristi za rešavanje novih konstrukcija pribora.

\subsubsection{Primena neuronskih mreža u projektovanju pribora}

Neuronske mreže predstavljaju prelazak sa simboličkog na podsimbolički nivo obrade informacija. Pri tome se značenje pojmova ne daje svesno i nisu u potpunosti poznata pravila koja mogu dovesti u vezu ulazne informacije i željeni izlaz iz sistema - konstrukciju pribora.

Bitna razlika u odnosu na klasične računare je da se neuronske mreže ne „programiraju“. Dok kod klasičnog računara programer u računar unosi program kojim se tačno specificira rad računara u svakom trenutku, neuronske mreže se ne programiraju, već „obučavaju“. Pre nego što počnu da se primenjuju, ulaže se dosta vremena u njihovo obučavanje, učenje ili treniranje. Proces obučavanja se zasniva na ažuriranju najčešće težinskih koeficijenata veza, a ponekad samo vrednosti ulaznih procesorskih jedinica. Težinski koeficijenti veza ili težine veza su koeficijenti koji su dodeljeni vezama neuronske mreže u svakom trenutku $[9,63,101]$.

U ovom prilazu nema potrebe za eksplicitnom formulacijom znanja od strane projektanta. Neuronske mreže se obučavaju tokom vremena. Bitno je definisati sistem i veze unutar njega. Neuronsku mrežu čini jedan ulazni, jedan izlazni i jedan ili više skrivenih slojeva, pri čemu svaki od njih ima određeni broj neurona (slika 2.26). 


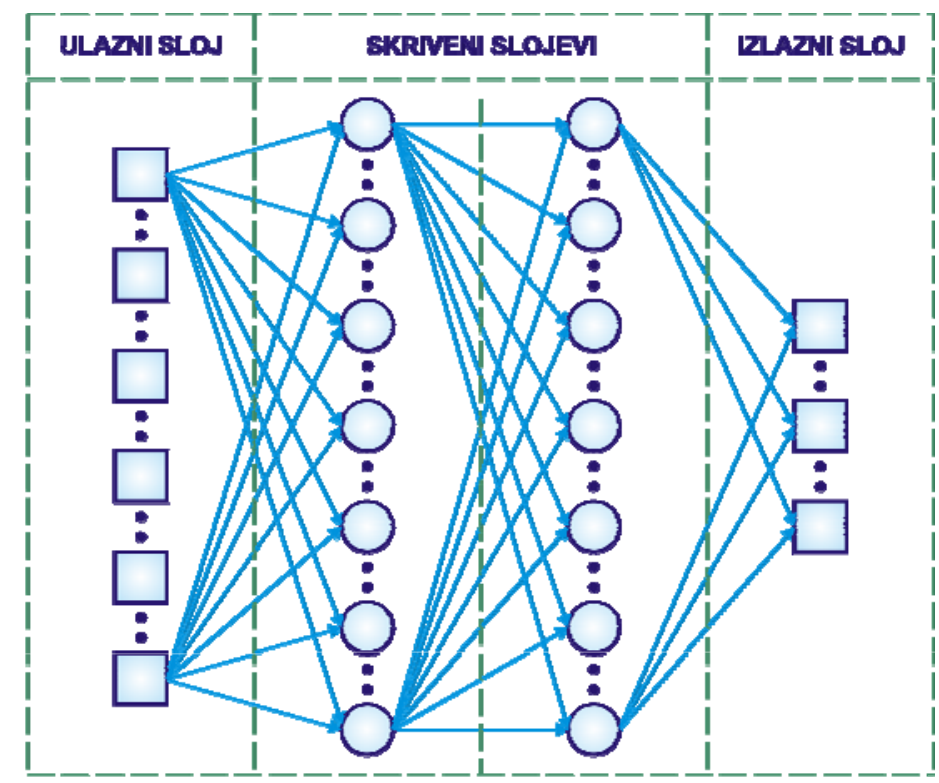

Slika 2.26. Opšta struktura neuronske mreže sa dva skrivena slojem

Proces obučavanja neuronskih mreža započinje zadavanjem slučajnih vrednosti težinskih koeficijenata veza i dovođenjem oblika na ulazni sloj. Zatim se mreža aktivira i upoređuju se izlazni i zadati oblik (zahtevani oblik, onaj koji treba da se dobije). Obučavanje se vrši tako da se ažuriraju težinski koeficijenti sa ciljem da se u sledećoj iteraciji dobije izlaz koji je bliži zadatoj vrednosti. U trenutku kad se postigne zadovoljavajući rezultat sa jednim ulaznim oblikom, na ulaz se dovodi drugi itd. Kad se završi sa svim oblicima iz obučavajućeg skupa, na ulaz mreže se ponovo dovodi prvi ulazni oblik. Ova se procedura nastavlja sve dotle dok se ne dođe do zadovoljavajućih rezultata za sve oblike iz obučavajućeg skupa. Kad je obučavanje mreže jednom završeno, težinski koeficijenti veza ostaju nepromenjeni. Tek tada, posle obučavanja, mreža se može primeniti za projektovanje pribora [31, 153, 231].

Ulazni sloj se sastoji od ulaznih procesorskih jedinica. Svakoj jedinici se dodeljuje određena vrednost $u$ zavisnosti od vrednosti pojedinih elemenata niza koji predstavlja ulazni oblik. Sa svojih izlaza, ove procesorske jedinice prosleđuju signale do sledećeg sloja prema strukturi date mreže. Svi ulazi u neuronsku mrežu korespondiraju sa jednim atributom radnog predmeta ili tehnoloških informacija neophodnih za ispravno projektovanje pribora [63, 153]. Kvalitativni atributi se najpre procesiraju na numeričke ekvivalencije pošto je ulaz u mrežu numerička vrednost atributa. Važan početni korak je pravljenje pogodnog sistema kodiranja ulaznih informacija kako bi se informacija mogla predstaviti neuronskoj mreži. Primeri informacija koje ulaze u neuronsku mrežu dati su u tabeli 2.2. 


\begin{tabular}{|l|c|c|}
\hline \hline \multicolumn{1}{|c|}{ Ulaz } & Varijanta & Kod \\
\hline \hline Veličina serije & srednja & 2 \\
\hline Brzina obrtanja glavnog vretena & velika & 3 \\
\hline Operacija & bušenje & 2 \\
\hline Visina radnog predmeta & mala & 1 \\
\hline Veličina radnog predmeta & srednja & 2 \\
\hline Prethodno obrađene površine & stepenica & 2 \\
\hline Oblik primarne površine za pozicioniranje & ravan & 1 \\
\hline Oblik sekundarne površine za pozicioniranje & ravan & 1 \\
\hline Oblik tercijarne površine za pozicioniranje & ravan & 1 \\
\hline
\end{tabular}

Tabela 2.2. Ulazne informacije u ulaznom sloju neuronske mreže [169]

Izlazni sloj procesorskih jedinica na svojim izlazima daje vrednosti koje se koriste kao izlazni oblici. Izlaz iz mreže predstavlja rešenje problema konstrukcije pribora. $U$ studijama koje su se bavile problematikom projektovanja pribora, izlaz iz mreže nije gotova konstrukcija pribora niti elementi od kojih treba sastaviti pribor, već smernice za projektovanje pribora (slika 2.27. i tabela 2.2). Primer izlaznih rezultata prikazan je u tabeli 2.3.

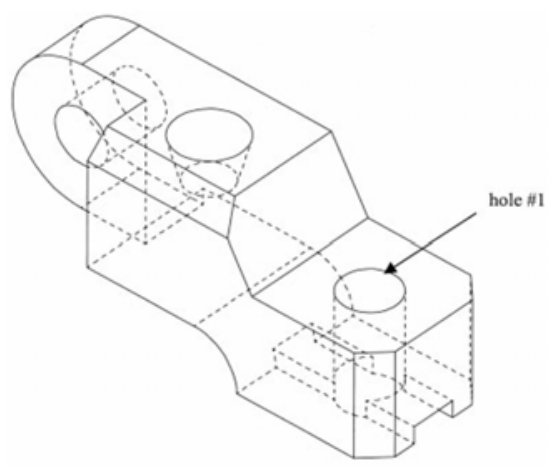

Slika 2.27. Radni predmet za koji je potrebno projektovati pribor [169]

\begin{tabular}{|l|c|c|}
\hline \multicolumn{1}{|c|}{ Komponente } & Projektant - ekspert & Neuronska mreža \\
\hline Primarno pozicioniranje & tri tačke & ravna površina sa žlebom \\
\hline Sekundarno pozicioniranje & ravna površina & ravna površina \\
\hline Tercijarno pozicioniranje & ravna površina & ravna površina \\
\hline Broj pravaca stezanja & dva & dva \\
\hline Tip stezanja & polužni & polužni \\
\hline Pogon stezanja & ručni & ručni \\
\hline Telo pribora & standardni elementi & zavarena konstrukcija \\
\hline
\end{tabular}

Tabela 2.3. Primer izlaznih rezultata iz sistema baziranih na neuronskim mrežama [169] 


\subsubsection{Ostala istraživanja u području automatizovanog projektovanja pribora}

Kako su se sistemi za projektovanje pribora razvijali, tako se i pažnja mnogih istraživača sve više usmeravala na optimizaciju konstrukcije pribora uz podršku informacionih tehnologija. Za optimizaciju sistema radni predmetpribor najčešće su se upotrebljavali numerički proračuni koji se izvode tzv. metodom konačnih elemenata (MKE), poznatom još i kao FEM (Finite Element Method) ili FEA (Finite Element Analysis).

Projektovanje u CAD programima podrazumeva više iteracija, pa tako projektant može da izmodelira deo u CAD programu i odmah izvede neke osnovne provere pomoću FEM-a. Tako se brzo uočava šta treba promeniti u konstrukciji, pa se kroz nekoliko uzastopnih koraka modeliranja $i$ ispitivanja dolazi do preliminarnog rešenja $[19,137]$. Osnovni pristup MKE u analizi pojedinih elemenata je da se analizom delova zaključuje o celini. Poznati je induktivni pristup koji se primenjuje u mnogim područjima nauke.

Ukoliko se želi dobiti „precizna“ slika onoga što će se dešavati kada se radni predmet nađe pod opterećenjem, svaka tačka modela mora se posmatrati ponaosob. Utvrđivanjem zakonitosti ponašanja tačaka i njihovih međusobnih interakcija za zadata opterećenja određuje se ponašanje radnog predmeta. Ako se žrtvuje egzaktnost zarad praktičnosti, radni predmet se može izdeliti na konačan broj malih delova $i$ onda se može sprovesti izračunavanje za svaki od njih. Prelaskom iz fizičkog u matematički domen, čitav proces se svodi na komplikovan, ali i rešiv sistem jednačina. Na primer, ako je model radnog predeta izdeljen na 100.000 elemenata, što je realna vrednost u praksi, metodom konačnih elemenata rešavaće se sistem od oko 100.000 jednačina sa 100.000 nepoznatih. Rešavanje bi bilo praktično neizvodivo bez upotrebe računara, ali uz njegovu procesorsku moć može se doći do rezultata. Uz pažljivo odabran broj i raspored konačnih elemenata mogu se dobiti dragoceni podaci o ponašanju radnog predmeta sa zadovoljavajućom tačnošću. Za radni predmet se prvo definišu opterećenja (sile i momenti rezanja) u željenim tačkama, postave granični uslovi i podaci o oslanjanju radnog predmeta (tačke oslonca), a zatim pristupa postavljanju mreže [38, 39, 93, 94, 105, 209, 227]. Mreža je zapravo način na koji model biva izdeljen na male konačne elemente, a to je posao koji zavisi od znanja $\mathrm{i}$ iskustva projektanta $[145,164]$. Postavljanje mreže se najčešće obavlja kroz iteracije - prvo se postavlja retka mreža, a kad rezultat pokaže kritične tačke, ti delovi se premreže finijom strukturom i proračun se ponavlja [39, 209, 225]. Iskusan projektant pribora unapred može da predvidi poziciju kritičnih mesta. 
Domen rešavanja se podeli na određeni broj diskretnih ili konačnih elemenata; za dvodimenzionalne probleme obično se koriste trougaoni ili četvorougaoni elementi dok se za trodimenzionalne probleme najcešce koriste tetraedri i heksaedri (slika 2.28) [123].

Kod najjednostavnijih metoda konačnih elemenata, rešenje se aproksimira funkcijom linearnog oblika unutar svakog elementa, na način koji garantuje kontinuitet rešenja preko granica elemenata. Ova aproksimacija se zatim zameni u težinski integral zakona održanja, pa se kao rezultat dobiju nelinearne algebarske jednačine. Osnovna prednost metode konačnih elemenata je sposobnost da rešava probleme sa različitom, ponekad vrlo kompleksnom geometrijom. Ove metode se vrlo lako analiziraju matematički. $\mathrm{Na}$ kraju preostaje da se zadaju fizičke karakteristike materijala od kojeg će proizvod biti napravljen. Nizom iteracija kroz MKE program dolazi se do rešenja. Što je mreža gušća, to je proračun precizniji, ali je i vreme obrade duže. Nije retkost da obrada traje satima, čak i danima, zato je uz MKE za analizu pogodno koristiti još neke alate i tehnike [38, 39].

Nakon što je problem u potpunosti postavljen, na scenu stupa solver program koji obavlja izračunavanja i vraća rezultate. Rezultati analize ukazuju na eventualne probleme, pa se u CAD programu mogu izvršiti potrebne izmene. $U$ tom slučaju, ceo postupak se ponavlja onoliko puta koliko je potrebno da bi se dobilo zadovoljavajuće rešenje. I-DEAS je veoma popularan u projektovanju jer se smatra za najkvalitetniji program za postavljanje mreža, a pored toga je u potpunosti nezavisan, kako prema CAD aplikaciji iz koje preuzima model, tako i prema solveru kome predaje podatke [82, 159, 208]. $\mathrm{Niz}$ iteracija kojima se kroz CAD/CAE program dolazi do rešenja ima za cilj da završni model bude što funkcionalniji. Na primer, ako je u nekom sklopu potrebno odrediti dimenzije rebara za ojačanje koje treba da izdrži neko opterećenje, to se može izvesti na dva načina. Prvi pristup podrazumeva upotrebu dovoljno masivnog rebra koje će sigurno izdržati, a drugi provlačenje modela kroz CAE kako bi se odredile one dimenzije koje izdržavaju zahtevano opterećenje, ali ne i opterećenje koje je bitno veće. Ovo je značajno ako se projektovani pribor izrađuje u velikim serijama, jer može znatno da utiče na cenu.

Metod konačnih elemenata nametnuo se pošto se potvrdio u opštoj primeni, čak i kod najkomplikovanijih problema (kako linearnih, tako i fizički i geometrijski nelinearnih, kao i kod multifizikalnih problema). Jezgro MKE je pritom svođenje mehaničkih izlaznih problema na rešavanje sistema linearnih, odnosno nelinearnih jednačina. Pomoću razvijenih softvera za proračun, 
danas je na računaru moguće prilično pouzdano simulirati fizičko/mehaničko ponašanje sistema.
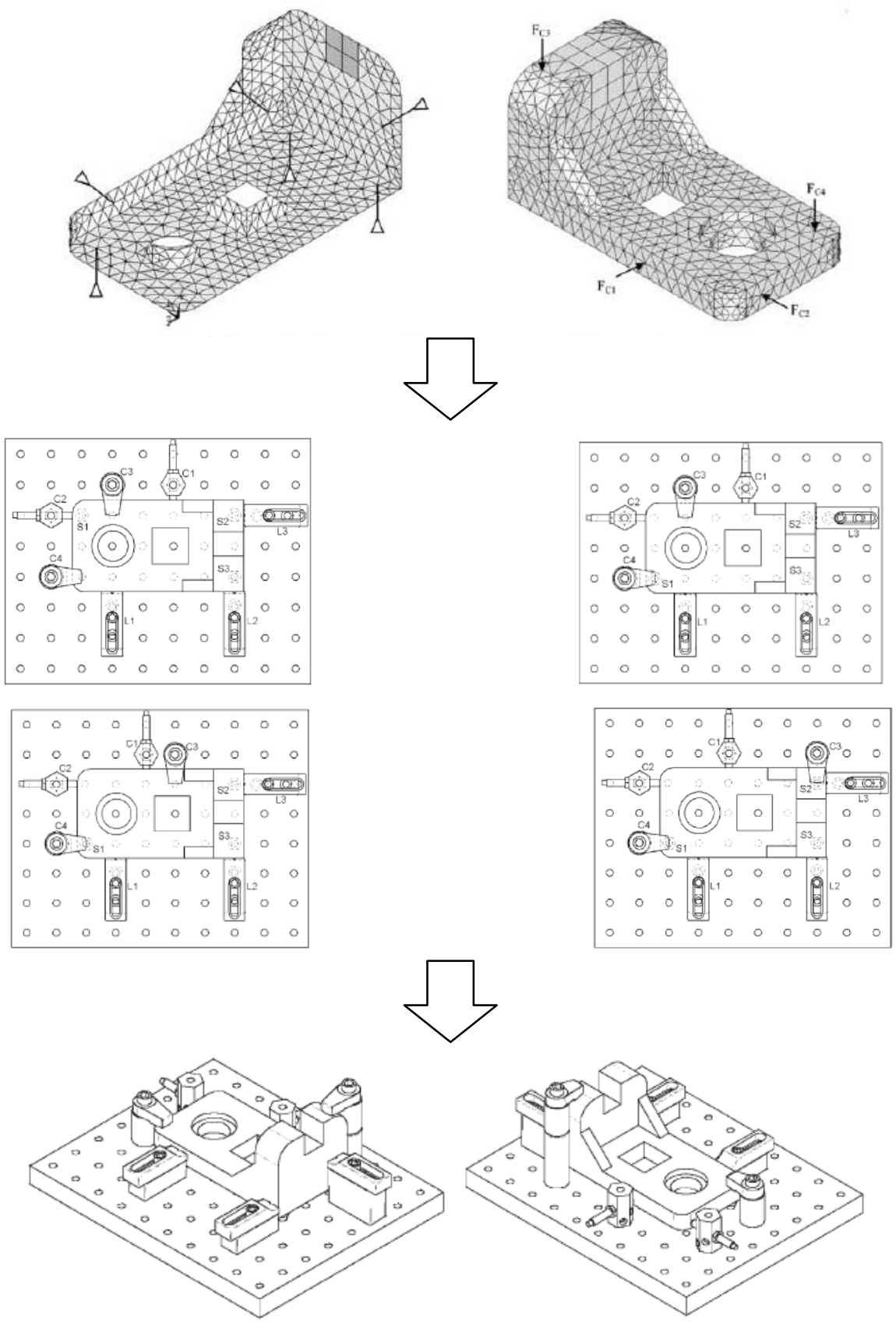

Slika 2.28. Primena MKE u optimizaciji konstrukcije pribora [82]

Treba naglasiti da MKE ne rešava problem konstrukcije pribora, već samo pomaže projektantu da odredi pogodna mesta za postavljanje elemenata za prozicioniranje ili stezanje - determiniše pozicije elemenata za pozicioniranje ili stezanje. Zajednička karakteristika svih dosadašnjih istraživanja jeste da je model radnog predmeta posmatran kao kruto telo [19, 
$36,38,39,82,93,94,104,106,137,145,159,164,208,209,225,226,227]$. $U$ većini istraživanja, trenje koje nastaje između elemenata pribora i radnog predmeta se zanemaruje. Materijali radnog predmeta su različiti. Neka istraživanja se bave problematikom analize deformacija radnih predmeta pod varijantnim opterećenjem i određivanjem minimalne i maksimalne sile stezanja koja će obezbediti zahtevanu tačnost izrade $[94,137,208,226]$. Sa druge strane, čest je slučaj minimizacija superpozicije pomeranja u čvorovima u posebnim tačkama na obrađivanoj površini $[159,164,227]$. Nelinearne tehnike optimizacije i heuristički postupci korišćeni su za određivanje statički stabilne konfiguracije pribora [38, 39]. Umesto brojeva čvorova (MKE), korišćeni su i konstruktivni parametri radnog predmeta, tj. rastojanja od referentnih ivica $[104,105]$. Problematika je prilično pojednostavljena pošto su neka istraživanja izvršena na dvodimenzionalnim radnim predmetima [123]. U nekim slučajevima razvijani su modeli za predviđanje minimalnih sila stezanja, koji uzimaju u obzir kontaktnu deformaciju radnog predmeta na mestu dejstva elementa za stezanje $[40,123]$. Eksperimentalni rezultati istakli su značaj koji elastičnost pribora ima za ponašanje sistema radni predmet-pribor pod opterećenjem usled obrade. Razmatrane su i pozicije elemenata za pozicioniranje i stezanje izvođenjem analize stabilnosti na osnovu proširene teorije vijka (screw theory) $[4,156]$, kao i primenom postupaka uravnoteženja sila $[2,177]$. Primenom gore pomenutih metoda moguće je u manjoj ili većoj meri izvesti optimizaciju položaja elemenata za pozicioniranje i/ili stezanje. 


\section{3}

\section{KRITIČKI OSVRT NA DOSADAŠNJA ISTRAŽIVANJA I DEFINISANJE CILJA RADA}

\subsection{GLOBALNE KARAKTERISTIKE RAZVIJENIH SISTEMA}

U protekle dve decenije mnogo je naučnika uložilo veliki napor kako bi se proces projektovanja pribora racionalizovao, tj. automatizovao. Brojni su primeri razvijenih sistema. Istraživanja literaturnih informacija, lični kontakti i prepiske autora sa stručnjacima i naučnicima iz posmatranog područja pokazali su da je do sada postojalo nekoliko pravaca (prilaza) u automatizaciji projektovanja pribora, a čine ih:

- konvencionalni programi,

- ekspertski sistemi,

- sistemi zaključivanja na osnovu slučaja,

- sistemi neuronskih mreža.

Konvencionalne programe karakteriše klasično algoritamsko programiranje. Ovi programi uglavnom se upotrebljavaju za obradu prema jasnim i tačno definisanim algoritmima koji, korak po korak, vode sistem ka parcijalnom rešenju konstrukcije pribora. Ukoliko program po svojoj semantici odgovara postavljenom problemu i ukoliko su ulazni podaci tačni, konvencionalni program će rezultirati tačnim rešenjem postavljenog problema. Konvencionalni programi rade na način koji je najčešće samo programerima razumljiv. Konvencijalno programiranje se odvija sekvencijalno (iterativno) u tri faze, a to su: projektovanje, kodiranje i provera/otklanjanje grešaka. U konvencionalnim obradama podataka proceduralno znanje je u programima, a 
deklarativno u podacima smeštenim u datotekama ili bazama podataka. Kao opšte karakteristike razvijenih sistema za automatizovano projektovanje pribora, zasnovanih na klasičnom (konvencionalnom) programiranju, mogu se izdvojiti sledeće:

- projektovani su za tačno određene geometrijske oblike radnih predmeta (najčešće tipske) i za tačno određene klase pribora (npr. sistem za projektovanje specijalnih pribora za operaciju obrade bušenjem na radnim predmetima u obliku diska);

- sistemi su, po pravilu, interaktivni i omogućavaju interaktivno biranje i projektovanje elemenata za pozicioniranje, eventualno za stezanje, a sve to po unapred definisanim kriterijumima;

- bazirani su na CAD programskim sistemima opšte (univerzalne) namene (AutoCAD i sl.).

Prednost ovih sistema je što je znanje iz posmatrane oblasti sistematizovano i kategorizovano na jednom mestu. Mana ovih sistema je upravo kruta algoritamska struktura (mala fleksibilnost) pogodna za rešavanje determinističkih zadataka. Znanje i metode znanja su izmešani, a novo znanje zahteva reprogramiranje.

Primenom ekspertnih sistema takođe je obezbeđeno čuvanje postojećih znanja na jednom mestu. Ekspertni sistemi koriste postojeća pravila za konstruisanje pribora i mogu relativno dobro da funkcionišu kao početni modeli. Međutim, oni su nefleksibilni, ne mogu da se prilagode i sami poboljšaju. Takođe, ne postoji formalizam koji omogućava detektovanje pojave mogućih konflikata u produkcionim pravilima kada se novo pravilo doda $u$ bazu. Stoga je ekspertske sisteme poželjno koristiti u proizvodnim sistemima sa dobro uhodanom proizvodnjom i stalnim programom proizvodnje. Analiza dobijenih rešenja je takođe prepuštena projektantu pribora i njegovom iskustvu. Ne postoji mogućnost revidiranja prethodnih faza ili unapređenja dobijenog rešenja, a da se celokupan postupak projektovanja pribora ne ponovi od početka. Ekspertni sistemi ne mogu u potpunosti zameniti eksperte iz područja projektovanja pribora, naročito u pogledu kreativnosti i korišćenja opšteg znanja.

Zaključivanje na osnovu slučajeva uspešno je primenjeno u fazi planiranja koncepcije pribora, tj. definisanja površina za pozicioniranje i stezanje, a za unapred poznate šeme. U daljoj fazi detaljnog projektovanja konstrukcije pribora, projektant je interaktivno u komunikaciji sa računarom birao potrebne elemente za projektovanje. Mana ovih sistema je što 
obezbeđuju dobijanje koncepcijskih rešenja. Put od koncepcije do finalne konstrukcije pribora je prepušten projektantu. Ovo može da traje veoma dugo, a da cilj kome se teži ne bude postignut. Dodatni problem u svim dosadašnjim istraživanjima bilo je jasno i sistematično definisanje svih potrebnih kriterijuma za sprovođenje modifikacija. Nijedan od prethodnih prilaza ne obezbeđuje izbor gotovih konstrukcija pribora, koje se mogu odmah primeniti, niti omogućava projektovanje novih konstrukcija pribora ako sistem ne pronađe dovoljno slično rešenje. Veliki problemi nastupaju ako u bazi podataka ne postoji dovoljno slično rešenje, tj. kada pribor treba projektovati od početka. Pitanje indeksiranja je takođe problematično. Ne postoji nijedan formalan postupak za definisanje indeksa i, u opštem slučaju, korišćenje indeksa je prepušteno iskustvu projektanta. Slabo razumevanje projektnih zahteva direktno je povezano sa neadekvatnim indeksiranjem. Ukoliko se projektni zahtevi za jedan pribor mogu adekvatno formalizovati, tada je veća verovatnoća da će ti zahtevi biti i iskorišćeni, ako ne direktno, a ono kao smernice za određivanje indeksnih atributa. Treba imati u vidu da su danas razvijene i neke tehnike za automatsko indeksiranje, kao što su kriterijumska metoda učenja, induktivna metoda učenja, metoda zasnovana na razlikama, metoda zasnovana na sličnostima itd. Analiza dobijenih rešenja je takođe prepuštena projektantu pribora i njegovom iskustvu. Ne postoji mogućnost revidiranja prethodnih faza ili unapređenja dobijenog rešenja, a da se celokupan postupak projektovanja pribora ne ponovi od početka. U nekim istraživanjima ovaj problem je rešavan odgovarajućom arbitražom konflikta dimenzija i funkcije elemenata pribora. Tako bi se u svakom momentu projektovanja mogli dobiti međurezultati, ali se problem time samo delimično rešava. Zaključivanje na osnovu slučajeva uspešno se može primeniti u fazi planiranja koncepcije pribora, tj. definisanja površina za pozicioniranje i stezanje, a za unapred poznate šeme. Osnovi problem u svim dosadašnjim istraživanjima bilo je jasno i sistematično definisanje svih potrebnih parametara za sprovođenje potrebnih modifikacija, bilo da je reč o fazi planiranja konstrukcije pribora, bilo da je reč o fazi projektovanja konstrukcije pribora. Skup trenutno raspoloživih pravila za projektovanje u ovom trenutku još nije dovršen. Takođe, nemoguće je definisati sva pravila za projektovanje jer njihov broj sa razvojem iskustva raste.

Svi dosadašnji prilazi u području primene neuronskih mreža u projektovanju pribora omogućavaju dobijanje parcijalnih koncepcijskih rešenja pribora. Put koji treba preći od koncepcije do realne kontrukcije pribora često je veoma dug, a veliko je pitanje da li je i rešiv. Prvi problem pri generisanju adekvatne neuronske mreže jeste kako skupiti dovoljnu količinu informacija za obučavanje na osnovu realnih primera iz prakse. Drugi problem jesu razvoj i 
sistematizacija svih kriterijuma za obučavanje neuronske mreže. Prednost neuronskih mreža leži u visokoj toleranciji prema poremećajima u ulaznim informacijama i u sposobnosti mreža da uče. Neuronske mreže su stoga veoma pogodne za rešavanje makar i parcijalnih problema u veoma kompleksnoj problematici projektovanja pribora čija je algoritamska interpretacija praktično nemoguća. Zato su neuronske mreže projektantu pribora dobra podrška u rešavanju problema.

Zajednička mana sistema za automatizovano projektovanje pribora jeste dobijanje koncepcijskih rešenja pribora na osnovu kojih bi projektant $u$ kasnijoj fazi birao odgovarajuće elemente i raspoređivao in na pogodno mesto. $\mathrm{Na}$ slikama 3.1 i 3.2. prikazani su primeri za koncepcijska i finalna rešenja konstrukcije pribora.
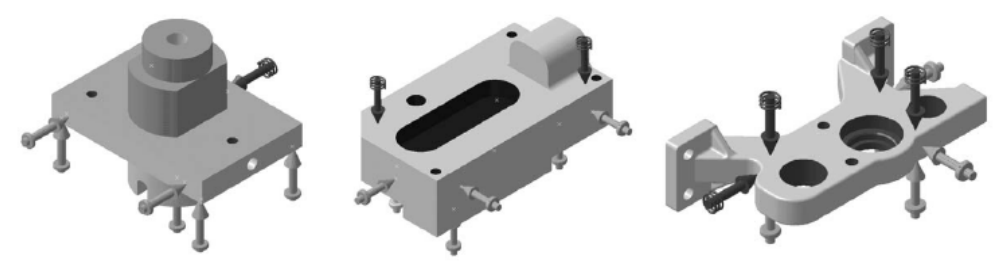

Slika 3.1. Koncepcijska rešenja konstrukcije pribora [66]
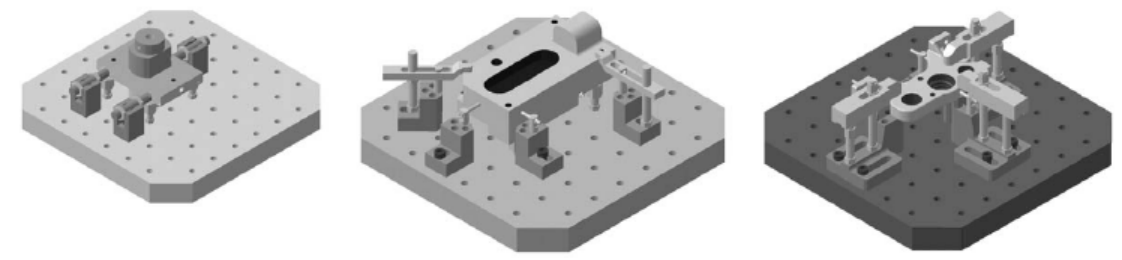

Slika 3.2. Finalna rešenja konstrukcije pribora [66]

U svim dosadašnjim istraživanjima, bez obzira na način rešavanja problema, sistemi su obezbeđivali dobijanje parcijalnih rešenja pribora, tj. izbor elemenata za pozicioniranje i/ili elemenata za stezanje. Ostale grupe elemenata (elementi tela pribora, elementi za vođenje alata, elementi za podešavanje položaja alata, itd.) nisu birane na osnovu prethodno definisanih kriterijuma, što se može okarakterisati kao velika mana sistema jer ovi elementi imaju veliku važnost u konstrukciji pribora.

Najrasprostraniji metod pozicioniranja radnog predmeta je po pravilu poznatom kao 3-2-1 (slika 3.3) [8, 142, 143, 182, 202, 231]. Ovaj metod prozicioniranja podrazumeva da se radnom predmetu oduzimaju:

- prvo tri stepena slobode preko primarne bazne površine korišćenjem tri elementa za pozicioniranje, 
- potom dva stepena slobode preko sekundarne bazne površine korišćenjem dva elementa za pozicioniranje,

- i na kraju, jedan stepen slobode preko tercijarne bazne površine korišćenjem jednog elementa za pozicioniranje.

Sva dosadašnja istraživanja baziraju se na metodi pozicioniranja 3-2-1, mada to nije jedini način pozicioniranja. Pri tome je zanemarena činjenica da se na ovaj način bitno povećava cena pribora, samim tim što se povećava broj sastavnih elemenata pribora. Takođe, povećava se i mogućnost pojave greške pri obradi.

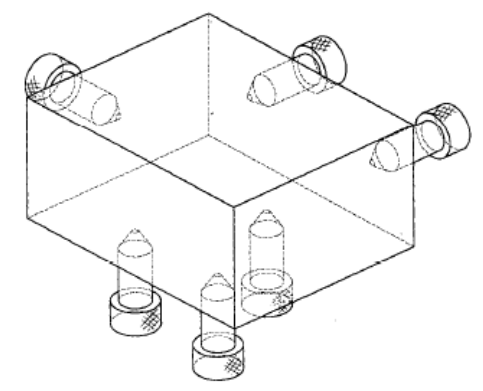

Slika 3.3. Metod pozicioniranja po pravilu 3-2-1 [172]

Definisanje površina za pozicioniranje i stezanje (slika 3.4) pri konvencionalnom načinu projektovanja pribora zavisi isključivo od znanja i iskustva projektanta. Projektantu je ostavljena mogućnost da samostalno rasuđuje o problemu i da na osnovu svog iskustva donosi odluke. Međutim, mnogi literaturni izvori koji tretiraju problematiku automatskog projektovanja pribora potenciraju značaj nivoa znanja i iskustva projektanta, ističući da „što je korisnik sistema iskusniji, dobijena rešenja će biti bolja“ $[4,7,8]$.
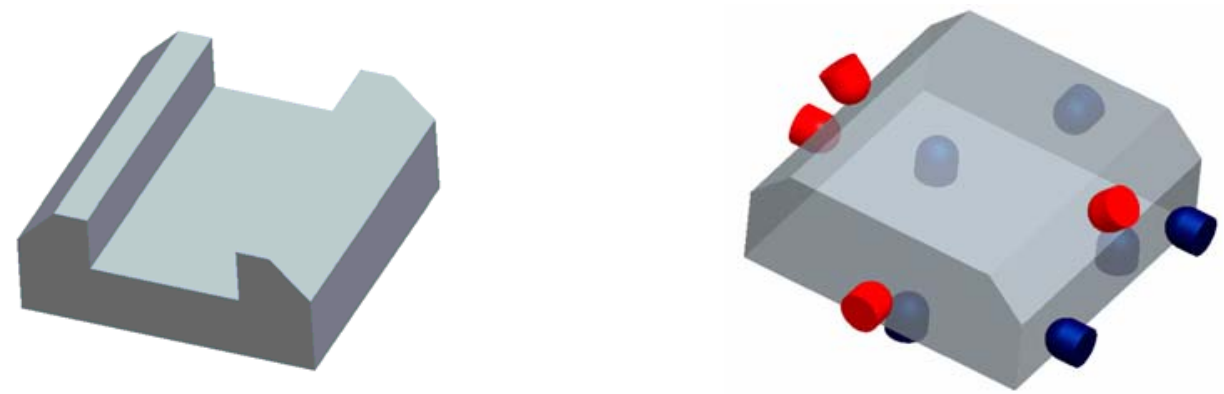

Slika 3.4. Primer definisanja površina za pozicioniranje i stezanje [36]

Uticaju greške pozicioniranja na ukupnu grešku izrade savremeni sistemi projektovanja ne poklanjaju odgovarajuću pažnju. Ne treba smetnuti sa 
uma da je u dosadašnjim istraživanjima verifikacija sistema bila izvršena na radnim predmetima jednostavnijeg oblika i geometrije (slika 3.5) čime se može dovesti u pitanje svrsishodnost razvoja ovih sistema, budući da se potrebne operacije obrade mogu izvršiti upotrebom univerzalnih pribora koji se isporučuju zajedno sa mašinom alatkom.
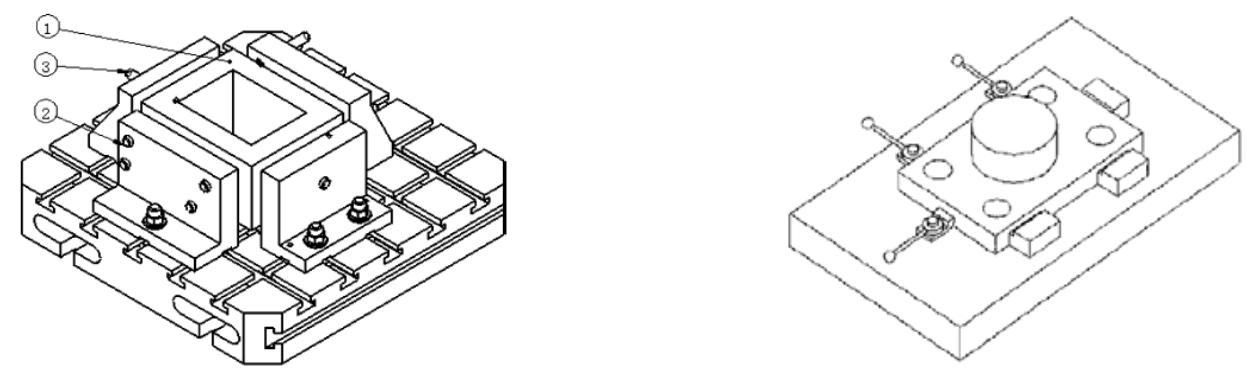

Slika 3.5. Izgled pribora i radnih predmeta projektovanih pomoću CAFD sistema [29, 101]

Kako su se sistemi za projektovanje pribora razvijali, tako se i pažnja mnogih istraživača sve više usmeravala na optimizaciju konstrukcije pribora. Optimizacija konstrukcije pribora započela je sa razvojem metodologija za izučavanje problema prihvatanja radnog predmeta. Za optimizaciju sistema radni predmet-pribor najčešće su se upotrebljavali numerički proračuni koji se izvode tzv. metodom konačnih elemenata, poznatom još i kao FEM ili FEA.

Prethodna istraživanja prate dva glavna nedostatka: koriste postupke za nelinearno programiranje koji, primenjeni na probleme konstrukcije pribora, ne daju rešenja globalnog ili približno globalnog optimuma i koriste funkcije cilja koje ne zavise eksplicitno od promenljivih konstrukcionih parametara, tj. od pozicija elemenata za pozicioniranje i elemenata za stezanje. Otud ovi postupci u najboljem slučaju daju poboljšano rešenje, ali ne i globalni optimum. Pored toga, rešenja dobijena primenom ovih metoda vrlo su osetljiva na kvalitet početnog (inicijalnog) rešenja koje se definiše na ulazu u proces optimizacije.

Metod konačnih elemenata je primenjivan na radni predmet (slika 3.6.), a ne na sklop radnog predmeta i pribora, što u svakom slučaju više odgovara praktičnoj strani. Na ovaj način nije moguće odrediti ponašanje čitavog sklopa, deformacije elemenata pribora i slično. Optimizacijom nisu obuhvaćeni kontaktno trenje u sistemu radni predmet-pribor, dinamička priroda sila rezanja i stabilnost radnog predmeta. 

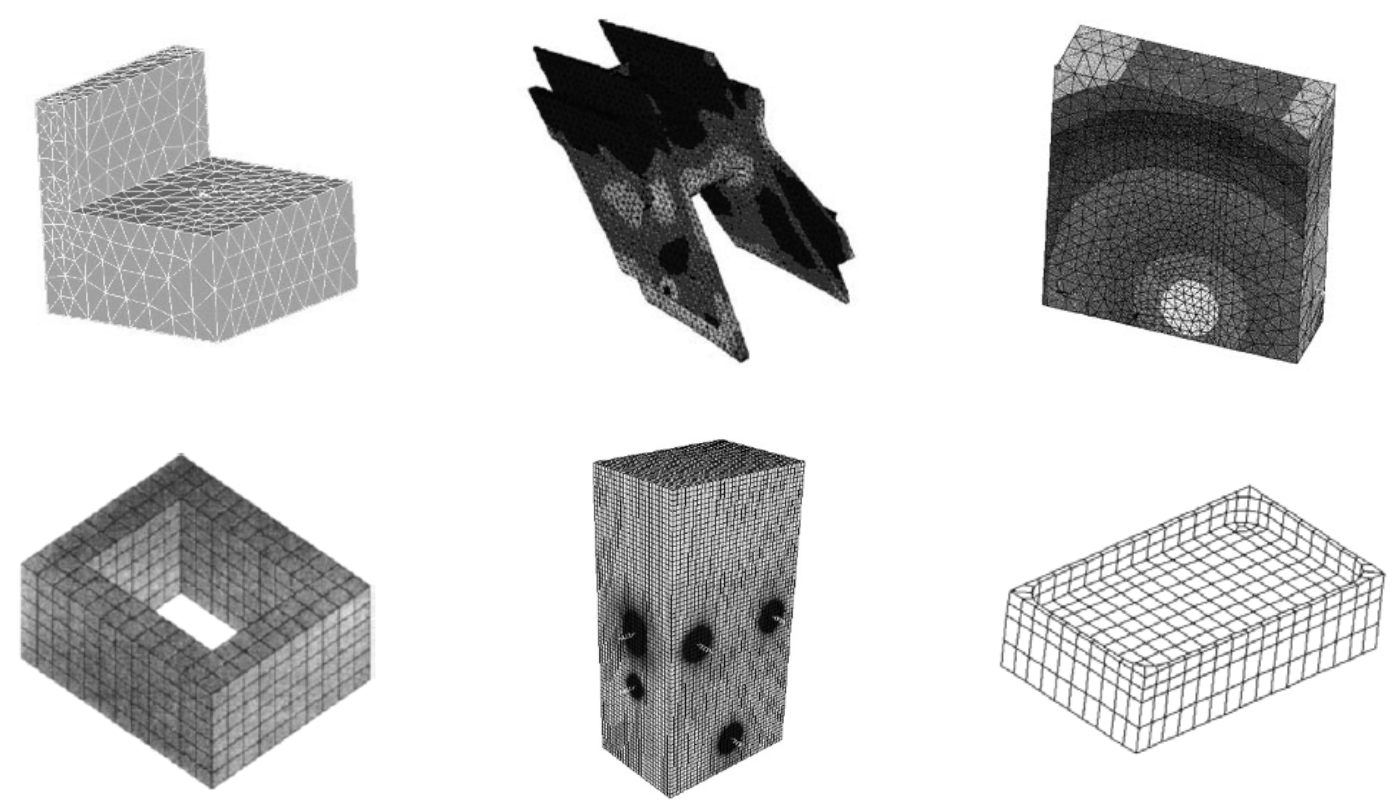

Slika 3.6. Primena metode konačnih elemenata na radnom predmetu [36, 55, 93, 145, 205]

Cilj optimizacije konstrukcije pribora jeste pronalaženje takve konfiguracije pribora koja će minimizirati elastičnu deformaciju radnog predmeta i kontaktne deformacije radnog predmeta na mestima kontakta radnog predmeta i elemenata pribora u toku celokupnog procesa obrade. Može se postaviti pitanje da li je to jedina funkcija cilja. Može se očekivati da će se vrlo brzo u proces optimizacije uključiti još neki veoma važni kriterijumi, kao što su cena pribora, njegova proizvodnost i slično.

Veliki nedostatak dosadašnjih istraživanja jeste što se uvek odnose na metod pozicioniranja 3-2-1 i što postupak optimizacije podrazumeva minimizaciju sila stezanja. Sile stezanja nisu jedine koje deluju na radni predmet $u$ toku obrade. Problem je prilično pojednostavljen, pošto se uvek vršila optimizacija za tri sile stezanja koje se dobijaju pomoću tri elementa za stezanje. U praksi se jako retko sreće slučaj korišćenja tri elementa za stezanje koji deluju u tri međusobno upravne ravni. Broj jednačina ravnoteže je uvek šest, tri translatorne i tri jednačine momenata. Broj nepoznatih varira od tri do šest, u zavisnosti od toga za koliko se elemenata za stezanje projektant odluči (slika 3.7 ). 


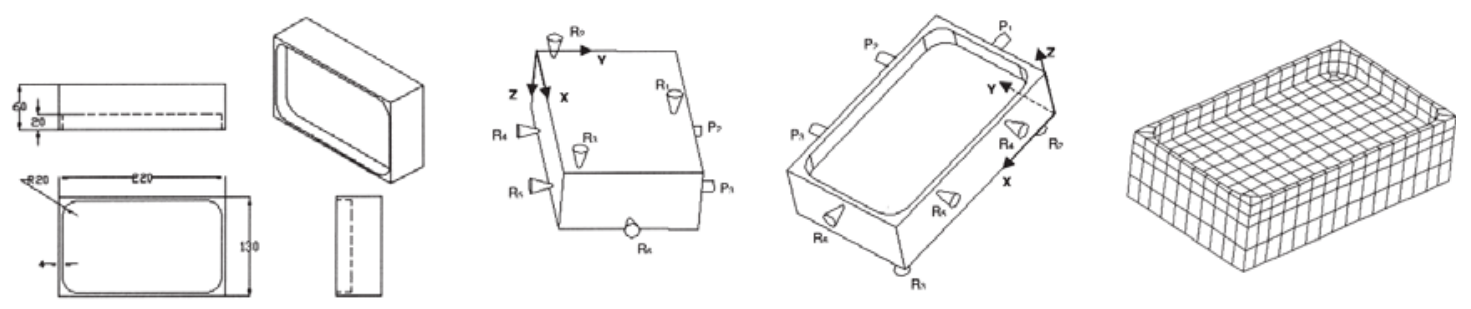

Slika 3.7. Primena metode pozicioniranja 3-2-1 u optimizaciji konstrukcije pribora uz pomoć MKE [205]

Pored elemenata za stezanje u kontaktu sa radnim predmetom su i elementi za pozicioniranje. Reakcije ovih elemenata (sile elemenata za pozicioniranje) takođe su veoma važne. Tokom obrade ove sile moraju biti pozitivnog smera. Ukoliko u bilo kom momentu obrade reakcija oslonaca postane manja od nule, to znači da se radni predmet pomerio (odvojio od elemenata za pozicioniranje), a to će sigurno proizvesti grešku u obradi.

Rešenja koja dobijamo pomoću MKE su približna ili aproksimativna rešenja. Zato treba postaviti pitanje njihove tačnosti, stabilnosti i konvergencije. Sa praktičnog stanovišta treba znati sa koje su strane približna rešenja u odnosu na tačno rešenje, odnosno da li su dobijeni rezultati na strani sigurnosti. Pod pojmom tačnosti ovde se podrazumeva bliskost približnog rešenja tačnom, odnosno odstupanje približnog od tačnog rešenja, dok se pod stabilnošću podrazumeva stabilnost u numeričkom, odnosno računskom procesu kod određivanja rešenja. Ako se razlika između uzastopnih rešenja sukcesivno smanjuje, postupak je konvergentan. O konvergenciji MKE zaključuje se na osnovu analize rezultata u zavisnosti od promene određenih parametara, kao što su veličina i broj konačnih elemenata, ili broj članova ili interpolacionih funkcija u približnom rešenju. Dokazom o konvergenciji daje se odgovor i na pitanje stabilnosti rešenja pošto je, po pravilu, za konvergentno rešenje numerički postupak stabilan. Greške u MKE po svojoj prirodi mogu biti dvojake: greške diskretizacije, koje predstavljaju razliku između realne geometrije tela i njegove aproksimacije sistemom konačnih elemenata; i greške interpolacionih funkcija, koje predstavljaju razliku između stvarnog polja nepoznatih funkcija i njihove aproksimacije pomoću polinoma. Greške diskretizacije se smanjuju sa povećanjem broja konačnih elemenata, odnosno sa smanjenjem njihove veličine, odnosno - greške proračuna teže nuli. 


\subsection{POSTAVKA HIPOTEZA I CILJA RADA}

$\mathrm{Na}$ osnovu pregleda literaturnih izvora, sprovedenih analiza i uočenih problema, postavljena je hipoteza da je moguće izgraditi sistem za automatizovano projektovanje pribora koji će obezbediti integralni prilaz u projektovanju i optimizaciji konstrukcije pribora. Sistem će uzimati u razmatranje grešku pozicioniranja, omogućiti definisanje optimalnih pozicija elemenata za pozicioniranje i stezanje za što širi spektar radnih predmeta i biti zasnovan na metodama veštačke inteligencije. Deo sistema za projektovanje treba da omogući izbor pojedinih elemenata pribora. Deo za optimizaciju treba da omogući, sa jedne strane, determinisanje optimalnih pozicija elemenata za pozicioniranje i stezanje kako bi se postigli potrebna tačnost i kvalitet obrađene površine radnog predmeta, uzimajući pri tome u obzir minimizaciju cene pribora i maksimizaciju njegove proizvodnosti, a sa druge strane, generisanje konstrukcije pribora bez kolizija. Integracija treba da bude takva da omogući da izlaz iz jedne faze bude prihvaćen i shvaćen od naredne faze. Sistem treba da omogući korekciju izlaznih vrednosti iz različitih faza projektovanja ukoliko se te vrednosti pokažu kao neadekvatne u toku testiranja. Ovaj aspekt integracije ograničen je na projektovanje i verifikaciju komponenti. Ukoliko komponenta ne prođe test, može biti vraćena u fazu projektovanja, gde rešenje biva ili korigovano ili proglašeno za neupotrebljivo. Ukoliko popravka nije moguća, tada alternativna rešenja treba tražiti unutar faze za projektovanje komponenti, a potom in verifikovati. Krajnji cilj jeste da se generišu kompletna rešenja pribora koja u potpunosti daju detalje fizičke strukture elemenata na osnovu definisanih zadataka koje svaki element pribora treba da obavi.

Pored ovih osnovnih hipoteza, mogu se izdvojiti još neke, sporedne. Tako bi sistem trebalo da:

- ima što je moguće veću univerzalnost, tj. mogućnost projektovanja pribora za što je moguće veći broj klasa geometrijskih oblika radnih predmeta i za što je moguće veći broj operacija obrade;

- obezbedi konzistentnost projektovanih rešenja pribora, kako se ne bi desilo da se u različitim vremenskim periodima za isti radni predmet $i$ istu operaciju obrade naprave različite konstrukcije pribora;

- bude zasnovan na što većem broju sistematizovanih i pouzdanih kriterijuma za projektovanje pribora;

- sadrži kriterijume izbora za što je moguće veći broj funkcionalnih grupa elemenata pribora, kako elemenata za pozicioniranje i stezanje, tako i 
elemenata tela pribora, elemenata za vođenje alata, podešavanje položaja alata, elemenata za vezu i nadogradnih elemenata;

- bude jednostavan i intuitivan za korišćenje;

- poseduje što je moguće veći stepen fleksibilnosti i proširljivost, tj. sistem koji će obezbeđivati lako modifikovanje kompletnog sistema i njegovo dopunjavanje novim informacijama;

- ima mogućnost lakog i brzog povezivanja sa drugim, sličnim sistemima tehnološke pripreme proizvodnje, prevashodno sa sistemima za projektovanje delova i tehnoloških procesa njihove izrade;

- obezbedi projektovanje potrebnog pribora u okviru vremenski prihvatljivog roka.

Ovakav sistem za automatizovano projektovanje pribora trebalo bi da omogući da se u okviru rada tehnološke pripreme proizvodnje, na efikasan način dođe do konačnog rešenja pribora, čime će se znatno uticati na podizanje tehnoekonomskih izlaznih pokazatelja ukupnog procesa proizvodnje. 


\section{4}

\section{STRUKTURA SISTEMA ZA PROJEKTOVANJE I OPTIMIZACIJU KONSTRUKCIJE PRIBORA}

\subsection{UVODNE NAPOMENE}

Pribori predstavljaju neophodni materijalni činilac svakog obradnog procesa, odnosno element obradnog sistema M-A-P-O (Mašina-Alat-PriborObradak).

Pri projektovanju pribora treba ispoštovati osnovne principe projektovanja od kojih se mogu izdvojiti sledeći: funkcionalnost, pouzdanost, tehnologičnost izrade, ekonomičnost i lakoća opsluživanja.

Osnovna namena pribora jeste realizacija zahtevane operacije obrade. Pri tome pribor treba da omogući zadovoljenje svih zahteva koji se tiču ostvarenja određenih tehnoloških mera i zahtevanog kvaliteta obrađenih površina, odnosno da omogući pouzdano pozicioniranje i stezanje radnog predmeta. Pri projektovanju pribora treba imati u vidu materijalne odnose između pribora, sa jedne strane, i radnog predmeta, mašine alatke, reznog alata, merila i radnika, sa druge strane, a takođe i procese koji se odvijaju u vremenu: postavljanje i skidanje radnog predmeta, određivanje njegovog položaja, oslanjanje, stezanje i otpuštanje, mašinsku obradu. Pored toga, treba zadovoljiti i zahteve koji se odnose na dovođenje sredstava za hlađenje i podmazivanje, odvođenje strugotine i zaštitu na radu. $U$ vezi sa radnim predmetom ističu se zahtevi koji se odnose na određene tehnološke mere, tolerancije i kvalitet obrađene površine, što je definisano konstruktivnim crtežom radnog predmeta, odnosno kartom operacije u tehnološkom postupku izrade dela. Konstruktivna i tehnološka dokumentacija, po pravilu, sadrže sve relevantne podatke potrebne za koncipiranje i razradu pribora (tehnološke mere, tolerancije, režime obrade na osnovu kojih se mogu odrediti sile rezanja, oblik pripremka, veličinu serije i slično). Navedene informacije služe kao 
polazna osnova koja definiše zadatak projektantu pribora. Uvažavajući navedene informacije, projektant koncipira idejno rešenje pribora, vrši određene proračune (proračun grešaka pozicioniranja, proračun potrebne sile stezanja, itd.) i pristupa razradi konstruktivne dokumentacije [178].

Pri projektovanju treba težiti zadovoljenju osnovnih funkcija pribora, tj.: funkcionalnosti pribora, visokoj pouzdanosti pribora, lakoći opsluživanja, omogućavanju bezbednog rada, niskoj ceni pribora.

Prilikom stvaranja koncepcije za konstrukciju pribora potrebno je obuhvatiti uticajne faktore koji su ranije navedeni i pridržavati se sledećih osnovnih pravila [58]:

- Neophodna je saradnja projektanta pribora sa tehnologom koji je postavio zahtev za izradu odgovarajućeg pribora $\mathrm{i}$ to je jedan od osnovnih preduslova za dobru konstrukciju.

- Kategorija pribora zavisi od tehnoloških mogućnosti mašine, broja radnih predmeta koji će se obrađivati tim priborom, kao i od vremena koje je potrebno da se pribor izradi. Kao osnovni kriterijum za izbor varijante za konstrukciju pribora mora se uzeti njegov tehnoekonomski efekat.

- Pre konstrukcije novog pribora potrebno je utvrditi da li postoji neki pribor koji se ne koristi, a koji bi se eventualno mogao adaptirati za novi proizvodni zadatak čime bi se postigla ušteda.

- Prilikom projektovanja pribora potrebno je koristiti što više standardnih elemenata.

- Pribori treba da poseduju zadovoljavajuću krutost koja se optimizacijom konstrukcije može postići pri maloj masi pribora, što doprinosi lakšoj manipulaciji priborima.

- Pri konstrukciji pribora treba nastojati: da sile rezanja i stezanja opterećuju čvrste delove pribora, pogotovo tamo gde se pojavljuju veća naprezanja, da mehanizmi za stezanje budu jednostavni, a tok sile najkraći. Vreme postavljanja i skidanja radnih predmeta treba da bude što je moguće kraće.

- Elementi pribora ne smeju da ometaju vidljivost i pristupačnost mestu obrade na radnom predmetu. Tečnost za hlađenje, ispiranje i podmazivanje treba slobodno da otiče sa mesta obrade.

- Elementi za stezanje, kao što su ručice i slično, treba da budu vezani za pribor. Ako se za stezanje koriste elementi koji su odvojeni od pribora, npr. ključevi, njihovom nepravilnom upotrebom može doći do povrede radnika i oštećenja pribora. 
- Pribor svojom konstrukcijom mora biti takav da ne omogućuje pogrešno postavljanje radnih predmeta, da obezbeđuje njihovo lako postavljanje i skidanje bez zamaranja radnika. Radnik ne sme da dođe u situaciju da razmišlja kako će postaviti radni predmet u pribor. Pribor mora lako da se postavlja na mašinu, a treba omogućiti i lako čišćenje strugotine sa njega i iz njega.

- Pribori moraju da budu sigurni u radu da ne bi došlo do povrede radnika. Između elemenata pribora mora da postoji dovoljno mesta za postavljanje i skidanje radnog predmeta kako ne bi došlo do ozlede ruke radnika. Sve oštre ivice trebalo bi zaobliti ili oboriti.

- U cilju projektovanja što ekonomičnijeg pribora potrebno je analizirati radne predmete koji se obrađuju na istim mašinama alatkama u određenom vremenskom periodu. Na osnovu te analize može se doći do zaključka da su pojedini radni predmeti veoma slični, te da se za njihovu obradu može konstruisati zajednički pribor. Za određene radne predmete, u ovakvom priboru, pojedini elementi mogu biti podesivi i/lii izmenjivi.

- Za elemente pribora potrebno je izabrati odgovarajući materijal. Elementi koji su u toku rada izloženi habanju moraju biti izrađeni od kvalitetnih čelika, a po potrebi, termički obrađeni i brušeni.

- Projektant pribora mora voditi računa i o tolerancijama dimenzija elemenata pribora. Pri tome uvek mora imati na umu da nije ekonomično, osim ako nije neophodno, propisivati suviše stroge tolerancije, jer se time poskupljuje izrada pribora.

- Prilikom projektovanja pribora potrebno je voditi računa i o estetskim zahtevima. To će obezbediti bolje čuvanje pribora od strane radnika koji ga koristi, ukazujući mu da je pribor skupo i visokovredno sredstvo za proizvodnju.

- Projektant pribora mora imati na umu da je izrada pribora prilično skupa i težiti da oni budu što je moguće jednostavniji, a da istovremeno u potpunosti zadovoljavaju funkciju za koju su namenjeni. Kod malih serija potrebno je jednostavnom konstrukcijom pribora osigurati obradu radnih predmeta odgovarajuće tačnosti. Kod velikih serija, radi veće ekonomičnosti primene pribora, njihova konstrukcija može biti složenija.

Svaki projektant na svoj način pristupa projektovanju pribora. Međutim, postoje neka prirodna i logična pravila (faze) kojih bi svaki projektant trebalo da se pridržava u toku projektovanja pribora. 
Faze projektovanja pribora su:

- analiza oblika i dimenzija radnog predmeta,

- analiza tehnološkog procesa, tj. operacije za koju se projektuje pribor,

- određivanje karakterističnih površina radnog predmeta (bazne, stezne itd.),

- proračun potrebnih parametara (tačnosti, krutosti, itd.),

- izbor elemenata pribora,

- izrada sklopnog crteža pribora,

- analiza dobijenog rešenja,

- korekcije konstrukcije pribora,

- arhiviranje crteža pribora.

Navedene faze projektovanja pribora predstavljaju logičnu celinu. Projektanti pribora, posebno projektanti sa manjim iskustvom, pri projektovanju pribora načelno bi trebalo da slede navedeni raspored aktivnosti.

\subsection{POSTAVLJANJE KONCEPCIJE I RAZVOJ SISTEMA ZA PROJEKTOVANJE I OPTIMIZACIJU KONSTRUKCIJE PRIBORA}

Na osnovu prethodno iznetih analiza i napomena, definisana je globalna koncepcija sistema za automatizovano projektovanje pribora i optimizaciju njegove konstrukcije (slika 4.1).

Sistem je namenjen za projektovanje novih konstrukcija pribora sa jedne strane, a sa druge strane je zasnovan na modularnom principu i interaktivnom radu. $U$ skladu sa tim, kao i trendovima u pogledu razvoja i načina korišćenja računara $u$ mašinskoj industriji, model ovog automatizovanog sistema koncipiran je na modularnom principu. Strukturu sistema čine četiri ključna modula (slika 4.1):

- modul za unos ulaznih informacija,

- modul za planiranje koncepcije pribora - optimizaciju položaja elemenata za pozicioniranje i stezanje,

- modul za sintezu pribora, 
- modul za izlazne informacije.

Koncepciju sistema čine i potrebne ulazne informacije, baza podataka, baza znanja, odgovarajuća programska podrška (softver), tehnička osnova (računarske komponente / hardver) i kadrovi za eksploataciju (projektanti).

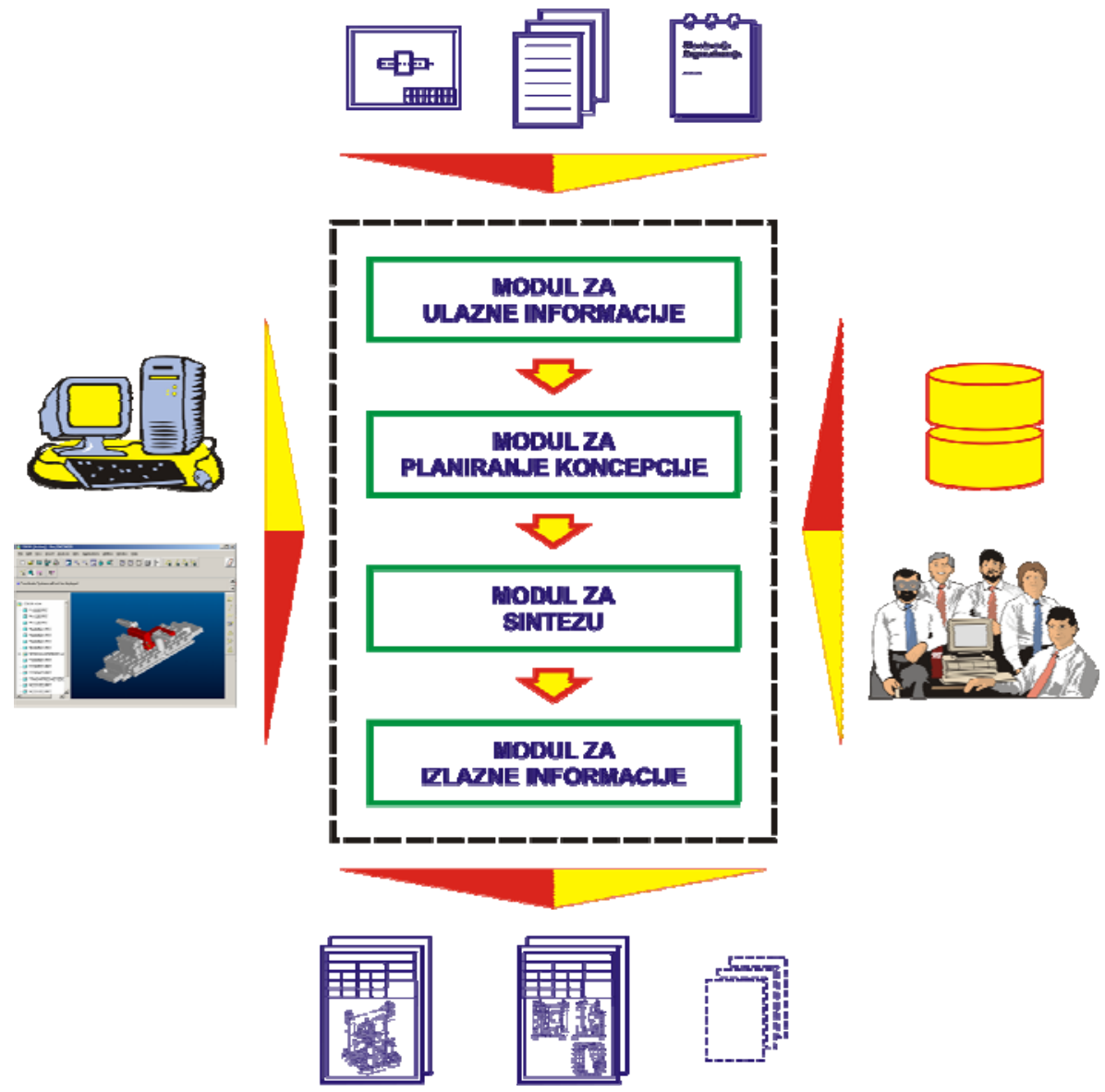

Slika 4.1. Struktura sistema za automatizovano projektovanje i optimizaciju konstrukcije pribora

Na bazi ulaznih informacija potrebnih za projektovanje pribora može se, u opštem slučaju, izvršiti njihovo kodiranje u „jezik“ razumljiv računaru. Kodirane informacije mogu se iskoristiti za determinisanje optimalnih pozicija elemenata za pozicioniranje i stezanje kako bi se dobili potrebna tačnost i kvalitet obrađene površine radnog predmeta, a uzimajući pri tome u obzir sa jedne strane, minimizaciju cene pribora, a sa druge strane, generisanje konstrukcije pribora bez kolizija. $U$ bazi podataka mogu biti zapamćena rešenja elemenata pribora i na odgovarajući način označena. Prilikom sinteze nove konstrukcije pribora moguće je pribor podeliti na određene funkcionalne 
celine i fazno (etapno) projektovati pribor. Na kraju je neophodno oblikovati pribor i generisati potrebnu tehničku dokumentaciju.

$\mathrm{Da}$ bi se prethodne aktivnosti uspešno obavile, potrebno je sistematizovati osnovne podloge za projektovanje i optimizaciju konstrukcije pribora, izgraditi bazu podataka, razviti sisteme programa za automatizovani izbor elemenata pribora, odabrati odgovarajuću programsku podršku i tehničku osnovu.

\subsubsection{Koncepcije pojedinih modula sistema}

\subsubsection{Modul za unos ulaznih informacija}

Modul za ulazne informacije omogućava unos svih potrebnih informacija, neophodnih za projektovanje pribora, koje se mogu podeliti na dve veće grupe: informacije o radnom predmetu i tehnološke informacije. Ulazne informacije sadrže podatke za obradu u okviru svih narednih modula posmatranog sistema.

Ulazne informacije obuhvataju informacije o:

- vrsti obrade (struganje, bušenje, glodanje, brušenje, provlačenje, rendisanje, izrada ozubljenja, itd.),

- grupi mašina alatki (strugovi, bušilice, glodalice, brusilice, provlakačice, rendisaljke, testere, itd.),

- podgrupi mašina alatki (univerzalni strug, kopirni strug, revolver strug, vertikalna jednovretena bušilica, horizontalna jednovretena bušilica, bušilice sa viševretenom glavom, viševretene bušilice, agregatne bušilice, horizontalna glodalica, vertikalna glodalica, univerzalna glodalica, kopirna glodalica, ravne brusilice, univerzalna brusilica, kopirna brusilica, brusilice za okruglo brušenje, itd.)

- tipu mašine alatke (konvencionalna, numerički upravljana),

- konkretnoj mašini alatki na kojoj se izvodi obrada (stanju površine radnog stola, dimenzijama žlebova radnog stola, itd.)

- broju istovremeno obrađivanih radnih predmeta (jedan, dva, tri, itd.),

- broju alata (jedan alat, više identičnih alata, više različitih alata, itd.), 
- broju površina za obradu (jedna površina, više identičnih površina raspoređenih po pravcu, više identičnih površina raspoređenih po krugu, itd.),

- načinu ostvarivanja veze pribora sa mašinom alatkom (glavno vreteno, radni sto),

- fiksiranju pribora u toku obrade (elementima pribora, manuelno),

- veličini serije,

- obliku radnog predmeta (prizmatični, rotacioni, nepravilnog oblika),

- gabaritnim dimenzijama radnog predmeta (dužina, visina, širina, itd.),

- broju oduzetih stepeni slobode radnom predmetu (tri, četiri, pet, šest)

- metodu pozicioniranja radnog predmeta (3-2-1, 4-1-1),

- osnovnoj karakteristici pribora (prihvatanje i stezanje po spoljašnjoj površini, prihvatanje i stezanje po unutrašnjoj površini, prihvatanje i stezanje i po spoljašnjoj i po unutrašnjoj površini, itd.),

- silama i momentima koji se javljaju u toku procesa obrade (sile i momenti rezanja, itd.),

- tipu baznih površina (spoljašnja ravna, unutrašnja ravna, spoljašnja cilindrična, unutrašnja cilindrična, spoljašnja konična, unutrašnja konična, spoljašnja sferna, unutrašnja sferna, itd.),

- integralnosti baznih površina (integralna, stepenasta),

- kvalitetu baznih povšina (IT),

- obliku baznih površina (pravougaona, kružna, trougaona, itd.),

- karakterističnim dimenzijama baznih površina,

- položaju baznih površina u odnosu na radni sto mašine alatke (horizontalan, vertikalan, pod uglom),

- broju pravaca dejstva sile stezanja (jedan, dva, tri),

- tipu steznih površina po pojedinim pravcima (spoljašnja ravna, unutrašnja ravna, spoljašnja cilindrična, unutrašnja cilindrična, spoljašnja konična, unutrašnja konična, spoljašnja sferna, unutrašnja sferna),

- šemi stezanja po pojedinim pravcima (sila stezanja i sila rezanja su istog pravca i smera; sila stezanja i sila rezanja su istog pravca a suprotnog smera; sila stezanja je upravna na silu rezanja; sila stezanja je pod uglom u odnosu na silu rezanja; sila stezanja je paralelna sa ravni 
momenta rezanja; sila stezanja je upravna na ravan momenta rezanja; sila stezanja je pod uglom u odnosu na ravan momenta rezanja, itd.),

- pogonu stezanja po pojedinim pravcima (ručni, pneumatski, hidraulični, električni, kombinovani),

- pravcu dejstva sile stezanja u odnosu na baznu površinu po pojedinim pravcima (paralelan, upravan, itd.),

- intenzitetu sile stezanja po pojedinim pravcima,

- obliku steznih površina,

- karakterističnim dimenzijama steznih površina.

Neke od ulaznih informacija su karakteristika samo određene operacije obrade. Tako npr., za operaciju bušenja na konvencionalnim mašinama alatkama potrebna ulazna informacija je i prečnik bušenja ili za operaciju glodanja na konvencionalnim mašinama alatkama - broj tehnoloških mera koji definiše površinu za obradu.

Struktura modula za unos ulaznih informacija je prikazana na slici 4.2.

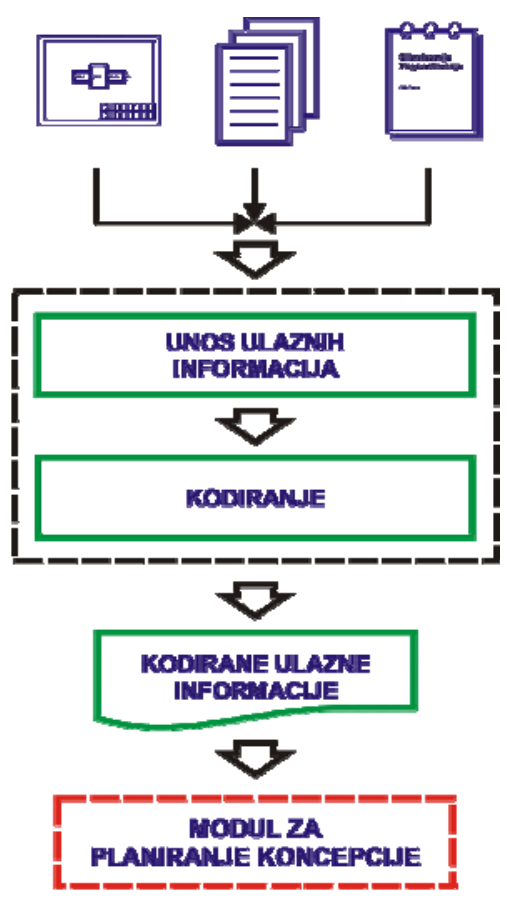

Slika 4.2. Struktura modula za unos ulaznih informacija

Unos ulaznih informacija podrazumeva unos informacija o karakteristikama obrade, radnog predmeta, pozicioniranja i stezanja, a sve 
prema prethodno prikazanoj sistematizaciji. Ulazne informacije se unose $u$ sistem i na odgovarajući način kodiraju. Na izlazu iz ovog modula se dobijaju kodirane informacije, neophodne za projektovanje nove konstrukcije pribora, koje će se kasnije koristiti za rad i obradu u svim narednim modulima sistema.

\subsubsection{Modul za planiranje koncepcije pribora}

Osnovna funkcija modula za planiranje koncepcije pribora je da determiniše površine i tačke preko kojih će se izvesti pozicioniranje i stezanje radnog predmeta. Na ovaj način se definiše skeletna konstrukcija pribora budući da su elementi za pozicioniranje i stezanje najvažniji sastavni elementi svakog pribora i jedini elementi pribora koji dolaze neposredno u kontakt sa radnim predmetom. Ovi elementi direktno utiču na tačnost obrade, na proizvodnost i cenu, na izbor ostalih elemenata, itd.

Determinisanje tačaka za pozicioniranje i stezanje može se izvršiti u tri koraka koje čine:

- determinisanje površina za pozicioniranje,

- determinisanje površina za stezanje i

- determinisanje tačaka za pozicioniranje i stezanje.

Determinisanje površina za pozicioniranje može se izvršiti na osnovu karakterističnih šema pozicioniranja. Karakteristične šeme pozicioniranja se kodiraju na osnovu podataka prikazanih u tabeli 4.1.

Pozicioniranje nije ništa drugo nego oduzimanje određenog broja stepeni slobode radnom predmetu pomoću odgovarajućih oslonaca (elemenata za pozicioniranje). Kako bi se moglo izvršiti pravilno determinisanje površina za pozicioniranje, potrebno je jednoznačno odrediti te površine $u$ prostoru, a uzimajući u obzir pravilnu orijentaciju radnog predmeta. 


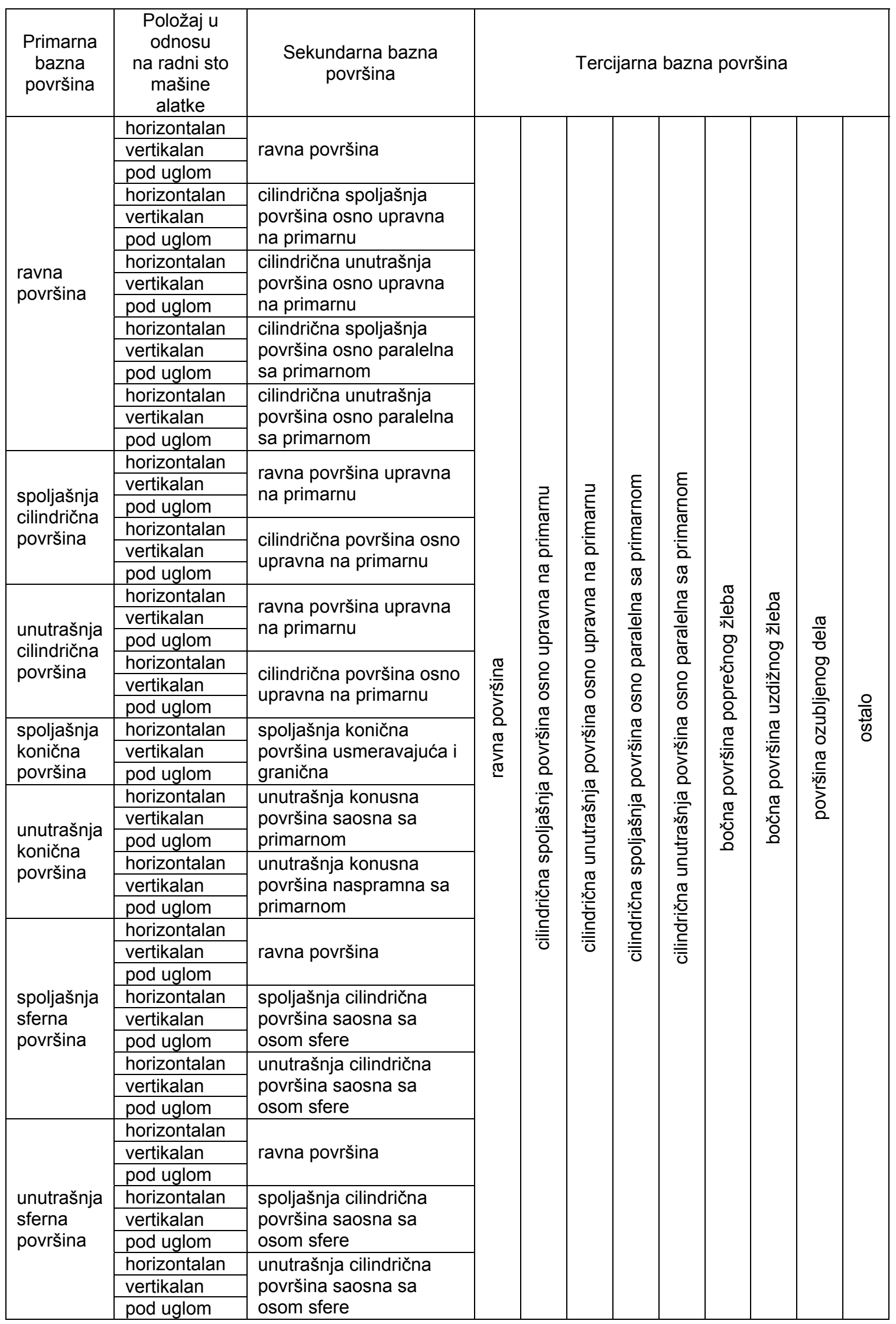

Tabela 4.1. Karakteristične šeme pozicioniranja 
Položaj bilo kog elementa u prostoru može biti jednoznačno određen pomoću odgovarajućih koordinata u odnosu na neki usvojeni koordinatni sistem, koji može, a ne mora biti vezan za neku karakterističnu tačku na radnom predmetu. U oba prethodna slučaja je moguće odgovarajućim sistemom označavanja potpuno definisati pojedine površine od značaja (bazne i stezne). Svaka površina može da ima sopstveni koordinatni sistem. Za predstavljanje elementarnih površina radnog predmeta pogodno je koristiti Dekartov koordinatni sistem. Glavni koordinatni sistem (XYZ), u odnosu na koji se definiše položaj površina, vezan je za radni predmet. Njegov položaj u prostoru u odnosu na radni predmet je proizvoljan, ali je poželjno da se nalazi u preseku baznih površina (ukoliko je moguće), tako da koordinatne ravni pripadaju baznim površinama. Tačke početaka koordinatnih sistema se nazivaju čvornim tačkama (tačka A). Početak koordinatnog sistema elementarnih površina, tj. čvornu tačku, treba postaviti tako da pripada površini. U odnosu na čvornu tačku potrebno je jednoznačno definisati geometriju elementarne površine radnog predmeta (L1, L2).

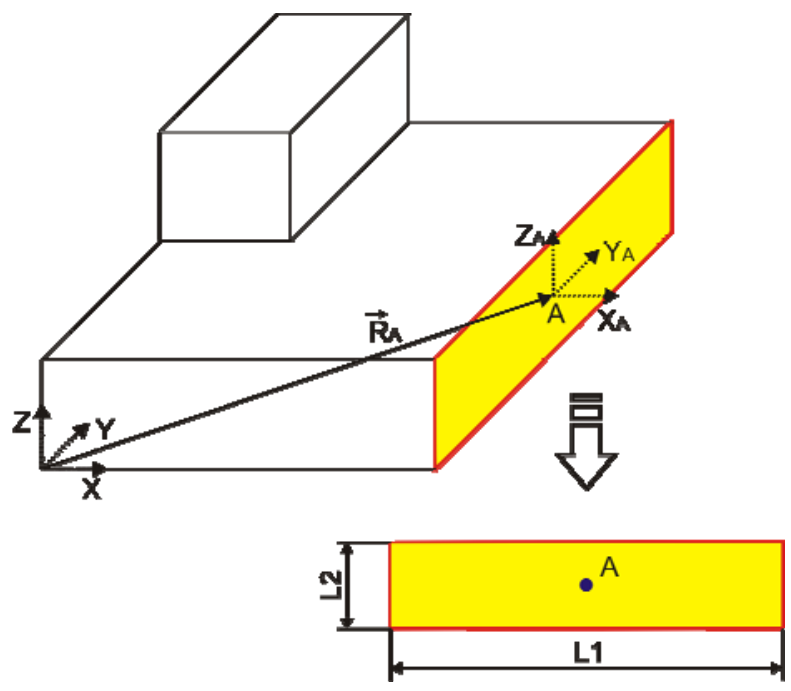

Slika 4.2. Definisanje položaja površina u prostoru

Sa druge strane, površine za pozicioniranje je uvek potrebno tako izabrati da se njihovim izborom ne utiče na ukupnu grešku koja nastaje $u$ procesu izrade radnog predmeta.

U procesu izrade radnog predmeta dolazi do odstupanja od zahtevanog geometrijskog oblika i nazivnih mera datih crtežom radnog predmeta. Greške obrade su stalna pojava u svakom procesu obrade gde se menja geometrijski oblik, dimenzija ili struktura materijala. Osnovni kriterijum tačnosti izrade je da 
nastala greška izrade $(\Delta)$ mora biti manja od dozvoljene tolerancije izrade $(T)$, $\mathrm{tj}$. :

$$
\Delta \leq \mathrm{T}
$$

Dve osnovne grupe grešaka su greške pre obrade i greške u toku obrade. Ove greške nastaju kao posledica različitih uticajnih faktora i one se ne mogu uvek precizno računski odrediti, izuzev grešaka pozicioniranja $\left(\Delta_{p}\right)$. Zbog toga se sve greške osim grešaka pozicioniranja ne posmatraju pojedinačno, već zbirno, kao zbirna greška $\left(\Delta_{z}\right)$, pa se može napisati:

$$
\Delta_{\mathrm{p}}+\Delta_{\mathrm{z}} \leq \mathrm{T}
$$

Uzima se da je zbirna greška približno jednaka, odnosno nešto manja od srednje ekonomske tačnosti odgovarajuće obrade. Ekonomska tačnost obrade može se izraziti kvalitetom tolerancije obrade IT koja se može postići pri određenoj obradi, a pri normalnim uslovima rada. Tabela 4.1 daje kvalitet tolerancija IT za ekonomsku tačnost pojedinih vrsta obrade. Prva varijanta je po ruskoj literaturi, a druga je preuzeta iz domaće prakse za obradu radnih predmeta srednjih dimenzija.

\begin{tabular}{|l|l|c|c|}
\hline \multicolumn{2}{|c|}{ Vrsta obrade } & Kvalitet tolerancija IT za ekonomsku tačnost obrade \\
\cline { 2 - 4 } & I varijanta & II varijanta \\
\hline \multirow{3}{*}{ Struganje } & grubo & $12 \div 16$ & $12 \div 14$ \\
\cline { 2 - 4 } & poluzavršno & $6 \div 12$ & $7 \div 12$ \\
\cline { 2 - 4 } & završno & 6 & $6 \div 7$ \\
\hline Bušenje & $11 \div 16$ & $12 \div 14$ \\
\hline Proširivanje, upuštanje & $8 \div 16$ & $10 \div 12$ \\
\hline Razvrtanje & $6 \div 7$ & $6 \div 8$ \\
\hline \multirow{3}{*}{ Glodanje } & grubo & $12 \div 16$ & $12 \div 14$ \\
\cline { 2 - 4 } & poluzavršno & $11 \div 16$ & $10 \div 12$ \\
\cline { 2 - 4 } & završno & $8 \div 9$ & $8 \div 9$ \\
\hline \multicolumn{2}{|l|}{ Provlačenje } & $6 \div 9$ & $6 \div 9$ \\
\hline \multirow{2}{*}{ Brušenje } & grubo & $6 \div 9$ & $8 \div 10$ \\
\cline { 2 - 4 } & završno & \multirow{2}{*}{$6 \div 9$} \\
\hline
\end{tabular}

Tabela 4.1. Kvalitet tolerancija za ekonomsku tačnost pojedinih vrsta obrade

Greške pozicioniranja nastaju ili usled usvajanja pomoćnog sedišta ili pak usled zazora između površina za pozicioniranje na radnom predmetu i odgovarajućih elemenata pribora.

Iz obrasca (4.2) sledi da je greška pozicioniranja koja se može dozvoliti (dozvoljena greška pozicioniranja) jednaka:

$\Delta_{\mathrm{pd}} \leq \mathrm{T}-\Delta_{\mathrm{z}}$ 
Stvarna greška pozicioniranja $\Delta \mathrm{p}_{\mathrm{s}}$ mora biti manja od dozvoljene:

$$
\Delta_{\mathrm{ps}}<\Delta_{\mathrm{pd}}
$$

Obrasci za proračun grešaka pozicioniranja za karakteristične šeme pozicioniranja su detaljno izloženi u $[123,135,146]$.

Radni predmet se može pozicionirati tako da mu greška pozicioniranja bude ili jednaka nuli $\left(\Delta_{p}=0\right)$ ili različita od nule $\left(\Delta_{p} \neq 0\right)$. Sa stanovišta tačnosti obrade, bolje je da je greška pozicioniranja jednaka nuli. Međutim, moguće je da u određenim uslovima greška pozicioniranja bude različita od nule i da njen zbir sa zbirnom greškom obrade $\left(\Delta_{z}\right)$ bude manji od tolerancije izrade $(T)$, tj. $\Delta_{\mathrm{p}}+\Delta_{\mathrm{Z}}<\mathrm{T}$, ali da cena konstrukcije pribora bude niža ili njegova proizvodnost znatno veća, te se ovo rešenje može smatrati i boljim u odnosu na prethodno $\left(\Delta_{\mathrm{p}}=0\right)$.

Takođe, u nekim slučajevima radni predmet nije moguće pozicionirati tako da se izbegne greška pozicioniranja (slika 4.4). Može se postaviti pitanje koji je od ovih slučajeva najbolji.
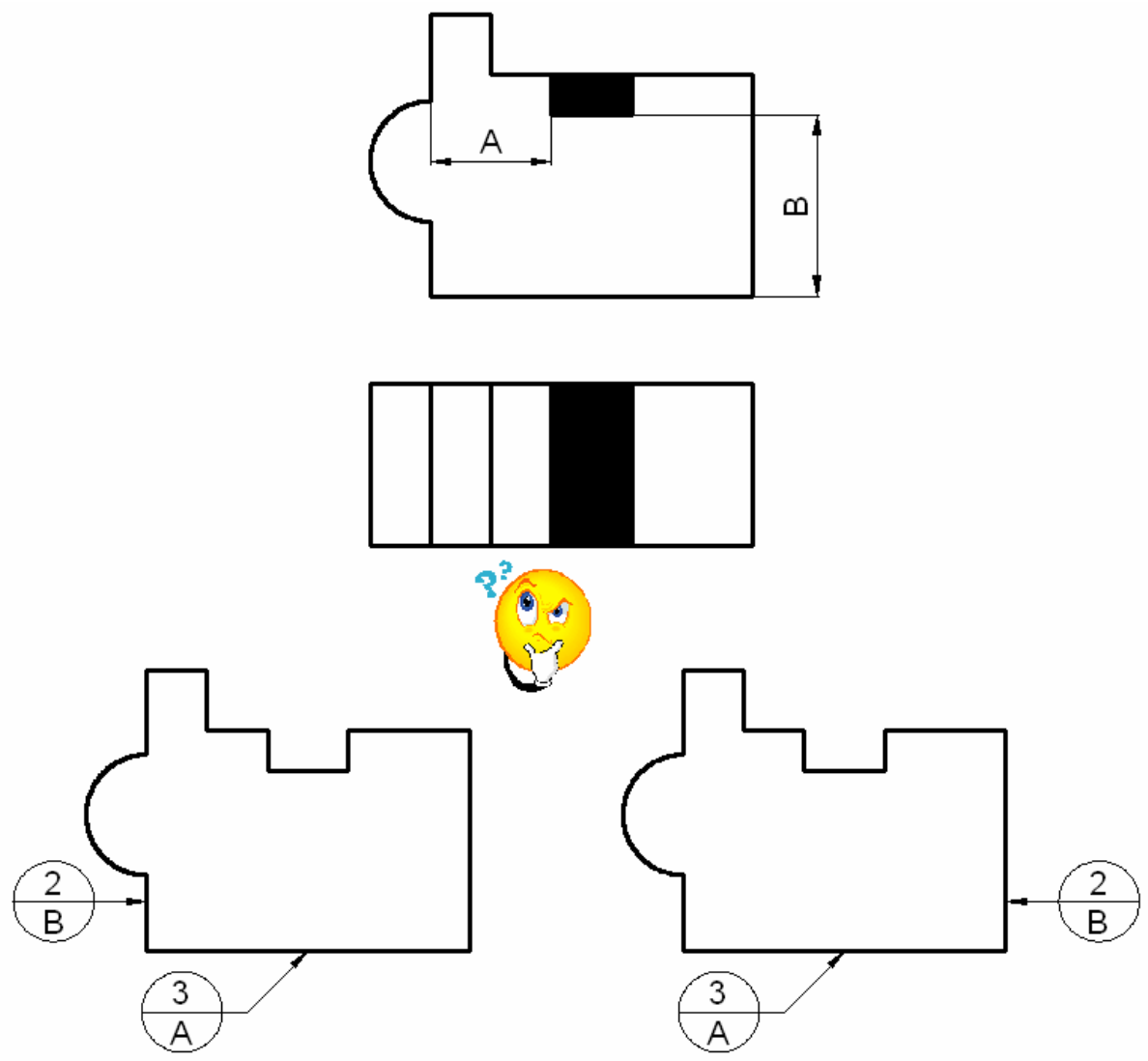

Slika 4.3. Primer dve koncepcije pozicioniranja istog radnog predmeta

$$
(\Delta p=0, \Delta p \neq 0)
$$




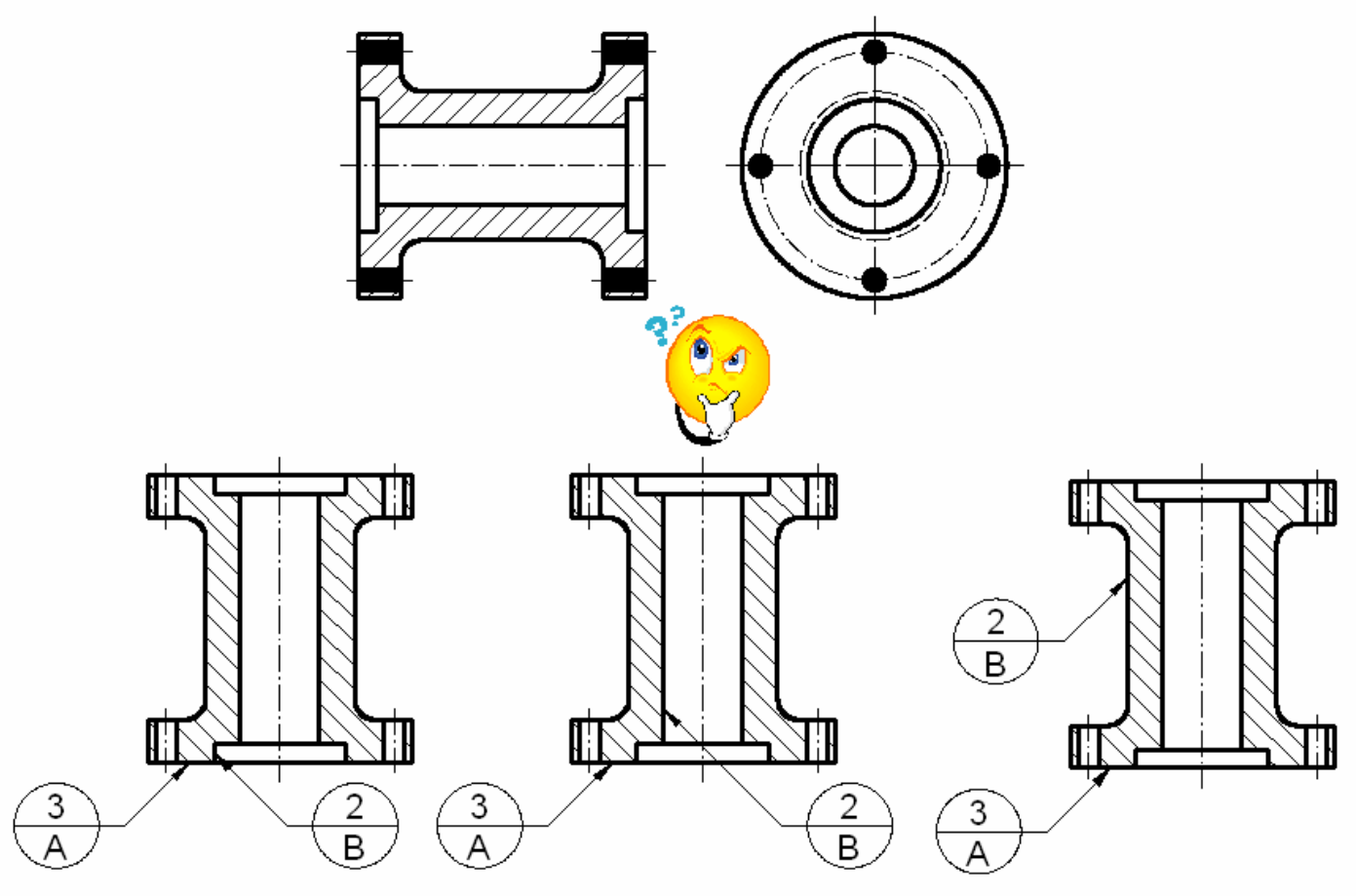

Slika 4.4. Primer tri koncepcije pozicioniranja istog radnog predmeta $(\Delta p \neq 0)$.

Struktura segmenta za determinisanje površina za pozicioniranje je prikazana na slici 4.5. Na osnovu ulaznih informacija, tj. orijentacije radnog predmeta $u$ toku procesa obrade $u$ određenoj operaciji obrade na konkretnoj mašini alatki, površina radnog predmeta, datih tehnoloških mera i njihovih geometrijskih specifikacija, vrši se generisanje mogućih površina za pozicioniranje i pritom uzima u obzir potreban broj stepeni slobode koji treba oduzeti radnom predmetu. Nakon definisanja mogućih rešenja šema pozicioniranja, proverava se veličina greške pozicioniranja, te se sva rešenja (ukoliko uopšte postoje) koja zadovoljavaju uslov da je greška pozicioniranja jednaka nuli ili je dovoljno mala selektuju, odnosno izdvajaju. U sledećim modulima će se doneti odluka o konkretnoj šemi. Na izlazu iz ovog segmenta se dobija jedno ili više mogućih rešenja šema pozicioniranja.

Za izabrane šeme pozicioniranja definišu se potom moguće šeme stezanja (površine za stezanje). Površine za stezanje je najbolje odabrati tako da se nalaze na površinama naspram površina za pozicioniranje (slika 4.6).

Nakon što se definišu moguće šeme pozicioniranja i stezanja, definišu se tačke (položaji) za pozicioniranje i stezanje, tj. mesto kontakta ovih elemenata sa radnim predmetom. 


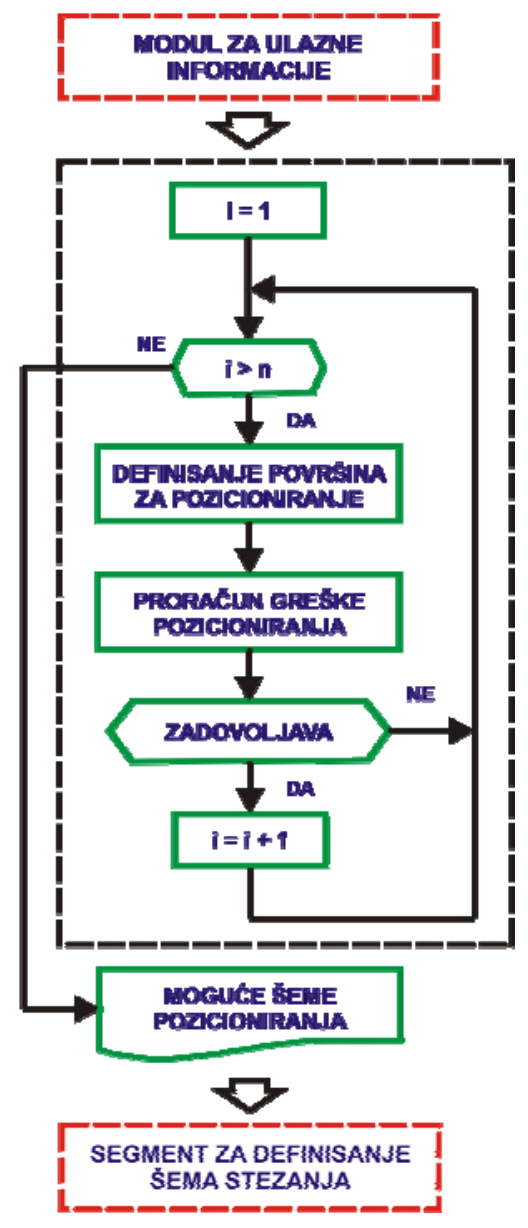

Slika 4.5. Struktura segmenta za determinisanje mogućih šema pozicioniranja

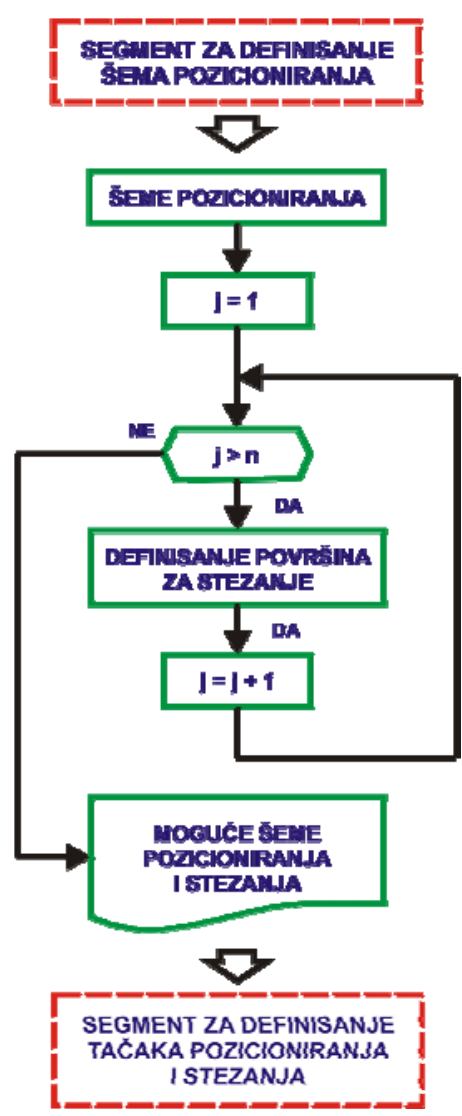

Slika 4.6. Struktura segmenta za determinisanje mogućih šema stezanja

Definisanje položaja elemenata za pozicioniranje/stezanje sastoji se od dva koraka:

- definisanja inicijalne pozicije elemenata za pozicioniranje/stezanje,

- generisanja optimalne pozicije elemenata za pozicioniranje/stezanje.

Inicijalna pozicija elemenata za pozicioniranje se definiše kao centar određene dvodimenzionalne površine preko koje se vrši pozicioniranje $u$ slučaju da sa tom površinom dolazi u kontak jedan element za pozicioniranje. U slučaju postavljanja $n$ elemenata za pozicioniranje, bazna površina se deli na $n$ jednakih delova, a inicijalna pozicija svakog elementa je centar svake od $n$ površina. Da bi se generisala optimalna pozicija elemenata za pozicioniranje, 
vrši se diskretizacija bazne površine na konačan broj malih površina, tj. na mrežu za pozicioniranje koja definiše moguće položaje elemenata za pozicioniranje. Tačan položaj elemenata za pozicioniranje je moguće ostvariti tek u narednoj fazi projektovanja, nakon što se u razmatranje uzmu i sve sile koje deluju na radni predmet u toku obrade.
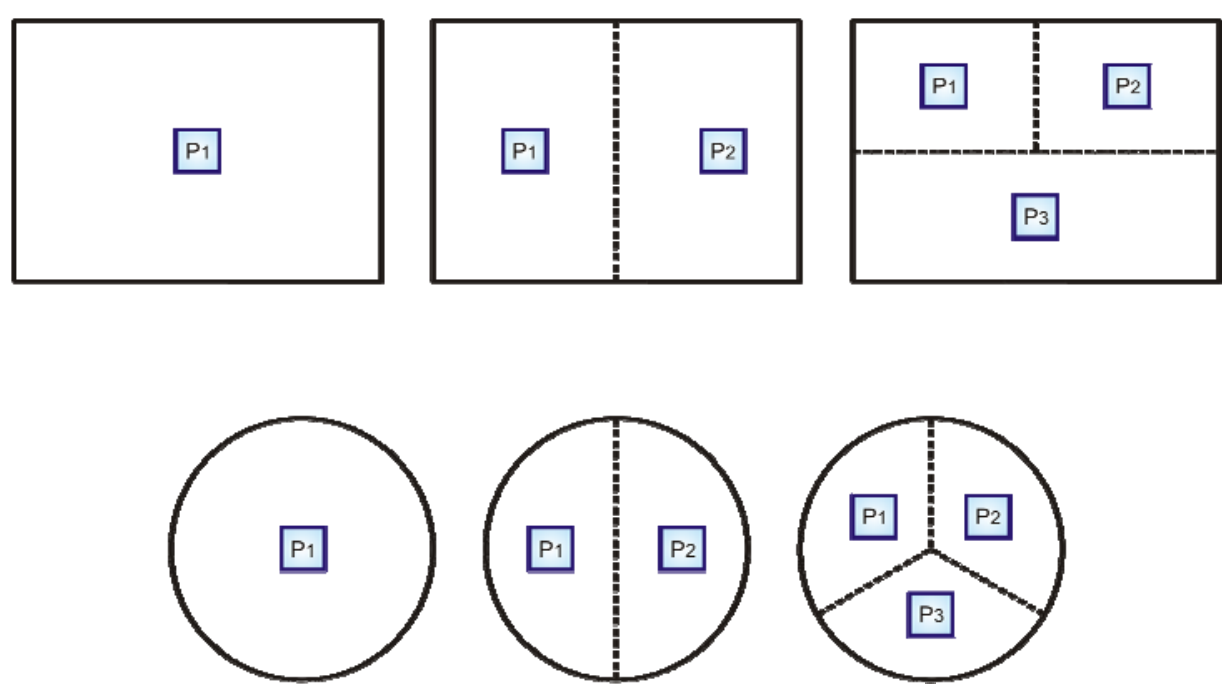

Slika 4.7. Definisanje inicijalne površine za pozicioniranje na primeru površina u obliku pravougaonika i kruga

Dosadašnja istraživanja u polju optimizacije položaja elemenata za pozicioniranje podrazumevala su strategiju koja se sastojala iz dva osnovna koraka (slika 4.8):

- postaviti elemente za pozicioniranje na što je moguće većem rastojanju jedan u odnosu na drugi;

- sukcesivno menjati položaj elemenata za poziciranje po ivicama radnog predmeta ili po pravoj prema poziciji pretpostavljenog mesta stezanja.

Veliki nedostatak ovih prilaza jeste što je oblast mogućih rešenja prilično sužena i što je broj iteracija po pravilu velik kako bi se došlo do prihvatljivog rešenja. U novorazvijenom prilazu osnovna pretpostavka jeste da se element hipotetički može nalaziti bilo gde na odgovarajućoj površini $i$ da oblast pretrage, a samim tim i pomeranja elemenata, može biti u bilo kom pravcu na postojećoj površini radnog predmeta (slika 4.9). 

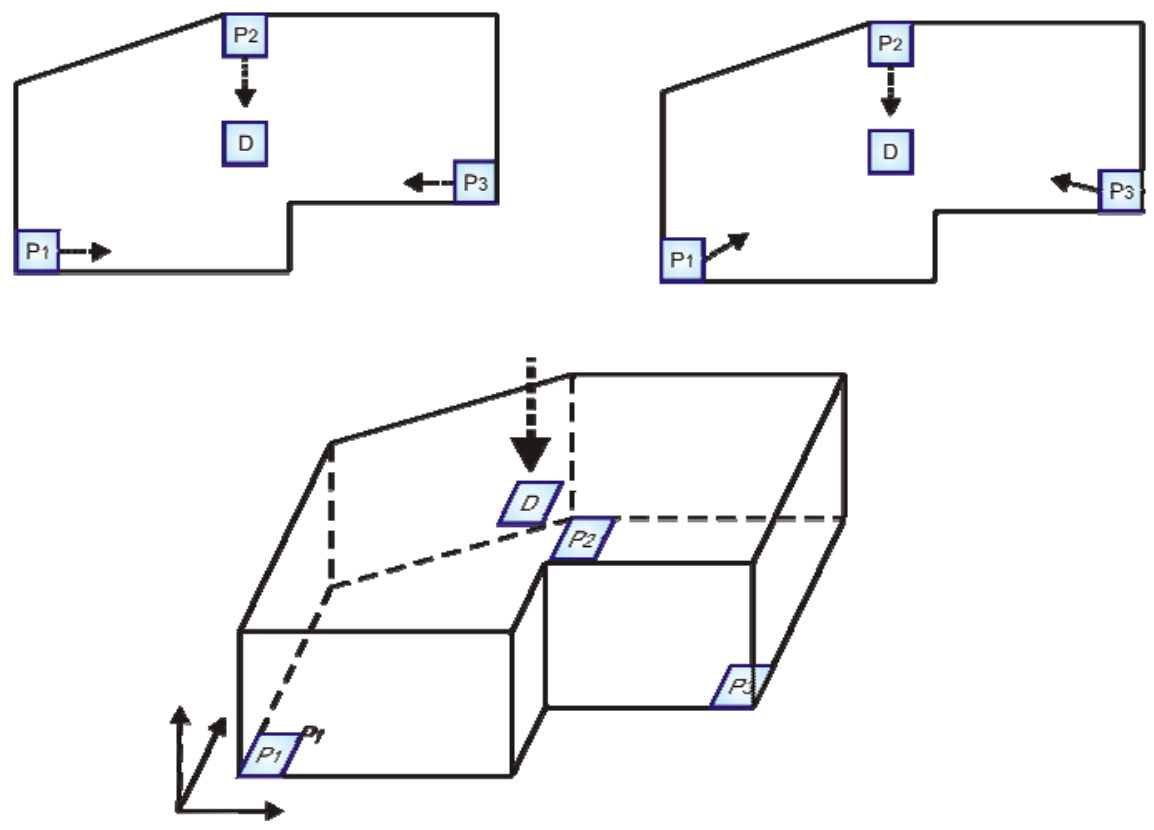

Slika 4.8. Strategije mogućih pomeranja elemenata za baziranje u pravcu dejstva elementa za stezanje i u pravcu elementa za pozicioniranje
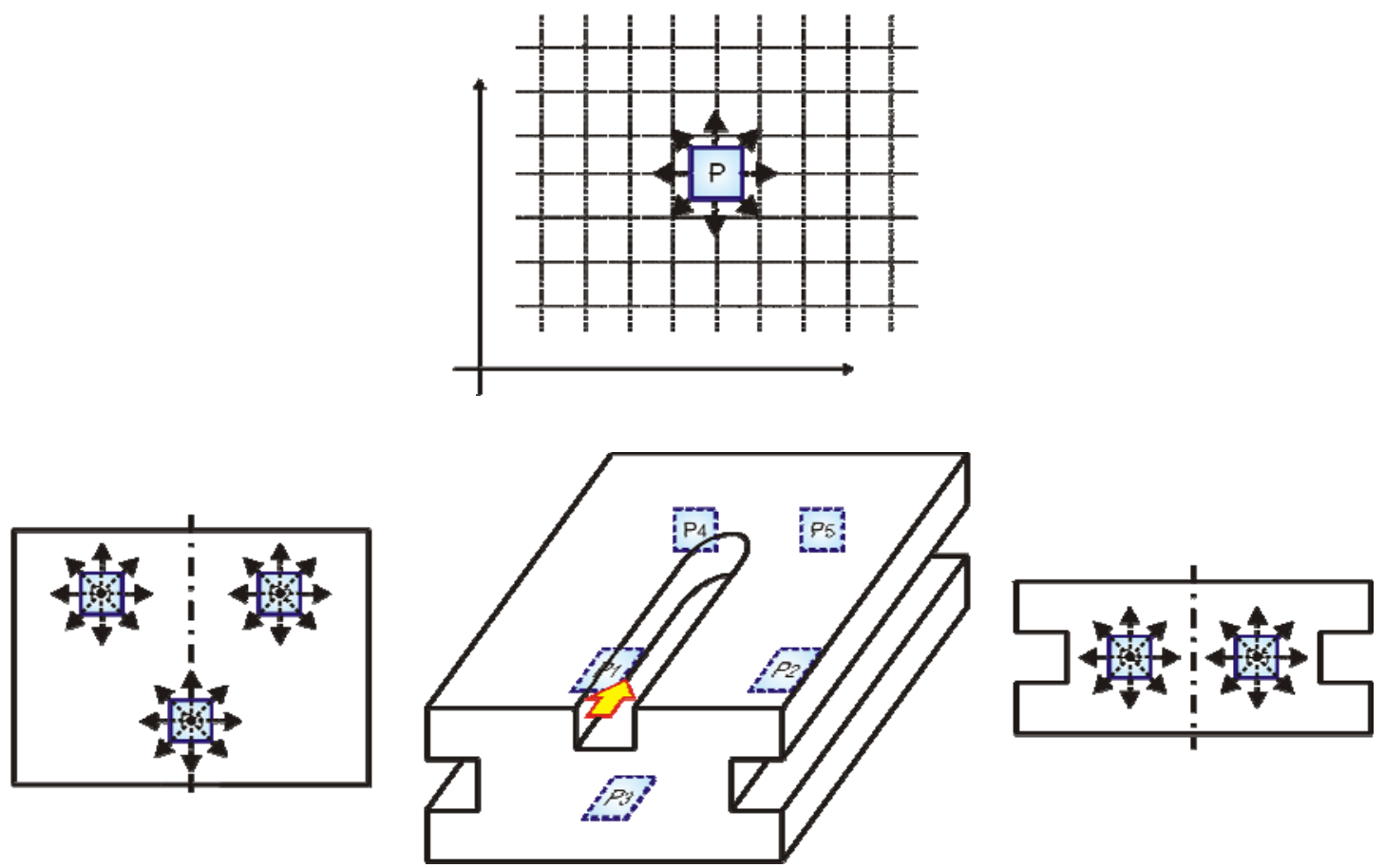

Slika 4.9. Strategija pronalaženja mogućih pozicija za pozicioniranje i stezanje

U dosadašnjim istraživanjima se nije vodila briga o mogućim kolizijama i nepravilnostima koje se mogu desiti u fazi planiranja koncepcije pribora. 
Jednim delom to je uzrokovala činjenica da su delovi uvek bili pravilnog prizmatičnog oblika.

U ovom prilazu posebna pažnja se mora obratiti na odgovarajuća ograničenja, tj. na pravilno definisanje površine preko koje će se izvesti pozicioniranje. Prvo - na pravilan broj oduzetih stepeni slobode, sa tačno određenim brojem elemenata za pozicioniranje (slika 4.10) i na eleminaciju postavljanja elementa za pozicioniranje na površinu koja ne postoji, a pripada ravni površine za pozicioniranje (slika 4.11).
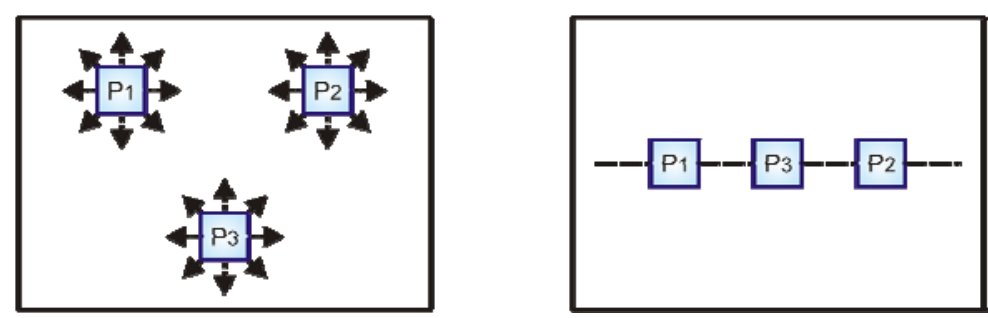

Slika 4.10. Postavljanje elemenata za pozicioniranje po pravoj (oduzimanje dva stepena slobode kretanja umesto tri stepena slobode kretanja)
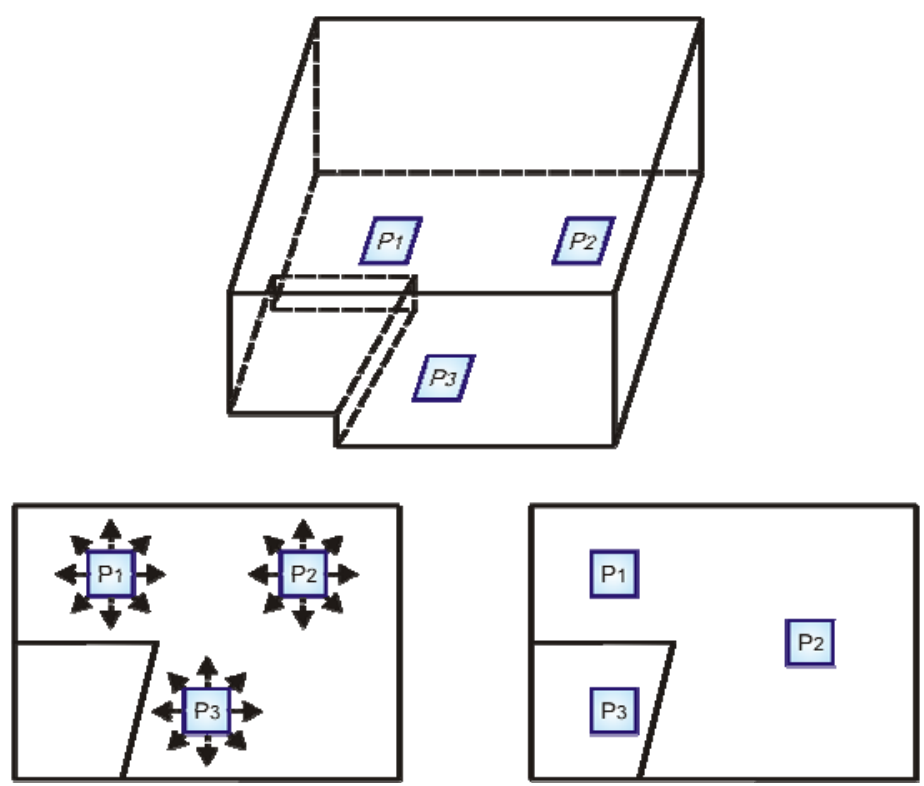

Slika 4.11. Postavljanje elementa za pozicioniranje na površini koja ne postoji

Inicijalna pozicija elemenata za stezanje se definiše kao pozicija koja se nalazi na površini i tački naspramnoj (paralelnoj) u odnosu na površinu i poziciju elemenata za pozicioniranje. U slučaju postavljanja $n$ elemenata za pozicioniranje, u prvoj inicijalnoj iteraciji upotrebiće se $n$ elemenata za stezanje. Broj i pozicija dejstva elemenata za stezanje se u kasnijim 
iteracijama menjaju, a sve u skladu sa intenzitetom reakcija oslonaca i sila stezanja.
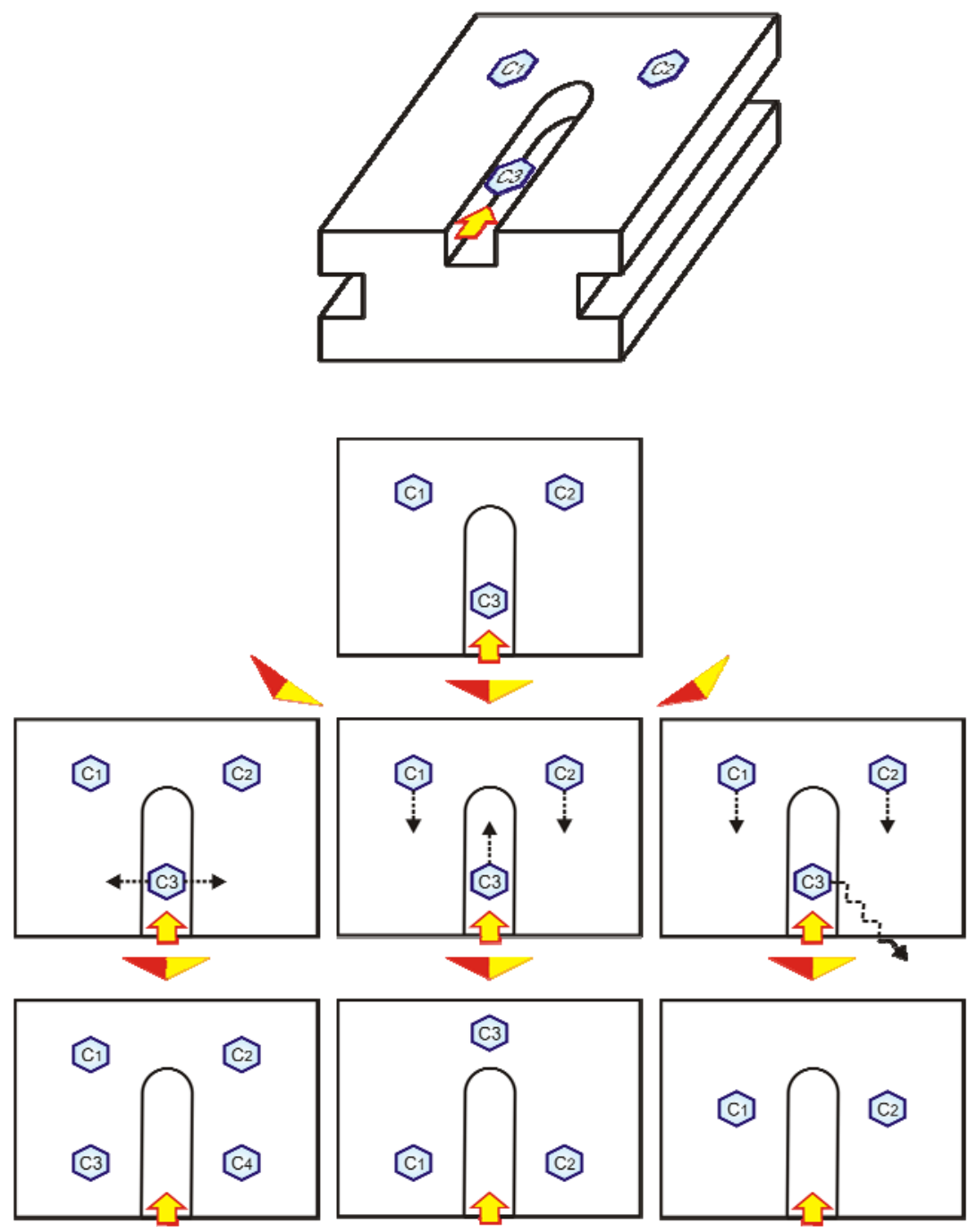

Slike 4.12. Kolizije između alata i elemenata za stezanje i mogući načini njihovog otklanjanja

Slično kao i pri definisanju mogućih šema za pozicioniranje, posebnu pažnju treba usmeriti na pojavu mogućih kolizija. Na slici 4.12 je dat primer kada se pozicija elementa za stezanje nađe na trajektori alata. $U$ takvim slučajevima je moguće rešiti problem na nekoliko načina. Bez obzira na način rešavanja problema, položaj elementa za stezanje mora biti promenjen, bilo zamenom postojećeg elementa sa dva nova, bilo samom promenom položaja elementa, bilo uklanjanjem elementa. Iz ovih razloga je potrebno tačno ograničiti deo površine za pozicioniranje i stezanje kako se ne bi desilo da se za optimalne pozicije elemenata za pozicioniranje i stezanje odaberu one na koje nije moguće postaviti fizički element. 
$\mathrm{Na}$ bazi karakteristika radnog predmeta, graničnih uslova i sila koje se javljaju u toku obrade vrši se proračun reakcija oslonaca i sila stezanja. Najvažnije informacije vezane za radni predmet su oblik, veličina, dimenzije i tolerancije. Parametar koji definiše granične uslove je koeficijent trenja koje se javlja između površina u kontaktu, u ovom slučaju između elemenata za pozicioniranje i radnog predmeta, sa jedne strane, i elemenata za stezanje i radnog predmeta, sa druge strane. Koeficijent trenja je zavisan od uslova kontakta materijala delova u kontaktu. Istraživanja su pokazala da su sile trenja koje nastaju kao posledica graničnih uslova veoma male, pa se njihov uticaj može zanemariti.

$\mathrm{Na}$ sklop radni predmet - pribor u toku mašinske obrade deluje pet različitih tipova sila: gravitaciona sila, sile rezanja, sile stezanja, sile reakcija oslonaca i sile trenja.

Pri definisanju pozicija elemenata za pozicioniranje i stezanje funkcija cilja $\left(F_{c}\right)$ je minimizovanje intenziteta sila koje deluju na radni predmet $u$ toku obrade kako bi deformacije radnog predmeta bile minimalne uz istovremeno zadovoljenje osnovnog zahteva da se radni predmet tokom procesa obrade ne sme pomeriti iz svog početnog položaja (nakon što se pozicionira i stegne).

$$
\operatorname{Min} F_{C}=\sum_{i=1}^{n} F_{i},(i=1,2, \ldots, n)
$$

Pri tome se moraju uzeti u obzir odgovarajuća ograničenja, a to su:

1. Jednačine ravnoteže - vektorski zbir svih sila i momenata koji deluju na radni predmet u toku obrade mora biti jednak nuli.

$$
\begin{aligned}
& \sum_{i=1}^{N} \vec{F}_{i}=0 \quad i=1,2, \ldots, n \\
& {\left[\sum_{i=1}^{n} F_{i}\right]_{X}=} 0 \\
& {\left[\sum_{i=1}^{n} F_{i}\right]_{Y}=0 } \\
& {\left[\sum_{i=1}^{n} F_{i}\right]_{Z}=0 } \\
& \sum_{i=1}^{N} \vec{M}_{i}=0 \quad i=1,2, \ldots, n
\end{aligned}
$$




$$
\begin{aligned}
& {\left[\sum_{i=1}^{n} M_{i}\right]_{X}=0} \\
& {\left[\sum_{i=1}^{n} M_{i}\right]_{Y}=0} \\
& {\left[\sum_{i=1}^{n} M_{i}\right]_{Z}=0}
\end{aligned}
$$

2. Reakcije oslonaca (sile elemenata za pozicioniranje) moraju imati tokom celokupnog procesa obrade pozitivnu vrednost, tj. moraju biti usmerene ka radnom predmetu.

$$
R_{i} \geq 0 \quad i=1,2, \ldots, n
$$

Negativna ili nulta vrednost bilo koje reakcije oslonaca znači da se radni predmet odvojio od elementa za pozicioniranje.

3. Sve sile moraju da deluju u nekoj tački na površini radnog predmeta.

$$
\begin{array}{ll}
\mathrm{x}_{\text {imin }} \leq \mathrm{x}_{\mathrm{i}} \leq \mathrm{x}_{\mathrm{imax}} & \mathrm{i}=1,2, \ldots, \mathrm{n} \\
\mathrm{y}_{\text {imin }} \leq \mathrm{y}_{\mathrm{i}} \leq \mathrm{y}_{\text {imax }} & \mathrm{i}=1,2, \ldots, \mathrm{n} \\
\mathrm{z}_{\text {imin }} \leq \mathrm{z}_{\mathrm{i}} \leq \mathrm{z}_{\text {imax }} & \mathrm{i}=1,2, \ldots, \mathrm{n}
\end{array}
$$

Rešenje gore navedenog problema je moguće u matričnom obliku. Vektor reakcija oslonaca se može napisati u obliku:

$$
R=\left[\begin{array}{l}
R_{i x} \\
R_{i y} \\
R_{i z}
\end{array}\right]
$$

gde su $R_{i x}, R_{i y}$ i $R_{i z}$ projekcije pojedinih komponetni sila reakcija oslonaca na ose $x, y$ i z. Pri tome su pojedine komponente sila u opštem slučaju jednake:

$$
\begin{aligned}
& R_{i x}=\left[\begin{array}{llllll}
R_{1 x} & R_{2 x} & R_{3 x} & R_{4 x} & R_{5 x} & R_{6 x}
\end{array}\right] \\
& R_{i y}=\left[\begin{array}{llllll}
R_{1 y} & R_{1 y} & R_{3 y} & R_{4 y} & R_{5 y} & R_{6 y}
\end{array}\right] \\
& R_{i z}=\left[\begin{array}{llllll}
R_{1 z} & R_{2 z} & R_{3 z} & R_{4 z} & R_{5 z} & R_{6 z}
\end{array}\right]
\end{aligned}
$$


Ubacivanjem jednačina (4.19), (4.20) i (4.21) u jednačinu (4.18) dobija se:

$$
R=\left[\begin{array}{llllll}
R_{1 x} & R_{2 x} & R_{3 x} & R_{4 x} & R_{5 x} & R_{6 x} \\
R_{1 y} & R_{2 y} & R_{3 y} & R_{4 y} & R_{5 y} & R_{6 y} \\
R_{1 z} & R_{2 z} & R_{3 z} & R_{4 z} & R_{5 z} & R_{6 z}
\end{array}\right]
$$

Vektor sile zemljine teže se može napisati u obliku:

$$
Q=\left[\begin{array}{l}
Q_{x} \\
Q_{y} \\
Q_{z}
\end{array}\right]
$$

gde su $Q_{i x}, Q_{i y}$ i $Q_{i z}$ projekcije pojedinih komponetni sile zemljine teže na ose $x$, y iz.

Vektor sila stezanja se može napisati u obliku:

$$
C=\left[\begin{array}{l}
C_{i x} \\
C_{i y} \\
C_{i z}
\end{array}\right]
$$

gde su $\mathrm{C}_{\mathrm{ix}}, \mathrm{C}_{\mathrm{iy}}$ i $\mathrm{C}_{\mathrm{iz}}$ projekcije pojedinih komponetni sila stezanja na ose $\mathrm{x}, \mathrm{y}$ i z. Pri tome su pojedine komponente sila jednake:

$$
\begin{aligned}
& C_{i x}=\left[\begin{array}{llllll}
C_{1 x} & C_{2 x} & C_{3 x} & C_{4 x} & C_{5 x} & C_{6 x}
\end{array}\right] \\
& C_{i y}=\left[\begin{array}{llllll}
C_{1 y} & C_{1 y} & C_{3 y} & C_{4 y} & C_{5 y} & C_{6 y}
\end{array}\right] \\
& C_{i z}=\left[\begin{array}{llllll}
C_{1 z} & C_{2 z} & C_{3 z} & C_{4 z} & C_{5 z} & C_{6 z}
\end{array}\right]
\end{aligned}
$$

Ubacivanjem jednačina (4.25), (4.26) i (4.27) u jednačinu (4.24) dobija se:

$$
C=\left[\begin{array}{llllll}
C_{1 x} & C_{2 x} & C_{3 x} & C_{4 x} & C_{5 x} & C_{6 x} \\
C_{1 y} & C_{2 y} & C_{3 y} & C_{4 y} & C_{5 y} & C_{6 y} \\
C_{1 z} & C_{2 z} & C_{3 z} & C_{4 z} & C_{5 z} & C_{6 z}
\end{array}\right]
$$

U gore navedenim jednačinama nepoznate veličine su reakcije oslonaca $\left(R_{i}\right)$ i odgovarajuće sile stezanja $\left(C_{i}\right)$, kao i njihove pozicije (vektori položaja). U najnepovoljnijem slučaju broj nepoznatih je 24, a samo je 6 jednačina ravnoteže. U najpovoljnijem slučaju broj nepoznatih je 8 , a broj jednačina ravnoteže je 6 . Kao što se vidi, broj nepoznatih promenljivih je mnogo veći nego broj jednačina ravnoteže. Da li je sistem jednačina rešiv? 
Rešenje ovakvog sistema jednačina je moguće izvesti uz pomoć genetskog algoritma. Genetski algoritam je heuristička metoda optimizacije i ubraja se u metode usmerenog slučajnog pretraživanja prostora rešenja (guided random search techniques) u potrazi za globalnim optimumom. Snaga genetskih algoritama leži u činjenici da su oni sposobni da odrede položaj globalnog optimuma u prostoru s više lokalnh ekstrema, u tzv. višemodalnom prostoru. Klasične determinističke metode će se uvek kretati prema lokalnom optimumu (minimumu ili maksimumu), pri čemu on može biti i globalni, ali to se ne može videti iz dobijenih rezultata. Genetski algoritmi nisu zavisni od inicijalne pozicije pretraživanja i svojim postupkom pretraživanja mogu da lociraju globalni optimum određene funkcije cilja s velikom verovatnoćom (slika 4.13.) [224].

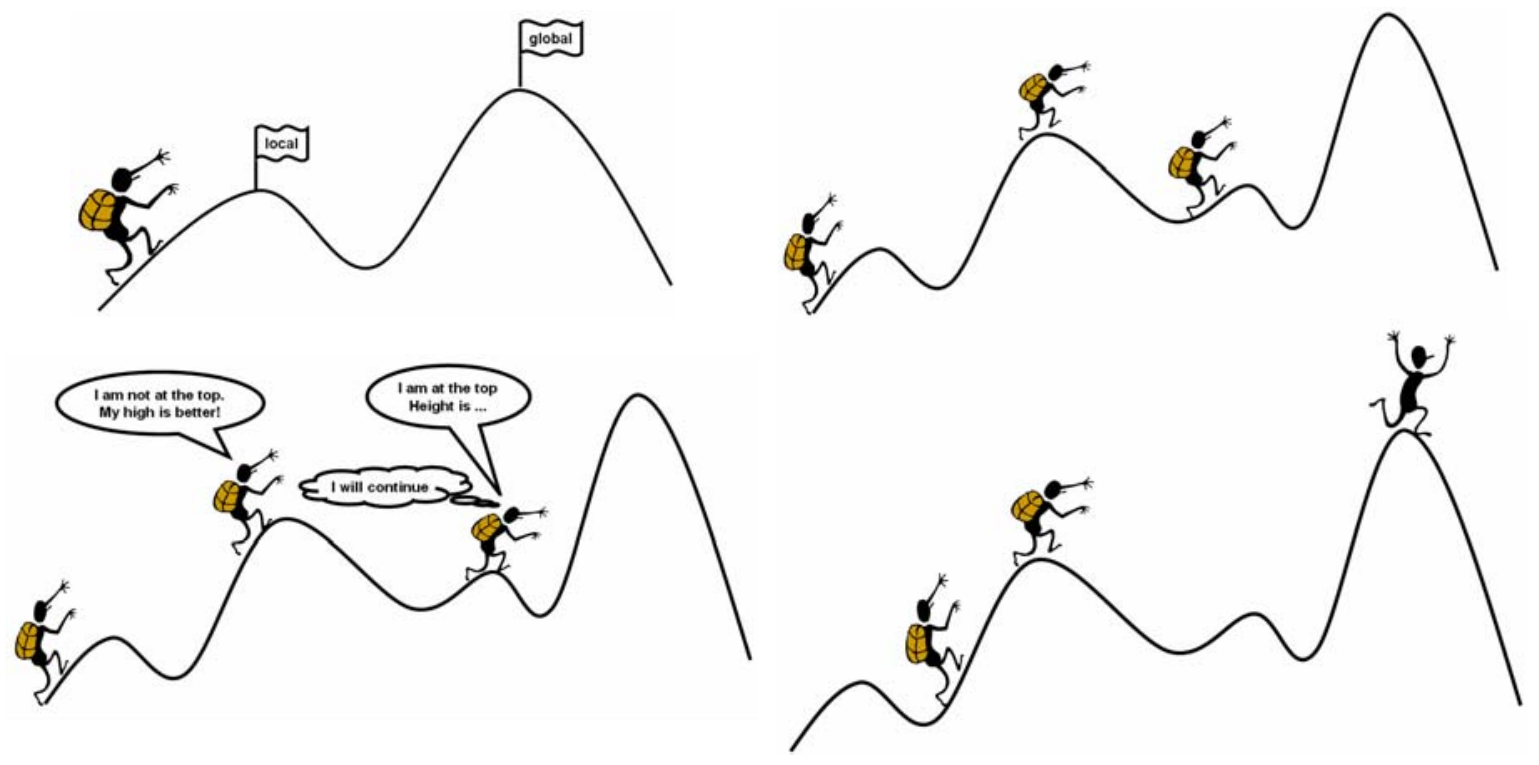

Slika 4.13. Genetski algoritmi - traženje globalnog optimuma

Matematički model predstavlja osnovu za reprodukciju, dok algoritam kontroliše proces reprodukcije i opstanak objekata koji se nadmeću u potrazi za optimalnim rešenjem. Algoritam radi sa skupom promenljivih veličina. $\mathrm{Na}$ njih se primenjuju genetski operatori, a zatim se vrši njihova procena. Opstanak zavisi od vrednosti koju će ova funkcija vratiti. Favorizuje se opstanak najjačih. Genetski operatori obezbeđuju da potomci budu slični, ali ne i identični sa roditeljima. Na taj način se populaciji omogućava da evoluira do rešenja koja nisu bila prisutna u početnom skupu objekata. Ovakav distribuirani, evolucioni pristup omogućava genetskim algoritmima da ne upadnu u zamku lokalnih optimuma. On je u stanju da identifikuje rešenja bliska globalnim optimumima ili identična sa njima. Genetski algoritmi su zasnovani na principima evolucije. Osnovni objekat genetskih algoritama je 
organizam, a njegova iskorišćenost se naziva fitnes (fitness) - tabela 4.2. Osnovni operatori koji se primenjuju na organizme su ukrštanje, mutacija i selekcija. Ukrštanje, mutacija i selekcija čine jednu generaciju koja je ekvivalentna jednoj iteraciji u tradicionalnim optimizacionim tehnikama.

\begin{tabular}{|c|c|}
\hline 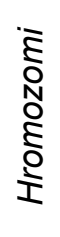 & $\begin{array}{l}\text { Genetski algoritam radi sa parametrima koji su binarno kodirani u hromozome. } \\
\text { Hrozomom može da predstavi skup parametara proizvoljne dužine - dovoljno je da } \\
\text { hromozom sadrži dovoljan broj bita. Genetski algoritmi rade sa populacijom } \\
\text { sastavljenom od fiksnog broja jedinki ili organizama. Svaku jedinku karakteriše njen } \\
\text { hromozom u vidu gena koji nosi informacije o osobinama jedinke. }\end{array}$ \\
\hline 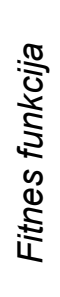 & $\begin{array}{l}\text { Genetski algoritmi zahtevaju neku kvantitativnu meru korisnosti, tj. ispravnosti } \\
\text { predloženog rešenja (u ovom slučaju hromozoma). Ovu meru daje fitnes funkcija. } \\
\text { Fitnes funkciji se prosleđuje skup parametara kodiran u određenom hromozomu, a } \\
\text { ona vraća meru njegove korisnosti. Na hromozome se, u zavisnosti od dobijene } \\
\text { vrednosti fitnes funkcije, primenjuju različiti operatori u cilju favorizovanja hromozoma } \\
\text { koji su bliži rešenju problema. }\end{array}$ \\
\hline 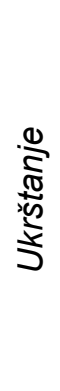 & $\begin{array}{l}\text { Ukrštanje predstavlja razmenu genetskog materijala između dva organizma } \\
\text { populacije. Prvi korak je deoba hromozoma na dva dela. Oba hromozoma se dele na } \\
\text { slučajno izabranom mestu. Sledeći korak je izmena bita (genetičkog materijala) koji su } \\
\text { se podelili. Zatim se delovi ponovo spajaju, čime se dobijaju dva nova hromozoma, sa } \\
\text { novim skupovima parametara. Neki od parametara oba hromozoma sadrže vrednosti } \\
\text { koje nisu bile prisutne u roditeljskim hromozomima. Ova mala razlika između roditelja i } \\
\text { potomka je vitalna za rad genetskih algoritama, jer se njom omogućava da selekcija } \\
\text { vodi populaciju u željenom pravcu. }\end{array}$ \\
\hline 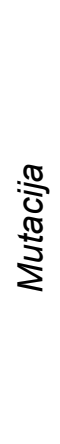 & $\begin{array}{l}\text { Operator mutacije je unarni operator, tj. radi sa pojedinačnim hromozomima i na } \\
\text { slučajan način menja vrednosti njihovih bita. Ova promena može biti veoma } \\
\text { destruktivna za dobre hromozome, ali je neophodna kako populacija ne bi evoluirala } \\
\text { suviše brzo - na ovaj način se izbegava konvergencija ka lokalnom optimumu (efekat } \\
\text { „konvergencija populacije“). Prvi korak je izbor slučajne lokacije koja će mutirati. } \\
\text { Vrednost bita se menja, tj. bit se invertuje i hromozom se vraća u populaciju. Mutacija } \\
\text { može da ima drastične efekte na promenu skupa parametara povezanih sa datim } \\
\text { hromozomom, što može dovesti do pada vrednosti fitnes funkcije. Broj hromozoma } \\
\text { koji u jednoj generaciji mutira je obrnuto proporcionalan broju hromozoma u populaciji. }\end{array}$ \\
\hline 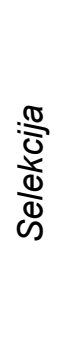 & $\begin{array}{l}\text { Operator selekcije treba da obezbedi da broj potomaka u narednoj generaciji bude } \\
\text { srazmeran sa rezultatom koji za svaki organizam vraća fitnes funkcija. Najpopularnija } \\
\text { metoda selekcije je metoda „ruleta“. Svakom hromozomu se dodeljuje površina u } \\
\text { krugu za rulet koja je srazmerna njegovoj fitnes funkciji. Za svako slobodno mesto u } \\
\text { novoj generaciji se zavrti krug i izvlači po jedan organizam koji zatim zauzima to } \\
\text { mesto. Na taj način se favorizuju bolji koji će u svakoj narednoj generaciji zauzimati } \\
\text { sve više mesta u populaciji. }\end{array}$ \\
\hline
\end{tabular}

Tabela 4.2. Globalne karakteristike elemenata genetskih algoritama 
Opšta struktura genetskog algoritma i njegov pseudokod su prikazani na slici 4.14.
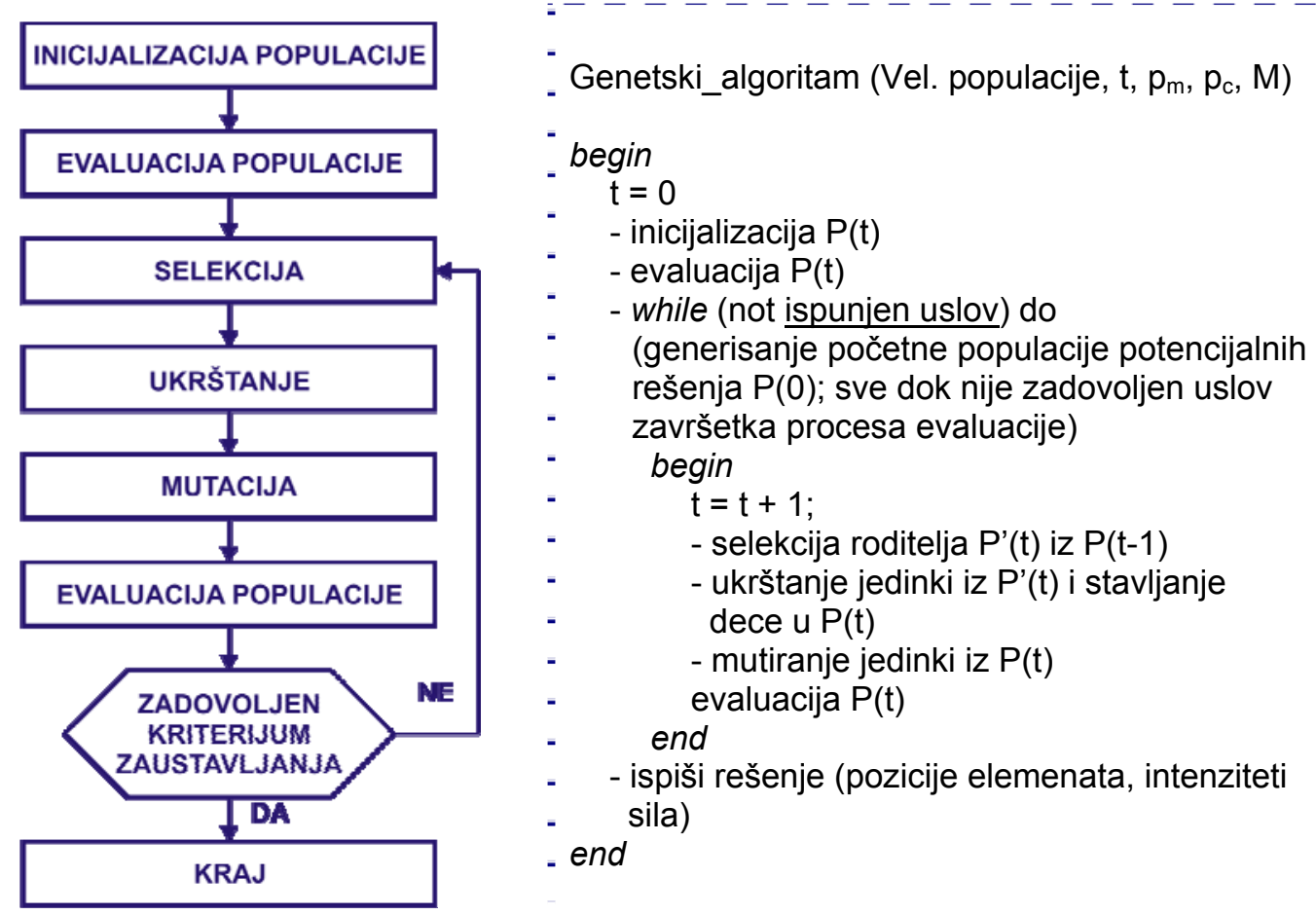

Slika 4.14. Struktura i pseudokod genetskog algoritma

Optimizacija položaja elemenata za stezanje i pozicioniranje se vrši uz pomoć genetskog algoritma. Prilikom inicijalizacije genetskog algoritma formira se početna populacija jedinki. U konkretnom slučaju nepozante promenljive su pozicije i intenziteti sila stezanja, i pozicije i intenziteti sila pozicioniranja (reakcije oslonaca). Ove sile treba da budu minimalne kako bi se radni predmet što manje deformisao. Kombinacije različitih varijanti ovih komponenti čine prostor rešenja. Genetski algoritam se koristi za pretraživanje ovog prostora kako bi pronašao optimalan raspored i intenzitet sila. Svako moguće rešenje se predstavlja kao „hromozom“, nastavljeni niz od komponenti, pri čemu se svaka pojedina komponenta naziva "gen“. Modul za definisanje koncepcije pribora odabira hromozome koji će biti reprodukovani na osnovu njihovih mera odstupanja. Do novih koncepcijskih rešenja za pribor, koja imaju manje odstupanje (intenzitet sile) od prethodnog rešenja, dolazi se primenom genetskih operacija, poput „ukrštanja“ i „mutacije“. Ovaj ciklus operacija ponavlja se kroz nekoliko „generacija“, sve dok se ne dobiju položaji i intenziteti sila (sila stezanja i reakcija oslonaca) sa minimalnim vrednostima (povoljnom merom odstupanja), tj. dok se ne zadovolji kriterijum zaustavljanja. $\mathrm{Na}$ izlazu iz ovog modula se dobijaju optimalne pozicije elemenata za pozicioniranje i stezanje (slika 4.15.). 


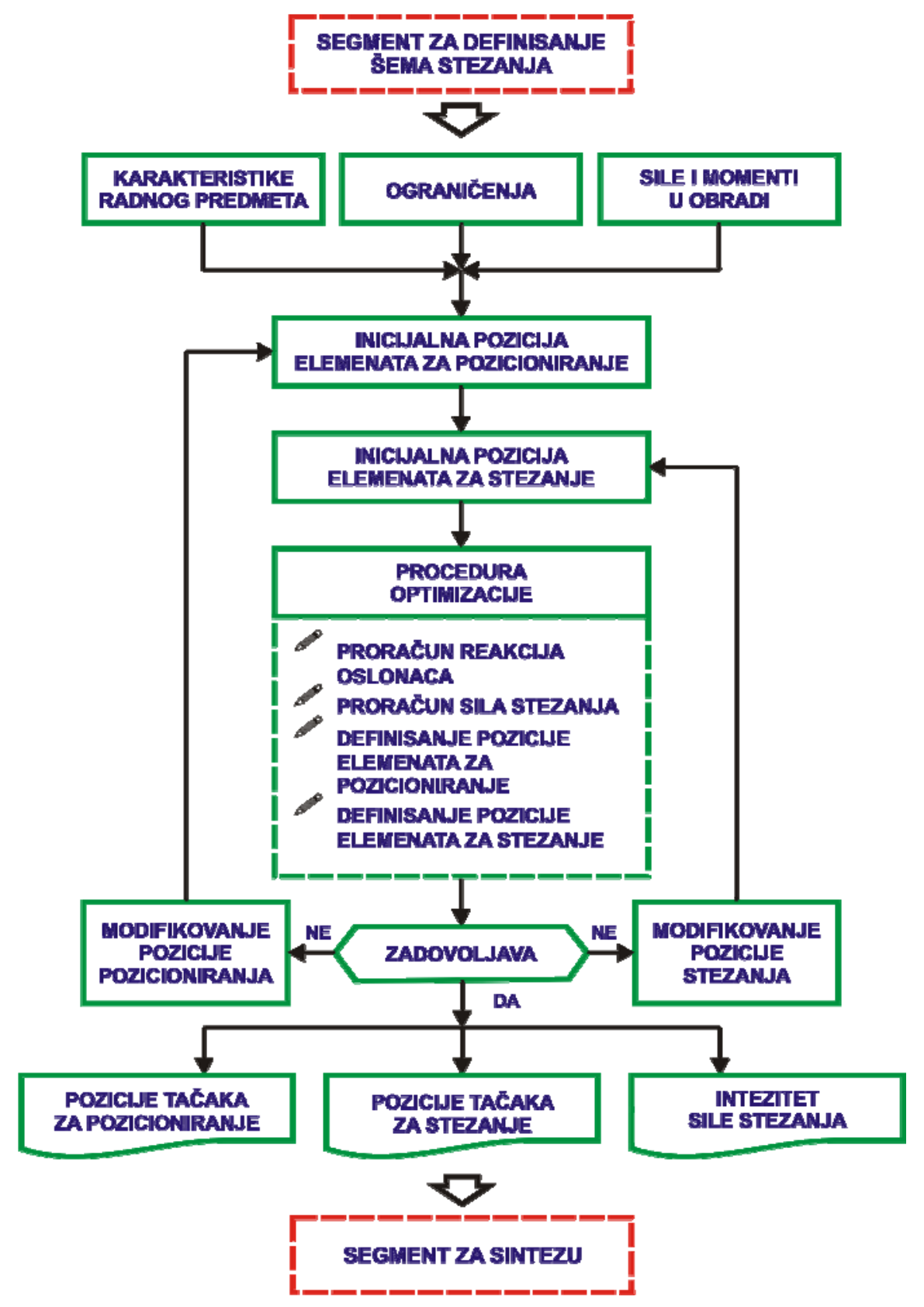

Slika 4.15. Struktura modula za determinisanje tačaka pozicioniranja i stezanja

\subsubsection{Modul za sintezu pribora}

Problem projektovanja pribora tj. izbora adekvatnih elemenata pribora koji će se upotrebiti za komponovanje nove konstrukcije pribora najčešće se sastoji $u$ tome što su oni slabo strukturirani, tj. ne podležu matematičkom modeliranju i formalizaciji. Standardni algoritamski pristup je praktično 
neupotrebljiv u rešavanju ovakvih problema, zato je zgodno pribeći inteligentnom izboru odgovarajućih elemenata pribora.

U okviru modula za sintezu pribora (slika 4.16.) vrši se izbor potrebnih elemenata pribora, a na osnovu prethodno unetih ulaznih informacija i mogućih šema pozicioniranja i stezanja, dobijenih u prethodnom modulu sistema. U okviru ovog segmenta sistema vrši se izbor svih potrebnih elemenata pribora iz pojedinih funkcionalnih grupa elementa (tabela 4.2).

\begin{tabular}{|c|c|}
\hline $\begin{array}{l}\text { Funkcionalna grupa } \\
\text { elemenata pribora }\end{array}$ & Osnovna karakteristika \\
\hline Elementi za pozicioniranje & $\begin{array}{l}\text { Jednoznačno definisanje položaja radnog predmeta u } \\
\text { priboru, dovođenje radnog predmeta u korektan i } \\
\text { konačan položaj u priboru, ograničavanje stepeni } \\
\text { slobode radnom predmetu (deo ili svi) tako da se } \\
\text { potrebna obrada može pravilno izvršiti. }\end{array}$ \\
\hline Elementi za stezanje & $\begin{array}{l}\text { Obezbeđivanje stabilanog kontakta sa elementima za } \\
\text { pozicioniranje, onemogućavanje pomeranja radnog } \\
\text { predmeta od površina za pozicioniranje u toku procesa } \\
\text { obrade, uprkos dejstvu svih sila koje deluju na njega. }\end{array}$ \\
\hline Elementi tela pribora & $\begin{array}{l}\text { Prihvatanje i sjedinjavanje svih ostalih elemenata i } \\
\text { primanje svih opterećenja koja dejstvuju na radni } \\
\text { predmet za vreme obrade. }\end{array}$ \\
\hline Elementi za vođenje alata & $\begin{array}{l}\text { Vođenje alata tokom procesa obrade u cilju dobijanja } \\
\text { tražene mere u zahtevanim tolerancijama obrade. }\end{array}$ \\
\hline $\begin{array}{l}\text { Elementi za podešavanje } \\
\text { položaja alata }\end{array}$ & $\begin{array}{l}\text { Podešavanje položaja alata u odnosu na položaj radnog } \\
\text { predmeta u cilju dobijanja tražene mere u zahtevanim } \\
\text { tolerancijama obrade, podešavanje položaja alata u } \\
\text { odnosu na površinu koja se obrađuje na radnom } \\
\text { predmetu. }\end{array}$ \\
\hline Elementi za vezu & Međusobno spajanje ostalih grupa elemenata pribora. \\
\hline $\begin{array}{l}\text { Nadogradni } \\
\text { elementi/elementi za } \\
\text { premošćavanje visinskih i } \\
\text { dužinskih rastojanja }\end{array}$ & $\begin{array}{l}\text { Premošćavanje određenih rastojanja u bilo kom pravcu } \\
\text { sa ciljem dobijanja zaokružene celine pribora. }\end{array}$ \\
\hline $\begin{array}{l}\text { Nadogradni } \\
\text { elementi/elementi za } \\
\text { manipulisanje priborom }\end{array}$ & $\begin{array}{l}\text { Manipulisanje priborom pri postavljanju/skidanju pribora } \\
\text { sa mašine alatke, transportu i sl. }\end{array}$ \\
\hline
\end{tabular}

Tabela 4.2 Osnovne karakteristike pojedinih funkcionalnih grupa elemenata pribora 


\begin{tabular}{|l|l|}
\hline $\begin{array}{l}\text { Nadogradni elementi/elementi za } \\
\text { naslon na mašinu alatku }\end{array}$ & $\begin{array}{l}\text { Manipulisanje priborom pri postavljanju/skidanju } \\
\text { pribora sa mašine alatke, transportu i sl. }\end{array}$ \\
\hline $\begin{array}{l}\text { Nadogradni elementi / elementi } \\
\text { za pozicioniranje pribora na } \\
\text { mašini alatki }\end{array}$ & $\begin{array}{l}\text { Jednoznačno definisanje položaja pribora na } \\
\text { radnom stolu mašine alatke. }\end{array}$ \\
\hline $\begin{array}{l}\text { Nadogradni elementi/elementi za } \\
\text { stezanje pribora za mašinu } \\
\text { alatku }\end{array}$ & Fiksiranje pribora za radni sto mašine alatke. \\
\hline $\begin{array}{l}\text { Nadogradni elementi/sigurnosni } \\
\text { elementi }\end{array}$ & $\begin{array}{l}\text { Postavljanje radnog predmeta u ispravan položaj u } \\
\text { priboru. }\end{array}$ \\
\hline $\begin{array}{l}\text { Nadogradni elementi/pokretni } \\
\text { elementi }\end{array}$ & $\begin{array}{l}\text { Dovođenje radnog predmeta u istom (jednom) } \\
\text { stezanju u novi radni položaj u odnosu na alat } \\
\text { translatornim pomeranjem radnog predmeta. }\end{array}$ \\
\hline $\begin{array}{l}\text { Nadogradni elementi/okretni } \\
\text { elementi }\end{array}$ & $\begin{array}{l}\text { Dovođenje radnog predmeta u istom (jednom) } \\
\text { stezanju u novi radni položaj u odnosu na alat } \\
\text { obrtnim pomeranjem radnog predmeta. }\end{array}$ \\
\hline
\end{tabular}

Tabela 4.2 (nastavak) Osnovne karakteristike pojedinih funkcionalnih grupa elemenata pribora

Osnovna ideja kod produkcionih sistema je u tome da se na problem, opisan podacima u radnoj memoriji, iterativno primenjuju pravila iz baze znanja. Ukoliko se opis problema „podudara“ sa IF-klauzulama jednog ili više pravila, rešenje problema se može naći u THEN-klauzuli tog/tih pravila. Mehanizam za zaključivanje ima zadatak da pronađe odgovarajuće znanje u bazi znanja. On je lociran između baze znanja, sa jedne strane, i interfejsa, sa druge strane. Mehanizam zaključivanja sadrži u sebi poseban program, tzv. interpretator pravila (rule interpreter) koji je zadužen za procesiranje i interpretaciju produkcionih pravila $u$ toku rada sistema. $U$ procesu zaključivanja, na osnovu inicijalnih informacija u radnoj memoriji (radna memorija sadrži trenutne podatke vezane za pribor za koji sistem pokušava da nađe adekvatne elemente) i znanja koje se nalazi u bazi znanja, mehanizam zaključivanja pokušava da pronađe adekvatne elemente pribora. Inicijalni podaci koji se smeštaju u radnu memoriju dobijaju se na osnovu ulaznih informacija i informacija generisanih u okviru modula za optimizaciju 
konstrukcije pribora. Mehanizam zaključivanja zatim primenjuje na te podatke znanje iz baze znanja, generišući nove podatke $u$ radnoj memoriji. Time se skup podataka u radnoj memoriji proširuje. Novo stanje u radnoj memoriji može da bude dovoljno za izbor elemenata pribora i u tom slučaju se proces zaključivanja završava. U protivnom, prošireni skup podataka se ponovo obrađuje korišćenjem znanja iz baze znanja, što dovodi do nove promene stanja u radnoj memoriji. Proces se iterativno nastavlja dok se ne dođe do stanja u radnoj memoriji koje je dovoljno za izbor elemenata ili dok se ne pokaže da rešenje nije moguće dobiti. Kada se dobije više karakterističnih rešenja elemenata pribora za posmatranu operaciju obrade datog radnog predmeta, vrši se sortiranje mogućih rešenja. Kao funkcije cilja moguće je postaviti različite parametre. Svakom parametru se dodaje određeni težinski koeficijent sa ciljem dobijanja što realnijih rezultata, tako da je funkcija cilja oblika:

$F_{C}=a_{1} B_{1}+a_{2} B_{2}+\ldots a_{k} B_{k}$, pri čemu su:

- $a_{i}$ - težinski koeficijenti;

- $B_{i}$ - parametri optimizacije.

Ukoliko u bazi podataka postoje svi potrebni elementi, na izlazu iz ovog segmenta dobijaju se odgovarajući elemenati pribora na osnovu kojih se u okviru modula za izlazne informacije vrši sinteza pribora. Nepostojanje potrebnog elementa ili više njih iziskuje projektovanje nepostojećeg elementa (elemenata) i nabavku/izradu elementa (elemenata). Potrebno je takođe izvršiti memorisanje elementa u bazu podataka i pridružiti mu odgovarajuća produkciona pravila za njegov izbor. 


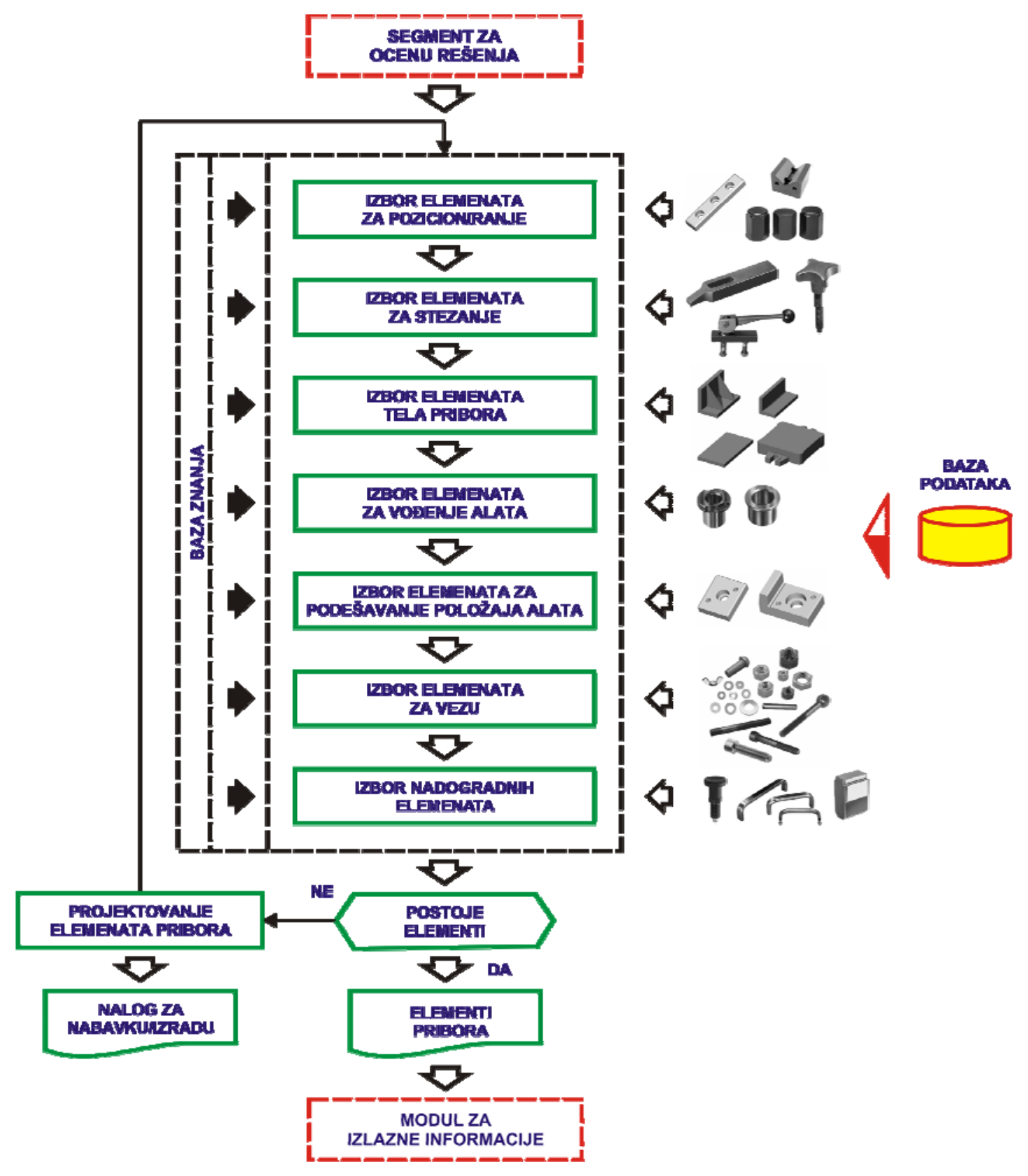

Slika 4.16. Struktura modula za sintezu pribora

\subsubsection{Modul za izlazne informacije}

Ulaz u modul za izlazne informacije (slika 4.17) predstavljaju informacije o elementima pribora koje se dobijaju na izlazu iz modula za sintezu pribora.

U prvom koraku se vrši sastavljanje pribora uz podršku odgovarajuće baze podataka, tj. njenih sastavnih delova - datoteka elemenata pribora iz svih funkcionalnih grupa. Nakon sinteze pribora izvodi se analiza dobijenog 
konstruktivnog rešenja pribora. Ova analiza podrazumeva detektovanje i otklanjanje mogućih kolizija. Uzroci kolizija u toku procesa obrade mogu biti višestruki, a jedan od uzroka može biti pribor. Usled toga je neophodno nakon projektovanja pribora izvršiti analizu mogućih kolizija i preduzeti odgovarajuće mere kako bi se iste otklonile. Mogu se identifikovati tri vrste kolizija:

- kolizije između sastavnih elemenata pribora,

- kolizije između elemenata pribora i radnog predmeta,

- kolizije između alata i elemenata pribora.

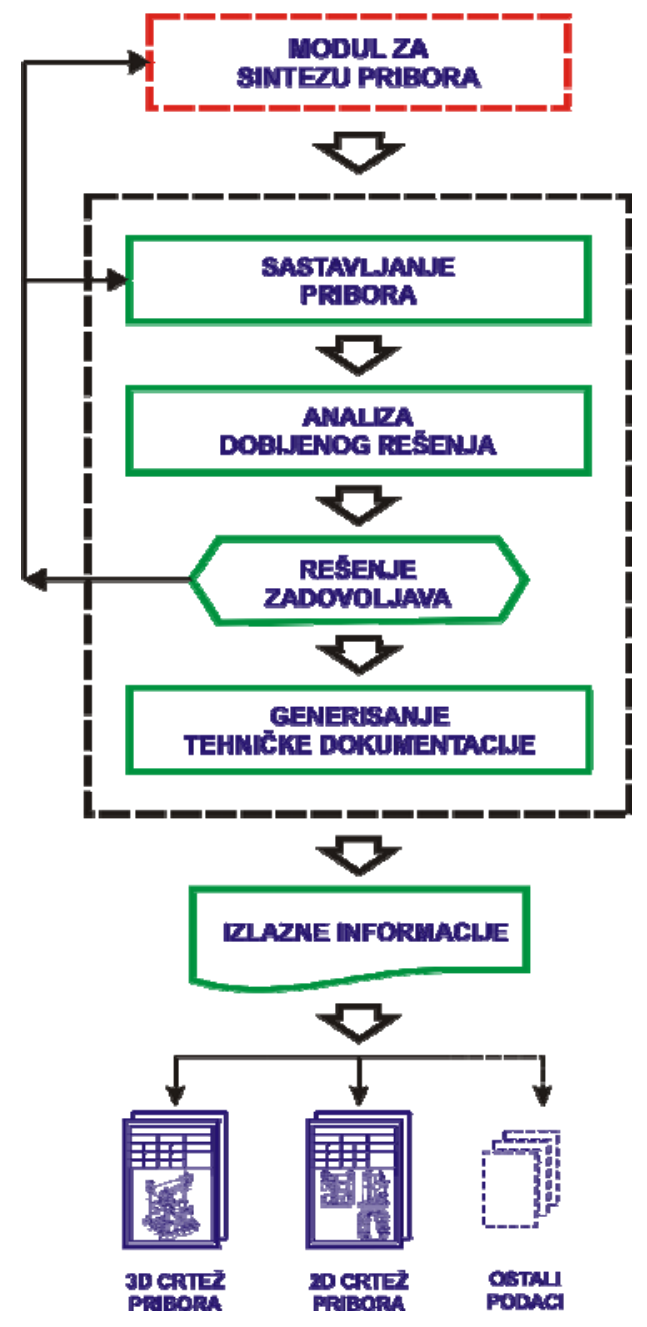

Slika 4.17. Struktura modula za izlazne informacije

Kolizije između sastavnih elemenata pribora mogu predstavljati veliki problem u procesu montaže pribora kada monter uzima konkretne elemente $\mathrm{i}$ raspoređuje in na odgovarajuće mesto, jedne u odnosu na druge i u odnosu na radni predmet. 
Kolizije između elemenata pribora i radnog predmeta mogu direktno uticati na nemogućnost izvršenja zahtevanih operacija obrade, a ogledaju se u nemogućnosti postavljanja i vađenja radnog predmeta iz pribora. Takođe, postoji mogućnost da se radni predmet postavi u pribor u dva ili više položaja, što omogućava da se operacija obrade izvede, ali na pogrešnom mestu.

Do kolizija između alata i sastavnih elemenata pribora može doći u slučaju postavljanja elemenata pribora duž trajektorije kretanja alata u toku obrade. Ovo može imati za posledicu oštećenje alata ili elemenata pribora, a u nekim slučajevima može dovesti i do loma alata i elemenata pribora, oštećenja mašine i ostalih delova obradnog sistema, povreda poslužioca itd.

Ukoliko nije moguće dobiti rešenje pribora koje zadovoljava, potrebno je ponovno ulaženje u modul za sintezu pribora i izbor ili projektovanje dodatnih elemenata pribora.

Nakon što se formira finalno rešenje pribora, generišu se potrebne izlazne informacije - crteži pribora i odgovarajuća sastavnica. Ukoliko se javi potreba za još nekim dodatnim informacijama, one se generišu u okviru ovog modula. 


\section{FUNKCIONISANJE PROGRAMSKOG REŠENJA SISTEMA}

\subsection{UVODNE NAPOMENE}

Prvi korak u razvoju programskog rešenja sistema jeste definisanje zahteva koji se postavljaju pred sistem. Mogu se identifikovati sledeći zahtevi:

- stvaranje konkretnog programskog rešenja sa jednostavnim i lakim korisničkim interfejsom, koji se brzo može naučiti i koji odgovara postojećim pravilima pri korišćenju savremenih operativnih i programskih sistema,

- brz i efikasan rad programa bez zastoja prilikom obrade podataka i formiranja prikaza,

- univerzalnost primene i jednostavnost učenja,

- mogućnost skladištenja potrebnih informacija za projektovanje, generisanja željenih instrukcija u okviru sistema - programskog koda i modeliranja potrebnih elemenata i sklopova.

Pri tome je jako bitno ispitati mogućnost upotrebe jednog ili više međusobno integrisanih programskih sistema koji bi omogućavali realizaciju postavljenog cilja. Ovde je uzeta u obzir i mogućnost integracije ovih eksternih programskih sistema, kroz tzv. OLE ${ }^{10}$ automatizaciju. U formi standardizovanih funkcijskih poziva, OLE definiše osnovne okvire za međusobnu komunikaciju različitih programa. Ovaj vid automatizacije omogućuje da jedan program upravlja drugim. Pri tome se program koji manipuliše objektima u okviru drugog programa naziva klijentom, dok se program koji svoju internu strukturu

${ }^{10}$ OLE (Object Linking and Embedding) - povezivanje i ugrađivanje objekata 
stavlja na raspolaganje eksternom sistemu naziva serverom. Objekti koji su putem OLE-a stavljeni na raspolaganje eksternim programskim sistemima nazivaju se objektima automatizacije.

\subsection{PROGRAMSKO REŠENJE SISTEMA}

Sistematizacija osnovnih podloga za razvoj strukture sistema, definisanje koncepcije sistema, kao i izbor programske podrške opšte namene za ravoj programskog rešenja predstavljaju početni korak u razvoju sistema automatizovanog projektovanja i optimizacije konstrukcije pribora. U narednom poglavlju navodi se opis rada sistema kroz vizuelno objašnjenje rada ključnih segmenata i modula.

Pokretanjem programa započinje interaktivni rad između računara i projektanta putem formi. $U$ toku rada korisnik odgovara na postavljena pitanja upisivanjem odgovarajućih podataka u odgovarajuća polja i/ili izborom odgovarajućih podataka iz odgovarajućih polja.

$\mathrm{Na}$ prvoj formi koja se otvara pokretanjem sistema (slika 5.1), projektantu su date tri opcije:

- „projektovanje pribora“ - proces optimizacije i projektovanja konstrukcije pribora,

- „baza podataka“ - proces ažuriranja baze podataka,

- „baza znanja“ - proces ažuriranja baze znanja.

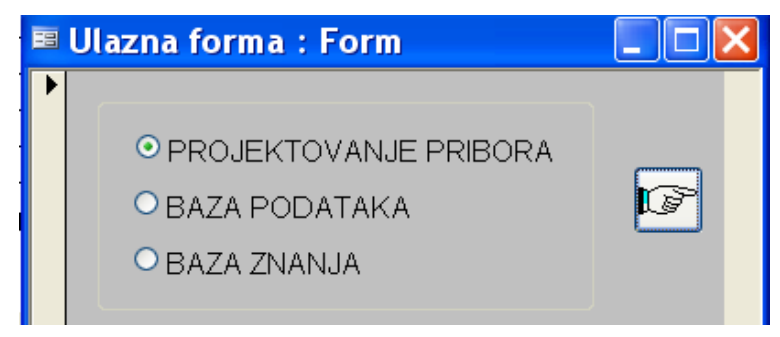

Slika 5.1. Ulazna forma u sistemu automatizovanog projektovanja pribora

\subsubsection{Rešenje baze podataka}

Baza podataka obezbeđuje funkcionisanje sistema u smislu kvalitetnog izvršavanja njegovih osnovnih funkcija, pretraživanja i ažuriranja podataka. Takođe, ona predstavlja osnovnu sistemsku podršku za projektovanje novih rešenja, obezbeđujući sve neophodne informacije. 
Za uspešno funkcionisanje celokupnog sistema baza podataka mora da poseduje određene datoteke: datoteku pribora, datoteku radnih predmeta i datoteku elemenata pribora.

Datoteke je pogodno organizovati u obliku tabela, tako da kolone predstavljaju postojeće pribore, radne predmete i elemente pribora, a vrste njihove karakteristike. Tabele se mogu koristiti $u$ automatizovanom sistemu izbora elemenata pribora kao sredstvo formalizacije procesa izbora jedne varijante iz skupa mogućih i kao sredstvo automatizacije programiranja potrebnih zadataka.

Datoteka pribora sadrži informacije o svim gotovim konstruktivnim rešenjima pribora uskladištenim u njoj. Svaki pribor je jednoznačno definisan preko svoje identifikacione oznake. Neophodni podaci za svaki pribor su i operacija za koju je konstruisan pribor, naziv i oznaka mašine, ime i prezime projektanta, datum projektovanja i odgovarajuća napomena. Obavezan podatak je i identifikaciona oznaka radnog predmeta za koji je pribor projektovan pošto se preko nje uspostavlja veza sa datotekom radnih predmeta. $U$ datoteci pribora memorišu se i drugi podaci neophodni za izbor pribora (vreme eksploatacije i broj elemenata), kao i grafički podaci u obliku 2D i 3D crteža pribora.

U datoteci radnih predmeta figurišu svi radni predmeti za koje postoje konstruisani pribori. Za svaki radni predmet se daje identifikaciona oznaka (veza sa datotekom gotovih konstruktivnih rešenja pribora), naziv, veličina serije, naziv i kod operacije, 2D i 3D crtež radnog predmeta, kao i crtež (karta) operacije.

Datoteka elemenata pribora sadrži sve podatke 0 svakom pojedinačnom elementu pribora, neophodnom za projektovanje novih konstrukcija pribora. Informacije u ovoj datoteci se koriste za izbor elemenata pribora. Datoteka elemenata pribora sadrži identifikacionu oznaku svakog elementa, njegov naziv, pripadnost određenoj funkcionalnoj grupi i grupi elemenata, masu svakog elementa, njegovu cenu, broj identičnih elemenata pribora koji su na raspolaganju za projektovanje, 2D i 3D crteže elemenata. Ovi podaci su određeni za bilo koji element uskladišten u bazi podataka. U datoteci elemenata pribora moraju biti uskladišteni i geometrijski i ostali podaci (tehnološki, organizacioni, itd.). Ovi podaci su karakteristika svakog elementa ponaosob. Elementi koji pripadaju istoj funkcionalnoj grupi ili grupi elemenata nemaju isti broj podataka. Broj ovih podataka varira od elementa do elementa. Različiti elementi imaju različit oblik pa samim tim i geometrijske karakteristike. Takođe, različitim elementima se ostvaruju različite funkcije, pa se i broj ostalih podataka razlikuje od elementa do elementa. 
Glavni princip koji je korišćen pri modeliranju baze podataka jeste princip hijerarhijske dekompozicije sistema. Pri modeliranju pošlo se od zahteva koji će biti značajni budućim korisnicima. Identifikovani su sledeći potrebni procesi:

- ažuriranje baze podataka - proces koji obuhvata unos, menjanje i brisanje podataka iz baze,

- pretraživanje baze podataka - proces koji obezbeđuje mogućnost pretraživanja baze podataka po unapred postavljenim kriterijumima.

U skladu sa tim, prva forma (slika 5.2) koja se otvara pred korisnikom upravo mu daje izbor između dve prethodno pomenute opcije.

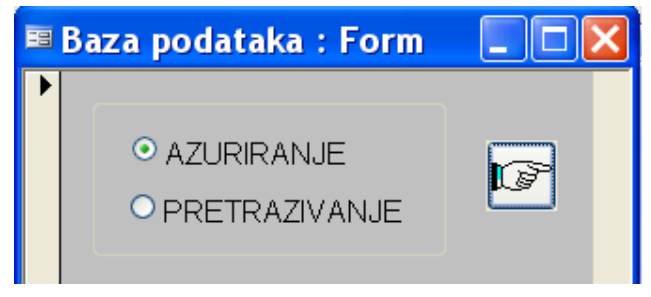

Slika 5.2. Izgled forme za izbor opcija - ažuriranja podataka ili pretraživanja baze podataka

\subsubsection{Ažuriranje baze podataka}

Ažuriranje baze podataka se odnosi na unos, menjanje ili brisanje podataka, vezanih za elemente pribora, gotova konstruktivna rešenja pribora i njima pripadajuće radne predmete. U skladu sa ovim, projektant se u sledećem koraku opredeljuje nad kojim delom baze podataka vrši ažuriranje (slika 5.3).

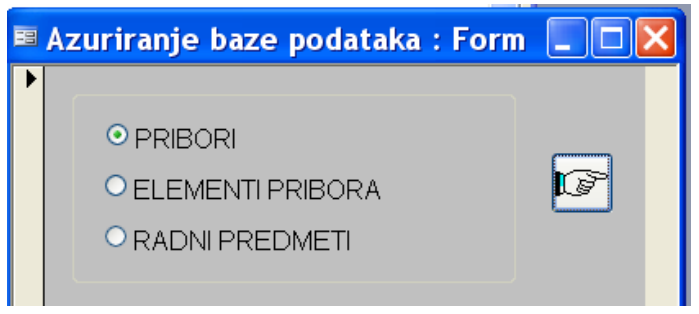

Slika 5.3. Izgled forme za izbor opcije ažuriranja

Brisanje odgovarajućih podataka podrazumeva uklanjanje podataka iz baze, tj. njoj pripadajuće datoteke, prvenstveno nakon isteka veka upotrebe 
nekog od elementa, kako se on ne bi koristio u procesu projektovanja i time izazvale određene zabune u toku samog procesa montaže pribora.

Menjanje podataka se vrši kad god dođe do neke promene (geometrijske, tehnološke i sl.) bilo elementa pribora, pribora ili pak radnog predmeta, a sve sa ciljem obezbeđivanja pouzdanog procesa projektovanja.

$U$ bazu podataka se unose informacije koje su vezane za konstrukcije pribora, elemente pribora i radne predmete, a unos ovih informacija vrši se u slučajevima:

- nabavke i/ili izrade novih dodatnih elementata pribora,

- završenog projektovanja pribora, kada je potrebno njegovo skladištenje u bazu podataka zajedno sa pridruženim radnim predmetom kako bi se isti mogao naknadno koristiti ako se za tim ukaže potreba.

Sam proces ažuriranja informacija vrši se putem formi (slika 5.4). Podaci se unose, menjaju ili brišu u za to predviđenim poljima i automatski ažuriraju u odgovarajućim tabelama u bazi podataka.

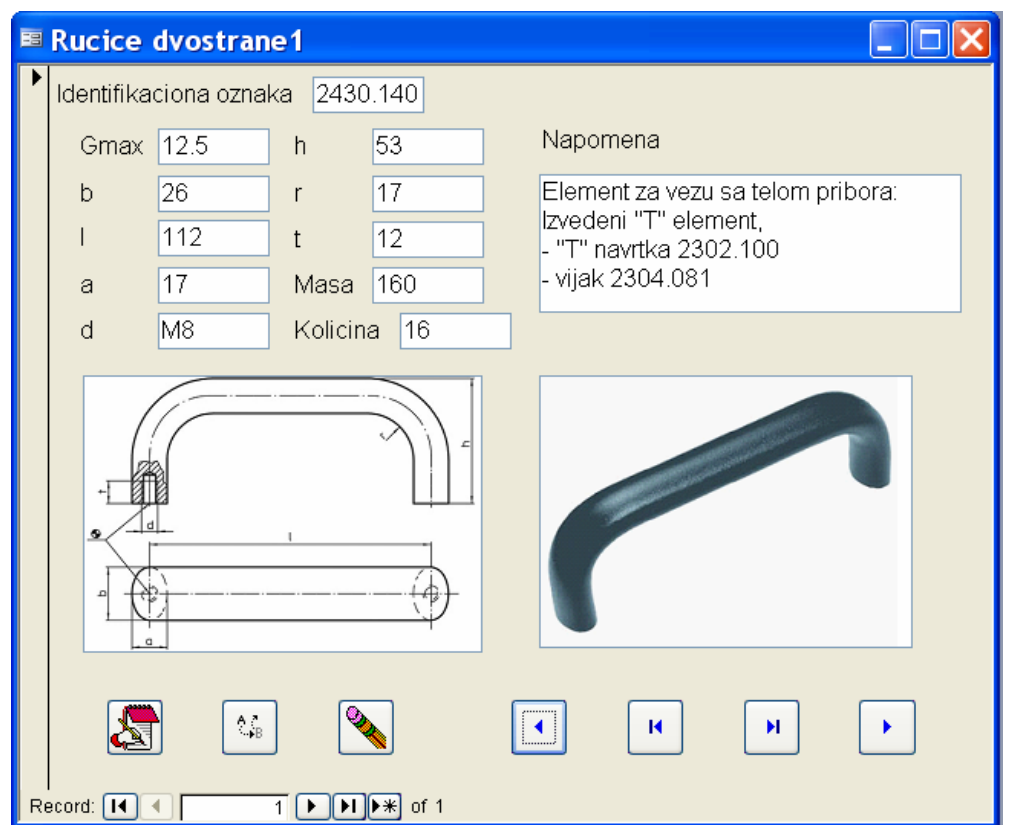

Slika 5.4. Izgled forme za ažuriranje podataka elemenata pribora

Tabele su tako organizovane da vrste predstavljaju različite varijante pribora, elemenata pribora, radnih predmeta i klasifikacionih obeležja, dok kolone predstavljaju odgovarajuće geometrijske, tehnološke i druge 
karakteristike svakog od njih ponaosob. Segment tabele je prikazan na slici 5.5 .

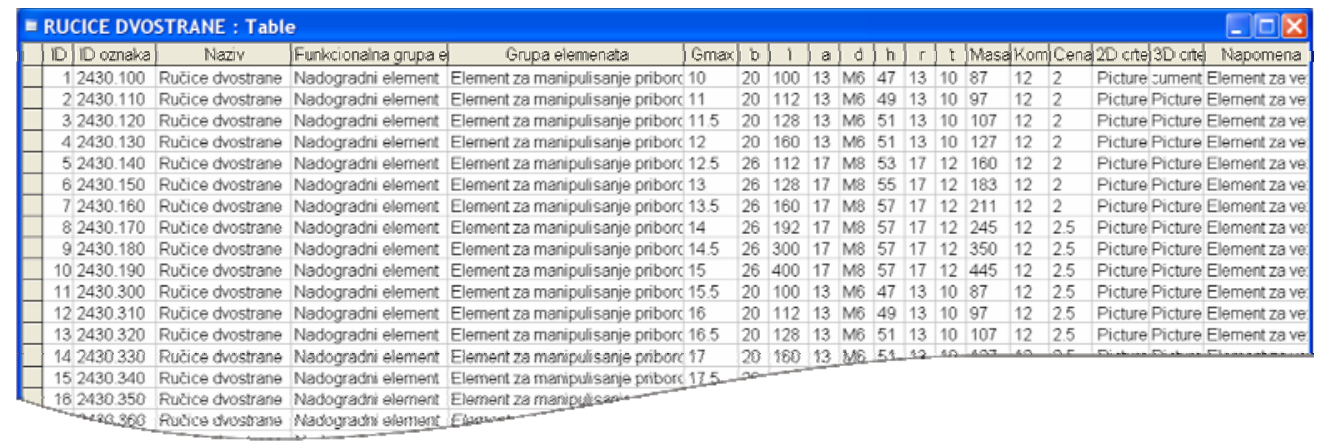

Slika 5.5. Segment tabele elemenata pribora u bazi podataka

Sa forme za unos, menjanje i brisanje podataka moguće je automatski generisati izveštaje u obliku karte pribora, karte radnog predmeta ili karte elementa pribora (slika 5.6).

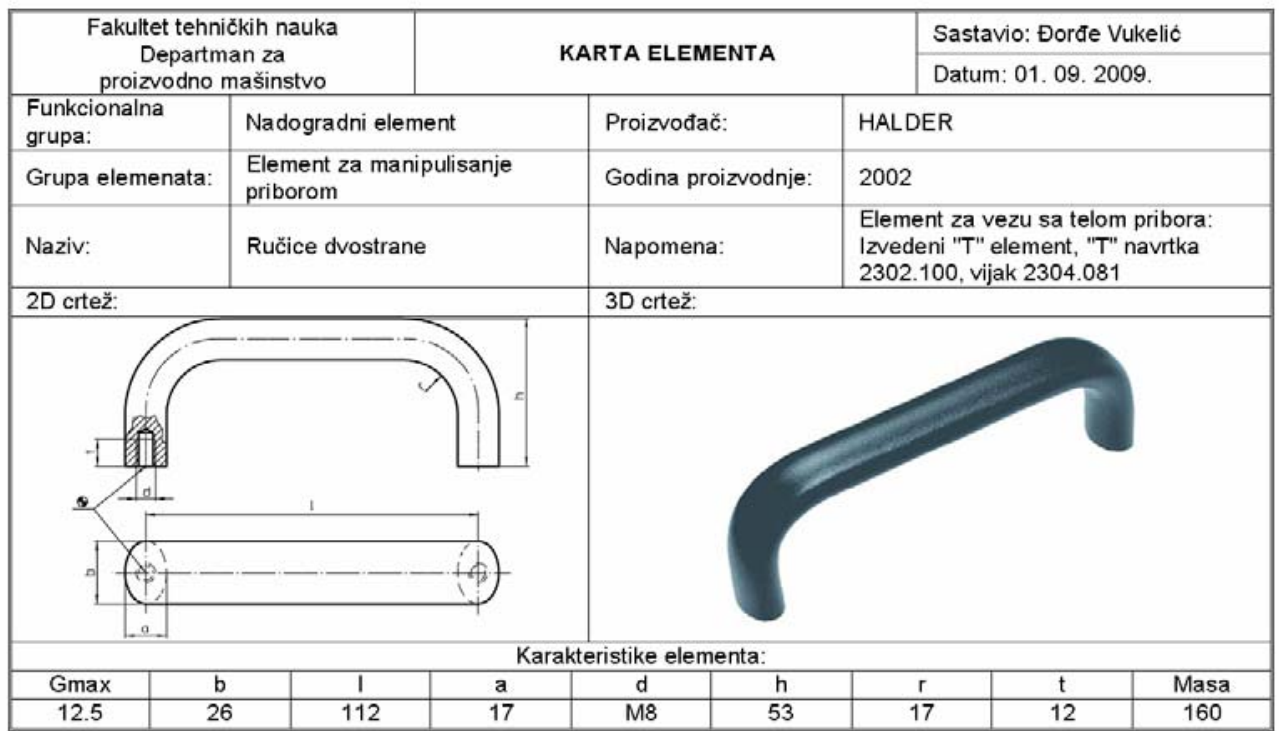

Slika 5.6. Karta elementa pribora

\subsubsection{Pretraživanje baze podataka}

Opciju pretraživanja baze podataka projektant koristi za dobijanje informacija o elementima i gotovim konstruktivnim rešenjima pribora. U zavisnosti od potreba projektant definiše kriterijume pretraživanja (slika 5.7). Moguće je zadati jedan ili više kriterijuma. 


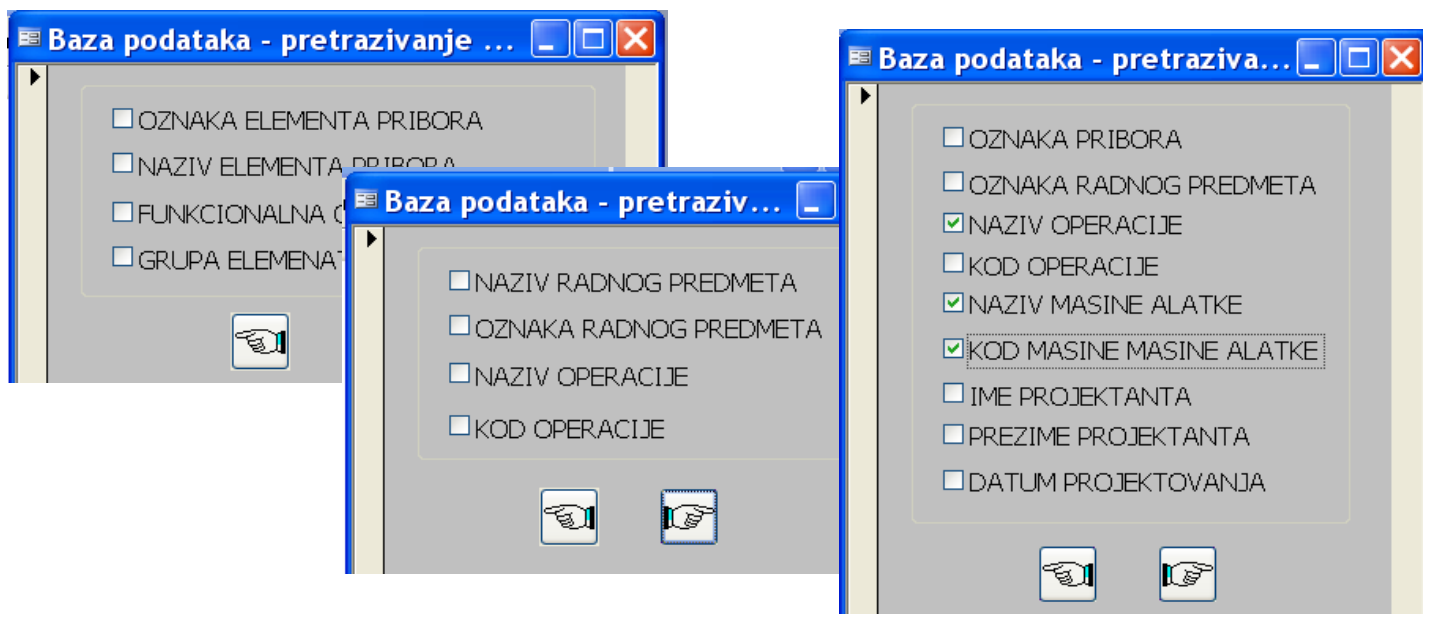

Slika 5.7. Forma za izbor opcija pretraživanja baze podataka

Na osnovu izabranih kriterijuma generiše se odgovarajuća forma (slika 5.8) u okviru koje se vrši izbor i/ili upis odgovarajućeg parametra (ili više njih) na osnovu kojeg će se vršiti pretraživanje. Po završetku izbora i/ili unosa parametara (po izabranim kriterijumima pretrage), projektantu je data mogućnost da definiše prioritet i redosled sortiranja podataka (slika 5.8).

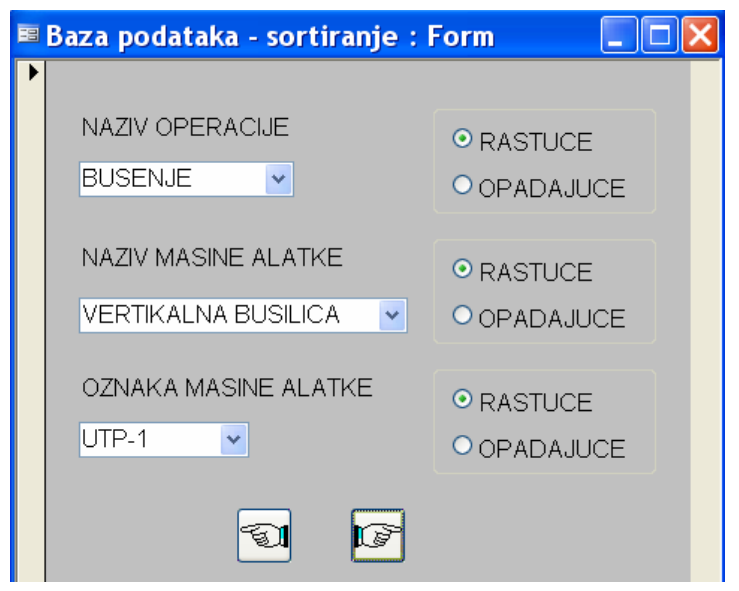

Slika 5.8. Pretraživanje baze podataka po konstruktivnim rešenjima pribora $i$ izbor načina sortiranja na osnovu izabranih kriterijuma pretrage

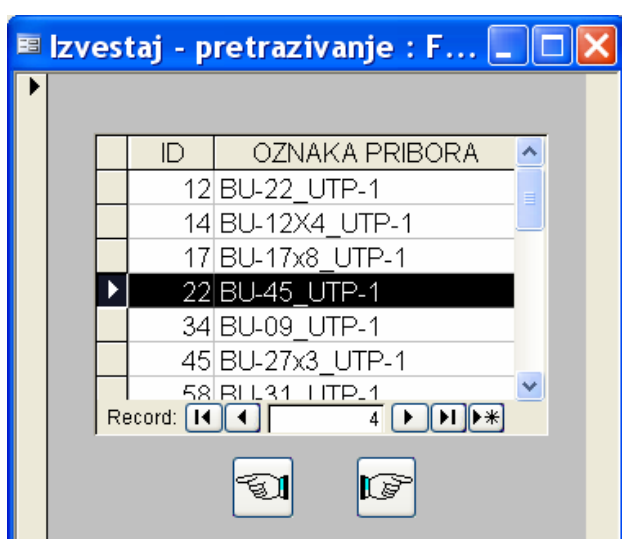

Slika 5.9. Primer generisanog izveštaja pretraživanja baze podataka

$\mathrm{Na}$ ovaj način, postavljanjem raznih upita pretrage i načina sortiranja potrebnih podataka, mogu se generisati različiti izveštaji pretraživanja baze podataka (slika 5.9). Pošto izabere odgovarajući rezultat pretraživanja, pred projektantom se otvara forma za prikaz pribora (slika 5.10). Svi podaci se automatski preuzimaju iz datoteke gotovih konstruktivnih rešenja pribora. 


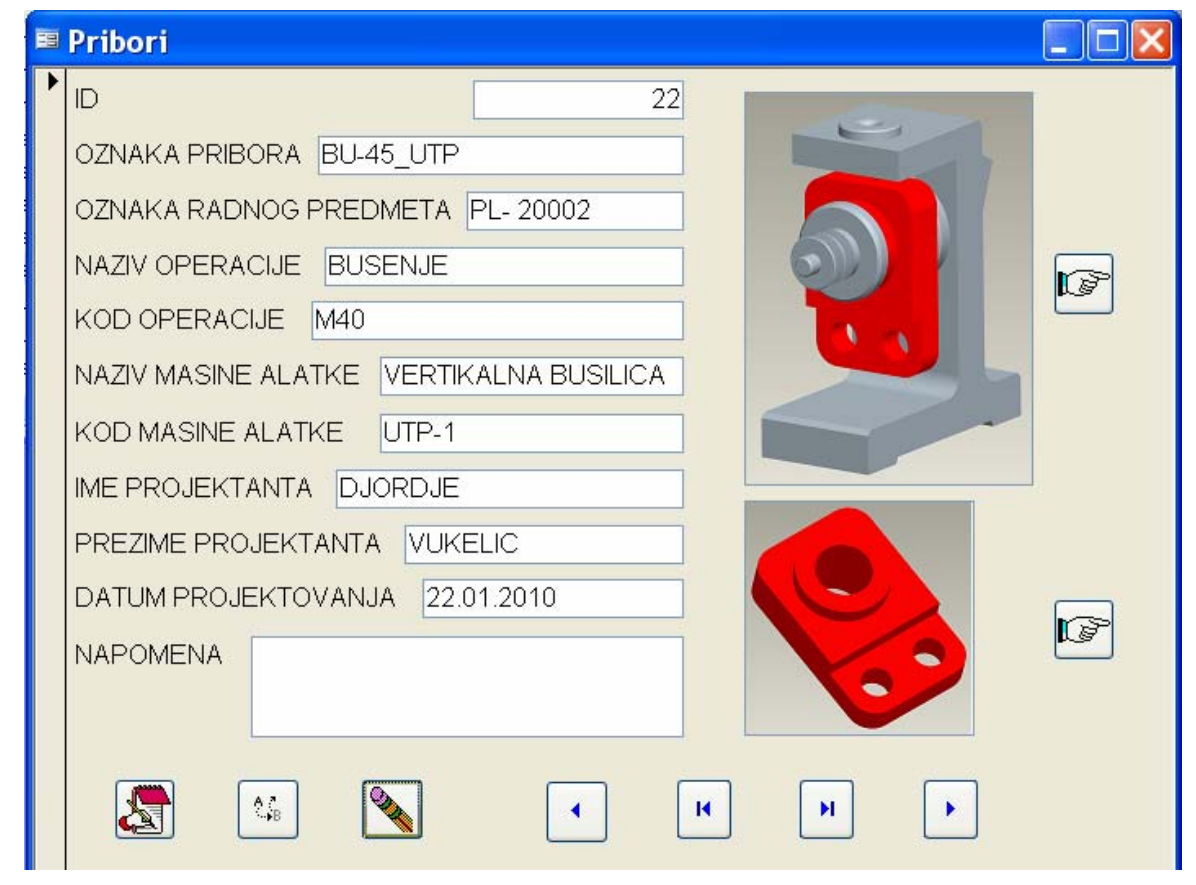

Slika 5.10. Izgled forme za prikaz pribora

\subsubsection{Rešenje baze znanja}

Produkcioni sistemi su programi koji koriste proces zaključivanja (rezonovanja) nalik ljudskom zaključivanju kod rešavanja problema iz raznovrsnih domena. Ovo zaključivanje zasniva se na ekpertskom ljudskom znanju koje je kodirano u programu u vidu posebne strukture koja se naziva baza znanja. Poseban mehanizam koristi raspoloživo znanje u procesu zaključivanja kako bi se došlo do rešenja. Na taj način rešavaju se problemi koji su izvan domašaja konvencionalnih računarskih programa. Funkcionisanje ovih sistema zasniva se na simboličkom predstavljanju i procesiranju ugrađenog znanja. Znanje se predstavlja preko formalnih simbola i pogodnih struktura podataka iskazanih u nekom programskom jeziku, a problemi se rešavaju izvođenjem induktivnih i deduktivnih zaključaka putem manipulacije tim simbolima i strukturama.

Pri razvoju baze znanja mogu se identifikovati sledeće faze:

- Faza procene

Tokom ove faze se identifikuju problemi, izvodivost njihovog rešenja $u$ odnosu na ciljeve i drugi važni činioci kao što su ciljevi, oblast i potrebni resursi - podaci i ljudi (eksperti).

- Faza prikupljanja znanja 
Znanje se preuzima od eksperata, organizuje i proučava kako radi boljeg uvida u problem, tako i za potrebe daljeg razvoja. $U$ fazi prikupljanja znanja iz procesa projektovanja pribora vrši se akvizicija činjeničnog i heurističkog znanja. Potom se ovo znanje kodira i unosi u sistem. Tokom rada znanje se ne može menjati, ali je to moguće učiniti pre ili nakon korišćenja istog.

- Faza projektovanja

Definišu se struktura i organizacija znanja sistema, metodi obrade znanja - bira se alat kojim se znanje predstavlja i obrađuje (način zaključivanja i upravljanja znanjem).

- Faza testiranja

Ova faza se često odvija tokom svih prethodnih faza, i nakon nje se po potrebi iterativno vraća na neku od prethodnih.

- Faza dokumentacije

Specifičnost u odnosu na konvencionalnu dokumentaciju je rečnik znanja - daje inženjeru uvid u organizovano predstavljeno znanje $i$ procedure rešavanja sistema.

- Faza održavanja

Produkcioni sistem je, po pravilu, sistem koji živi, jer se baza znanja menja s vremenom.

Takođe, tokom razvoja baze znanja vodilo se računa o:

- Mogućnosti proširivanja

Programi i strukture podataka trebalo bi da budu fleksibilni kako bi se proširivanje baze znanja vršilo bez velikih korekcija ili uz minimalne korekcije programskog koda.

- Jednostavnosti

Predstavljanje znanja treba da bude jednostavno. Jednostavnost koncepta može da se ostvari ako se znanje izražava na što homogeniji način.

- Eksplicitnosti

Znanje treba da bude predstavljeno eksplicitno. Ovo je važno u otkrivanju grešaka i davanju objašnjenja u radu sistema. 
Za razliku od podataka o priborima i elementima pribora smeštenim u bazi podataka, koji su pasivni, za znanje smešteno u bazi znanja kažemo da je aktivno. Svrha predstavljanja znanja je da se ono organizuje u takvoj formi da program može direktno da ga koristi u procesu odlučivanja, prepoznavanju elemenata, izvođenju zaključaka itd. Stoga je predstavljanje znanja ključno pitanje. Šeme za predstavljanje znanja se dele na deklarativne i proceduralne. Deklarativni pristup podrazumeva predstavljanje znanja u obliku nezavisnih modularnih celina, iskaza, činjenica i struktura podataka. Ovi elementi znanja su pasivni, što znači da ne predstavljaju programske celine koje u sebi sadrže eksplicitan niz programskih komandi i redosled izvršavanja tih komandi. Jedini program koji koristi te elemente pri rešavanju problema je mehanizam zaključivanja. Osnovna prednost deklarativnog pristupa u predstavljanju znanja je modularnost znanja. Izmene u bazi znanja i njena nadgradnja su zahvaljujući tome olakšane. Proceduralni pristup se odnosi na direktno unošenje znanja u programske procedure u vidu eksplicitnog programskog koda. Mehanizam zaključivanja pri radu poziva te procedure i tako koristi u njih ugrađeno znanje.

Baza znanja je specijalizovana i sadrži znanje eksperta iz oblasti projektovanja pribora. Znanje se unosi u sistem kroz sistem prikupljanja znanja i ne menja se tokom rada sistema. Ti podaci su promenljivi i svojim vrednostima odražavaju trenutno stanje u procesu izbora elemenata pribora. Mehanizam zaključivanja je program koji na osnovu tih promenljivih podataka i znanja ugrađenog u bazu znanja rešava problem, odnosno obavlja zadatak. Preko interfejsa prema korisniku odvijaju se komunikacija između sistema i korisnika i prezentacija rezultata. Sistem izvodi zaključke na osnovu kodiranog znanja iz domena projektovanja pribora, tj. iz domena izbora elemenata pribora na osnovu funkcionalnih, geometrijskih i tehnoloških ograničenja unetih u okviru modula za ulazne informacije i generisanih u okviru modula za optimizaciju konstrukcije pribora.

Kako bi produkcioni sistemi, kao i drugi sistemi veštačke inteligencije koji su zasnovani na znanju, mogli ispravno da funkcionišu, treba da obezbede mogućnost ažuriranja znanja i postupke za efikasnu manipulaciju njima.

Sistem je tako organizovan da se bazi znanja pristupa preko odgovarajuće forme (slika 5.11.). Na ovaj način se direktno pristupa bazi znanja za određenu funkcionalnu grupu elemenata pribora.

Osnovne komponente ovog dela sistema su (slika 5.12):

- pitanja koja se postavljaju korisniku,

- pravila koja se proveravaju - da li je ispunjen uslov za određenu akciju, 
- izbori - akcije koje se preduzimaju ako je ispunjen određeni uslov.

$\mathrm{Na}$ osnovu pitanja koja se postavljaju projektantu, karakterističnih za svaku grupu elemenata pribora, i izabranih opcija, generišu se odgovarajuća produkciona pravila za izbor konkretnih elemenata pribora i smeštaju u bazu znanja (slika 5.13).

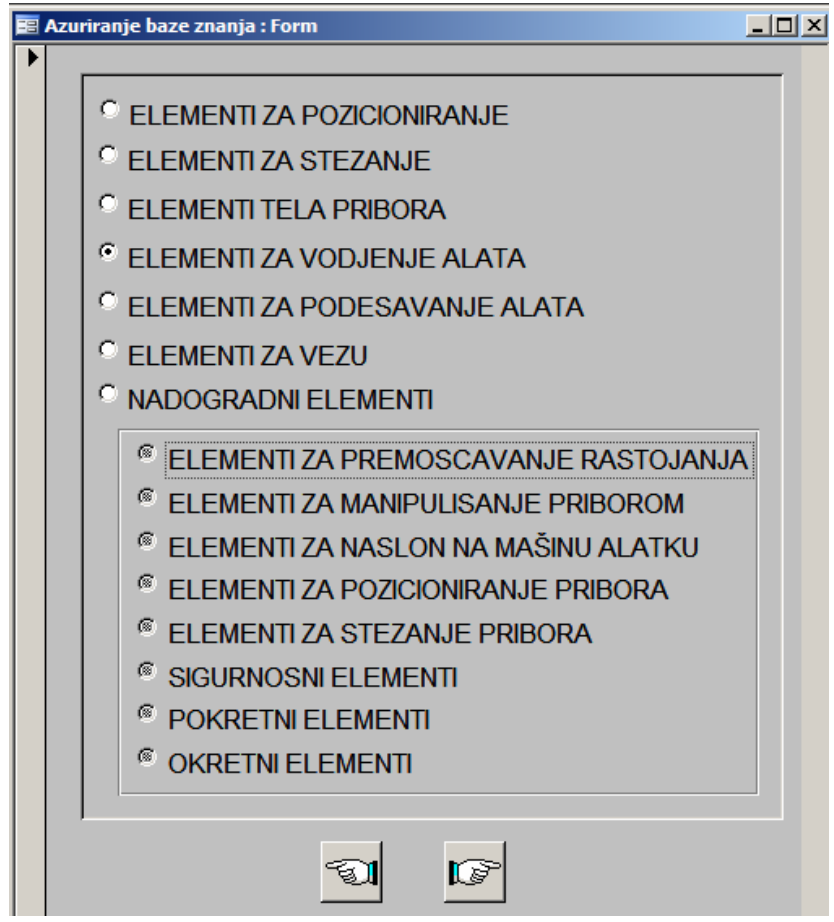

Slika 5.11. Forma za izbor funkcionalne grupe elemenata za koje se vrši ažuriranje baze znanja

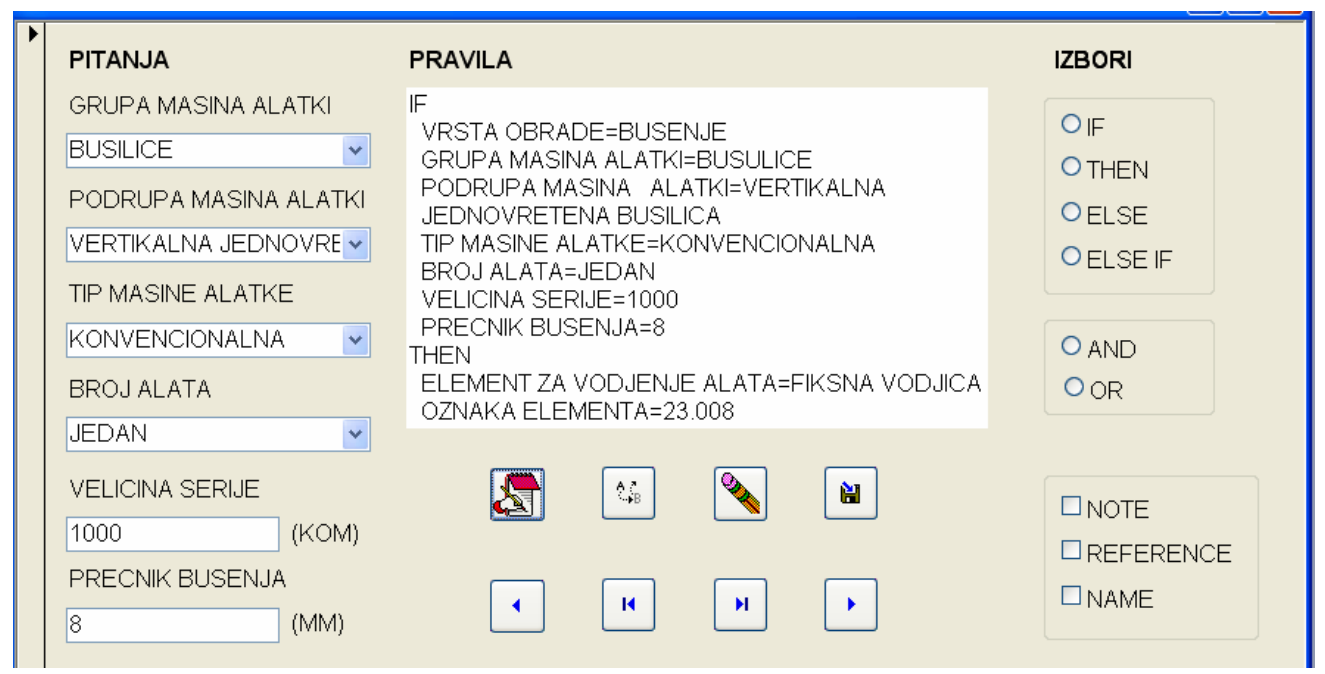

Slika 5.12. Forma za prikaz produkcionih pravila u bazi znanja 
$\mathrm{Na}$ ovoj formi (slika 5.12) je moguće vršiti i korekcije i brisanje postojećih produkcionih pravila. Obezbeđeno je i detektovanje suprotstavljenih znanja kada se novo znanje dodaje u bazu znanja. Nakon unosa novog produkcionog pravila u bazu znanja ili modifikovanja postojećeg, obezbeđeno je automatsko detektovanje pribora za koji je to pravilo upotrebljeno u procesu projektovanja. U tom slučaju projektant pribora mora da odluči da li je novo pravilo moguće primeniti na postojeću (prethodno projektovanu) konstrukciju ili više njih i da u skladu sa tim izvrši odgovarajuće korekcije ili da ne primeni novo pravilo i da u bazi podataka zadrži postojeće uz novododato. U ovom slučaju sistem uvek generiše najmanje dva elementa kojima se može ostvariti ista funkcija u kasnijim fazama projektovanja.

\subsubsection{Rešenja modula sistema}

Izborom opcije za projektovanje pribora (slika 5.1) započinje proces projektovanja nove konstrukcije pribora. Proces projektovanja se obavlja u nekoliko faza u sklopu pojedinih modula sistema čije je funkcionisanje opisano u nastavku.

\subsubsection{Modul za unos ulaznih informacija}

U okviru modula za ulazne informacije vrši se kodiranje svih potrebnih informacija za pravilnu optimizaciju i projektovanje nove konstrukcije pribora. Kodiranje ulaznih informacija (slike 5.13 i 5.14) projektant izvodi putem formi, tj. pojedinih segmenata formi u koje unosi potrebne podatke ili vrši izbor istih.

Nakon što se izvrši unos svih potrebnih informacija (obeležja) u okviru svakog bloka, prelazi se u modul za definisanje koncepcije pribora. 


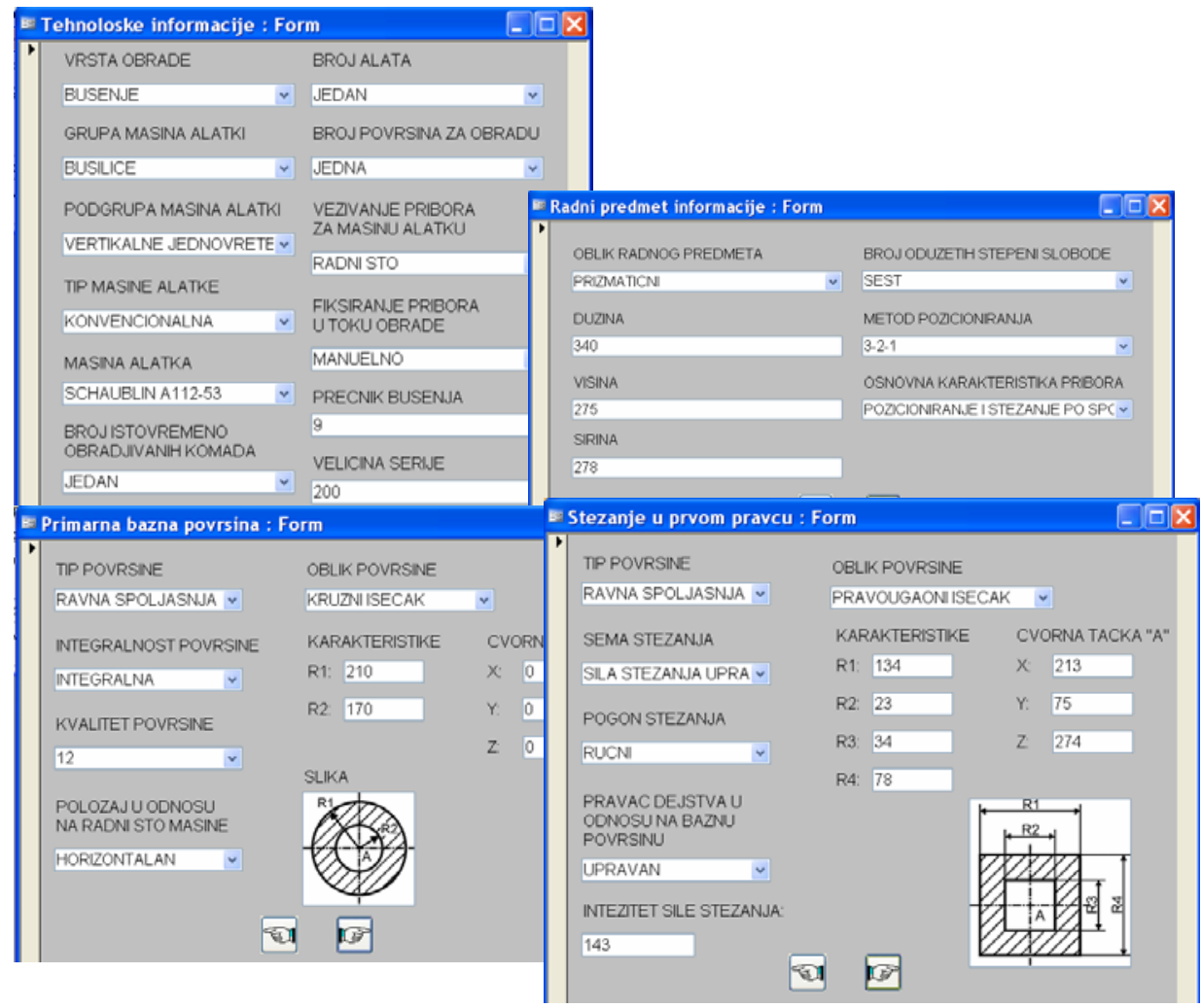

Slika 5.13. Segment formi za kodiranje ulaznih informacija

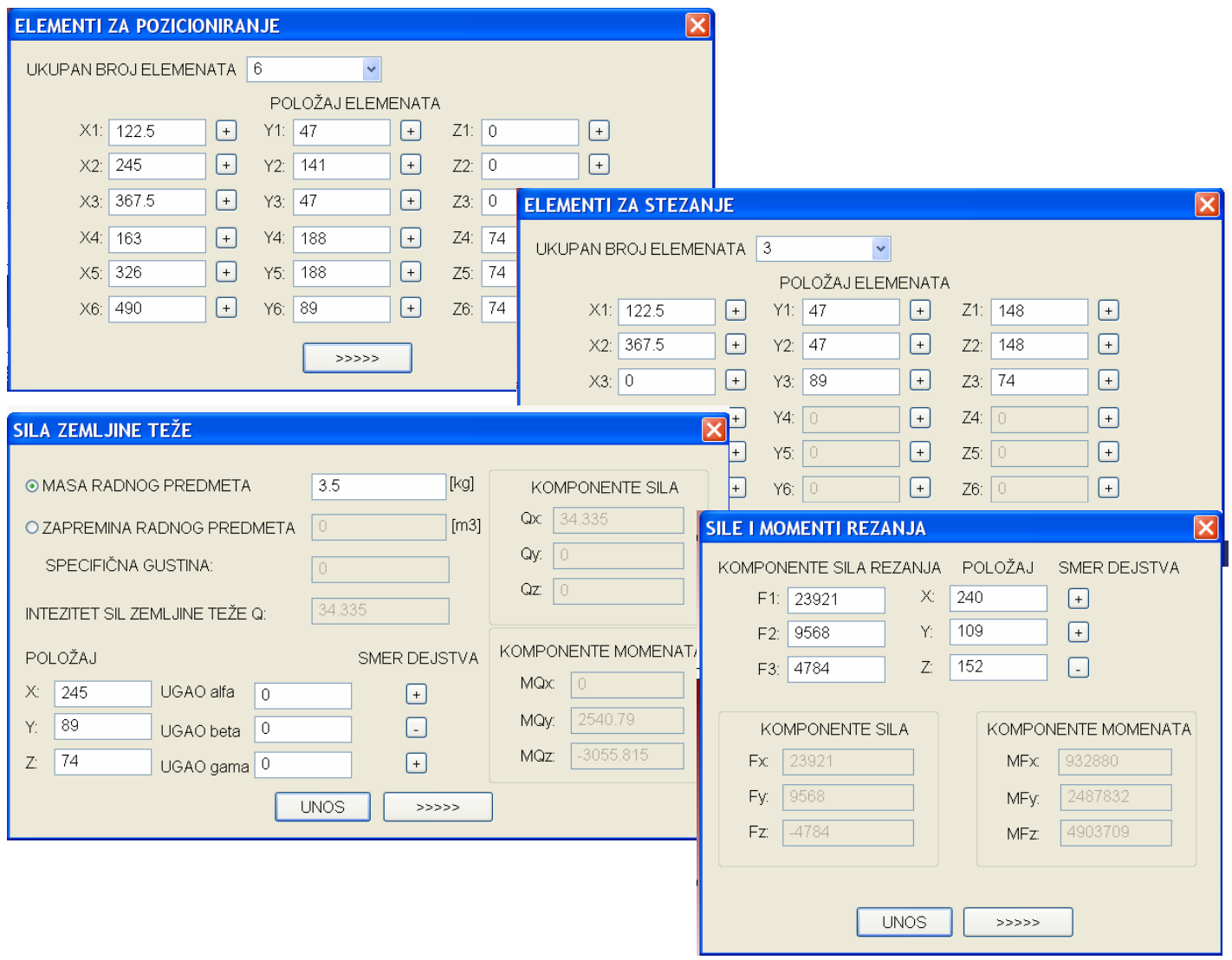

Slika 5.14. Forme za unos sila i momenata 


\subsubsection{Modul za planiranje koncepcije pribora}

U okviru modula za planiranje i optimizaciju konstrukcije pribora definišu se optimalne pozicije elemenata za pozicioniranje i stezanje.

Prvi korak koji se sprovodi u okviru ovog modula jeste definisanje mogućih površina za pozicioniranje. Za izabrane karakteristične šeme pozicioniranja i vrstu obrade koja se izvodi na radnom predmetu vrši se automatizovani proračun dozvoljenih grešaka pozicioniranja. Na slikama 5.155.17 prikazane su karakteristične forme za determinisanje mogućih šema pozicioniranja:

- slučaj provere greške pozicioniranja pri pozicioniranju radnog predmeta na ravnu površinu,

- slučaj provere greške pozicioniranja pri pozicioniranju radnog predmeta preko otvora,

- slučaj provere greške pozicioniranja pri pozicioniranju radnog predmeta preko spoljašnje cilindrične površine upotrebom prizme.

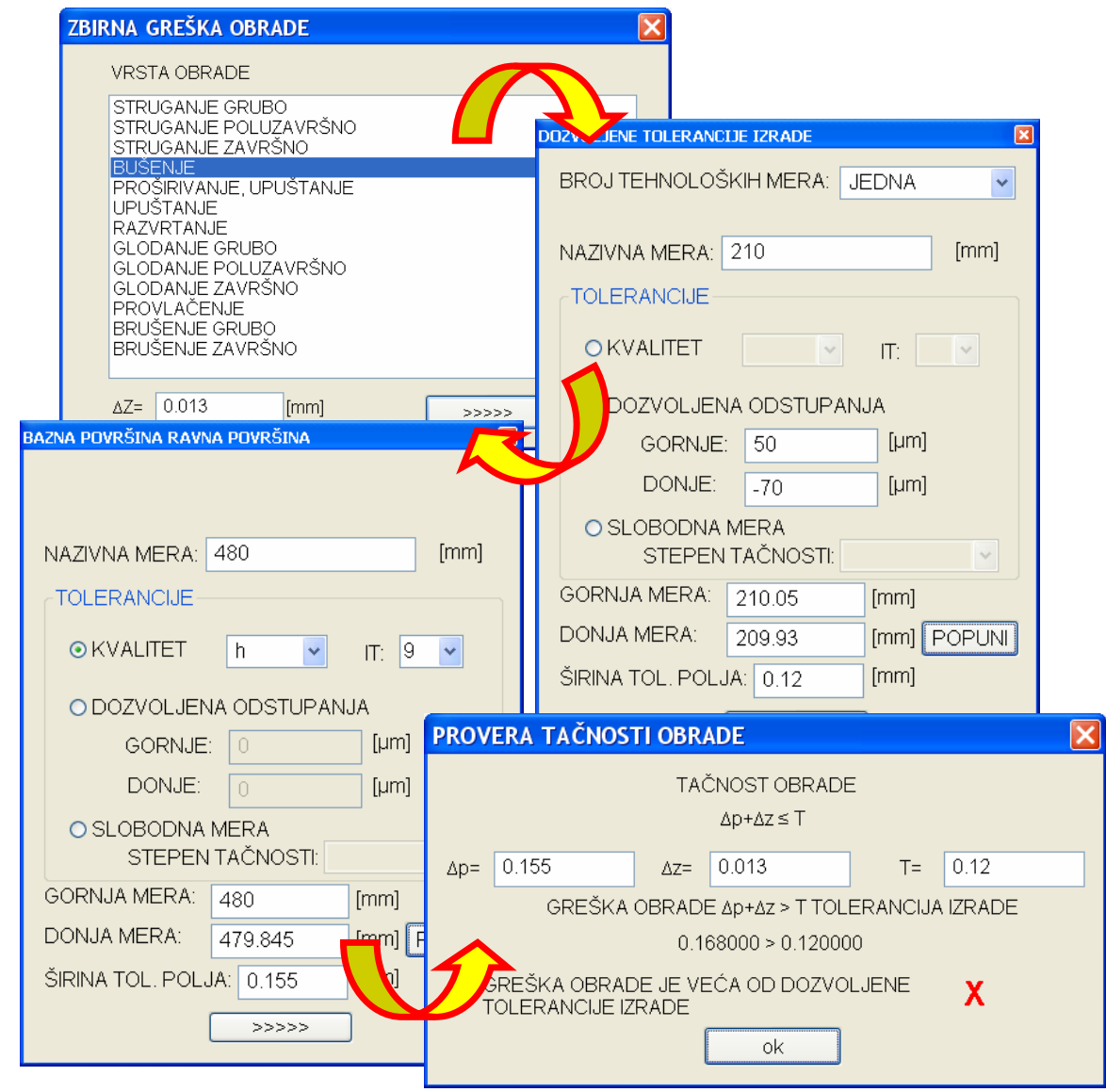

Slika 5.15. Provera tačnosti obrade (bazna površina - ravna površina) 


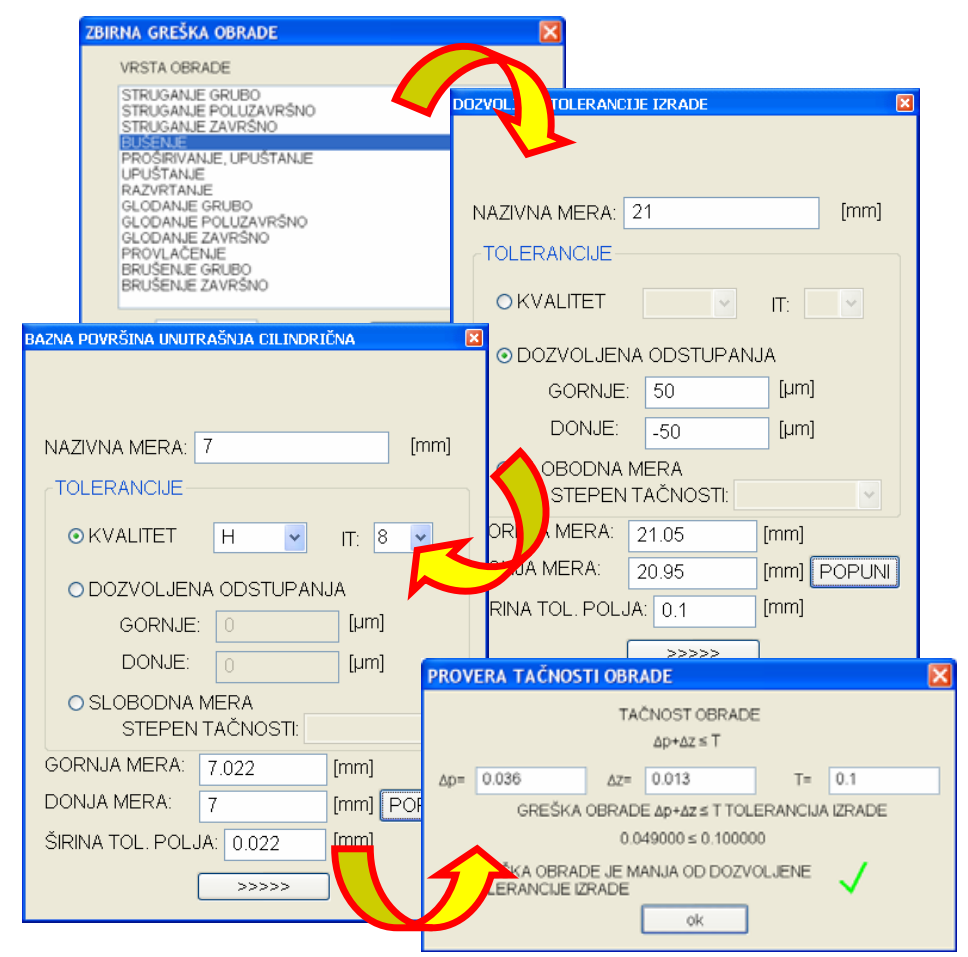

Slika 5.16. Provera tačnosti obrade (bazna površina - otvor)

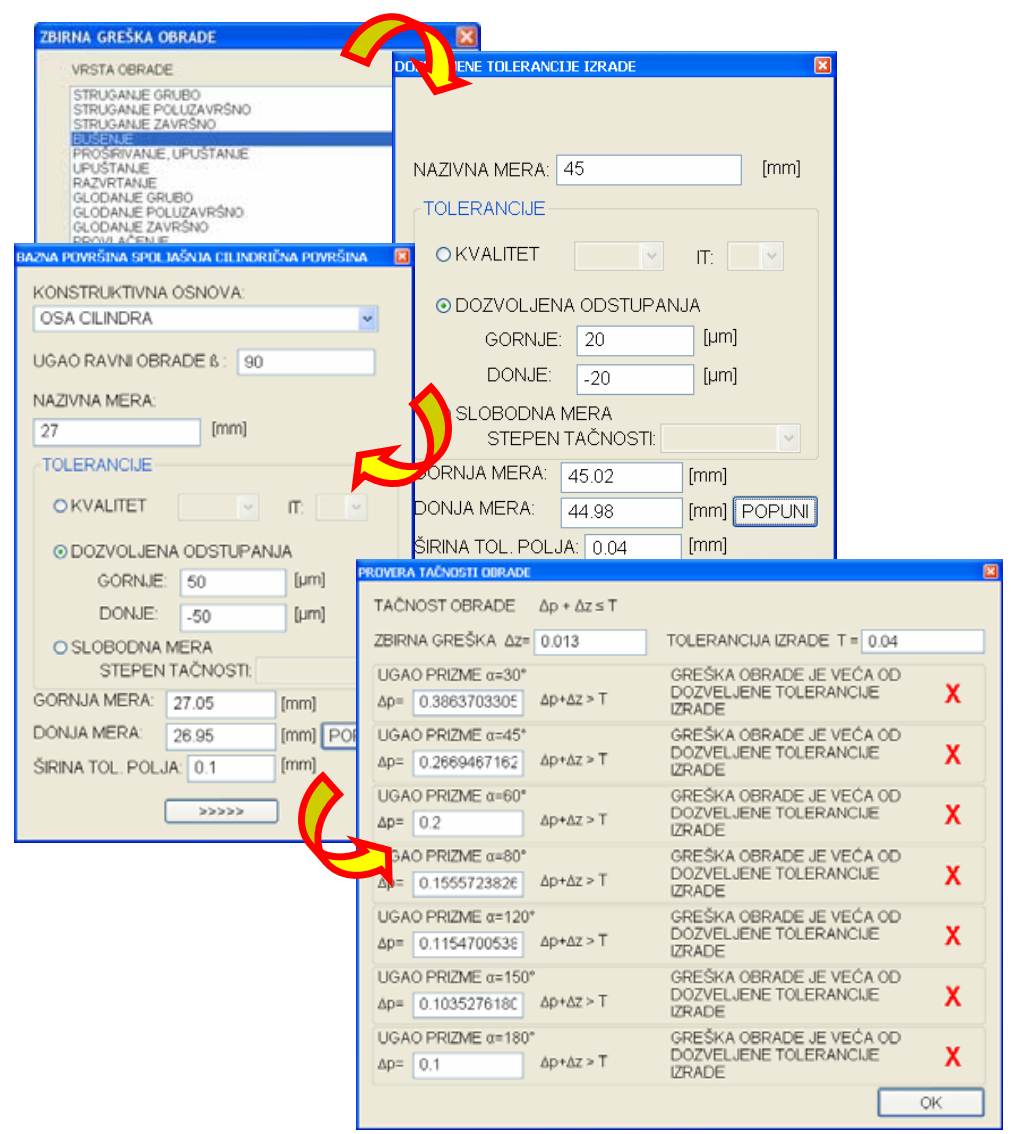

Slika 5.17. Provera tačnosti obrade (bazna površina - spoljašnja cilindrična površina) 
$\mathrm{Na}$ osnovu proračunatih grešaka pozicioniranja selektuju se površine preko kojih je moguće pozicionirati radni predmet, a na osnovu njih i površine preko kojih je moguće izvesti stezanje radnog predmeta. Definišu se odgovarajuće površine prema svojoj geometriji, definiše se čvorna tačka svakog geometrijskog oblika (privremenim vraćanjem u modul za ulazne informacije) i zadaju se inicijalne pozicije elemenata za pozicioniranje i stezanje.

Potom se sprovodi procedura optimizacije konstrukcije pribora. Proceduru optimizacije šema pozicioniranja i stezanja sprovodi genetski algoritam na osnovu unetih pozicija i intenziteta sila koje se javljaju u toku procesa obrade.

Kada se rešava problem uz pomoć genetskog algoritma, potrebno ga je prilagoditi genetskom algoritmu. Moguće rešenje se prikazuje kao niz bita (binarni prikaz). Svaka jedinka predstavlja potencijalno rešenje i svaka jedinka je predstavljena strukturom u vidu niza gena.

Prilikom inicijalizacije generiše se početna populacija jedinki. Inicijalizacija se vrši izborom $n$ jedinki na slučajan način. Ovaj skup jedinki tj. skup rešenja čine nepoznate sile stezanja i njihove pozicije, kao i nepoznate reakcije oslonaca i njihove pozicije. Svaka jedinka predstavlja jedno potencijalno rešenje. Fitness funkcija (funkcija dobrote, funkcija cilja) je evoluciona funkcija koja određuje da li je neko rešenje bolje od drugih. Ona se računa za svaku jedinku. Za svaku jedniku je funkcija cilja minimizacija sile uz odgovarajuća ograničenja. Inicijalno (početno) rešenje je rešenje odabrano iz domena mogućih, na način kako je to ranije prikazano (poglavlje 4.2.1.2.).

U okviru selekcije dolazi do „preživljavanja“ dobrih i „odumiranja“ Ioših jedinki. Dobre jedinke imaju manji intenzitet sile, a loše veći intezitet sile u odnosu na početno inicijalno rešenje. Selekcija se vrši na osnovu "eliminacijskog turnirskog izbora". Na slučajan način se odabere $n$ jedinki. Najlošija među jedinkama (najveći intenzitet sile) se eliminiše i zamenjuje novom jedinkom upotrebom genetskih operatora ukrštanja i mutacije. Selekcija je u stvari izdvajanje najsposobnijih jedinki unutar svake generacije.

Ukrštanje je genetski koncept reprodukcije pri kojem se kombinuje genetski materijal dva roditelja sa ciljem dobijanja superirornijeg naslednika. Stvaraju se nove jedinke nakon eliminacije postojećih. Pri ukrštanju se izabere slučajan broj i ako je on manji od verovatnoće ukrštanja $p_{c}(0.5)$ vrši se ukrštanje. To znači da ukrštanju podleže $p_{c}{ }^{*} \mathrm{k}$ hromozoma.

Mutacija se vrši na malom delu populacije da ne bi došlo do nestabilnosti procedure. Mutacijom se obnavlja izgubljeni genetski materijal i 
izbegavaju lokalni minimumi sila. Pri mutaciji se izabere slučajan broj i ako je on manji od verovatnoće mutacije $p_{m}(0.005)$ vrši se izmena gena. To znači da mutaciji podleže $p_{m}{ }^{*} k^{*} m$ gena.

Jedan od najvažnijih parametara je kriterijum zaustavljanja. Kao kriterijum zaustavljanja može se izabrati: broj iteracija (generacija), dostignuta vrednost funkcije cilja, broj iteracija bez poboljšanja i vremensko ograničenje (slika 5.18).

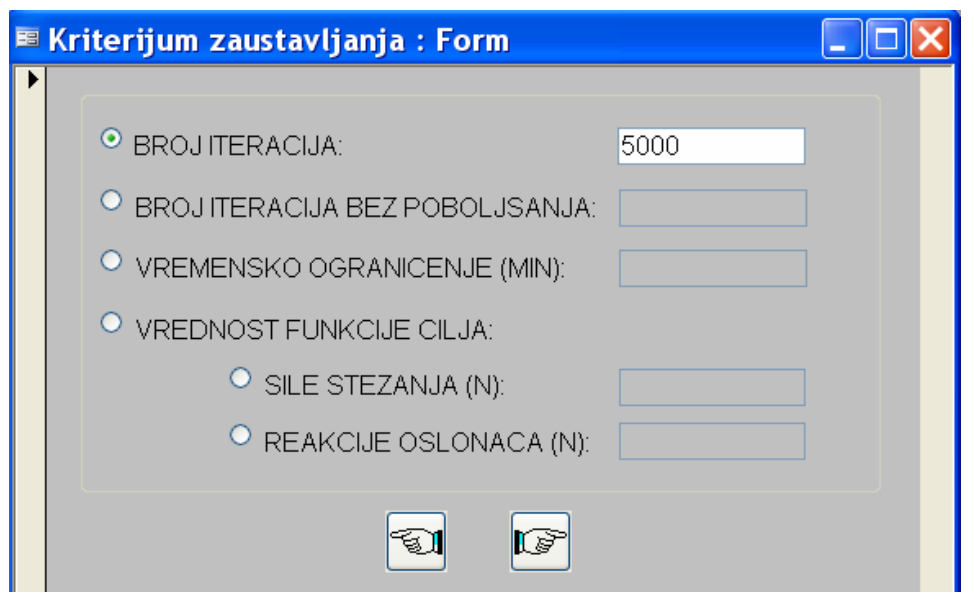

Slika 5.18. Izbor kriterijuma zaustavljanja genetskog algoritma

Nakon određenog broja izvršenih iteracija (generacija), kada se uslov zaustavljanja zadovolji, postupak optimizacije se zaustavlja, a najbolji članovi trenutne populacije predstavljaju rešenja koja bi trebalo da budu optimalna (slika 5.19).

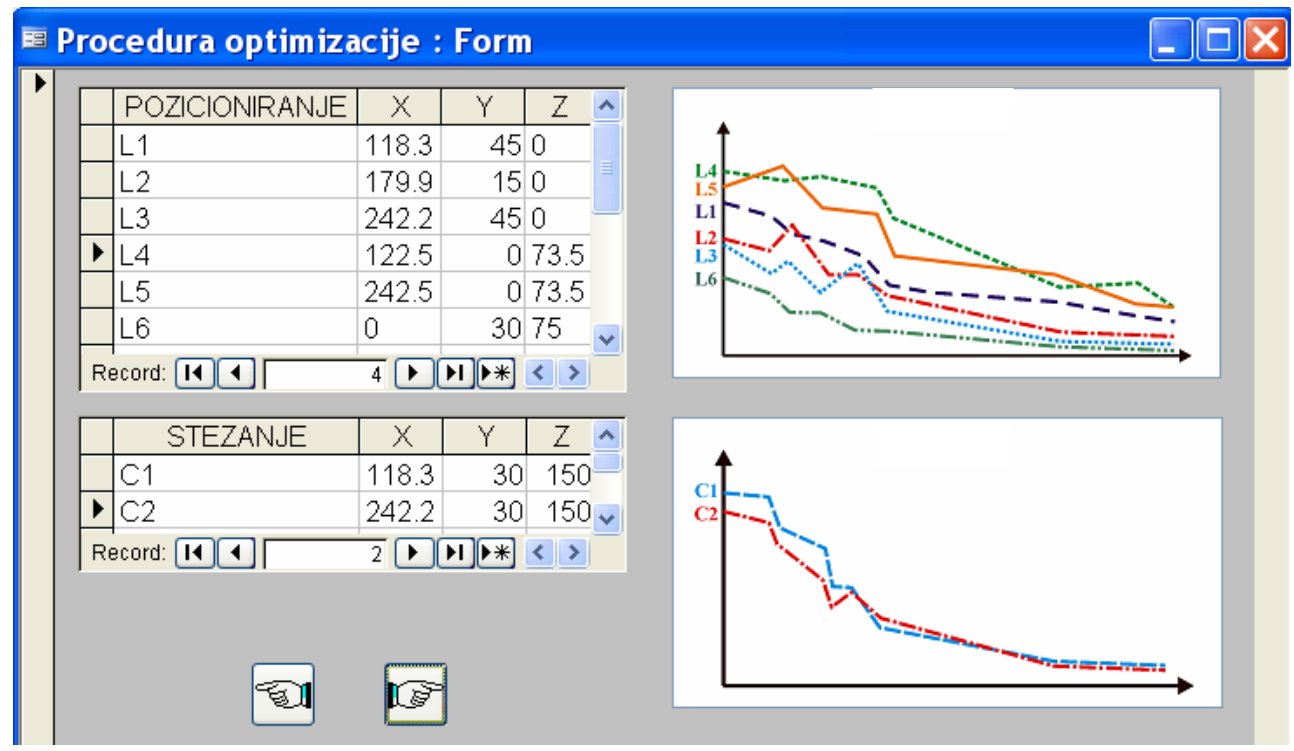

Slika 5.19. Optimalne pozicije elemenata za pozicioniranje i stezanje 


\subsubsection{Modul za sintezu pribora}

Izbor svakog elementa pribora iz baze podataka elemenata pribora obavlja se po produkcionim pravilima prethodno definisanim u bazi znanja. Ulazne informacije su kodirane u okviru modula za ulazne informacije. Pojedina obeležja kodova sadrže tačno određenu strategiju izbora pojedinih elemenata. Mehanizam zaključivanja selektuje određeno znanje iz baze znanja na osnovu kojeg se selektuju odgovarajući elementi pribora. Pretražuje se baza znanja kako bi se pronašla ona pravila čijim klauzulama odgovaraju podaci u radnoj memoriji. Ovo pretraživanje se vrši „strategijom ulančavanja unapred“. Ulančavanje unapred polazi od premisa, "If“ delova pravila, i upoređuje in sa podacima u memoriji računara. Time se utvrđuje koja su pravila zadovoljena - to su ona čija je premisa nađena među podacima $u$ memoriji. Pravila koja su zadovoljena mogu se realizovati tako da se njihovi „Then“ delovi izvrše (prikaz istinitih iskaza). Izvršavanje neke akcije menja stanje podataka u memoriji; iskaz koji je istinit dodaje se već postojećim podacima u memoriji. Tako se dobija novo stanje podataka u memoriji računara. Proverava se da li je moguće rešiti problem, a ukoliko jeste projektant se obaveštava o tome i dobija listing elemenata pribora koje je moguće upotrebiti za generisanje nove konstrukcije pribora.

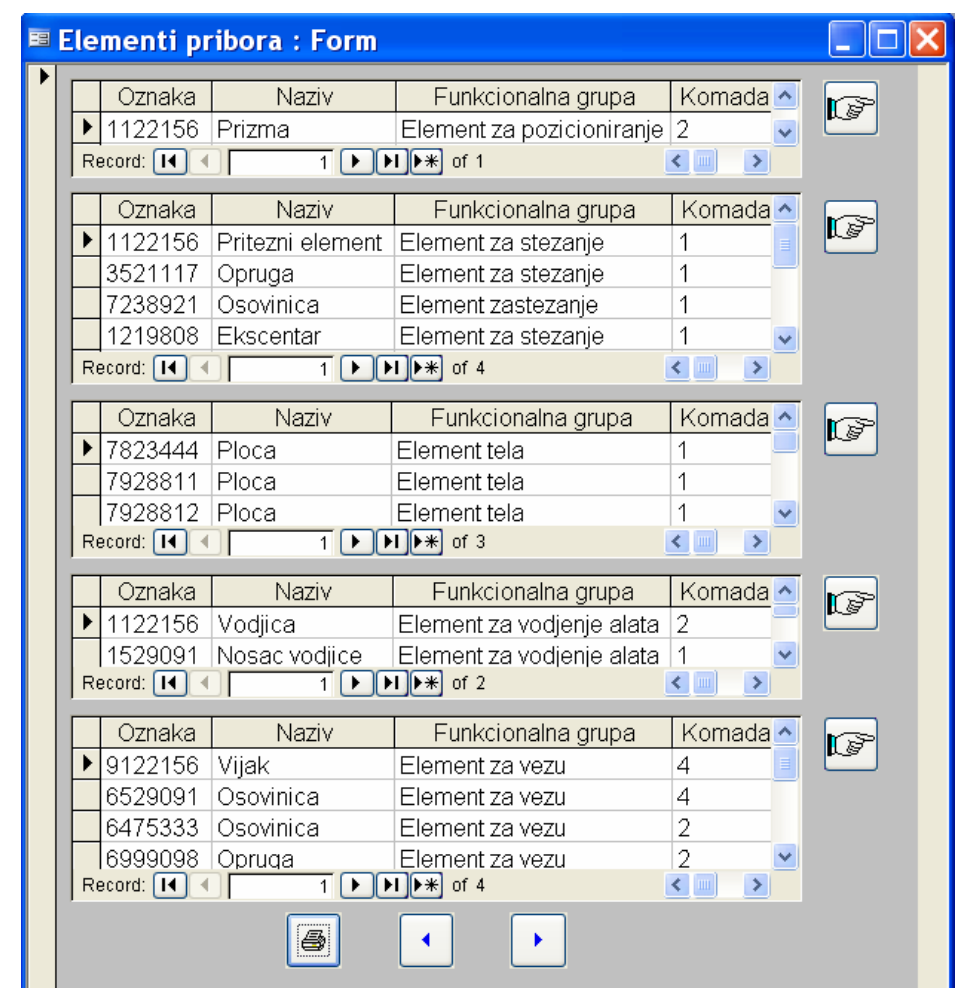

Slika 5.20. Forma sa prikazom mogućih elemenata pribora po funkcionalnim grupama pripadnosti elemenata 
Lista elemenata (slika 5.20) se fomira na osnovu ulaznih informacija generisanih u okviru modula za ulazne informacije, produkcionih pravila izbora svakog elementa iz pojedinih funkcionalnih grupa i informacija dobijenih $u$ modulu za optimizaciju konstrukcije pribora (šeme pozicioniranja i šeme stezanja). Ukoliko neko rešenje nije nađeno, postupak se iterativno ponavlja za tu funkcionalnu grupu elemenata pribora. Ako se prilikom pretraživanja pravila u bazi znanja pokaže da nijedno pravilo nije zadovoljeno, sistem zaključuje da nema dovoljno podataka da bi problem mogao da se reši. Tada može ili da prekine sa radom, ili da od korisnika zahteva dodatne informacije. Moguće je dobiti veći broj elemenata koji zadovoljavaju postavljene kriterijume, a obavljaju istu funkciju. Ukoliko dođe do slučaja da je zadovoljeno više pravila, strategija pretraživanja nalaže projektantu da odabere jedno od više mogućih rešenja koje će primeniti.

Pošto projektant u ovom trenutku projektovanja ima izabrane elemente pribora, u sledećem koraku se prelazi u modul za izlazne informacije kako bi se izvršilo komponovanje modularnog pribora.

\subsubsection{Modul za izlazne informacije}

Modul za izlazne informacije predstavlja poslednji segment sistema za automatizovano projektovanje i optimizaciju konstrukcije pribora. Osnovni zadatak ovog modula jeste da obezbedi sastavljanje nove konstrukcije pribora.

Prilikom projektovanja nove konstrukcije potrebnog pribora vrši se izbor i unos potrebnih elemenata. Oni se biraju sa odgovarajućih formi generisanih u okviru modula za sintezu pribora. Potrebni elementi se u sklop unose postepeno, jedan po jedan, radi bolje preglednosti i izbegavanja mogućih kolizija. Prvo se unosi radni predmet, potom elementi za pozicioniranje, pa elementi za stezanje itd., već prema konkretnim potrebama. Svaki element je pogodno, odmah nakon unosa, rasporediti oko modela radnog predmeta na određeno mesto, koristeći određena ograničenja (upravnost, simetričnost, tangentnost, paralelnost, itd.), kao i osnovne funkcije manipulacijom nad objektima - translaciju i rotiranje. Moguće je i formiranje jednog ili više podsklopova i njihovog zajedničkog unošenja. Elemeti za pozicioniranje i stezanje se unose na tačno određena mesta definisana u okviru modula za planiranje koncepcije pribora.

Primer postepene sinteze pribora u nekoliko koraka prikazan je na slici 5.21. 


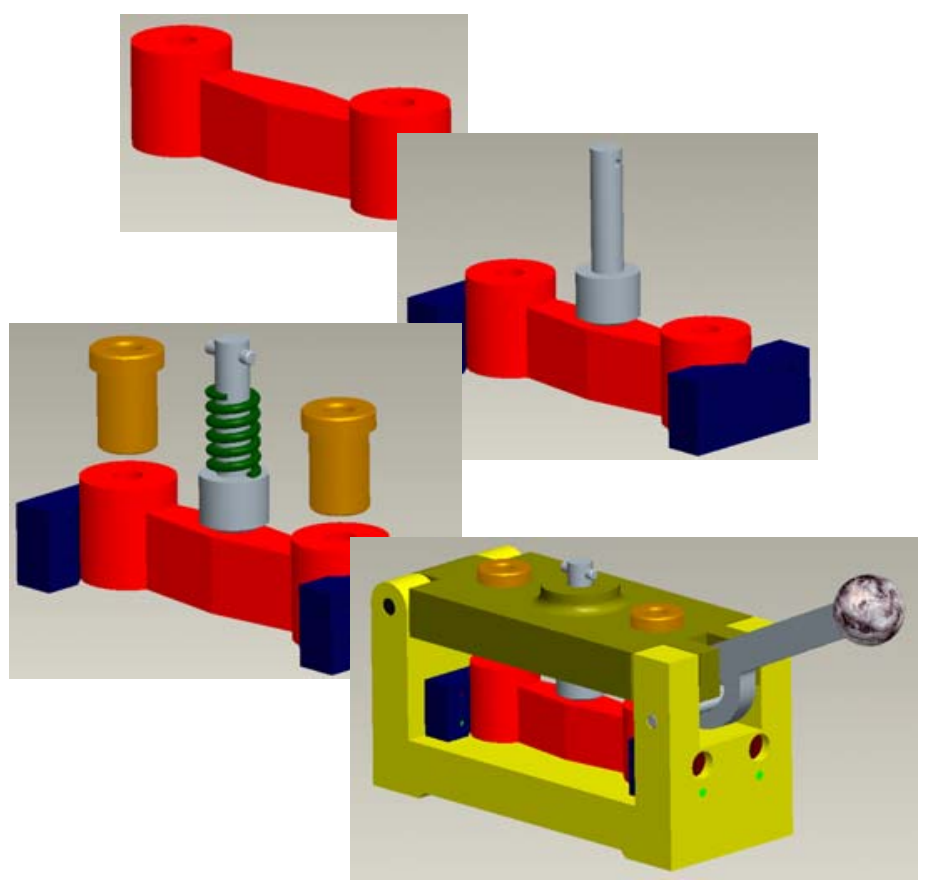

Slika 5.21. Karakteristični koraci pri sintezi pribora

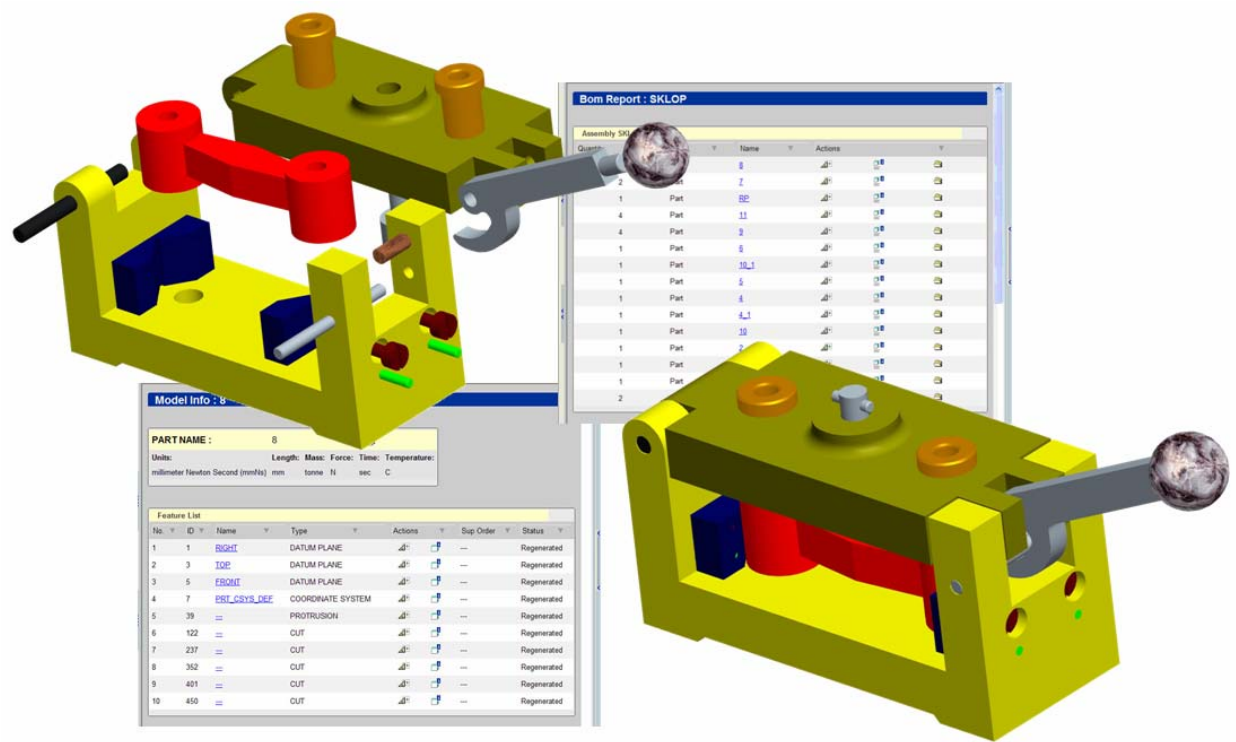

Slika 5.22. Izgled sastavljenog pribora i sastavnice elemenata u okruženju ProENGINEER-a

Nakon izvršenog komponovanja pribora vrši se analiza kolizija konstrukcije pribora. Prethodno spomenute vrste kolizija su prikazane za tri različita radna predmeta na slikama 5.23-5.25.

$\mathrm{Na}$ slici 5.23 je grafički predstavljena kolizija između sastavnih elemenata pribora. U ovom slučaju, prečnici odgovarajućih osovina veći su od 
prečnika otvora pojedinih elemenata pribora u koje se osovinice postavljaju radi međusobnog tačnog pozicioniranja elemenata pribora.

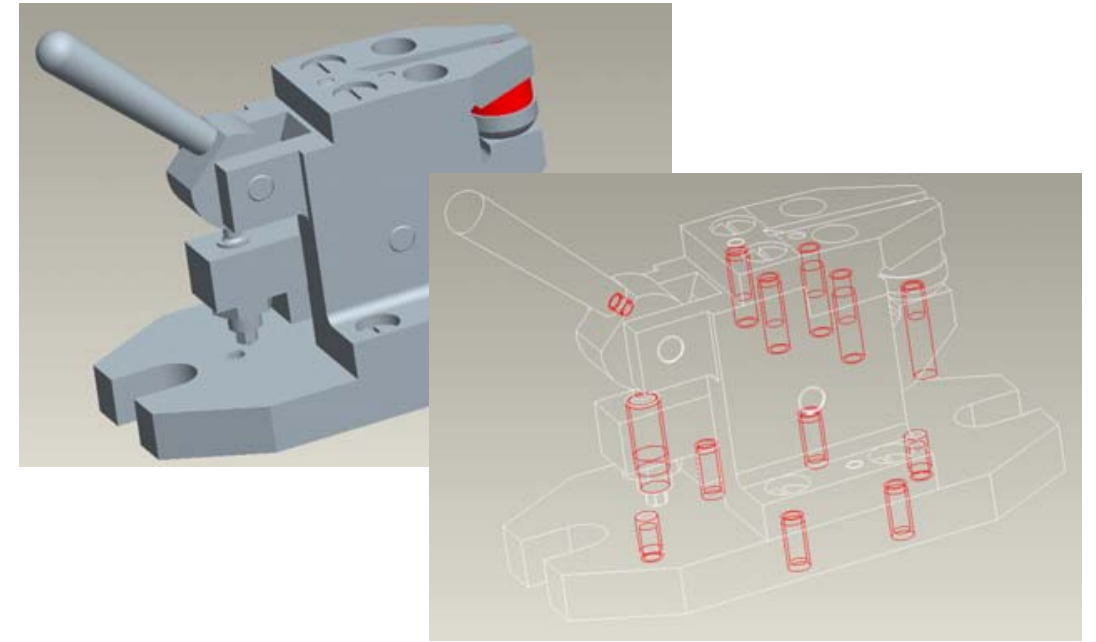

Slika 5.23. Grafička interpretacija kolizije između sastvanih elemenata pribora

Na slici 5.24. je prikazan primer detektovanja kolizije između elemenata pribora i radnog predmeta. U ovom slučaju je prečnik čepa uz pomoć kojeg se vrši pozicioniranje veći od prečnika otvora na radnom predmetu. Stoga, umesto minimalnog zazora koji treba da postoji između čepa i otvora, postoji preklop. Ovo onemogućava postavljanje - pozicioniranje radnog predmeta u pribor, nakon što pribor već bude projektovan i sastavljen.

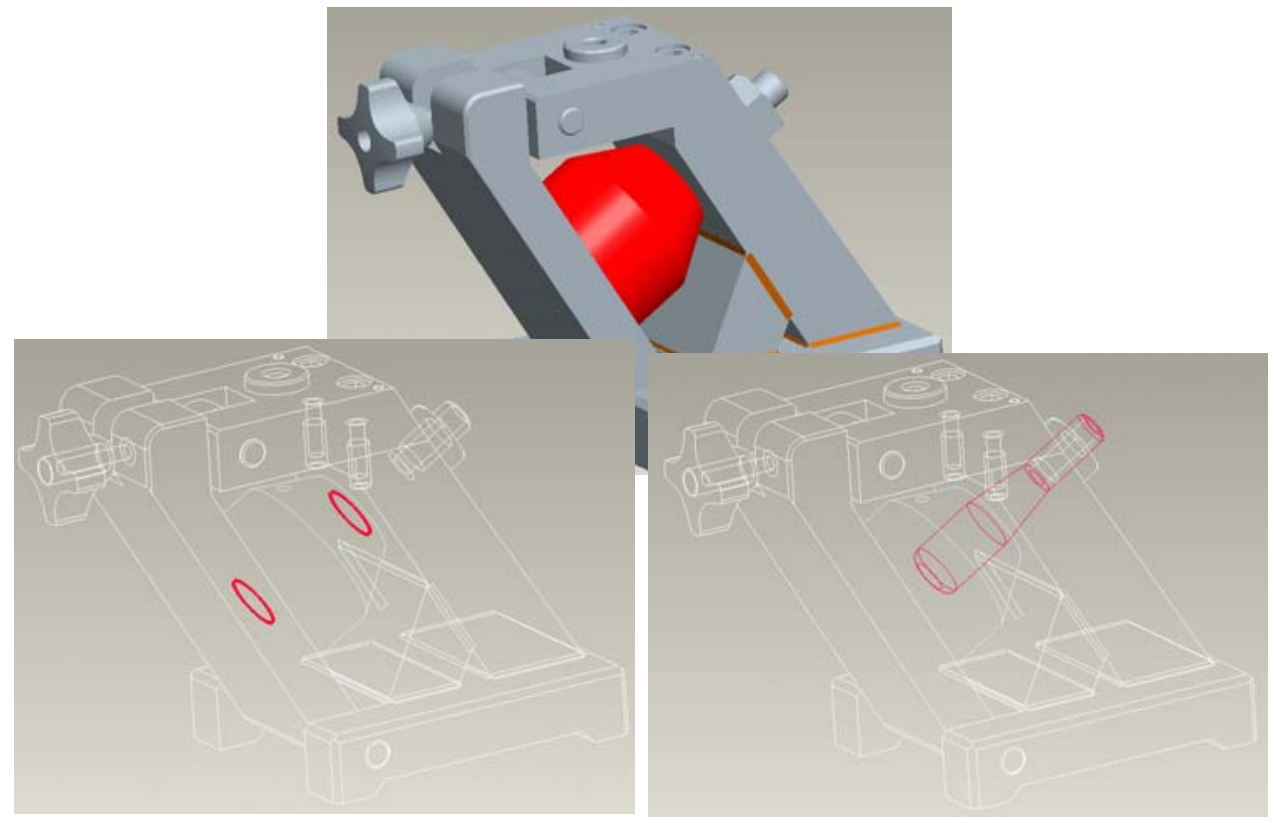

Slika 5.24. Grafička interpretacija kolizije između elemenata pribora i radnog predmeta 
Slika 5.25. daje grafički prikaz detektovane kolizije između reznog alata (glodala) i odgovarajućih elemenata pribora (stezne šape). Ovo ima za posledicu obradu elementa, a indirektno može dovesti i do oštećenja sklopa pribora, alata, mašine alatke, itd.

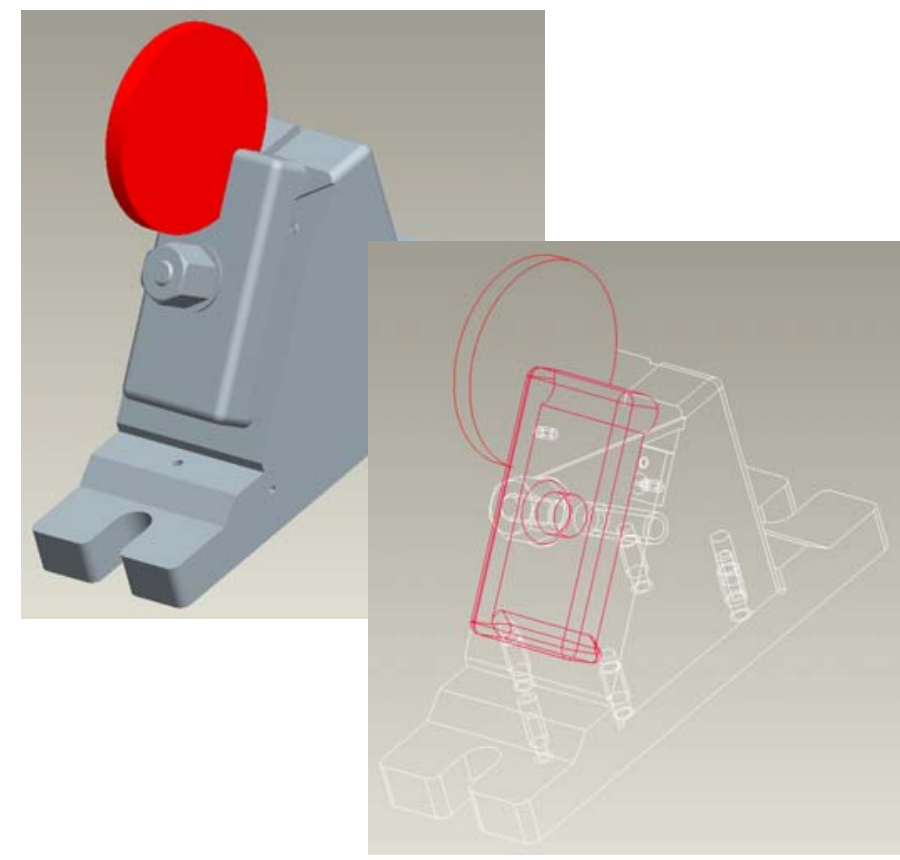

Slika 5.25. Grafička interpretacija kolizije između reznog alata i elemenata pribora

Pošto se izvrši komponovanje pribora, potrebno je pristupiti izradi izlazne informacije iz sistema automatizovanog projektovanja pribora. Izlaznu informaciju čini karta pribora (slika 5.26). U kartu pribora se unose sledeći podaci:

- ime i prezime projektanta - popunjava projektant unoseći svoje ime i prezime,

- datum projektovanja - popunjava se automatski na osnovu datuma kada su generisane karte,

- identifikaciona oznaka pribora - popunjava se automatski i predstavlja redni broj pribora u bazi podataka,

- pogon i odeljenje u kojem će se koristiti pribor - popunjava projektant na osnovu ulaznih informacija,

- naziv i oznaka radnog predmeta za koji se pribor projektuje - popunjava projektant na osnovu podataka iz ulaznih informacija, 


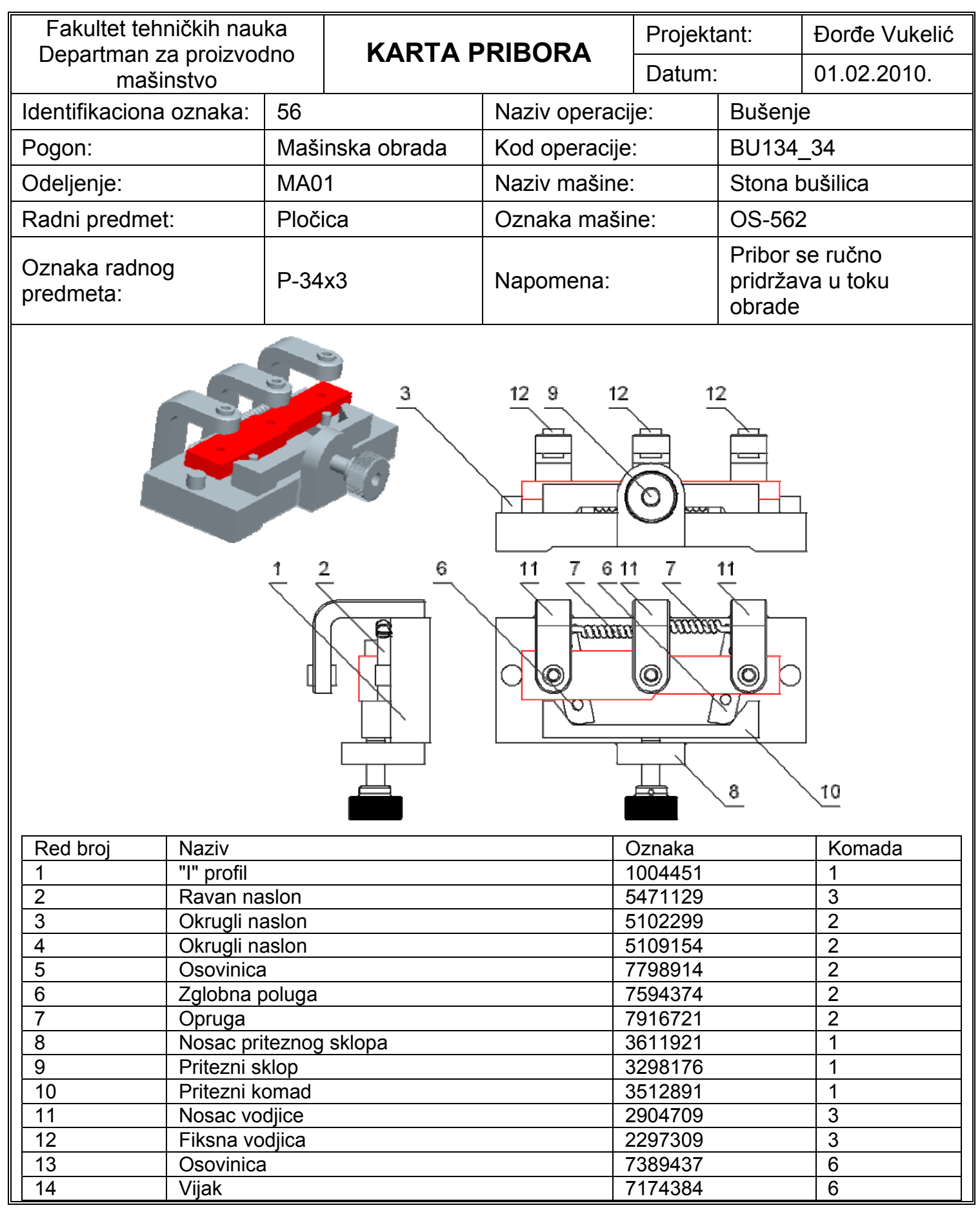

Slika 5.26. Karta pribora - izlazna dokumentacija iz sistema

- naziv i kod operacije - popunjava se automatski na osnovu unetih podataka u okviru modula za ulazne informacije,

- naziv i oznaka mašine na kojoj se izvodi obrada - popunjava se automatski na osnovu unetih podataka u okviru modula za ulazne informacije, 
- odgovarajuća napomena - popunjava projektant kako bi ukazao monteru pribora ili poslužiocu na mašini alatki na neke specifičnosti projektovane konstrukcije pribora,

- naziv, oznaka i broj komada sastavnih elemenata pribora - popunjava se interaktivno na osnovu sastavnice pribora generisane $u$ programskom paketu ProENGINEER,

- 3D i 2D sklopni crtež pribora - unosi ih projektant nakon što izabere karakterističan 3D pogled na pribor i definiše odgovarajuće 2D projekcije pribora u okviru programskog paketa ProENGINEER. 


\section{6}

\section{VERIFIKACIJA SISTEMA NA KONKRETNIM PRIMERIMA}

Teoretska analiza i prikaz sistema za optimizaciju i projektovanje pribora obuhvaćeni su četvrtim i petim poglavljem. Da bi objašnjenje bilo u celini završeno, neizbežno je rad celog sistema prikazati u realnim uslovima. $U$ ovom poglavlju opisana su testiranja postavljenog sistema na konkretnim primerima obrade radnih predmeta.

\subsection{ULAZNI PODACI}

$\mathrm{Na}$ osnovu crteža radnog predmeta i tehnološkog procesa njegove izrade definišu se ulazni podaci za automatizovano projektovanje i oprimizaciju konstrukcije pribora. Ulazni podaci su dati za tri primera i to za operacije:

- bušenja otvora na pločici 2 x Ø12 H8 (slika 6.1),

- bušenja otvora na disku 3 x Ø14 H6 (slika 6.2),

- glodanja ravne površine pločice $6.2^{ \pm 0.1} \times 20^{ \pm 0.14}$ (slika 6.3).

U prvom slučaju izvodi se operacija bušenja dva otvora na konvencionalnoj horizontalnoj jednovretenoj bušilici. Vrši se izrada dva otvora na jednom radnom predmetu jednim alatom za obradu rezanjem - zavojnom burgijom. Obrada se izvodi sa brzinom rezanja od 35 [m/min] i sa pomakom od 0,3 [mm/obr]. Pribor se postavlja na radni sto mašine i u toku obrade se ručno pridržava. Radni predmet se obrađuje u seriji od 1500 komada. Radni predmet se pozicionira i steže preko spoljašnjih površina, a potrebno mu je oduzeti svih šest stepeni slobode kretanja po metodu pozicioniranja 3-2-1. Pravac dejstva 
sile stezanja u odnosu na primarnu baznu površinu je upravan, a sila stezanja je upravna na ravan momenta rezanja. Pogon stezanja je ručni.
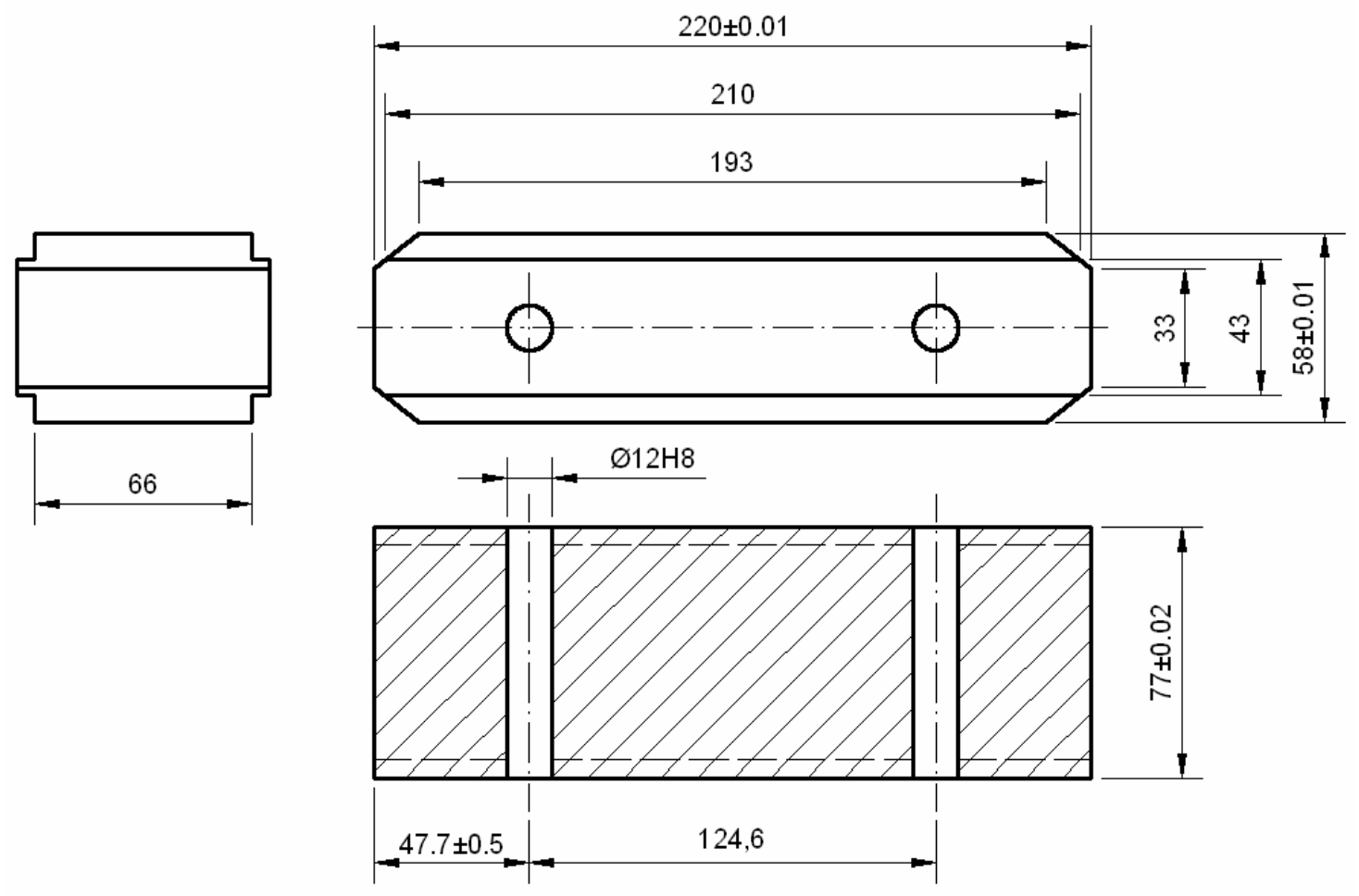

Slika 6.1. Radni predmet-pločica
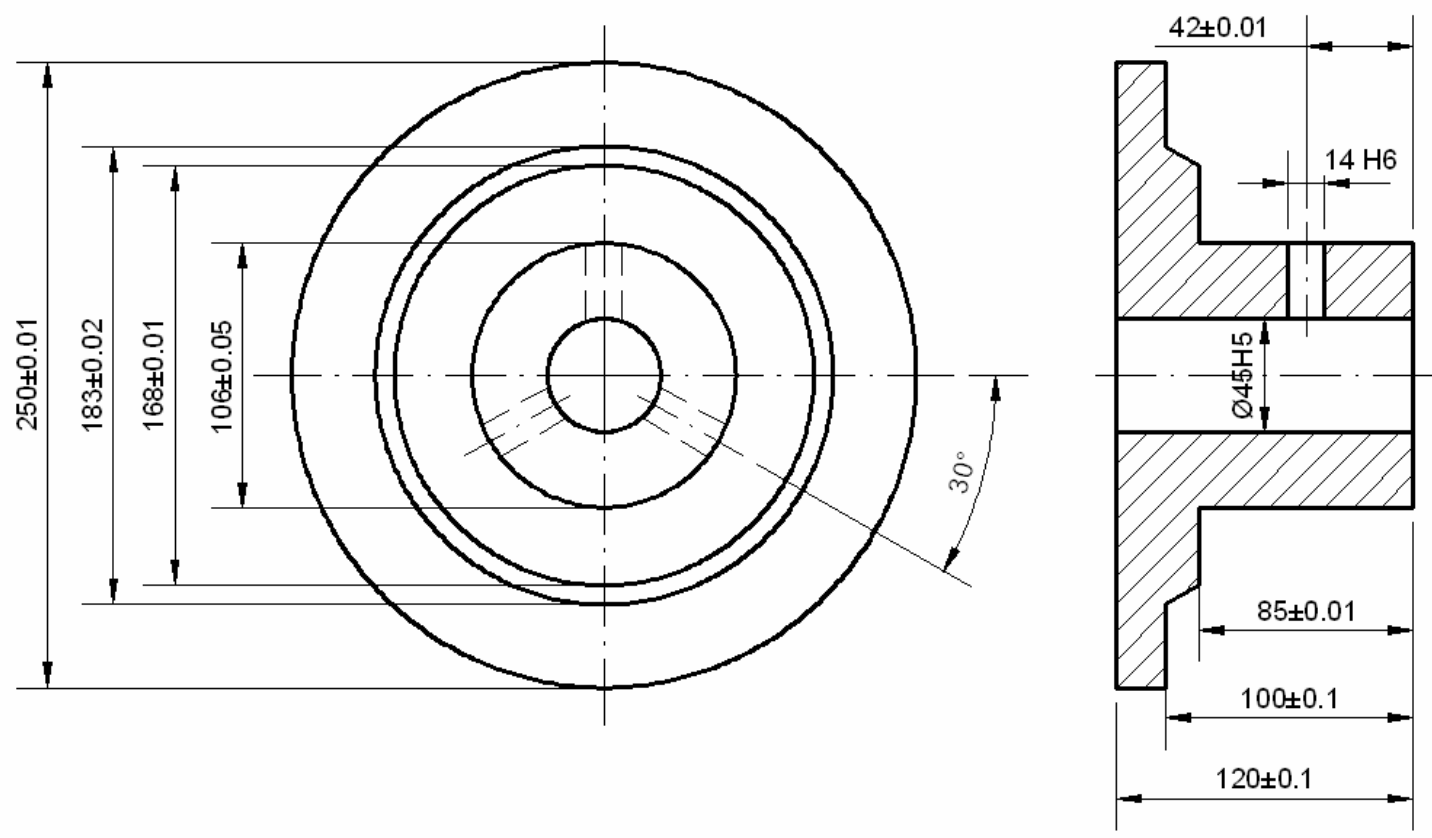

Slika 6.2. Radni predmet - prirubnica 
U drugom slučaju se izvodi operacija bušenja tri otvora na konvencionalnoj vertikalnoj jednovretenoj bušilici. Vrši se izrada tri otvora raspoređena po krugu na jednom radnom predmetu jednim alatom za obradu rezanjem. Alat za obradu rezanjem je zavojna burgija. Obrada se izvodi sa brzinom rezanja od $30[\mathrm{~m} / \mathrm{min}]$ i sa pomakom od 0,2 [mm/obr]. Pribor se postavlja na radni sto mašine i u toku obrade se ručno pridržava. Proizvodnja je serijska, a veličina serije je 70000 komada. Radni predmet se pozicionira i preko spoljašnje i preko unutrašnje površine. Radnom predmetu je potrebno oduzeti pet stepeni slobode kretanja po metodu pozicioniranja 4-1-1. Stezanje se izvodi preko spoljašnje površine. Pravac dejstva sile stezanja u odnosu na primarnu baznu površinu je upravan. Sila stezanja je upravna na ravan momenta rezanja. Pogon stezanja je ručni.

$U$ trećem slučaju se izvodi operacija istosmernog obimnog glodanja ravne površine na numerički upravljanoj glodalici. Alat za obradu rezanjem je valjčasto glodalo sa pravim zubima. Obrada se izvodi sa brzinom rezanja od $20[\mathrm{~m} / \mathrm{min}]$ i sa pomakom po zubu od $0,15[\mathrm{~mm} / \mathrm{z}]$. Pribor se postavlja na radni sto mašine i u toku obrade se elementi pribora pričvršćuju za radni sto mašine. Proizvodnja je velikoserijska, a veličina serije je 20000 komada. Radni predmet se pozicionira i steže preko spoljašnje površine. Radnom predmetu je potrebno oduzeti šest stepeni slobode kretanja po metodu pozicioniranja 3-21. Pravac dejstva sile stezanja u odnosu na primarnu baznu površinu je paralelan. Sila stezanja je paralelna sa ravni momenta rezanja. Pogon stezanja je ručni.
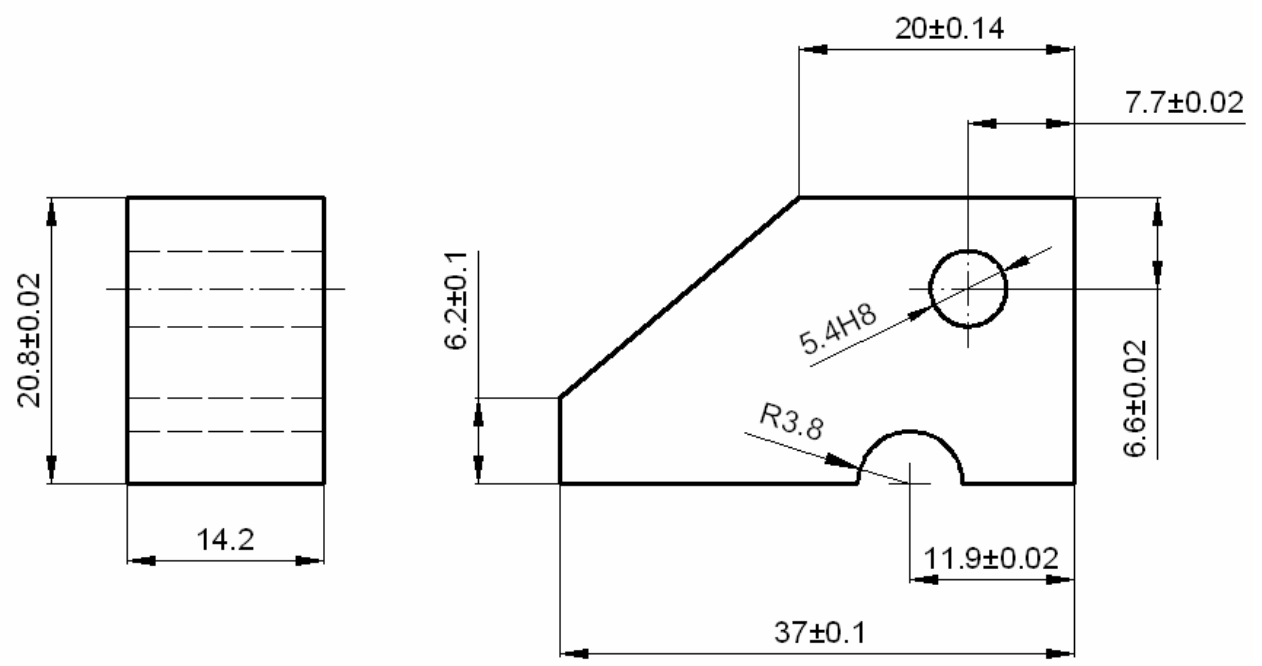

Slika 6.3. Radni predmet - pločica 


\subsection{DEFINISANJE POVRŠINA ZA POZICIONIRANJE I STEZANJE}

Za radne predmete prikazane na slikama 6.1-6.3 u prvom koraku se vrši unos ulaznih informacija. Ulazne informacije se unose na osnovu crteža radnog predmeta i tehnoloških i geometrijskih ograničenja definisanih tehnološkim postupcima izrade delova. Ove ulazne informacije se kodiraju na osnovu formi prikazanih u prethodnom poglavlju. Za unete ulazne informacije generišu se moguće šeme pozicioniranja i stezanja u okviru modula za optimizaciju konstrukcije pribora.

U prvom slučaju moguća je šema baziranja data na slici 6.4 . Pozicioniranje radnog predmeta se vrši preko tri ravne površine:

- A - primarna bazna površina oduzima radnom predmetu tri stepena slobode kretanja,

- B - sekundarna bazna površina oduzima radnom predmetu dva stepena slobode kretanja,

- C - tercijarna bazna površina oduzima radnom predmetu jedan stepen slobode kretanja.

Greška pozicioniranja za prikazani metod pozicioniranja je jednaka nuli. Stezanje radnog predmeta je moguće izvesti preko površine $D$ paralelne sa površinom $A$.

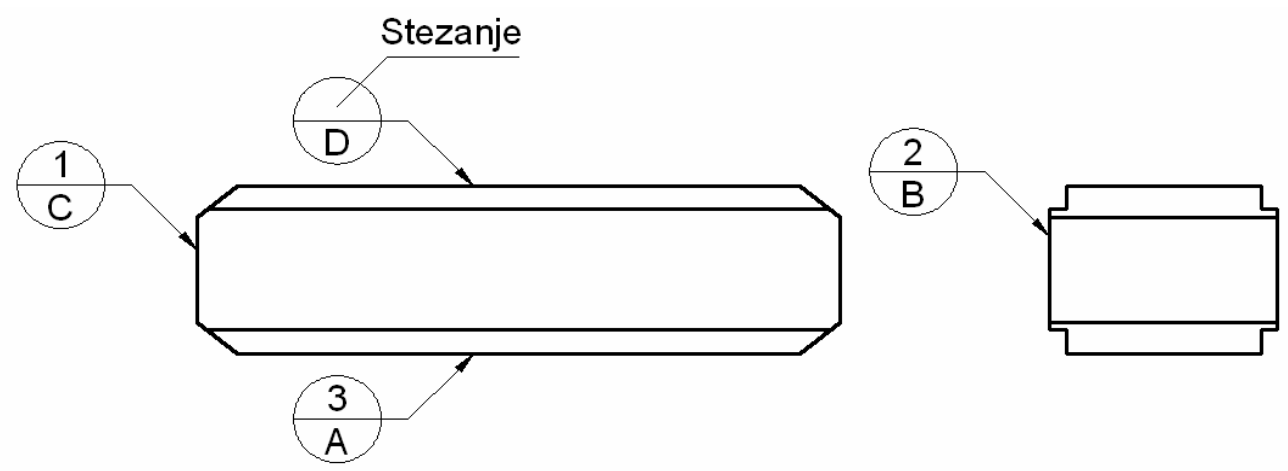

Slika 6.4. Definisanje šeme pozicioniranja i stezanja stezanja.

U drugom slučaju moguće je definisati nekoliko šema baziranja $i$ 

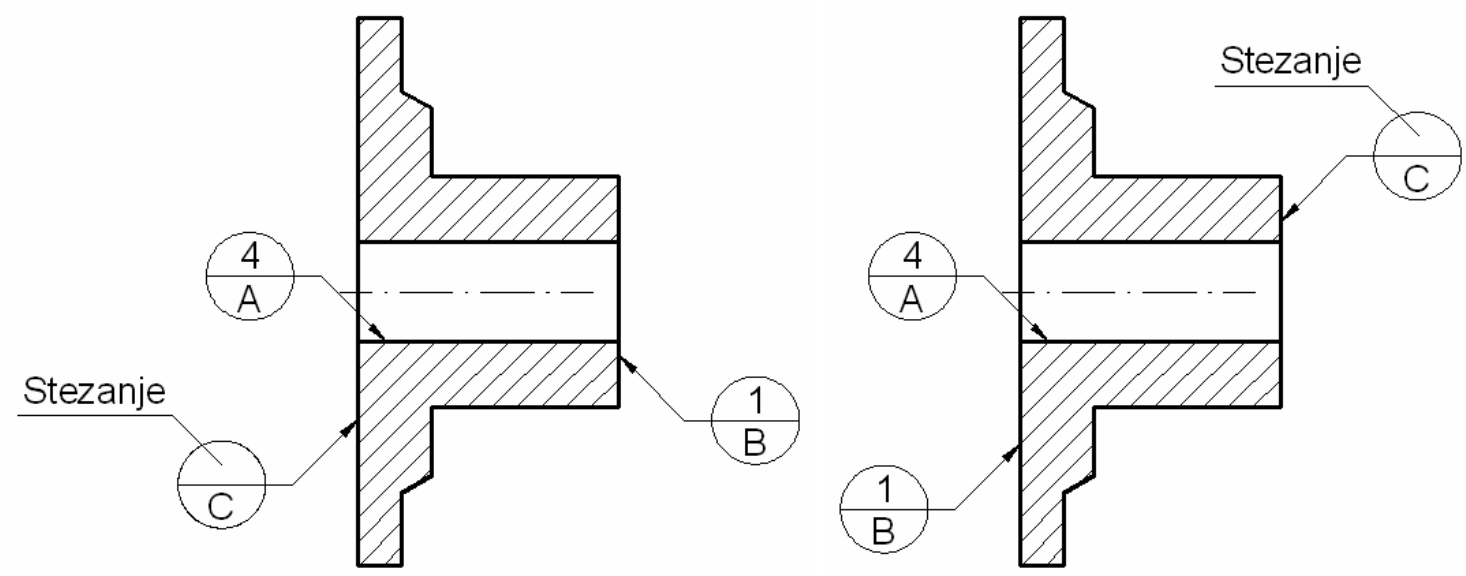

Slika 6.5. Primer dve strategije pozicioniranja radnog predmeta

Na slici 6.5. prikazane su dve strategije pozicioniranja i stezanja istog radnog predmeta. $U$ oba slučaja radnom predmetu se oduzima pet stepeni slobode, i to preko površine:

- A - primarna bazna površina oduzima radnom predmetu četiri stepena slobode kretanja,

- B - sekundarna bazna površina oduzima radnom predmetu jedan stepen slobode kretanja.

Prema prvoj strategiji pozicioniranja, greška pozicioniranja je jednaka nuli. Prema drugoj startegiji pozicioniranja, usled nepoklapanja konstrukcione i tehnološke baze, javlja se greška pozicioniranja čiji je izvor u toleranciji obrade mere $120 \mathrm{~mm}$ (slika 6.2). Greška pozicioniranja je jednaka $\Delta_{p}=0.2 \mathrm{~mm}$, što je veće od dozvoljene tolerancije izrade $\mathrm{T}=0.02 \mathrm{~mm}$, tako da je radni predmet moguće pozicionirati prema prvoj strategiji kako bi se dobili otvori sa dozvoljenim tolerancijama izrade.

Stezanje radnog predmeta je moguće izvesti preko površine C paralelene sa površinom $A$.

Prethodne strategije podrazumevaju da se operacije bušenja otvora izvode jednim alatom i uz upotrebu podeonog uređaja. $U$ istoj operaciji ( $u$ istom stezanju) radni predmet se dovodi u novi radni položaj u odnosu na alat. Ovi uređaji, osim pomeranja radnog predmeta u novi položaj, omogućavaju i vršenje podele. Okretni elementi se primenjuju kada se $u$ istom stezanju obrađuju dve ili više identičnih površina raspoređenih po krugu, istim reznim alatom. 

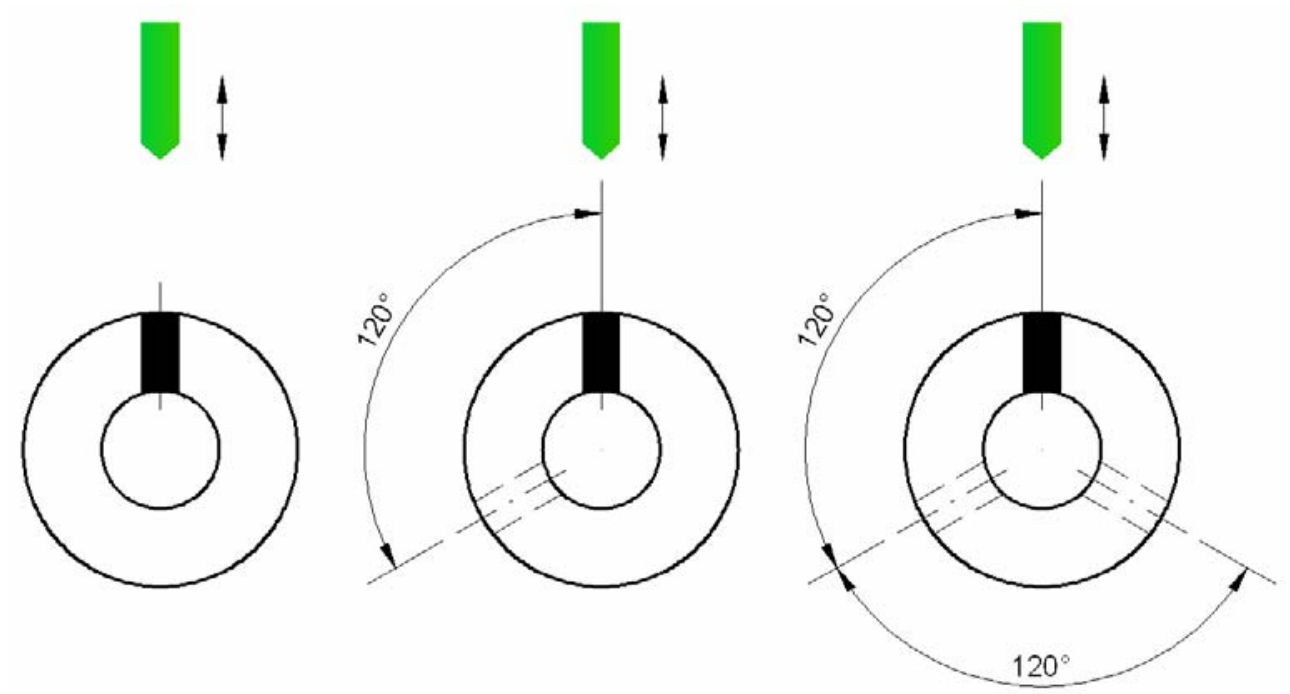

Slika 6.6. Karakteristični zahvati pri bušenju otvora

U trećem slučaju moguća šema baziranja je data na slici 6.7 . Pozicioniranje radnog predmeta se vrši preko tri ravne površine:

- A - primarna bazna površina oduzima radnom predmetu tri stepena slobode kretanja,

- B - sekundarna bazna površina oduzima radnom predmetu dva stepena slobode kretanja,

- C - tercijarna bazna površina oduzima radnom predmetu jedan stepen slobode kretanja.

Greška pozicioniranja za prikazani metod pozicioniranja je jednaka nuli. Stezanje radnog predmeta je moguće izvesti preko površine $D$ paralelne sa površinom $\mathrm{C}$.

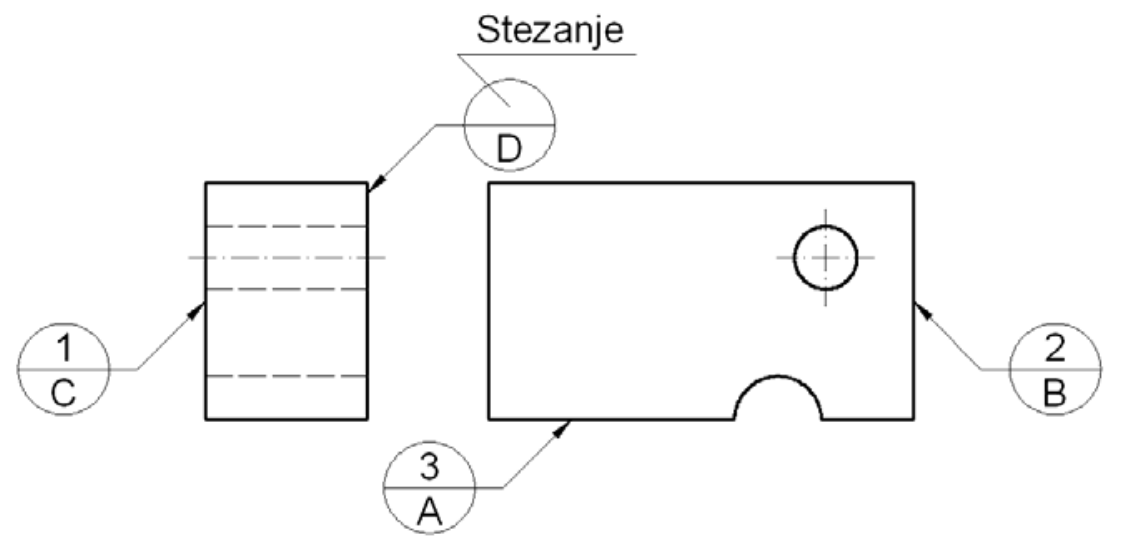

Slika 6.7. Definisanje šeme pozicioniranja i stezanja 
Radni predmet je potrebno orijentisati $u$ prostoru $u$ zavisnosti od tehnološkim postupkom definisanog položaja alata za obradu rezanjem i mašine alatke na kojoj će se vršiti obrada. U konkretnom slučaju, mašinska obrada obimnog glodanja izvodi se na horizontalnoj glodalici sa standardnim valjčastim glodalom. Da bi se obezbedila obrada tačno definisane površine, potrebno je radni predmet zaokrenuti za određeni ugao kako bi se obezbedila horizontalnost površine koja će se obrađivati.
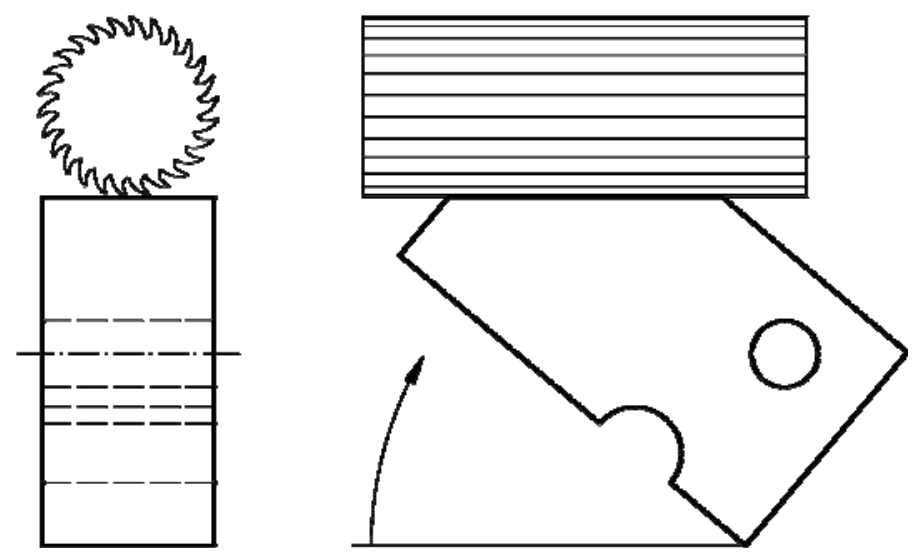

Slika 6.8. Položaj radnog predmeta u priboru

Uzimajući u obzir dimenzije radnog predmeta, površinu radnog predmeta na kojoj se vrši obrada i raspoloživi prostor na mašini alatki (radni prostor mašine), moguće je predvideti izradu pribora za obradu više predmeta obrade. U konkretnom slučaju je predviđena istovremena obrada šest radnih predmeta. Na ovaj način se osetno skraćuje vreme za obradu serije delova (osetno je smanjenje pomoćnog vremena obrade).

Stezanje je moguće ostvariti preko površine D koja je paralelna sa površinom C. Stezanje je moguće izvesti višepoložajnim rednim stezanjem sa jednog mesta vrši se stezanje većeg broja radnih predmeta odjednom. Kod rednog stezanja, sila stezanja se prenosi sa jednog radnog predmeta na druge koji su postavljeni u red.

\subsection{DEFINISANJE TAČAKA ZA POZICIONIRANJE I STEZANJE}

Optimizacija položaja elemenata za pozicioniranje i stezanje vrši se na osnovu svih sila koje dejstvuju na radni predmet u toku obrade, uz pomoć genetskog algoritma. Najvažniji korak koji je potrebno sprovesti jeste 
definisanje geometrijskih ograničenja površina za pozicioniranje i stezanje na kojima treba da se definišu odgovarajuće tačke pozicioniranja i stezanja. Prvo se definišu glavni koordinatni sistemi (slike 6.9-6.11), a potom i položaj čvorne tačke u odnosu na njih.
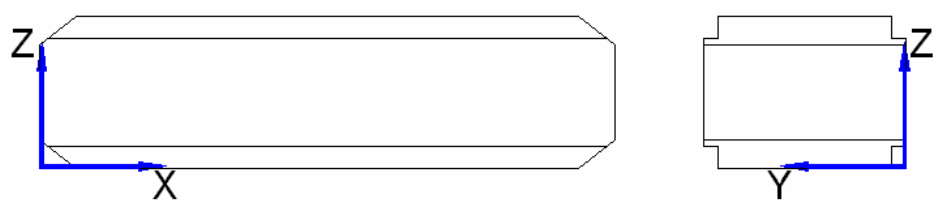

Slika 6.9. Položaj glavnog koordinatnog početka za prvi radni predmet
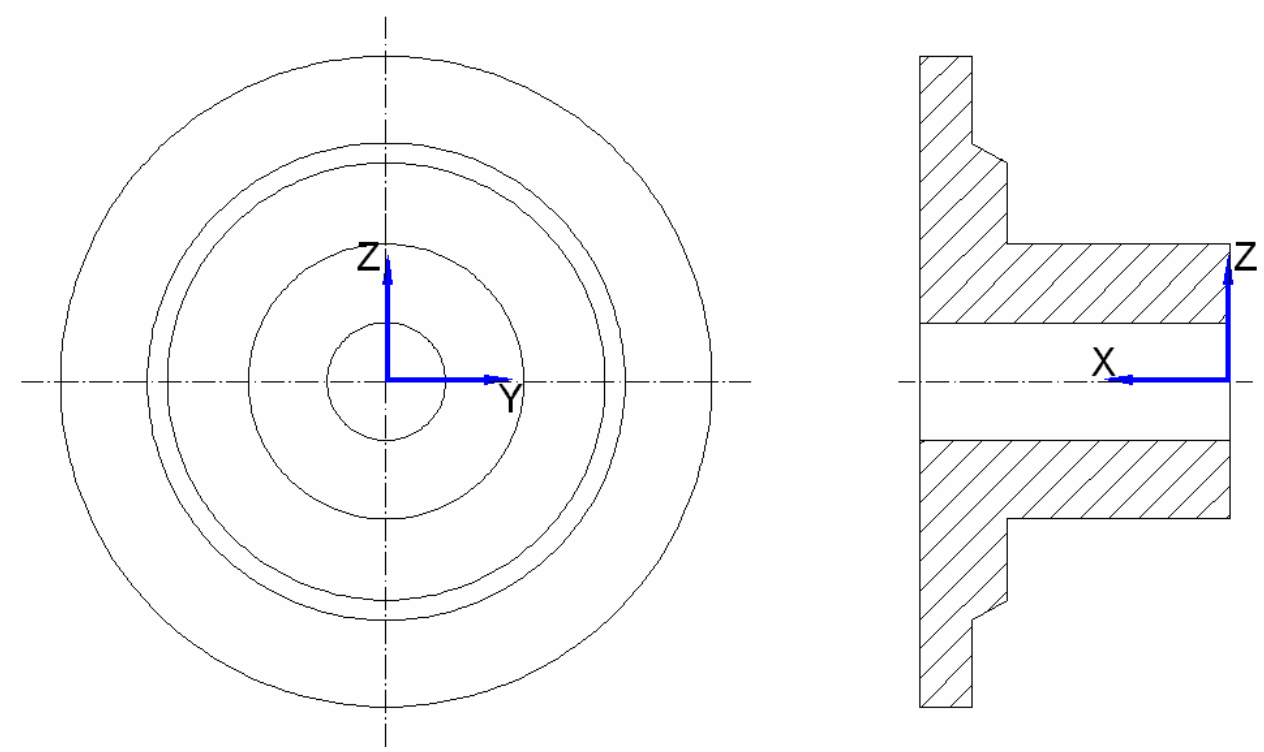

Slika 6.10. Položaj glavnog koordinatnog početka za drugi radni predmet
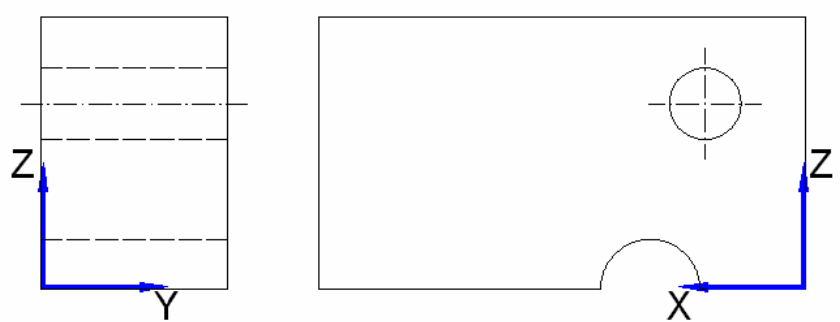

Slika 6.11. Položaj glavnog koordinatnog početka za treći radni predmet

U odnosu na čvornu tačku (lokalni koordinatni sistem) potrebno je jednoznačno definisati geometriju baznih i steznih površina, preko njihovih karakterističnih dimenzija. 
Karakteristični oblici površina, koordinate čvornih tačaka i karakteristične dimenzije površina za pozicioniranje i stezanje dati su za sva tri radna predmeta u tabelama 6.1-6.3, respektivno.

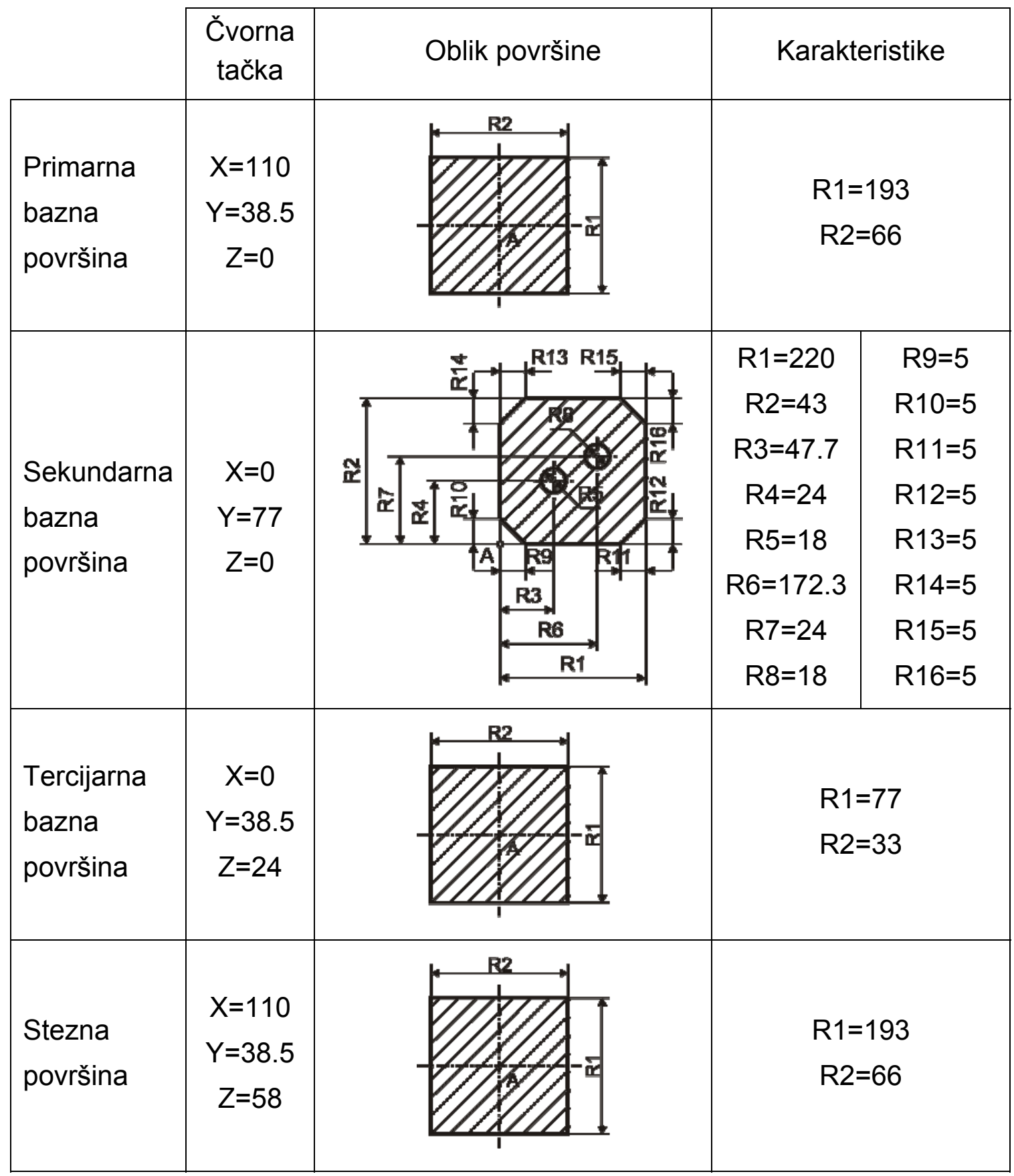

Tabela 6.1. Koordinate čvorne tačke, oblik bazne i stezne površine, karakteristične dimenzije baznih i steznih površina

U prvom primeru posebnu pažnju treba obratiti na definisanje sekundarne bazne površine. Budući da se radi o bušenju otvora a ne rupe, treba obratiti pažnju na to da alat s jedne strane ulazi u radni predmet a sa 
druge izlazi, kako se ne bi desio slučaj da se bazni element postavi na trajektoriju alata (slika 6.12). Prilikom definisanja primarne i tercijarne bazne površine, ovaj problem se ne javlja, tako da se one mogu definisati pomoću šeme u obliku pravougaonika.

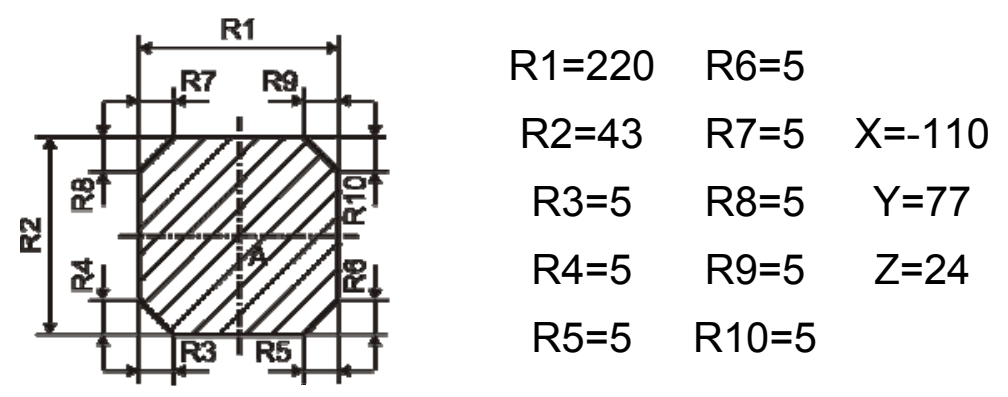

Slika 6.12. Neispravno definisanje sekundarne bazne površine

\begin{tabular}{|c|c|c|c|}
\hline & $\begin{array}{l}\text { Čvorna } \\
\text { tačka }\end{array}$ & Oblik površine & Karakteristike \\
\hline $\begin{array}{l}\text { Primarna } \\
\text { bazna } \\
\text { površina }\end{array}$ & $\begin{array}{l}X=0 \\
Y=0 \\
Z=0\end{array}$ & 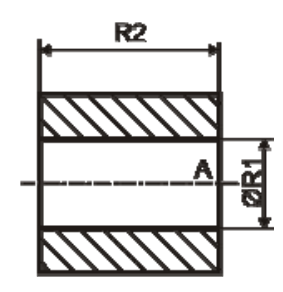 & $\begin{array}{l}\varnothing R 1=45 \\
R 2=120\end{array}$ \\
\hline $\begin{array}{l}\text { Sekundarna } \\
\text { bazna } \\
\text { površina }\end{array}$ & $\begin{array}{l}X=0 \\
Y=0 \\
Z=0\end{array}$ & & $\begin{array}{c}R 1=53 \\
R 2=22.5\end{array}$ \\
\hline $\begin{array}{l}\text { Stezna } \\
\text { površina }\end{array}$ & $\begin{array}{c}X=120 \\
Y=0 \\
Z=0\end{array}$ & 8 & $\begin{array}{l}\mathrm{R} 1=125 \\
\mathrm{R} 2=22.5\end{array}$ \\
\hline
\end{tabular}

Tabela 6.2. Koordinate čvorne tačke, oblik bazne i stezne površine, karakteristične dimenzije baznih i steznih površina 


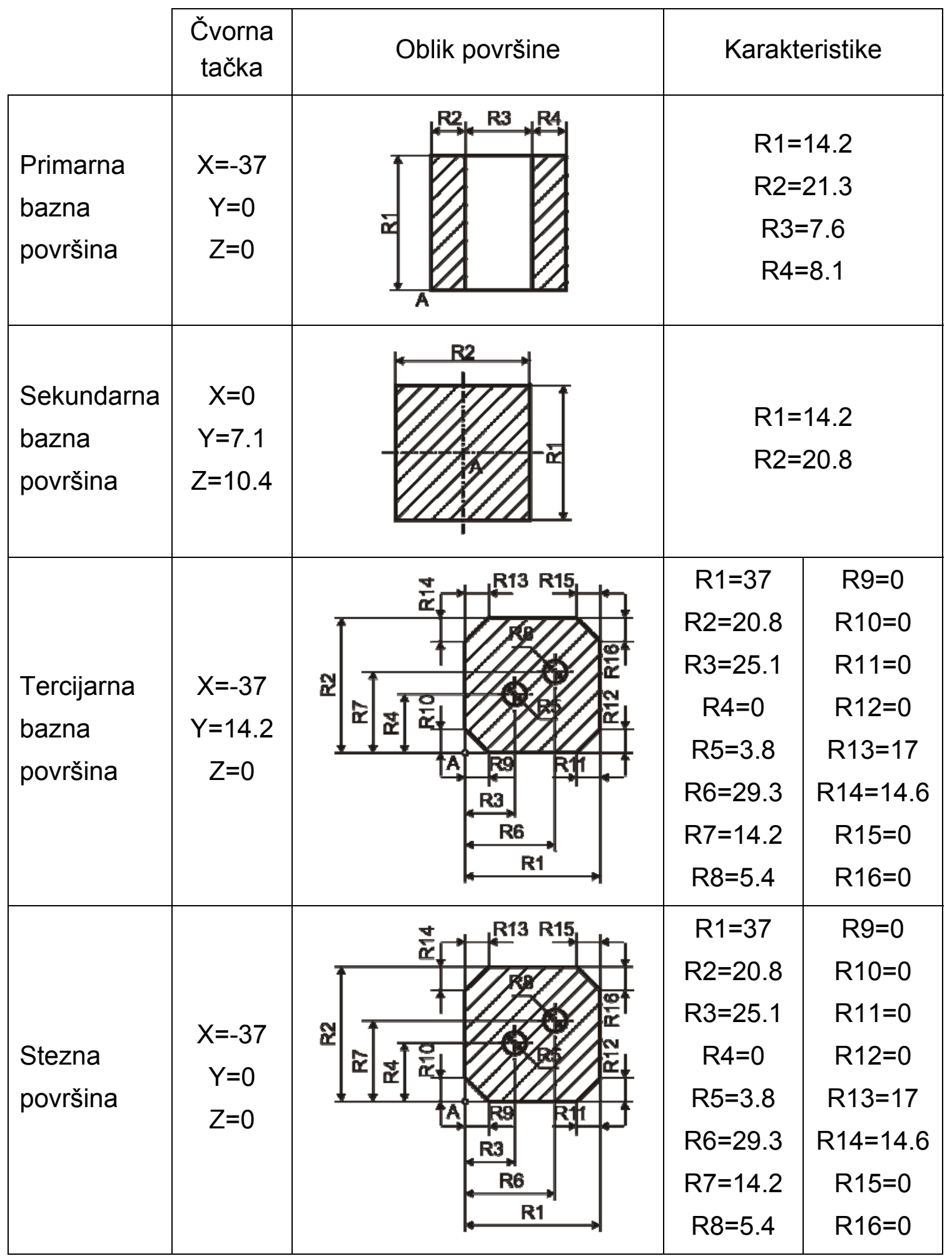

Tabela 6.3. Koordinate čvorne tačke, oblik bazne i stezne površine, karakteristične dimenzije baznih i steznih površina

Nakon što se definišu čvorne tačke, oblici i karakteristične dimenzije površina za pozicioniranje i stezanje sprovodi se procedura optimizacije 
položaja elemenata za pozicioniranje i stezanje i pritom uzima u obzir da je funkcija cilja minimizacija sila koje deluju na radni predmet u toku obrade. Kao kriterijum zaustavljanja odabran je ukupni broj iteracija koji je iznosio 10000 pokušaja (slika 6.13).

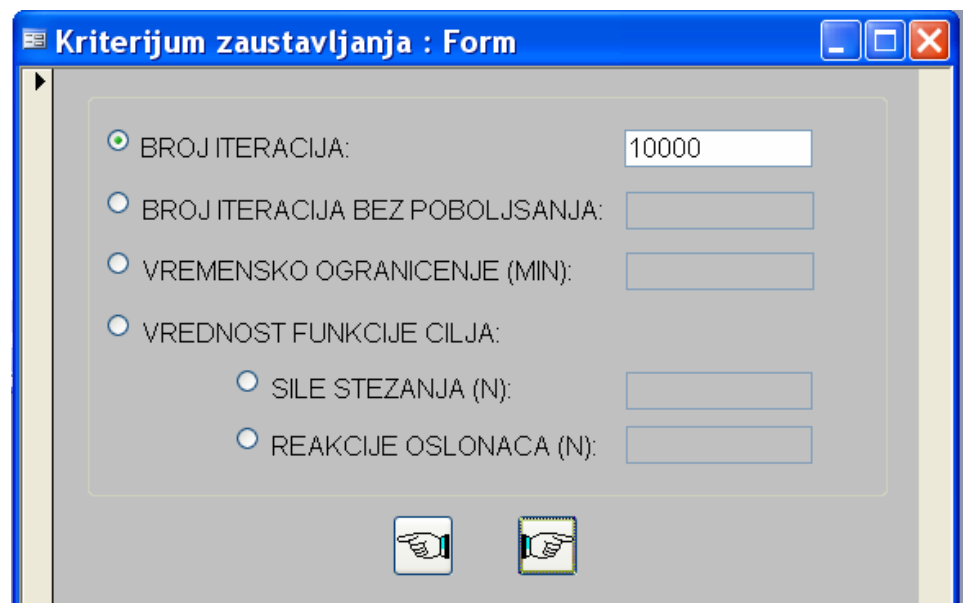

Slika 6.13. Definisanje kriterijuma zaustavljanja

Najbolji članovi populacije predstavljaju rešenja optimalne pozicije elemenata za pozicioniranje i stezanje. Na slici 6.14. su prikazane koordinate elemenata za pozicioniranje i stezanje za prvi i treći primer.

\begin{tabular}{|c|c|c|c|c|c|c|c|}
\hline Pozicioniranje & $x$ & $\mathrm{Y}$ & $Z$ & & & & \\
\hline L1 & 47.7 & 25.5 & 0 & & & & \\
\hline L2 & 172.3 & 25.5 & 0 & & & & \\
\hline L3 & 110 & 41 & 0 & & & & \\
\hline L4 & 56 & 77 & 24 & Pozicioniranje & $\mathrm{x}$ & Y & Z \\
\hline L5 & 164 & 77 & 24 & L1 & 29.9 & 4.2 & 0 \\
\hline \multirow[t]{2}{*}{ L6 } & \multirow[t]{2}{*}{0} & \multirow[t]{2}{*}{38.5} & \multirow{2}{*}{24} & L2 & 4.1 & 4.2 & 0 \\
\hline & & & & L3 & 21.5 & 10 & 0 \\
\hline Stezanje & $x$ & \multirow{2}{*}{$Y$} & $Z$ & L4 & 0 & 4.2 & 10.2 \\
\hline C1 & 47.7 & & 58 & L5 & 0 & 10 & 10.2 \\
\hline $\mathrm{C} 2$ & 172.3 & 25.5 & 58 & L6 & 11.9 & 14.2 & 8.1 \\
\hline & & & & Stezanje & $x$ & Y & Z \\
\hline & & & & C1 & 11.9 & 0 & 8.1 \\
\hline
\end{tabular}

Slika 6.14. Pozicije elemenata za pozicioniranje i stezanje

U drugom slučaju optimizaciju položaja elemenata za pozicioniranje i stezanje nije potrebno sprovesti. Budući da se u ovom slučaju pozicioniranje izvodi preko primarne bazne površine otvora i da se u ovom slučaju za 
pozicioniranje upotrebljavaju čep ili trn, nije potrebno sprovesti proceduru optimizacije. Kontakt unutrašnje površine radnog predmeta i dugog čepa ili trna će uvek biti po izvodnici cilindra. U okviru segmenta za sintezu pribora bira se adekvatan element za pozicioniranje na osnovu dimenzija otvora (prečnika i dužine).

\subsection{IZBOR ELEMENATA PRIBORA}

U okviru modula za sintezu pribora dobijaju se elementi pribora (svi ili deo) na osnovu kojih je moguće izvršiti sintezu potrebnih konstrukcija pribora. $\mathrm{Na}$ slici 6.15. su date forme sa elementima pribora razdeljenim po funkcionalnim grupama za sva tri radna predmeta.

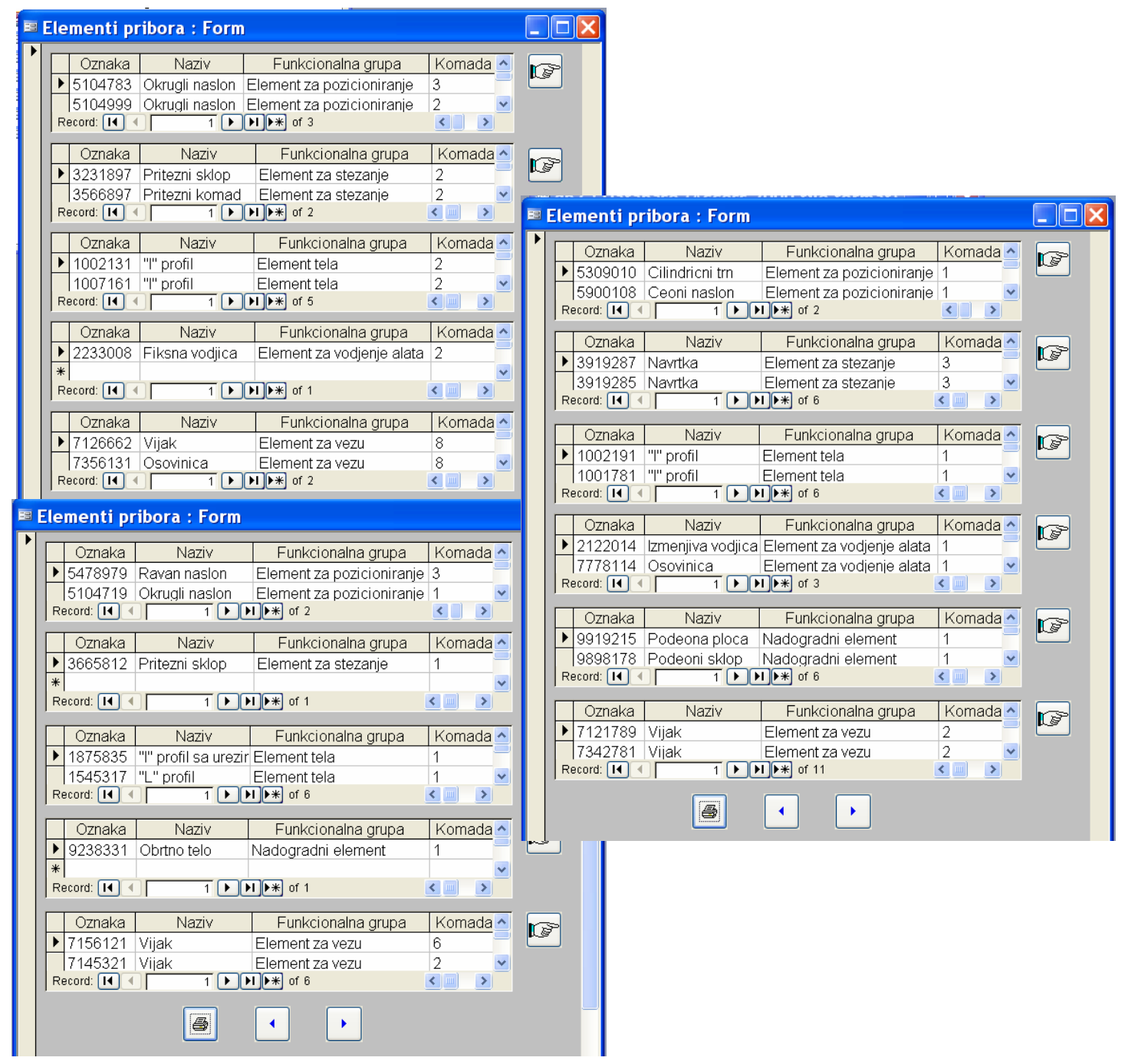

Slika 6.15. Forme sa prikazom mogućih elemenata pribora 


\subsection{DEFINISANJE IZLAZNIH INFORMACIJA}

Biranje potrebnih elemenata se vrši u interaktivnom radu. Projektant sukcesivno bira elemente pribora (kako je ranije opisano) i raspoređuje na odgovarajuće mesto na crtežu pribora u odnosu na radni predmet. U slučaju da ima više ponuđenih rešenja, projektant odlučuje koje će rešenje usvojiti. Ako dobijeni rezultat $u$ toku oblikovanja konstrukcije zahteva korekcije, projektant neposredno unosi neophodne dopune ili izmene i produžava proces automatizovanog projektovanja sve dok ne dobije finalnu konfiguraciju pribora.

Na slici 6.16. su prikazani karakteristični koraci u sintezi pribora za prvi radni predmet. Kompletnu konstrukciju pribora je moguće sastaviti na osnovu elemenata koje nudi programsko rešenje sistema.

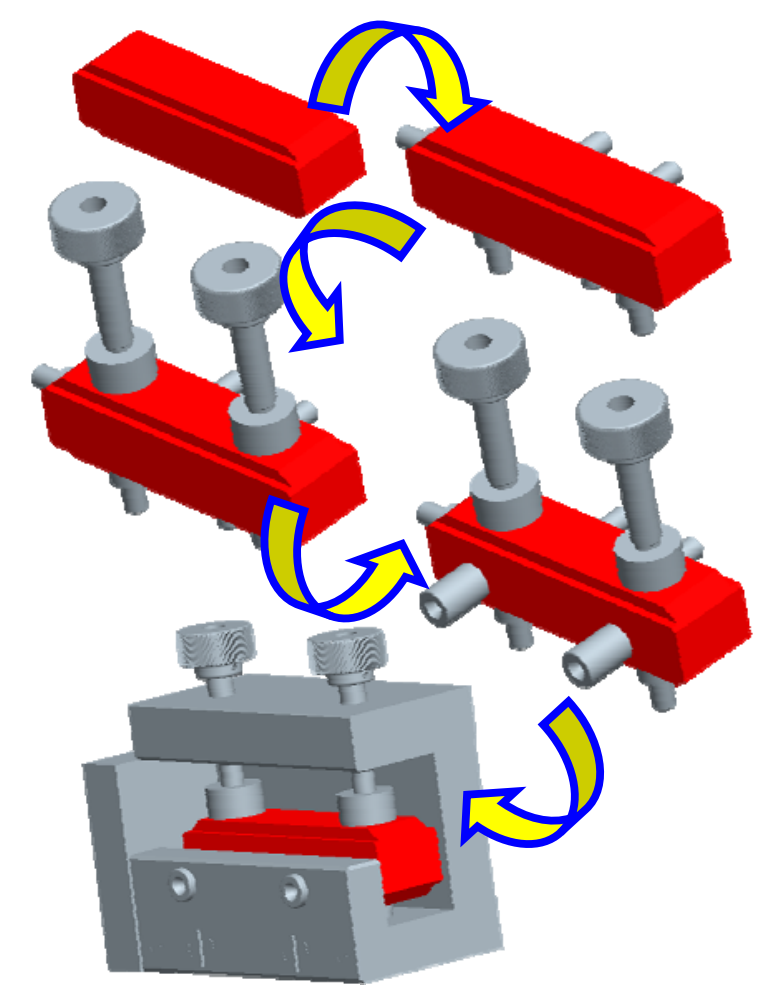

Slika 6.16. Karakteristični koraci u sastavljanju pribora

$\mathrm{U}$ pribor se postavlja jedan radni predmet. Pozicioniranje radnog predmeta se izvodi pomoću odgovarajućih okruglih naslona tako da se predmetu oduzima svih šest stepeni slobode kretanja. Stezanje se izvodi uz pomoć složenog mehanizma za stezanje (priteznog sklopa i priteznog komada). Pritezni sklop se sastoji od nareckane ručice, osovine i čivije. Izvorna sila se dobija ručnim okretanjem nareckane navrtke i prenosi se dalje preko 
osovine i priteznog komada na radni predmet. Svaki od dva pritezna sklopa dejstvuje na radni predmet tačno naspram mesta postavljanja okruglih čepova za pozicioniranje. Telo pribora se satoji od pet odgovarajućih I-profila. Profili su međusobno spojeni pomoću zavrtnjeva i tačno pozicionirani pomoću čivija. Za tačno vođenje zavojne burgije koriste se dve fiksne vođice unutrašnjeg prečnika, koji odgovara prečniku otvora, koje treba izbušiti. Na jednom I-profilu su montirane dve vođice na međusobnom rastojanju koje odgovara rastojanju otvora na radnom predmetu. Za drugi, treći i četvrti l-profil se vezuju okrugli nasloni za pozicioniranje preko primarne, sekundarne i tercijarne bazne površine. Posebnu pažnju treba posvetiti I-profilu koji nosi dva okrugla naslona za pozicioniranje preko sekundarne bazne površine (slika 6.17). Na ovom profilu je potrebno prethodno izbušiti otvore nekoliko milimetara većeg prečnika u odnosu na prečnike otvora koje treba izbušiti kako se ne bi desilo da se u toku obrade izbuše otvori na njemu (pojave kolizije između radnog predmeta, sa jedne strane, i elemenata pribora, sa druge strane). Peti I-profil se koristi za pridržavanje priteznih sklopova. Radni predmet se postavlja u pribor sa strane, pozicionira i steže. Izrađuje se prvi otvor. Potom se pribor pomera na radnom stolu i vrši se obrada drugog otvora. Radni predmet se otpušta, vadi iz pribora i stavlja se drugi predmet za obradu.

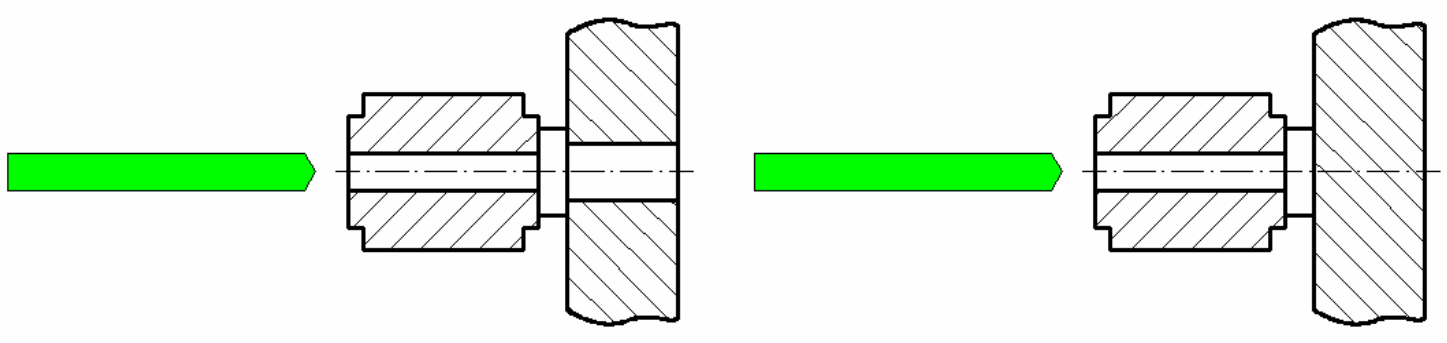

Slika 6.17. Ispravna i neispravna upotreba I-profila kao elementa tela pribora

Na slici 6.18. su prikazani karakteristični koraci u sintezi pribora za drugi radni predmet.

Radni predmet se pozicionira preko unutrašnje cilindrične površine upotrebom trna i preko ravne površine upotrebom čeonog naslona. Stezanje radnog predmeta se izvodi navojnim parom, preko navrtke (pokretnog elementa) i vijka (nepokretnog elementa) koji se nalazi na završetku cilindričnog trna. Izmenjiva vođica odgovarajućeg prečnika se postavlja u nosač vođice. Dovođenje radnog predmeta u potreban položaj za bušenje obezbeđuje se preko okretnog uređaja. Okretni uređaji omogućavaju okretanje radnog predmeta oko horizontalne ose, uz vršenje određene podele. Uređaji se sastoje iz okretne okrugle (podeone) ploče koja se obrće oko centralnog 
trna. Trn se nalazi na elementima tela, a smešten je u čauri. Element za podelu je izveden kao podeoni sklop sa čepom. Telo pribora se sastoji od dva profila, I i L profila, međusobno spojena vijcima i čivijama.

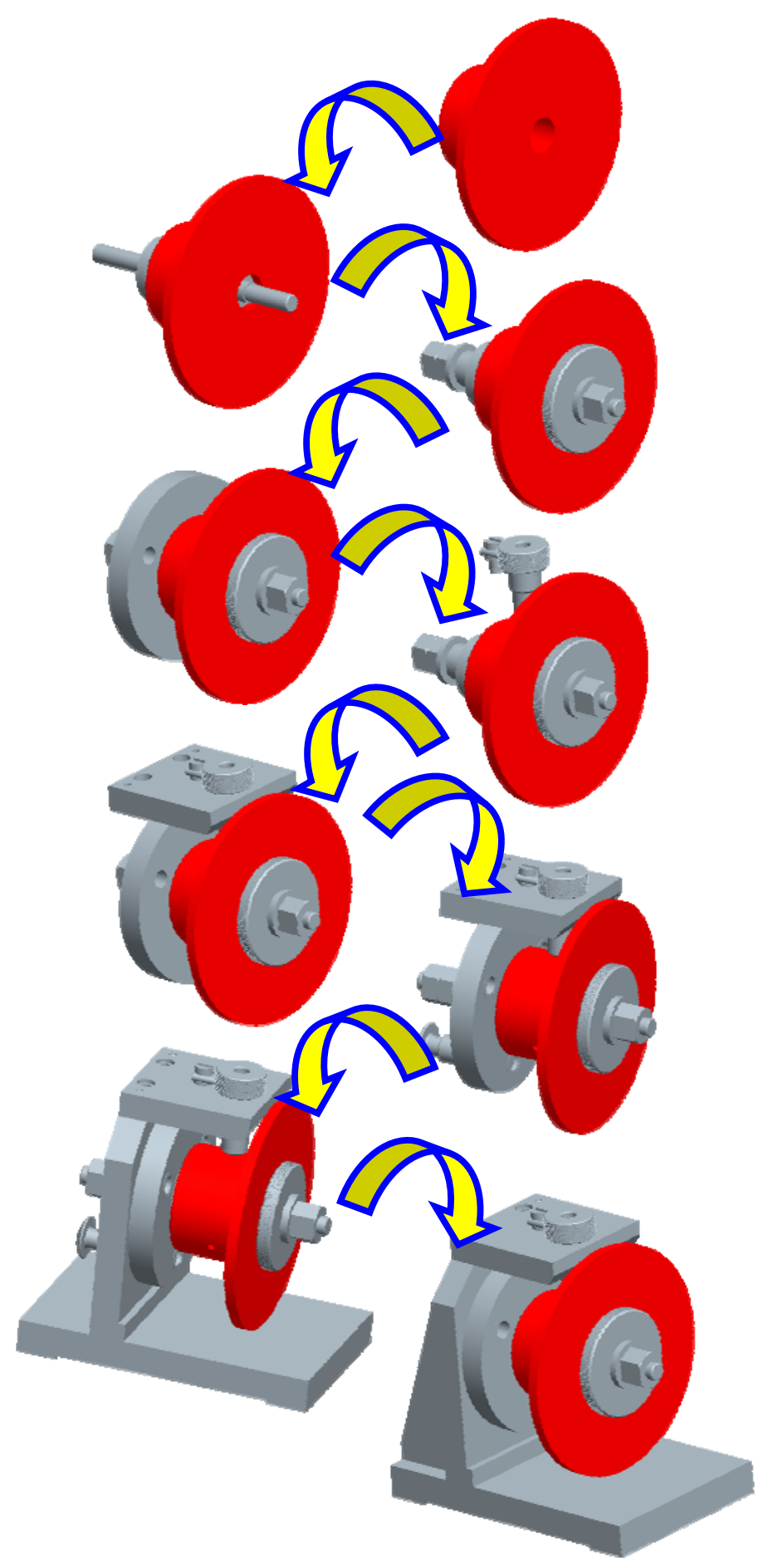

Slika 6.18. Karakteristični koraci u sastavljanju pribora 
Tačan položaj bušenja se obezbeđuje pomoću obrtne podeone ploče tako što se radni predmet zajedno sa podeonom pločom zarotira za potreban ugao neposredno pre izvršenja sledeće operacije obrade. Fiksiranje radnog predmeta u potrebnom položaju se obezbeđuje podeonim sklopom (slika 6.19).

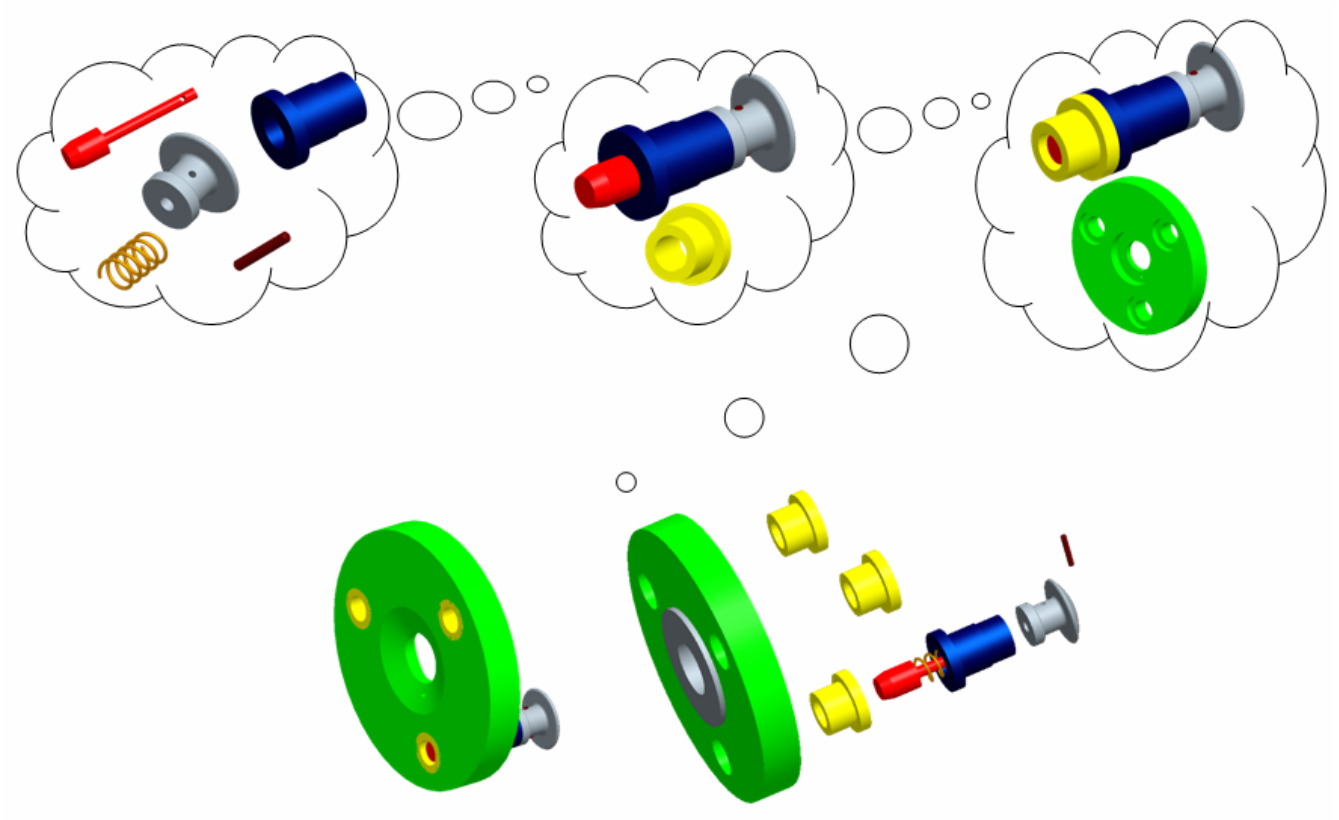

Slika. 6.19. Izvedba podeonog uređaja

$\mathrm{Na}$ cilindričnom trnu je potrebno izbušiti otvor prečnika nekoliko milimetara većeg u odnosu na prečnik otvora koji je potrebno izbušiti na definisanom rastojanju u odnosu na čeoni naslon kako se ne bi javila kolizija između elementa za pozicioniranje i alata za obradu rezanjem (slika 6.20).
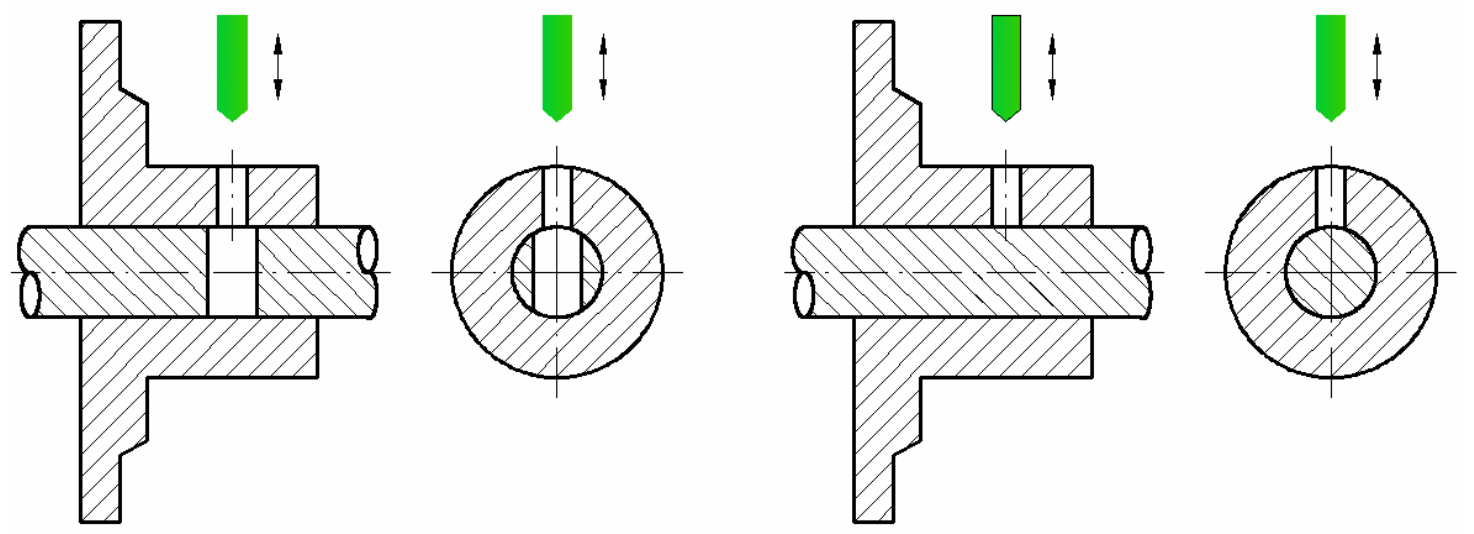

Slika 6.20. Ispravno i neispravno pozicioniranje radnog predmeta 
U odnosu na postojeću konstrukciju pribora (elemenata koje nudi programsko rešenje sistema) dodata su dva rebra za ojačanje - povećanje krutosti pribora.

Na slici 6.21. su prikazani karakteristični koraci u sintezi pribora za treći radni predmet.

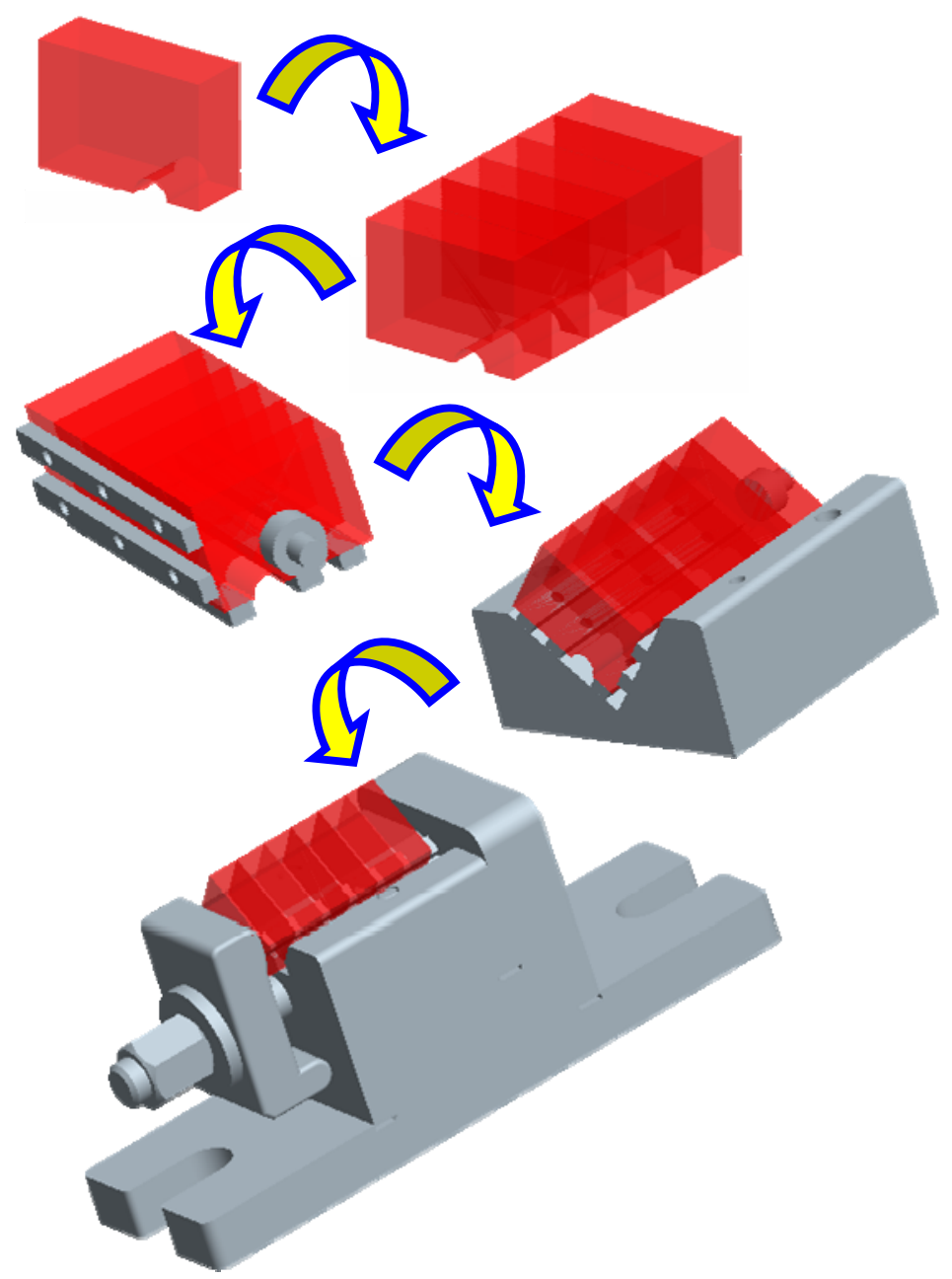

Slika 6.21. Karakteristični koraci u sastavljanju pribora

Pozicioniranje radnih predmeta se izvodi pomoću pet ravnih naslona i jednog okruglog naslona. Istovremeno se pozicionira šest radnih predmeta. Umesto obrtnog tela koje sugeriše sistem, u konstrukciju pribora umetnut je specijalni V-profil koji se čivijama i vijcima vezuje za L-profil postojeće konstrukcije pribora. Za V-profil se vezuju elementi za pozicioniranje izvedeni u obliku ravnih naslona. Stezanje radnih predmeta je redno uz pomoć složenog mehanizma sa stezanje, koji se sastoji od navrtke i šape. Stezanje se ostvaruje okretanjem navrtke ključem u odnosu na nepokretni vijak koji je prethodno uvrnut u $\mathrm{V}$-profil, a moment stezanja se prenosi preko šape na 
radne predmete. Svi elementi pribora su međusobno pozicionirani pomoću čivija i stegnuti adekvatnim vijcima. Pribor se u toku obrade fiksira preko ušica a uz pomoć vijka i navrtke za T-žlebove radnog stola mašine alatke. I-profil sa urezima predstavlja osnovni element tela pribora, a istovremeno i element za vezu sa radnim stolom glodalice. Korišćenjem vijčane veze pribor se preko ovog elementa (njegovih ureza) steže za radni sto mašine alatke. Izbor mesta za stezanje vrši se prema rasporedu žlebova na radnom stolu mašine alatke.

Na postojeću konstrukciju pribora dodat je sigurnosni element kako bi se obezbedio pravilan položaj radnog predmeta u priboru. Naime, moguće je da operater, pri postavljanju radnih predmeta u pribor, radni predmet postavi u pogrešan položaj što će prouzrokovati uklanjanje materijala sa pogrešne strane, a time će doći i do direktne pojave škarta (slika 6.22). Za izradu sigurnosnog elementa moguće je koristiti bilo koji postojeći element u proizvodnom sistemu. Ovaj element je potrebno fiksirati na pogodne elemente pribora odgovarajućim elementima za vezu. Posebno treba obratiti pažnju na njegove dimenzije kako ne bi došao u kontakt ni sa jednom površinom radnog predmeta, jer bi u tom slučaju preuzeo ulogu izabranih elemenata za pozicioniranje što bi takođe dovelo do neželjene netačnosti izrade (slika 6.23).

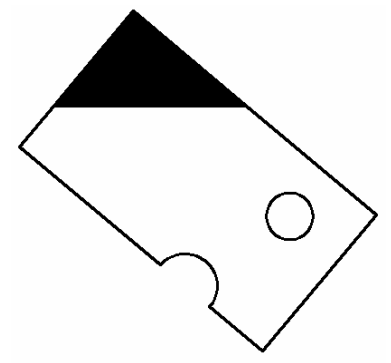

a)

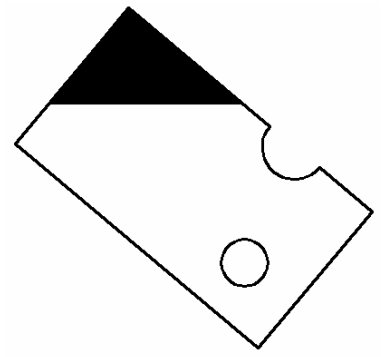

b)

Slika 6.22. Mogući položaji postavljanja radnog predmeta u priboru a) ispravan položaj; b) neispravan položaj
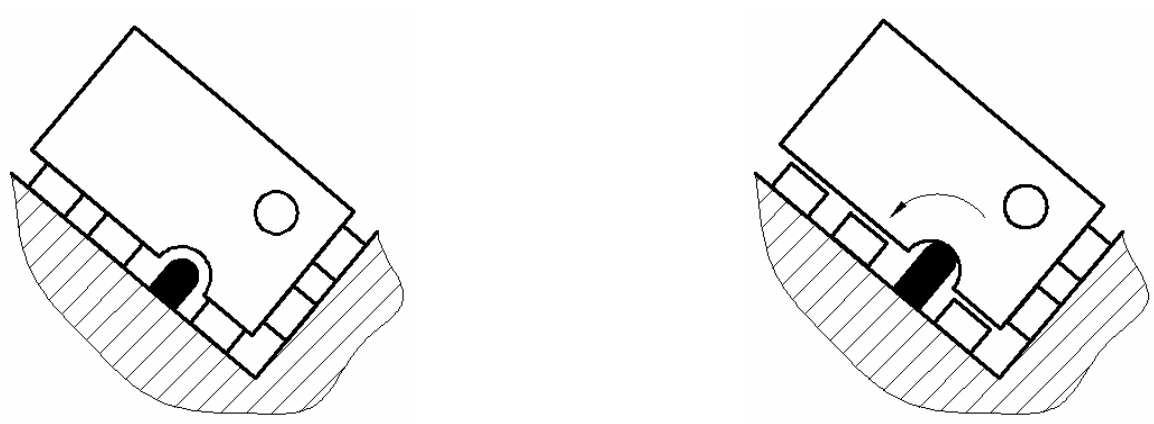

Slika 6.23. Upotreba sigurnosnog elementa

a) ispravna; b) neispravna. 
Na postojeće elemente (konstrukciju pribora) dodati su još i odstojnik (nadogradni element) i vijak (element za vezu). Odstojnik onemugućuje obrtanje šape kao sastavnog dela priteznog sklopa oko svoje ose (slika 6.24). Vijak se koristi za vezu odstojnika sa telom pribora.
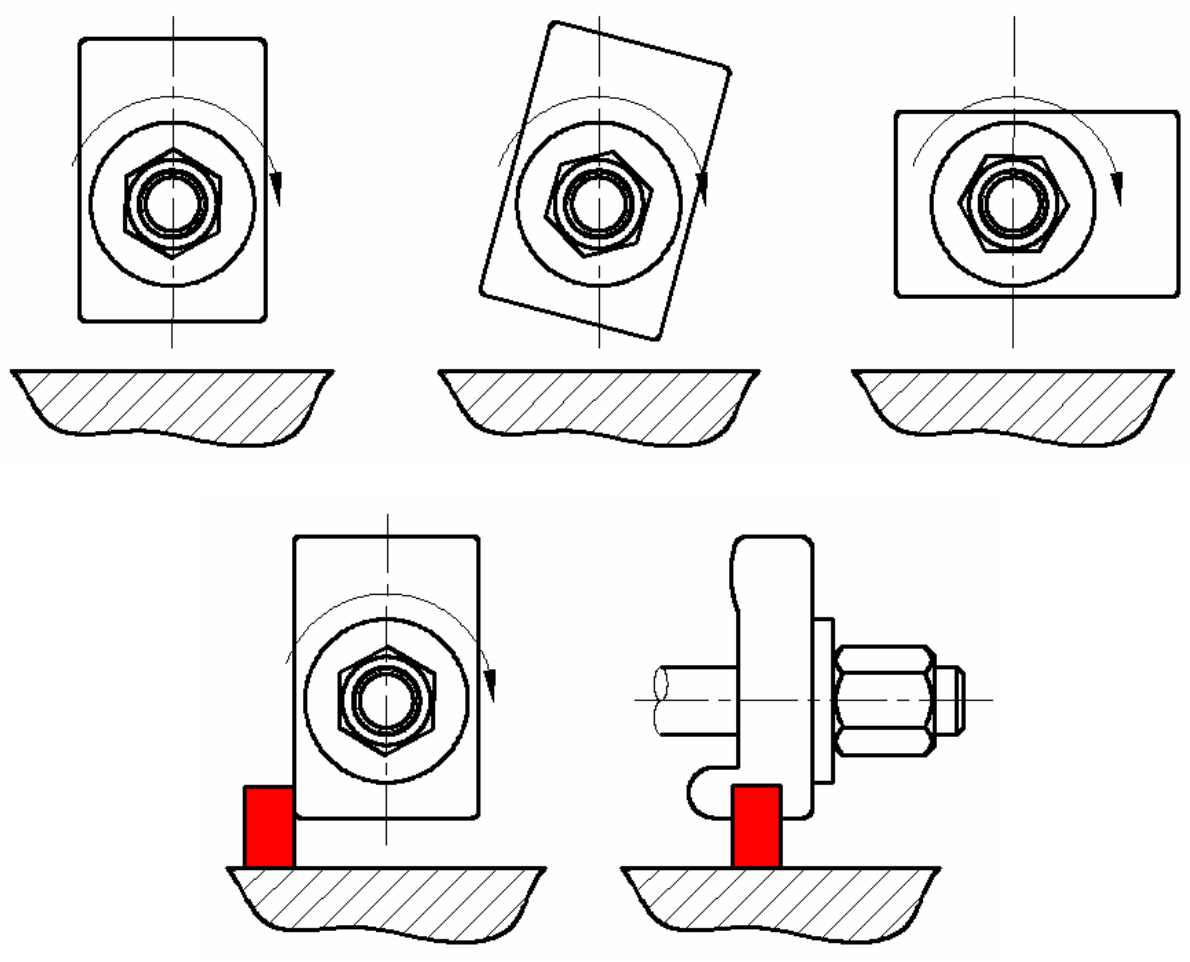

Slika 6.24. Obezbeđenje od obrtanja šape upotrebom odstojnika

Nakon što se izvrši sastavljanje pribora sprovodi se procedura analize konstrukcije u smislu detektovanja i otklanjanja potecijlanih kolizija. Pošto je utvrđeno da one ne postoje, na kraju je još potrebno formirati odgovarajuću tehničku dokumentaciju. Izlazni rezultati iz sistema za automatizovano projektovanje i optimizaciju konstrukcije pribora za prethodno opisane operacije obrade radnih predmeta prikazani su na slikama 6.25-6.27. 


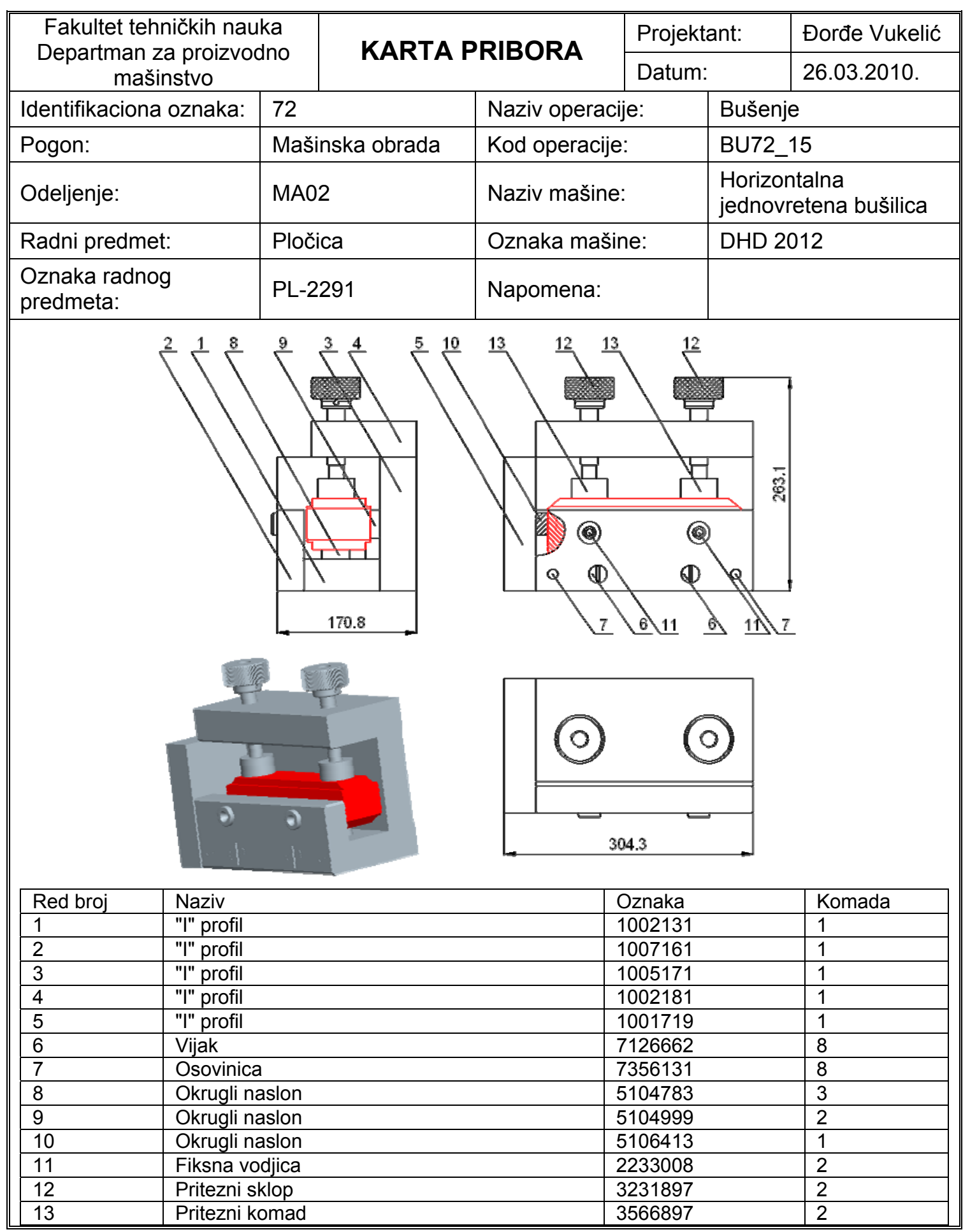

Slika 6.25. Izlazni rezultat iz sistema - karta pribora 


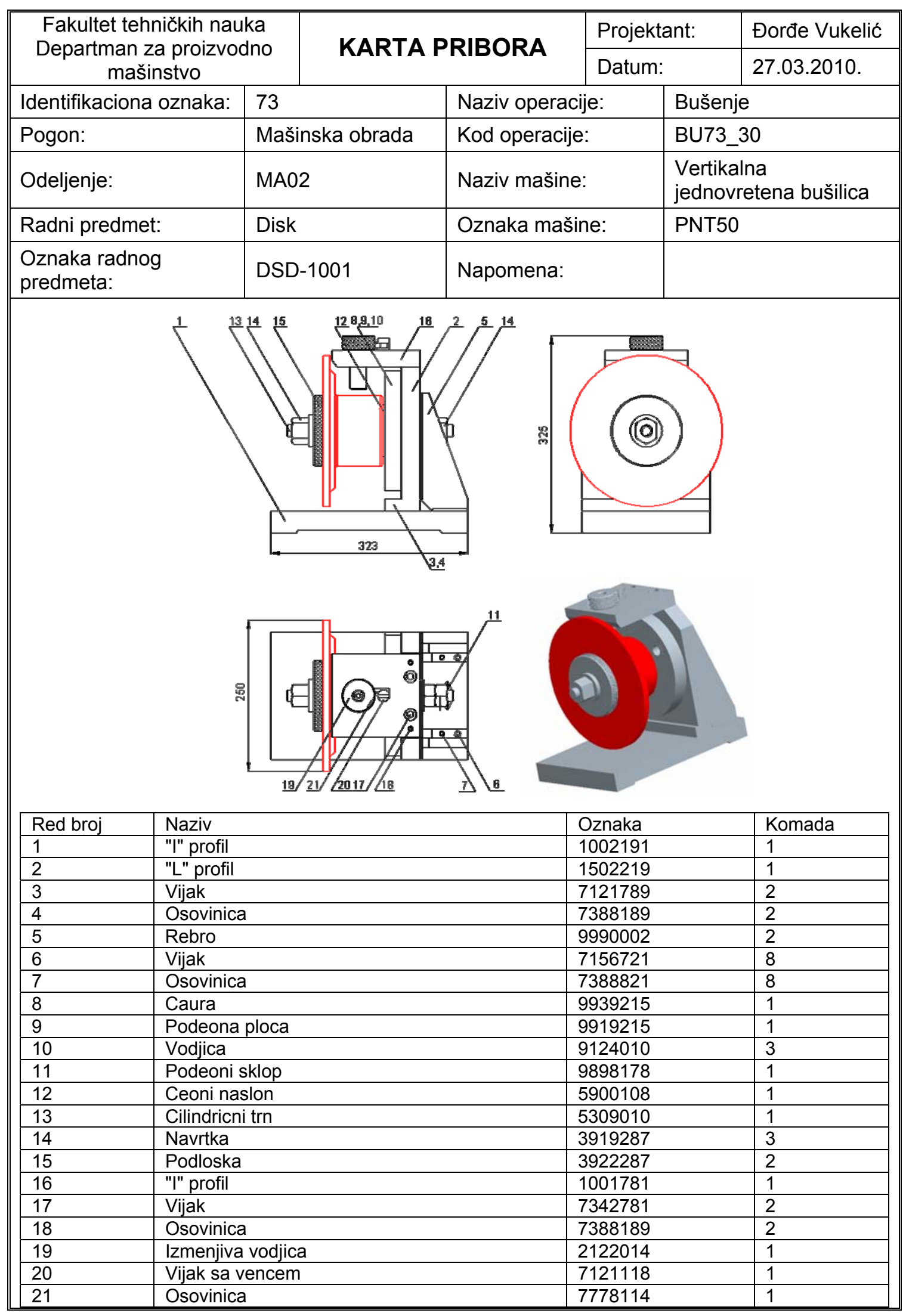

Slika 6.26. Izlazni rezultat iz sistema - karta pribora 


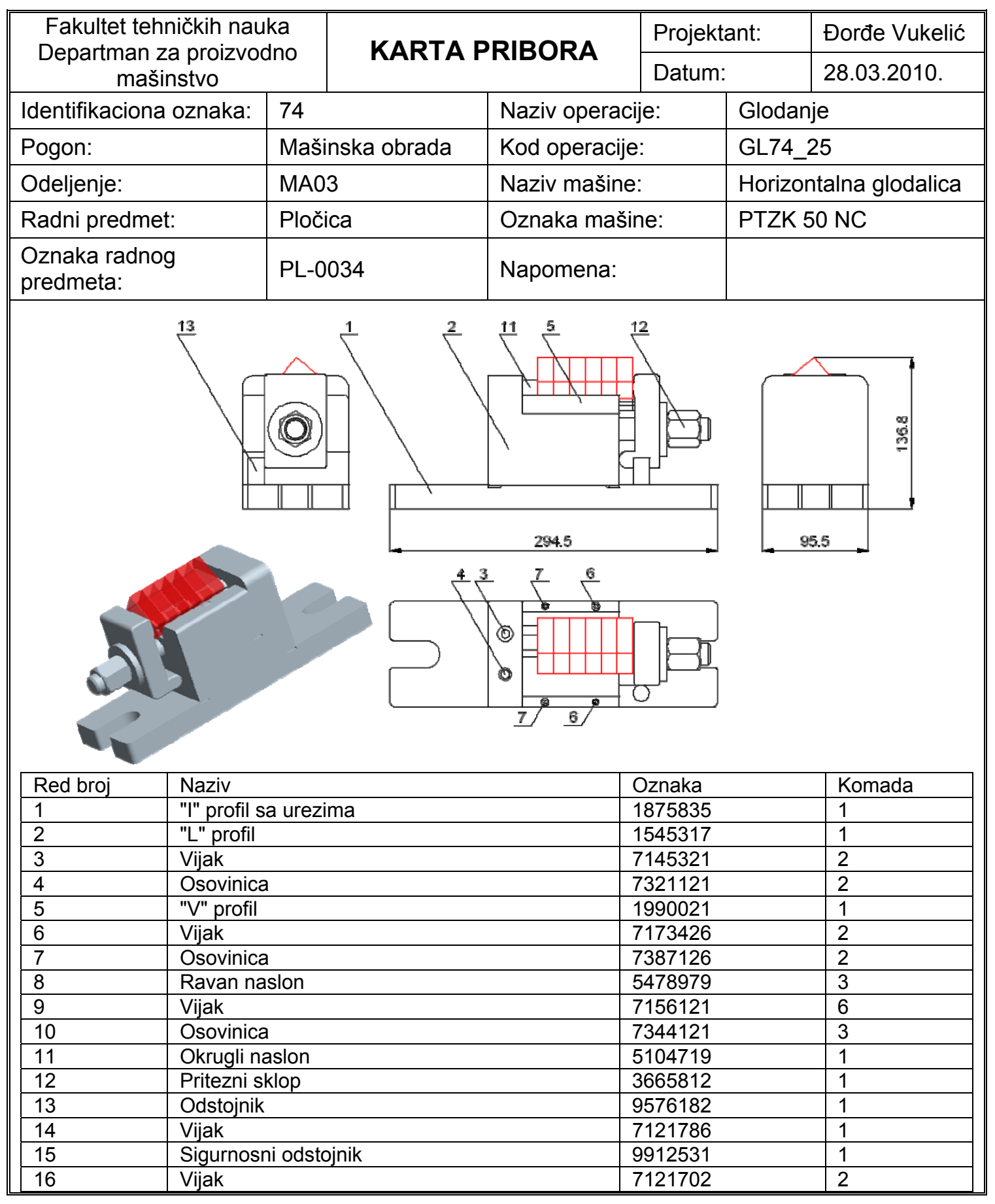

Slika 6.27. Izlazni rezultat iz sistema - karta pribora 


\section{7}

\section{ZAKLJUČNA RAZMATRANJA I PRAVCI BUDUĆIH ISTRAŽIVANJA}

Projektovanje pribora je složen proces koji, ukoliko se želi dobar rezultat, iziskuje od projektanta veliko znanje i iskustvo. Zbog toga je i automatizacija projektovanja pribora vrlo težak posao i jedno je od uskih grla u fleksibilnim proizvodnim sistemima.

Istraživanja prikazana u radu dala su doprinos teoriji i praksi u oblasti automatizacije projektovanja pribora. Karakteriše in originalan pristup $u$ pogledu primenjene metodologije za dolazak do postavljenog cilja, u postavljenoj koncepciji programskog sistema i u pogledu realizovanog programskog rešenja.

Istraživanja i razvoj pojedinih delova sistema obavljeni su u nekoliko faza. U prvoj razvojnoj fazi radilo se na sistematizaciji osnovnih podloga neophodnih za razvoj strukture sistema. Druga razvojna faza predstavlja nastavak $\mathrm{i}$ proširenje prethodnih istraživanja, karakterišu je dalji razvoj informacionih podloga za automatizovano projektovanje pribora, kao i postavljanje i razvoj osnove strukture sistema za automatizovano projektovanje i optimizaciju konstrukcije pribora. $U$ trećoj razvojnoj fazi objedinjena su prethodna istraživanja i razvijeno je programsko rešenje sistema.

$\mathrm{U}$ radu je predstavljen i verifikovan sistem za integralno projektovanje pribora koji obuhvata metode i tehnike za definisanje, vrednovanje i optimizaciju projektovane konstrukcije pribora. Sistem omogućava projektovanje konstrukcije pribora na osnovu geometrijskih karakteristika radnog predmeta, tolerancija tehnoloških mera i sila koje se javljaju u postupku mašinske obrade. Sistem takođe obezbeđuje optimizaciju konstrukcije pribora na osnovu rasporeda elemenata za pozicioniranje i stezanje. Sistem za projektovanje pribora može da generiše nekoliko rešenja koja su sortirana po 
određenim kriterijumima. Da bi se kvalitet projektovanog rešenja pribora mogao „izmeriti“, definisana su dva modela, jedan geometrijski i drugi kinetički, koji omogućavaju da se opišu relacije između radnog predmeta i pribora. Sistem integriše fazu projektovanja i fazu optimizacije konstrukcije pribora, čime se dobija jedan viši nivo u automatizovanom projektovanju pribora.

Rezultati sprovedenih istraživanja u okviru disertacije mogu se podeliti u dve celine.

Prvu celinu čine opsežna teorijska istraživanja koja se odnose na primenu analize i sinteze u proučavanju literaturnih informacija. Na bazi toga je izvršena sistematizacija relevantnih metoda i prilaza koji su do sada bili zastupljeni u procesu računarom podržanog projektovanja pribora. Posebna pažnja je posvećena analizi prilaza koji su bazirani na primeni veštačke inteligencije u procesu projektovanja pribora, a čija je primena u stalnoj ekspanziji. Na osnovu analize različitih prilaza u racionalizaciji i automatizaciji projektovanja pribora i kontakata sa naučnicima i ekspertima iz posmatrane oblasti, autor je definisao cilj rada i postavio odgovarajuće hipoteze.

Drugu celinu rada obuhvata sa jedne strane postavljanje modela sistema i razvoj softverskih rešenja modula u okviru integralnog sistema za automatizovano projektovanje i optimizaciju konstrukcije pribora, a sa druge strane, verifikaciju razvijenog modela i programskog sistema kroz računarsko-eksperimentalnu proveru na realnim primerima iz industrijske prakse.

Razvijena struktura sistema za automatizovano projektovanje pribora postavljena je na modularnom principu, uz formiranu bazu podataka, razvijene računarske programe i integrisane programske sisteme. Postavljena struktura sistema pretpostavlja sistematizaciju podloga za projektovanje pribora. Osnovne podloge su kriterijumi izbora elemenata i odgovarajuća logika odlučivanja pri projektovanju.

Kroz istraživanje su sistematizovane osnovne podloge za razvoj informacione baze za mnogo širi spektar funkcionalnih grupa elemenata pribora, a u vezi s tim, razvijen je i mnogo veći broj pouzdanih pravila izbora elemenata pribora. Pored ogovarajućih podloga za izbor elemenata za pozicioniranje i stezanje, karakterističnih za do sada razvijene sisteme u svetu, razvijene su i podloge za izbor: elemenata tela pribora, elemenata za vođenje alata, elemenata za podešavanje položaja alata, elemenata za vezu i velikim delom za nadogradne elemente.

U cilju provere postavljenog modela sistema projektovanja, razvijena su programska rešenja pojedinih modula sistema. Kako bi se potvrdila funkcionalnost razvijenog programskog rešenja za postavljeni model strukture 
sistema za automatizovano projektovanje pribora obavljena su detaljna testiranja za sve njegove module. $\mathrm{Na}$ taj način je potvrđena mogućnost praktične primene rezultata istraživanja.

Razvijeni sistem za automatizovano projektovanje i optimizaciju konstrukcije pribora omogućava da se, u okviru rada tehnološke pripreme proizvodnje, dođe do adekvatnih rešenja pribora u tekućoj proizvodnji i projektuje, za date uslove, odgovarajući pribor pri osvajanju novih proizvoda, odnosno delova, čime se utiče na podizanje tehnoekonomskih izlaznih efekata ukupnog procesa proizvodnje.

Razvijeni model bi se uz određene modifikacije mogao primeniti za projektovanje svih tipova pribora. Osim toga, model sistema predstavlja dovoljno uopštenu podlogu na kojoj je moguće graditi koncepciju za odgovarajuće projektovanje i kod drugih vrsta sklopova.

Rešenja do kojih se došlo u radu dovoljno su uopštena. Moguće ih je iskoristiti kao osnovu pri izgradnji užih sistema kao što su sistemi projektovanja pribora za neke operacije obrade, pribora za određene oblike radnih predmeta itd.

Za širu primenu razvijenog sistema za automatizovano projektovanje pribora i obezbeđenje praktičnih proizvodno-ekonomskih efekata, neophodne su dalje opsežne aktivnosti na izgradnji baze podataka, sa potrebnim brojem pouzdanih informacionih podloga, odnosno predloženih i proverenih sadržaja odgovarajućih datoteka. Ovo se naročito odnosi na razvoj dodatnih kriterijuma izbora sigurnosnih elemenata i elemenata za premošćavanje visinskih i dužinskih rastojanja.

Isto tako, neophodno je u okviru već razvijene strukture integralnog sistema usavršavati postojeće segmente sistema i raditi na njihovom uvođenju u praktičnu primenu kroz eventualno prilagođavanje konkretnom proizvodnom programu proizvodnje.

Sistem je dao dobre rezultate za prizmatične i rotacione radne predmete za operacije bušenja i glodanja. Ideja autora je bila da se sistem u prvoj fazi implementira za operacije obrade bušenja i glodanja. Ne bez razloga. Upravo je za ove operacije obrade najčešće potrebno izvesti proces projektovanja pribora. Za ostale operacije obrade (struganje, brušenje, itd.), većinu proizvodnih operacija je moguće sprovesti pomoću univerzalnih pribora koji se isporučuju zajedno sa mašinom alatkom. U prilog ovome idu i istraživanja prikazana na donjem grafiku. Na osnovu obimnih istraživanja objavljenih u literaturi [232] vidi se da se od ukupnog broja projektovanih pribora čak $84 \%$ 
odnosi na operacije bušenja i glodanja. U narednim fazama istraživanja sistem će biti razvijan i za ostale operacije obrade (struganje, brušenje, itd.)

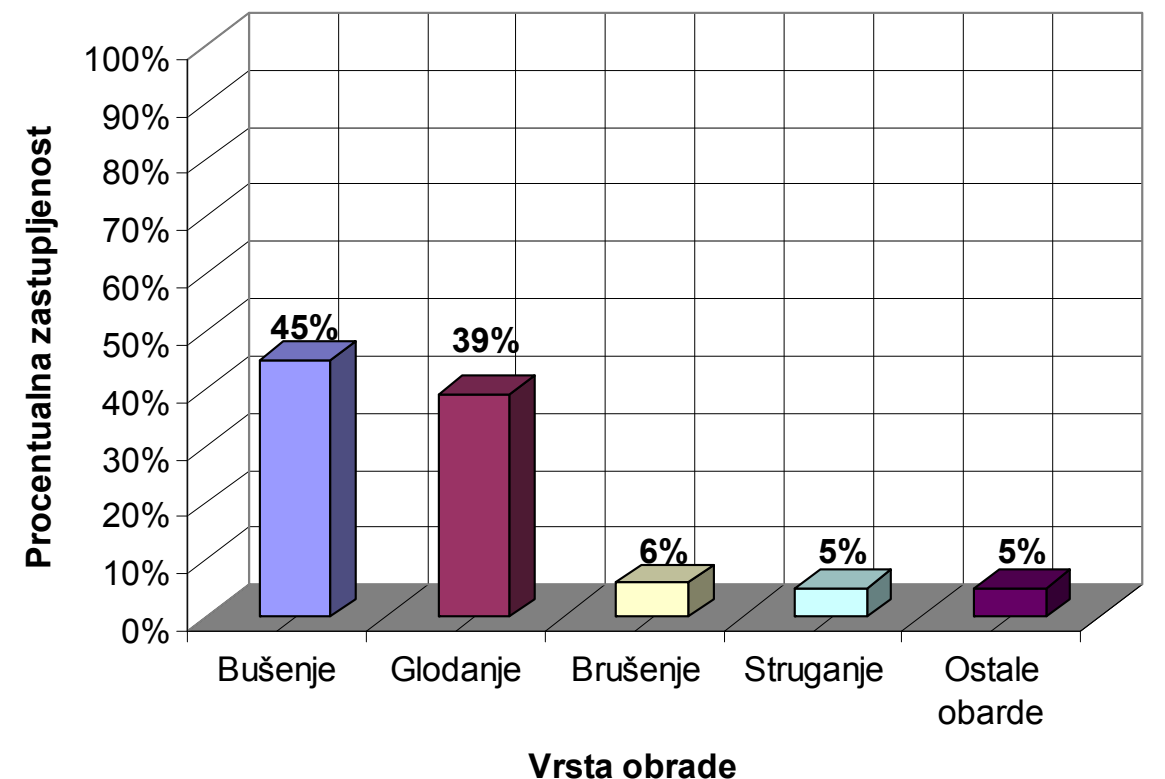

Slika 8.1. Procentualna zastupljenost projektovanih pribora u pojedinim operacijama obrade [232]

U zaključku ovog dela može se izdvojiti još nekoliko izazova u vezi sa projektovanjem pribora.

U okviru kinetičkog modela pribora, pretpostavlja se da je radni predmet kruto, a ne elastično telo. Drugim rečima, kinetički model trenutno ne uzima u obzir kontaktne deformacije radnog predmeta. Dinamika obrade i ergonomija pribora, takođe su validni zahtevi koje treba ispuniti prilikom projektovanja pribora. Umesto da prouči sve moguće zahteve, ova studija je usredsređena na izgradnju jednog opšteg okvira. Uz definisani okvir, u budućnosti će biti moguće identifikovati, proučiti i integrisati i druge oblasti u sistem.

Integracija CAFD sistema ostaje otvoreno pitanje, posebno u pogledu ispravke projektovanih rešenja koja ne zadovolje ispitivanja u fazi verifikacije. Ostaju otvorena i pitanja ko treba da koriguje pribor, kako to treba uraditi.

Stepen efikasnosti sistema mogao bi se povećati ako bi se sistem integralno povezao sa nekim od sistema za automatizovano projektovanje proizvoda i tehnoloških procesa njihove izrade. Izlazna informacija iz ovih sistema bi sadržala većinu podataka za definisanje ulaznih informacija kod automatizovanog projektovanja pribora. 
Sistemom nije u potpunosti obuhvaćena problematika upravljanja priborima. Postoje dodatna pitanja koja je potrebno rešiti, poput vremena potrebnog za montažu pribora, tačnosti montaže pribora, vremena potrebnog za postavljanje i vađenje radnog predmeta iz pribora, itd.

Budući pravac unapređenja sistema je i razvoj odgovarajućeg Web interfejsa uz pomoć kojeg bi se delu javnih podataka pristupalo putem globalne mreže. Uprkos očiglednim tehničkim i softverskim mogućnostima projektovanja pribora i dalje ostaje problem integracija računarom podržanog projektovanja proizvoda (CAD) u računarom podržanu proizvodnju (CAM). U skladu sa prirodnom potrebom za informacionim jedinstvom unutar proizvodnog sistema, postoji potreba da se informacioni sistemi za podršku projektovanju funkcionalno i sadržajno integrišu sa odgovarajućim sistemima drugih poslovnih funkcija u cilju povećanja efektivnosti sistema u celini. Proces projektovanja pribora nije u potpunosti implementiran sa ostalim procesima projektovanja. Uprkos istraživanjima kako da se automatizuje metodologija, nije se napredovalo u razvijanju metoda koje bi podržale projektovanje $u$ konkurentnom inženjerskom (CE) okruženju zasnovano na timskom radu. Budući pristupi u projektovanju pribora moraju biti fokusirani ne samo na povezanost CAD-a i CAM-a nego i, što je važnije, na traženje podrške multidisciplinarnih timova i konkurentnog inženjerskog pristupa.

Korišćenjem koncepta virtuelnog projektovanja pribora omogućio bi se razvoj ovakvih prilaza u kojim bi se projektovani pribor mogao proceniti, prostudirati, izmeniti i bolje razumeti od strane tima u virtuelnom okruženju.

U današnjem proizvodnom okruženju, planiranje i projektovanje se mogu fizički distribuirati širom planete, što povećava problem. Softverski alati i drugi resursi pristupačni su na različitim kompjuterskim platformama i implementirani su u raznim kompjuterskim jezicima koji ne moraju da budu kompatibilni. Zbog toga postoji potreba za razvojem novih metoda $u$ projektovanju pribora koji će novim pristupom omogućiti brzo projektovanje u realnom (dinamičkom) vremenu. U poslednje vreme mnogo pažnje se posvećuje standardizaciji u procesu integracije kako bi podaci u integrisanom sistemu bili uvek dostupni i konzistentni.

Iz priloženog se može videti da je ostalo još mnogo prostora za istraživanja u području projektovanja pribora. Može se očekivati da će novi pristupi biti zasnovani na nealgoritamskom programiranju i metodama veštačke inteligencije čime bi trebalo da se stvore uslovi za brzo unapređenje automatizacije projektovanja i proizvodnje u celini. Posebna pažnja mora se posvetiti tome da sistemi budu u što većoj meri integralni, univerzalni, konzistentni, fleksibilni, jednostavni, intuativni itd. 
Može se očekivati sve masovnija primena sličnih specijalizovanih rešenja namenjenih automatizaciji procesa projektovanja i proizvodnje određenih grupa proizvoda. Iznalaženje efikasnog rešenja univerzalnog karaktera, koje bi bilo primenjivo na širok spektar proizvodnih programa, još uvek je samo delimično rešiv zadatak.

Projektovanje pribora uz primenu računara predstavlja kompleksnu problematiku. Budući da računari u pogledu kapaciteta, memorije, brzine i kvaliteta rada značajno premašuju ljudske sposobnosti, automatizacija projektovanja pribora obezbeđuje bitno skraćenje procesa projektovanja, dobijanje kvalitetnijih rešenja, kao i smanjenje ukupnih troškova projektovanja. Sem toga, nivo zadovoljstva projektanta je viši, a radni napor u skoro svim fazama projektovanja manji.

lako se inteligentni sistemi stalno razvijaju, još uvek se ne može govoriti o generalnom rešenju inteligentnog projektovanja pribora. Razlog leži u činjenici da su ovakvi procesi vrlo kompleksni, da zavise od velikog broja faktora koje je potrebno uzeti u obzir pri projektovanju (a koje je u izvesnim slučajevima i nemoguće definisati). Činjenica je da inteligentni sistemi predstavljaju pokušaj simulacije rada ljudskog mozga, ali je to još uvek na nedovoljno visokom nivou da bi se moglo razmišljati o sistemu koji bi ulogu čoveka u projektovanju pribora u potpunosti zamenio. 


\section{LITERATURA}

[1]. Aamodt, A., Plaza, E.: Case-based reasoning: Foundational issues, methodological variations, and system approaches, Artificial Intelligence Communications, 1994, Vol. 7, No. 1, pp. 39-59, ISSN 0921-7126.

[2]. Amaral, N., Rencis, J. J., Rong, Y. M.: Development of a finite element analysis tool for fixture design integrity verification and optimisation. International Journal of Advanced Manufacturing Technology, 2005, Vol. 25. No. 5-6. pp. 409-419, ISSN 0268-3768.

[3]. Ameri, F., Summers, J. D.: An Ontology for Representation of Fixture Design Knowledge. Computer-Aided Design and Applications, 2008, Vol. 5. No. 5, pp. 601-611, ISSN 1686-4360.

[4]. Asada, H., By, A. B.: Kinematic Analysis of Workpart Fixturing for Flexible Assembly with Automatically Reconfigurable Fixtures. Journal of Robotics and Automation, 1985, Vol. 1, No. 2, pp.86-94, ISSN 0882$-4967$.

[5]. Aoyama, T., Kakinuma, Y.: Development of fixture devices for thin and compliant workpieces. CIRP Annals - Manufacturing Technology, 2005, Vol. 54, No. 1, pp. 325-328, ISSN 0007-8506.

[6]. Asante, J. N.: A small displacement torsor model for tolerance analysis in a workpiece-fixture assembly. Proceedings of the Institution of Mechanical Engineers - Part B - Journal of Engineering Manufacture, 2009, Vol. 223, No. 8, pp. 1005-1020, ISSN 0954-4054.

[7]. Asante, J. N.: A combined contact elasticity and finite element-based model for contact load and pressure distribution calculation in a frictional workpiece-fixture system. International Journal of Advanced Manufacturing Technology, 2008, Vol. 39, No. 5--6, pp. 78--88, ISSN 0268-3768. 
[8]. Babu, B. S., Valli, P. M., Kumar, A. V. V. A., Rao, D. N.: Automatic modular fixture generation in computer-aided process planning systems. Proceedings of the Institution of Mechanical Engineers - Part C - Journal of Mechanical Engineering Science, 2005, Vol. 219, No. 10 , pp. 1147-1152, ISSN 0954-4062.

[9]. Balasubramanian, S., Herrmann, J. W.: Using Neural Networks to Generate Design Similarity Measures. Technical Report TR 1999-38, Institute for Systems Research, University of Maryland, College Park, 1999, 17 p.

[10]. Bansal, S., Malik, P., Reddy, N. V., Saxena, A.: Modular fixture planning for minimum three-dimensional tolerances using a neutral part data exchange format. International Journal of Production Research, 2008, Vol. 46, No. 6, pp. 1455-1476, ISSN 0020-7543.

[11]. Bi, Z. M., Zhang, W. J.: Flexible fixture design and automation: Review, issues and future directions. International Journal of Production Research, 2001, Vol. 39, No. 13, pp. 2867-2894, ISSN 0020-7543.

[12]. Boyle, I. M., Rong, K., Brown, D. C.: Case-based reasoning in fixture design. Intelligent Manufacturing, 2004, Vol. 52, No 36, pp. 85-96, ISSN 0277-786X.

[13]. Boyle, I. M., Rong, K., Brown, D. C.: CAFixD: A case-based reasoning fixture design method - Framework and indexing mechanisms. Journal of Computing and Information Science in Engineering, 2006, Vol. 6, No. 1, pp. 40-48, ISSN 1530-9827.

[14]. Boerma, R. J., Kals, J. J. H.: FIXES a System for Automatic selection of Set-Ups and Design of Fixtures. CIRP Annals - Manufacturing Technology, 1988, Vol. 37, No. 1, pp. 443-446, ISSN 0007-8506.

[15]. Boerma, R. J., Kals, J. J. H.: Fixture Design with FIXTES, the Automatic Selection of Positioning, Clamping and Support Features fur Prismatis Parts. CIRP Annals - Manufacturing Technology, 1989, Vol. 38, No. 1, pp. 399-402, ISSN 0007-8506.

[16]. Bugtai, N., Young, R. I. M.: Information models in an integrated fixture decision support tool. Journal of Materials Processing Technology, 1998, Vol. 76, No. 1, pp. 29-35, ISSN 0924-0136.

[17]. Camelio, J., Hu, S. J., Zhong, W. P.: Diagnosis of multiple fixture faults in machining processes using designated component analysis. Journal of Manufacturing Systems, 2004, Vol. 23, No. 4, pp. 309-315, ISSN 0278-6125. 
[18]. Cai, W., Hu, S. J., Yuan, J. X.: A variational method of robust fixture configuration design for 3-D workpieces. Journal of Manufacturing Science and Engineering, 1997, Vol. 119, No. 4, pp. 593-602, ISSN 1087-1357.

[19]. Carlson, J. S.: Quadratic sensitivity analysis of fixtures and locating schemes for rigid parts. Journal of Manufacturing Science and Engineering, 2001, Vol. 123, No. 3, pp. 462-472, 1087-1357.

[20]. Cecil, J.: A clamping design approach for automated fixture design. International Journal of Advanced Manufacturing Technology, 2001, Vol. 18, No. 11, pp. 784--789, ISSN 0268-3768.

[21]. Cecil, J.: Computer aided fixture design: Using information intensive function models in the development of automated fixture design systems. Journal of Manufacturing Systems, 2002, Vol. 21, No. 1, pp. 58-71, ISSN 0278-6125.

[22]. Cecil, J.: Tamil: an integrated fixture design system for prismatic parts. International Journal of Computer Integrated Manufacturing, 2004, Vol. 17, No. 5, pp. 421-434, ISSN 0951-192X.

[23]. Chakraborty, D.,De Meter, E. C., Szuba, P. S.: Part location algorithms for an intelligent fixturing system Part 1: System description and algorithm development. Journal of Manufacturing Systems, 2001, Vol. 20, No. 2, pp. 124-134, ISSN 0278-6125.

[24]. Chakraborty, D., De Meter, E. C., Szuba, P. S.: Part location algorithms for an intelligent fixturing system Part 2: Algorithm testing and evaluation. Journal of Manufacturing Systems, 2001, Vol. 20, No. 2, pp. 135-148, ISSN 0278-6125.

[25]. Chakraborty, D., De Meter, E. C., Szuba, P. S.: Part location algorithms for an intelligent fixturing system. 29th North American Manufacturing Research Conference (NAMRC XXIX), Gainesville, USA, 2001, pp. 623-630, ISBN 0-87263-600-3.

[26]. Chang, H. C., Dong, L., Liu, F. X., Lu, W. F.: Indexing and retrieval in machining process planning using case-based reasoning, Artificial Intelligence in Engineering, 2000, Vol. 14, No. 1, pp. 1-13, ISSN 14740346.

[27]. Chen, G. F., Liu, W. J.: Variant fixture design with CBR. International Conference on Machine Learning and Cybernetics, Beijing, China, 2002, pp. 1465-1469, ISBN 0-7803-7508-4. 
[28]. Chen, G. F., Sun, Y. Z., Liu, W. J.: Feature and parametric-based fixture case modification. 5th International Conference on Machine Learning and Cybernetics, Dalian, China, 2006, pp. 1465-1470, ISBN 1-4244-0060-0.

[29]. Chen, W. F., Ni, L. J., Xue, J. B.: Deformation control through fixture layout design and clamping force optimization. International Journal of Advanced Manufacturing Technology, 2008, Vol. 38, No. 9-10, pp. 860-867, ISSN 0268-3768.

[30]. Chou, Y. C.: Automated planning and design of fixtures for complex parts. International Journal of Computer Applications in Technology, 1997, Vol. 10, No. 3-4, pp. 183-197, ISSN 0952-8091.

[31]. Čuš, F., Župerl, U.: A complete algorithm for optimization of modular fixtures. 3rd International Conference of the Danube Adria Association for Automation Manufacturing, Talin, Estonia, 2002, pp. 77-80, ISBN 9985-59-272-7.

[32]. Dachang, Z. H. U.: Sliding mode synchronous control for fixture clamps system driven by hydraulic servo systems. Proceedings of the Institution of Mechanical Engineers - Part C - Journal of Mechanical Engineering Science, 2007, Vol. 221, No. 9, pp. 1039-1045, ISSN 0954-4062.

[33]. Dai, J. R., Nee, A. Y. C., Fuh, J. Y. H., Kumar, A. S.: An approach to automating modular fixture design and assembly. Proceedings of the Institution of Mechanical Engineers - Part B - Journal of Engineering Manufacture, 1997, Vol. 211, No. 7, pp. 509-521, ISSN 0954-4054.

[34]. Darvishi, A. R., Gill, K. F.: Knowledge representation database for the development of a fixture design expert system. Proceedings of the Institution of Mechanical Engineers - Part B - Management and engineering manufacture, 1988, Vol. 202 No. 1, pp 37-49, ISSN 02637146.

[35]. Darvishi, A. R., Gill, K. F.: Expert system rules for fixture design. International Journal of Production Research, 1990, Vol. 28, No. 10, pp. 1901-1920, ISSN 0020-7543.

[36]. Deng, H.: Analysis and synthesis of fixturing dynamic stability in machining accounting for material removal effect, PhD Dissertation, Georgia Institute of Technology, Atlanta, Georgia, December 2006, 177 p. 
[37]. Deng, H. Y., Melkote, S. N.: Determination of minimum clamping forces for dynamically stable fixturing. International Journal of Machine Tools \& Manufacture, 2006, Vol. 46, No. 7-8, pp. 847-857, ISSN 0890-6955.

[38]. DeMeter, E. C.: Min-max load model for optimizing machine fixture performance. Journal of Engineering for Industry, 1995, Vol. 117, No. 2, pp. 183-186, ISSN 0022-0817.

[39]. DeMeter, E. C.: Fast Support Layout Optimization. International Journal of Machine Tools and Manufacture, 1998, Vol. 38, No. 10, pp. 12211239, ISSN 0890-6955.

[40]. DeMeter, E. C., Xi, W., Choudhuri, S., Vallapuzha, S., Trethewey, M.: A Model to Predict Minimum Required Clamp Pre-loads in Light of Fixture-Workpiece Compliance. International Journal of Machine Tools and Manufacture, 2001, Vol. 41, No. 7, pp. 1031-1054, ISSN 08906955.

[41]. Ding, D., Liu, Y. H., Wang, M. Y., Wang, S. G.: Automatic selection of fixturing surfaces and fixturing points for polyhedral workpieces. IEEE Transactions on Robotics and Automation, 2001, Vol. 17, No. 6, pp. 833-841, ISSN 1042-296X.

[42]. Ding, D., Liu, Y. H., Wang, M. Y.: Automatic selecting of fixturing polyhedral surfaces and fixturing points for workpieces. IEEE Conference on Intelligent Robots and Systems (IROS), Maui, USA, 2001, pp. 1147-1152, ISBN 0-7803-6612-3.

[43]. Dong, X., DeVries, W. R., Wozny, M. J.: Feature-based reasoning in fixture design. CIRP Annals - Manufacturing Technology, 1991, Vol. 40, No. 1, pp 111-114, ISSN 0007-8506.

[44]. Du, H., Lin, G. C. I.: Development of an automated flexible fixture for planar objects. Robotics and Computer-Integrated Manufacturing, 1998, Vol. 14, No. 3, pp. 173-183, ISSN 0736-5845.

[45]. Duan, G. L., Cai, J., Chen, X. Q. Yao, T., Xu, A. P.: Application of XML to the graphic exchange technology of the modular fixture. 7th WSEAS International Conference on Robotics, Control and Manufacturing Technology, 2007, Hangzhou, China, 2007, pp. 284-289, ISBN 978960-8457-67-6.

[46]. Estrems, M., Sanchez, H. T., Faura, F.: Influence of fixtures on dimensional accuracy in machining processes. International Journal of Advanced Manufacturing Technology, 2003, Vol. 21, No. 5, pp. 384390, ISSN 0268-3768. 
[47]. Fang, B., DeVor, R. E., Kapoor, S. G.: On the prediction of friction force at workpiece-fixture interface. 28th North American Manufacturing Research Conference (NAMRC XXVIII), Lexington, USA, 2000, pp. 209-214, ISBN 0-87263-518-X.

[48]. Fang, B., DeVor, R. E., Kapoor, S. G.: Influence of friction damping on workpiece-fixture system dynamics and machining stability. Journal of Manufacturing Science and Engineering, 2002, Vol. 124, No. 2, pp. 226-233, ISSN 1087-1357.

[49]. Fathianathan, M., Kumar, A. S., Nee, A. Y. C.: An adaptive machining fixture design system for automatically dealing with design changes. Journal of Computing and Information Science in Engineering, 2007, Vol. 7, No. 3, pp. 259-268, ISSN 1530-9827.

[50]. Gandhi, M. V., Thompson, B. S.: Automated Design of Modular Fixture for Flexible Manufacturing Systems. Journal of Manufacturing Systems, 1986, Vol. 5, No. 4, pp. 243-252, ISSN 0278-6125.

[51]. Gologlu, C.: Machine capability and fixturing constraints-imposed automatic machining set-ups generation. Journal of Materials Processing Technology, 2004, Vol. 148, No. 1, pp. 83-92, ISSN 09240136.

[52]. Grippo, P. M., Gandhi, M. V., Thompson, B. S.: The Computer-Aided Design of Modular Fixturing Systems. International Journal of Advanced Manufacturing Technology, 1987, Vol. 2, No. 2, pp. 75-88, ISSN 02683768.

[53]. Grippo, P. M., Thompson, B. S., Gandhi, M. V.: A review of flexible fixture systems for Computer Integrated Manufacturing, International Journal of Computer-Integrated Manufacturing, 1988, Vol. 1, No. 2, pp. 124-135, ISSN 0951-192X.

[54]. Gulesin, M.: Intermediate part modelling in a process planning and fixturing system. Robotics and Computer-Integrated Manufacturing, 1996, Vol. 12, No. 4, pp. 321-328, ISSN 0736-5845.

[55]. Hamedi, M.: On application of machine learning in fixture design and clamping optimization. IEEE International Conference on Mechatronics Automation, Niagara Falls, Canada, 2005, pp. 1562-1568, ISBN 07803-9044-X.

[56]. Hameed, R. A., Mannan, M. A., Nee, A. Y. C.: The cutting force measurement in a fixturing setup with instrumented locators. 
International Journal of Advanced Manufacturing Technology, 2004, Vol. 23, No. 11-12, pp. 783-793, ISSN 0268-3768.

[57]. Haymanali, R., De Meter, E. C., Trethewey, M. W.: Development of a compliance tester for assessing and reducing the static compliance of fixture-workpiece systems. Journal of Manufacturing Systems, 2000, Vol. 19, No. 2, pp. 108-120, ISSN 0278-6125.

[58]. Hodolič, J., Vukelić, Đ.: Pribori, Novi Sad, Fakultet tehničkih nauka, 2008, 250 p., ISBN 978-86-7892-121-6.

[59]. Hoffman. G. E.: Jig and fixture design, Delmar Learning Drafting, 2004, $369 \mathrm{p}$, ISBN 1-4018-1107-8.

[60]. Hou, J. L., Trappey, A. J. C.: A methodology for applying V-blocks and clamps to non-prismatic workpart fixtures. International Journal of Computer Applications in Technology, 1997, Vol. 10, No. 3-4, pp. 152169, ISSN 0952-8091; [metod pozicioniranja 3-2-1].

[61]. Hou, J. L., Trappey, A. J. C.: Computer-aided fixture design system for comprehensive modular fixtures. International Journal of Production Research, 2001, Vol. 39, No. 16, pp. 3703-3725, ISSN 0020-7543.

[62]. Hu, W., Rong, Y.: A fast interference checking algorithm for automated fixture design verification. International Journal of Advanced Manufacturing Technology, 2000, Vol. 16, No. 8, pp. 57-581, ISSN 0268-3768.

[63]. Hu, C. Q., Lin, Z. Q., Lai, X. M.: Concept design of checking fixture for auto-body parts based on neural networks. International Journal of Advanced Manufacturing Technology, 2006, Vol. 30, No. 5-6, pp. 574577, ISSN 0268-3768.

[64]. Hunter, R., Vizan, A., Perez, J., Rios, J.: Knowledge model as an integral way to reuse the knowledge for fixture design process. Journal of Materials Processing Technology, 2005, Vol. 164, pp. 1510-1518, ISSN 0924-0136

[65]. Hunter, R., Rios, J., Perez, J. M., Vizan, A.: A functional approach for the formalization of the fixture design process. International Journal of Machine Tools \& Manufacture, 2006, Vol. 46, No. 6, pp. 683-697, ISSN 0890-6955.

[66]. Hunter, R., Rios, J., Perez, J. M., Vizan, A.: Fixture knowledge model development and implementation based on a functional design approach. Robotics and Computer-Integrated Manufacturing, 2010, Vol. 26, No. 1, pp. 56-66, ISSN 0736-5845. 
[67]. Hurtado, J. F., Melkote, S. N.: A model for synthesis of the fixturing configuration in pin-array type flexible machining fixtures. International Journal of Machine Tools \& Manufacture, 2002, Vol. 42, No. 7, pp. 837849, ISSN 0890-6955.

[68]. Hurtado, J. F., Melkote, S. N.: Modeling and analysis of the effect of fixture-workpiece conformability on static stability. Journal of Manufacturing Science and Engineering, 2002, Vol. 124, No. 2, pp. 234-241, ISSN 1087-1357.

[69]. Inoue, T., Inasaki, I.: Feature-based fixture planning for workpieces. 10th International Conference on Precision Engineering (ICPE), Yokohama, Japan, 2001, pp. 892-896, ISBN 0-7923-7414-2.

[70]. Jeng, Y. C., Gill, K. F.: CAD-based approach to the design of fixtures for prismatic parts. Proceedings of the Institution of Mechanical Engineers Part B - Journal of Engineering Manufacture, 1997, Vol. 211, No. 7, pp. 523-538, ISSN 0954-4054.

[71]. Jiang, W., Wang, Z.,Cai, Y., Wang, K. K.: Computer-aided group fixture design. CIRP Annals - Manufacturing Technology, 1988, Vol 37. No 1, pp 145-148, ISSN 0007-8506.

[72]. Jin, J. H., Chen, Y.: Quality and reliability information integration for design evaluation of fixture system reliability. Quality And Reliability Engineering International, 2001, Vol. 17, No. 5, pp. 355-372, ISSN 0748-8017.

[73]. Joneja, A., Chang, T. C.: Setup and fixture planning in automated process planning systems. IIE Transactions, 1999, Vol. 31, No. 7, pp. 653-665, ISSN 0740-817X.

[74]. Joshi, P.: Jigs and Fixtures Design Manual, The McGraw Hill Componies, 2003, 237 p., ISBN 0-07-140556-9.

[75]. Jovičić, M., Dimitrijević-Marković, Lj.: Pomoćni pribori, Beograd, Mašinski fakultet, 1990, 314 p. ISBN 86-7083-124-4.

[76]. Kakish, J., Zhang, P. L., Zeid, I.: Towards the design and development of a knowledge-based universal modular jigs and fixtures system. Journal of Intelligent Manufacturing, 2000, Vol. 11, No. 4, pp. 381-401, ISSN 0956-5515.

[77]. Kang, Y., Rong, Y., Yang, J. C.: Computer-aided fixture design verification. Part 1. The framework and modelling. International Journal of Advanced Manufacturing Technology, 2003, Vol. 21, No. 10-11, pp. 827-835, ISSN 0268-3768. 
[78]. Kang, Y., Rong, Y., Yang, J. C.: Computer-aided fixture design verification. Part 2. Tolerance analysis. International Journal of Advanced Manufacturing Technology, 2003, Vol. 21, No. 10-11, pp. 836-841, ISSN 0268-3768.

[79]. Kang, Y., Rong, Y., Yang, J. C.: Computer-aided fixture design verification. Part 3. Stability analysis. International Journal of Advanced Manufacturing Technology, 2003, Vol. 21, No. 10-11, pp. 842-849, ISSN 0268-3768.

[80]. Kang, Y., Rong, Y., Yang, J., Ma, W.: Computer-aided fixture design verification. Assembly Automation, 2002, Vol. 22, No. 4, pp. 350-359, ISSN 0144-5154.

[81]. Kang, Y. G., Wang, Z., Li, R., Jiang, C.: A fixture design system for networked manufacturing. International Journal of Computer Integrated Manufacturing, 2007, Vol. 20, No. 2-3, pp. 143-159, ISSN 0951-192X.

[82]. Kaya, N., Ozturk, F.: The Application of Chip Removal and Frictional Contact Analysis for Workpiece-Fixture Layout Verification. International Journal of Advanced Manufacturing Technology, 2003, Vol. 21, No. 6, pp. 411-419, ISSN 0268-3768.

[83]. Klaerner, M., Leopold, J., Kroll, L.: Modelling and simulation of fixtures during grinding. Science in China Series E - Technological Sciences, 2009, Vol. 52, No. 7, pp. 1821-1829, ISSN 1006-9321.

[84]. Kumar, S. A., Nee A. Y. C., Prombanpong, S.: Expert fixture-design system for an automated manufacturing environment, Computer-Aided Design, 1992, Vol. 24, No. 6, pp. 317-326, ISSN 0010-4485.

[85]. Kumar, A. S., Nee, A. Y. C.: A framework for a variant fixture design system using case-based reasoning technique. Journal of Manufacturing Science and Engineering, 1995, Vol. 2, No. 1, pp. 763775 , ISSN 1087-1357

[86]. Kumar, A. S., Subramaniam, V., Teck, T. B.: Conceptual design of fixtures using machine learning techniques. International Journal of Advanced Manufacturing Technology, 2000, Vol. 16, No. 3, pp. 176181, ISSN 0268-3768; [okviri].

[87]. Kumar, A. S., Fuh, J. Y. H., Kow, T. S.: An automated design and assembly of interference-free modular fixture setup. Computer-Aided Design, 2000, Vol. 32, No. 10, pp. 583-596, ISSN 0010-4485.

[88]. Kumar, A. S., Bok, S. H., Kumar, R. K., Nee, A. Y. C.: The development of an Internet-enabled semi-automated fixture design 
system. IEEE/ASME International Conference on Advanced Intelligent Mechatronics (AIM 01), Como, Italy, 2001, pp. 195-200, ISBN 0-78036736-7.

[89]. Kim, G. J.: Case-based design for assembly. Computer Aided Design, 1997, Vol. 29, No. 7, pp. 497--506, ISSN 0010-4485.

[90]. Kow, T. S., Kumar, A. S., Fuh, J. Y. H.: An integrated approach to collision-free computer-aided modular fixture design. International Journal of Advanced Manufacturing Technology, 2000, Vol. 16, No. 4, pp. 233-242, ISSN 0268-3768.

[91]. Lee, E. C., Sarma, S. E.: On the development of a fully automated universal fixturing system for a machine tool. IEEE/ASME International Conference on Advanced Intelligent Mechatronics (AIM 01), Como, Italy, 2001, pp. 296-301, ISBN 0-7803-6736-7.

[92]. Lee, B. W., Saitou, K.: Integrated synthesis of assembly and fixture scheme for properly constrained assembly. IEEE Transactions on Automation Science and Engineering, 2005, Vol. 2, No. 3, pp. 250-261, ISSN 1545-5955.

[93]. Li, B., Melkote, S. N., Liang, S. Y.: Analysis of reactions and minimum clamping force for machining fixtures with large contact areas. International Journal of Advanced Manufacturing Technology, 2000, Vol. 16, No. 2, pp. 79-84, ISSN 0268-3768.

[94]. Li, B., Melkote, S. N.: Fixture clamping force optimisation and its impact on workpiece location accuracy. International Journal of Advanced Manufacturing Technology, 2001, Vol. 17, No. 2, pp. 104113, ISSN 0268-3768.

[95]. Li, B., Hu, Y., Tang, H., Yu, H. J., Hu, H.: A comparative study on quality design of fixture planning for sheet metal assembly. Journal of Engineering Design, 2008, Vol. 19, No. 1, pp. 1-13, ISSN 0954-4828.

[96]. Li, K. L., Liu, R., Bai, G. H., Zhang, P.: Development of an intelligent jig and fixture design system. 7th International Conference on Computer-Aided Industrial Design and Conceptual Design, Hangzhou, China, 2006, pp. 703-707, ISBN 978-1-4244-0683-8.

[97]. Li, W., Li, P. G., Rong, Y.: Case-based agile fixture design. Journal of Materials Processing Technology, 2002, Vol. 128, No. 1-3, pp. 7-18, ISSN 0924-0136.

[98]. Liao, Y. G., Hu, S. J.: An integrated model of a fixture-workpiece system for surface quality prediction. International Journal of Advanced 
Manufacturing Technology, 2001, Vol. 17, No. 11, pp. 810-818, ISSN 0268-3768.

[99]. Liqing F., Kumar, A. S.: XML-based Representation in a CBR System for Fixture Design, Computer-Aided Design \& Applications, 2005, Vol. 2, No. 1-4, pp 339-348, ISSN 1686-4360.

[100]. Lin, L., Zhang, Y. F., Nee, A. Y. C.: An integrated setup planning and fixture design system for prismatic parts. International Journal of Computer Applications in Technology, 1997, Vol. 10, No. 3-4, pp. 198212, ISSN 0952-8091.

[101]. Lin, Z. C., Huang, J. C.: The application of neural networks in fixture planning by pattern classification. Journal of Intelligent Manufacturing, 1997, Vol. 8, No. 4, pp. 307-322, ISSN 0956-5515.

[102]. Lin, Z. C., Huang, J. C.: The application of the simulated annealing method and heuristic algorithms in the selection of fixture elements. International Journal of Advanced Manufacturing Technology, 1997, Vol. 13, No. 3, pp. 191-205, ISSN 0268-3768.

[103]. Lin, Z. C., Huang, J. C.: The fixture planning of modular fixtures for measurement. IIE Transactions, 2000, Vol. 32, No. 4, pp. 345-359, ISSN 0740-817X.

[104]. Liu, S. G., Zheng, L., Zhang, Z. H., Wen, D. H.: Optimal fixture design in peripheral milling of thin-walled workpiece. International Journal of Advanced Manufacturing Technology, 2006, Vol. 28, No. 7-8, pp. 653658, ISSN 0268-3768.

[105]. Liu, S. G., Zheng, L., Zhang, Z. H. Li, Z. Z., Liu, D. C.: Optimization of the number and positions of fixture locators in the peripheral milling of a low-rigidity workpiece. International Journal of Advanced Manufacturing Technology, 2007, Vol. 33, No. 7-8, pp. 668-676, ISSN 0268-3768.

[106]. Liu, J. J. X., Strong, D. R.: Machining fixture verirification for linear fixture systems. International Journal of Production Research, 2002, Vol. 40, No. 14, pp. 3441-3459, ISSN 0020-7543.

[107]. Loose, J. P., Zhou, S.Y., Ceglarek, D.: Kinematic analysis of dimensional variation propagation for multistage machining processes with general fixture layouts. IEEE Transactions on Automation Science and Engineering, 2007, Vol. 4, No. 2, pp. 141-152, ISSN 1545-5955.

[108]. Ma, W., Lei, Z., Rong, Y.: FIX-DES: A computer-aided modular fixture configuration design system. International Journal of Advanced 
Manufacturing Technology, 1998, Vol. 14, No. 1, pp. 21-32, ISSN 0268-3768.

[109]. Ma, W., Li, J., Rong, Y.: Development of automated fixture planning systems. International Journal of Advanced Manufacturing Technology, 1999, Vol. 15, No. 3, pp. 171-181, ISSN 0268-3768.

[110]. Marin, R. A., Ferreira, P. M.: Kinematic analysis and synthesis of deterministic 3-2-1 locator schemes for machining fixtures. Journal of Manufacturing Science And Engineering, 2001, Vol. 123, No. 4, pp. 70719, ISSN 1087-1357.

[111]. Marin, R. A., Ferreira, P. M.: Optimal placement of fixture clamps: Maintaining form closure and independent regions of form closure. Journal of Manufacturing Science and Engineering, 2002, Vol. 124, No. 3, pp. 676-685. ISSN 1087-1357.

[112]. Marin, R. A., Ferreira, P. M.: Optimal placement of fixture clamps: Minimizing the maximum clamping forces. Journal of Manufacturing Science and Engineering, 2002, Vol. 124, No. 3, pp. 686-694, ISSN 1087-1357.

[113]. Markus, A., Markcusz, Z., Farkas, J., Fileman, J.: Fixture design using PROLOG: an expert system. Robotics and Computer Integrated Manufacturing, 1984, Vol. 1, No. 2, p. 167-172, ISSN 0736-5845.

[114]. Menassa, R. J., DeVries, W. R.: Locating point synthesis in fixture design. CIRP Annals - Manufacturing Technology, 1989, Vol. 38, No. 1, pp 165-169, ISSN 0007-8506.

[115]. Mervyn, F., Kumar, A. S., Bok, S. H., Nee, A. Y. C.: Development of an Internet-enabled interactive fixture design system. Computer-Aided Design, 2003, Vol. 35, No. 10, pp. 945-957, ISSN 0010-4485.

[116]. Mervyn, F., Kumar, A. S., Nee, A. Y. C.: Automated synthesis of modular fixture designs using an evolutionary search algorithm. International Journal of Production Research, 2005, Vol. 43, No. 23, pp. 5047-5070, ISSN 0020-7543.

[117]. Mervyn, F., Kumar, A. S., Nee, A. Y. C.: Fixture design information support for integrated design and manufacturing. International Journal of Production Research, 2006, Vol. 44, No. 11, pp. 2205--2219, ISSN 0020-7543.

[118]. Miller, A., Hannam, R .G.: Computer aided design using a knowledge base approach and its application to the design of jigs and fixtures. Proceedings of the Institution of Mechanical Engineers - Part B - 
Management and engineering manufacture, 1985, Vol. 199, No. 4, pp. 227-234, ISSN 0263-7146.

[119]. Nee, A. Y. C., Bhattacharyya, N., Poo, A. N.: Applyin in jigs and fixtures design. Robotics \& Computer-Integrated Manufacturing, 1987, Vol. 3. No. 2, pp. 195-201, ISSN 0736-5845.

[120]. Nee, A. Y. C., Kumar, A. S.: A Framework for an Object / Rule-Based Automated Fixture Design System. CIRP Annals - Manufacturing Technology, 1991, Vol.40, No. 1, pp. 147-152, ISSN 0007-8506.

[121]. Nee, A. Y. C., Kumar, A. S., Prombanpong, S., Puah, K. Y.: A feature based classification scheme for fixtures. CIRP Annals - Manufacturing Technology, 1992, Vol. 41, No. 1, pp. 189-192, ISSN 0007-8506.

[122]. Nee, A. Y. C., Whybrew, K. Kumar, S, A.: Advanced fixture design for FMS, Springer-Verlag, London, 1995, 204 p. ISBN 978-038719-908-5.

[123]. Nee, A. Y. C., Tao, J. Z., Kumar, S, A.: An Advanced Treatise on Fixture Design and Planning, World Scientific, 2004, 264 p., ISBN 981256-059-9

[124]. Ngoi, B. K. A., Tay, M. L., Wong, C. S.: Development of an automated fixture set-up system for inspection. International Journal of Advanced Manufacturing Technology, 1997, Vol. 13, No. 5, pp. 342-349, ISSN 0268-3768.

[125]. Nnaji, B. O., Lyu, P.: Rules for an expert fixturing system on a CAD screen using flexible fixture. Journal of Intelligent Manufacturing, 1990, Vol. 1, No. 1, pp. 31-48, ISSN 0956-5515.

[126]. Ozturk, F., Kaya, N., Alankus, O. B., Sevinc, S.: Machining features and algorithms for set-up planning and fixture design. Computer Integrated Manufacturing Systems, 1996, Vol. 9, No. 4, pp. 207-216, ISSN 0951-5240.

[127]. Ozturk, F.: The use of machining features in set-up planning and fixture design to interface $C A D$ to CAPP. International Journal of Vehicle Design, 1997, Vol. 18, No. 5, pp. 558-573, ISSN 0143-3369.

[128]. Padmanaban, K. P., Prabhaharan, G.: Dynamic analysis on optimal placement of fixturing elements using evolutionary techniques. International Journal of Production Research, 2008, Vol. 46, No. 15, pp. 4177-4214, ISSN 0020-7543.

[129]. Padmanaban, K. P., Arulshri, K. P., Prabhakaran, G.: Machining fixture layout design using ant colony algorithm based continuous 
optimization method. International Journal of Advanced Manufacturing Technology, 2009, Vol. 45, No. 9-10, pp. 922-934, ISSN 0268-3768.

[130]. Payne, J., Cariapa, V.: A fixture repeatability and reproducibility measure to predict the quality of machined parts. International Journal of Production Research, 2000, Vol. 38, No. 18, pp. 4763-4781, ISSN 0020-7543.

[131]. Pehlivan, S., Dempsey, C., Summers, J. D.: Information modeling for fixture design. ASME International Design Engineering Technical Conference/Computers and Information in Engineering Conference, Long Beach, USA, 2005, pp. 489-501, ISBN 0-7918-4741-1.

[132]. Pehlivan, S., Summers, J. D.: A review of computer-aided fixture design with respect to information support requirements. International Journal of Production Research, 2008, Vol. 46, No. 4, pp. 929-947, ISSN 0020-7543.

[133]. Pelinescu, D. M., Wang, M. Y.: Multi-objective optimal fixture layout design. Robotics and Computer-Integrated Manufacturing, 2002, Vol. 18, No. 5-6, pp. 365-372, ISSN 0736-5845.

[134]. Perremans, P.: Feature-based description of modular fixturing elements: The key to an expert system for the automatic design of the physical fixture. Advances in Engineering Software, 1996, Vol. 25, No. 1, pp. 19-27, ISSN 0965-9978.

[135]. Pham, D. T., Nategh, M. J. Sam Lazaro, A.: A knowledge-based jigand-fixture designers' assistant. The International Journal of Advanced Manufacturing Technology, 1989, Vol. 4, No. 1, pp. 26-45, ISSN 02683768.

[136]. Pham, D. T., Sam Lazaro, A.: Autofix - an expert CAD system for jigs and fixtures. International Journal of Machine Tools and Manufacture, 1990, Vol. 30, No. 3, pp. 403-411, ISSN 0890-6955.

[137]. Prabhaharan, G., Padmanaban, K. P., Krishnakumar, R.: Machining fixture layout optimization using FEM and evolutionary techniques. International Journal of Advanced Manufacturing Technology, 2007, Vol. 32, No. 11-12, pp. 1090--1103, ISSN 0268-3768.

[138]. Purushothaman, R.: Sensor Based Fixture Design and Verification, PhD Thesis, Worcester Polytechnic Institute, 2003, 82. p.

[139]. Qin, G. H., Zhang, W. H., Wan, M.: A mathematical approach to analysis and optimal design of a fixture locating scheme. International 
Journal of Advanced Manufacturing Technology, 2006, Vol. 29, No. 3-4, pp. 349-359, ISSN 0268-3768.

[140]. Qin, G. H., Zhang, W. H., Wan, M.: Analysis and optimal design of fixture clamping sequence. Journal of Manufacturing Science and Engineering, 2006, Vol. 128, No. 2, pp. 482-493, ISSN 1087-1357.

[141]. Qin, G. H., Zhang, W. H., Wu, Z. X., Wan, M.: Systematic modeling of workpiece-fixture geometric default and compliance for the prediction of workpiece machining error. Journal of Manufacturing Science and Engineering, 2007, Vol. 129, No. 4, pp. 789-801, ISSN 1087-1357.

[142]. Raghu, A., Melkote, S. N.: Analysis of the effects of fixture clamping sequence on part location errors. International Journal of Machine Tools \& Manufacture, 2004, Vol. 44, No. 4, pp. 373-382, ISSN 0890-6955.

[143]. Raghu, A., Melkote, S. N.: Modeling of workpiece location error due to fixture geometric error and fixture-workpiece compliance. Journal of Manufacturing Science and Engineering, 2005, Vol. 127, No. 1, pp. 75-83, ISSN 1087-1357.

[144]. Ramesh, R., Mannan, M. A., Poo, A. N.: Error compensation in machine tools - a review Part I: geometric, cutting-force induced and fixture-dependent errors. International Journal of Machine Tools \& Manufacture, 2000, Vol. 40, No. 9, pp. 1235-1256, ISSN 0890-6955.

[145]. Ratchev, S., Phuah, K., Liu, S.: FEA-based methodology for the prediction of part-fixture behaviour and its applications, Journal of Materials Processing Technology, 2007, Vol. 191, No. 1-3, pp. 260-264, ISSN 0924-0136.

[146]. Rodić, M.: Razvoj strukture integralnog sistema za automatizovano projektovanje pribora, Doktorska disertacija, Novi Sad, Fakultet tehničkih nauka, 1992, 169 p.

[147]. Rong, Y., Bai, Y.: Machining accuracy analysis for computer aided fixture design verification. Journal of Manufacturing Science And Engineering, 1996, Vol. 118, No. 3, pp. 289-300, ISSN 1087-1357.

[148]. Rong, Y. K., Bai, Y.: Automated generation of fixture configuration design. Journal of Manufacturing Science And Engineering, 1997, Vol. 119, No. 2, pp. 208-219, ISSN 1087-1357.

[149]. Rong, Y, Zhu, Y.: Computer-aided fixture design, Marcel Dekker, New York, 1999, 478 p. ISBN 978-082479-961-8 
[150]. Rong, Y., Hou, Z., Huang, S.: Advanced computer-aided fixture design, Academic Press, 2005, 424 p. ISBN 0-12-594751-8.

[151]. Rong, Y., et. al.: Development of an Internet based Technique and System for Monitoring and Control of Manufacturing Equipment, Federal Funding Projects, Computer-aided Manufacturing Laboratory, Department of Mechanical Engineering, Worcester Polytechnic Institute, Worcester, http://www.wpi.edu/, 2003-2007.

[152]. Rosenman, M.: Case-based evolutionary design. Artificial Intelligence for Engineering Design, Analysis and Manufacturing, 2000, Vol. 14, No. 1, pp 17-29, ISSN:0890-0604.

[153]. Roy, U., Liao, J. M.: Neural network model for selecting machining parameters in fixture design, Integrated Computer-Aided Engineering, 1996, Vol. 3, No. 3, pp. 149-157, ISSN:1069-2509

[154]. Roy, U., Liao, L. M., Sun, P. L., Fields, M. C.: Fixture design synthesis for a flexible manufacturing system. Integrated Computer-Aided Engineering, 1997, Vol. 4, No. 2, pp. 101-113, ISSN 1069-2509.

[155]. Roy, U., Liao, J. M.: Application of a blackboard framework to a cooperative fixture design system. Computers in Industry, 1998, Vol. 37, No. 1, pp. 67-81, 0166-3615.

[156]. Roy, U., Liao, J. M.: Fixturing analysis for stability consideration in an automated fixture design system. Journal of Manufacturing Science and Engineering, 2002, Vol. 124, No. 1, pp. 98-104, ISSN 1087-1357.

[157]. Sanchez, H. T., Estrems, M., Faura, F.: Determination of key workpiece product characteristics in a machining fixture using uncertainty analysis and loss cost function implementation. International Journal of Advanced Manufacturing Technology, 2009, Vol. 41, No. 5-6, pp. 452-460, ISSN 0268-3768.

[158]. Sangnui, S., Peters, F.: The impact of surface errors on the location and orientation of a cylindrical workpiece in a fixture. Journal of Manufacturing Science and Engineering, 2001, Vol. 123, No. 2, pp. 325-330, ISSN 1087-1357.

[159]. Satyanarayana, S., Melkote, S. N.: Finite element modeling of fixtureworkpiece contacts: single contact modeling and experimental verification. International Journal of Machine Tools \& Manufacture, 2004, Vol. 44, No. 9, pp. 903-913, ISSN 0890-6955. 
[160]. Sayeed, Q. A., De Meter, E. C.: Mixed-integer programming model for fixture layout optimization. Journal of Manufacturing Science and Engineering, 1999, Vol. 121, No. 4, pp. 701-708, ISSN 1087-1357.

[161]. Segal, L, Romanescu, C., Gojinetchi, N.: Methodologies for automated design of modular fixtures, International Conference on Manufacturing Systems 2001, Yassy, Romania, pp. 151-156.

[162]. Segal, L, Romanescu, C., Gojinetchi, N.: Application of modular fixturing for FMS, International Conference on Manufacturing Systems 2001, Yassy, Romania, pp. 157-162.

[163]. Shen, C. H., Lin, Y. T., Agapiou, J. S., Jones, G. L., Kramarczyk, M. A., Bandyopadhyay, P.: An innovative reconfigurable and totally automated fixture system for agile machining applications. 31st North American Manufacturing Research Conference (NAMRC), Hamilton, Canada, 2003, pp. 395-402, ISBN 0-87263-651-8.

[164]. Shirinzadeh, B.: Strategies for planning and implementation of flexible fixturing systems in a computer integrated manufacturing environment. Computers in Industry, 1996, Vol. 30, No. 3, pp. 175-183, ISSN 01663615.

[165]. Shirinzadeh, B.: Flexible fixturing for workpiece positioning and constraining. Assembly Automation, 2002, Vol. 22, No. 2, pp. 112-120, ISSN 0144-5154.

[166]. Siebenaler, S. P., Melkote, S. N.: Prediction of workpiece deformation in a fixture system using the finite element method. International Journal of Machine Tools \& Manufacture, 2006, Vol. 46, No. 1, pp. 51-58, ISSN 0890-6955.

[167]. Sinreich, D., Nelkenbaum, B. D.: Determining production sequences for single-stage multifunctional machining systems based on the tradeoff between fixture cost, re-fixturing and tool replenishment. IIE Transactions, 2006, Vol. 38, No. 10, pp. 813-828, ISSN 0740-817X.

[168]. Song, H., Rong, Y.: Locating completeness evaluation and revision in fixture plan. Robotics and Computer-Integrated Manufacturing, 2005, Vol. 21, No. 4-5, pp. 368-378, ISSN 0736-5845.

[169]. Subramaniam, V., Kumar, A. S., Seow, K. C.: A multi-agent approach to fixture design. Journal of Intelligent Manufacturing, 2001, Vol. 12, No. 1, pp. 31-42, ISSN 0956-5515. 
[170]. Subrahmanyam, S. R.: Fixturing features selection in feature-based systems. Computers in Industry, 2002, Vol. 48, No. 2, pp. 99-108, ISSN 0166-3615.

[171]. Subrahmanyam, S. R.: A method for generation of machining and fixturing features from design features, Computers in Industry, 2002, Vol. 47, No. 3, pp. 269-287, ISSN 0166-3615.

[172]. Sun, S. H., Chen, J. L.: An index system for modular fixture design: Applied to case-based reasoning. International Journal of Production Research, 1996, Vol. 34, No. 12, pp. 3487-3497, ISSN 0020-7543.

[173]. Sun, S. H., Chen, J. H. L.: A fixture design system using case-based reasoning. Engineering Applications of Artificial Intelligence, 1996, Vol. 9, No. 5, pp. 533-540, ISSN 0952-1976.

[174]. Sun, S. H., Chen, J. L.: Knowledge representation and reasoning methodology based on CBR algorithm for modular fixture design. Journal of The Chinese Society of Mechanical Engineers, 2007, Vol. 28, No. 6, pp. 593-603, ISSN 0257-9731.

[175]. Stampfer, M.: Automated setup and fixture planning system for boxshaped parts. International Journal of Advanced Manufacturing Technology, 2009, Vol. 45, No. 5-6, pp. 540-552, ISSN 0268-3768.

[176]. Šolaja, V.: Pomoćni pribori, Mašinski fakultet, Beograd, 1980, 142 p.

[177]. Tan, E. Y. T., Kumar, A. S., Fuh, J. Y. H., Nee, A. Y. C.: Modeling, analysis, and verification of optimal fixturing design. IEEE Transactions on Automation Science and Engineering, 2004, Vol. 1, No. 2, pp. 121-132, ISSN 1545-5955.

[178]. Tadić, B.: Specijalni stezni pribori, Kragujevac, Mašinski fakultet, 2002, 153 p., ISBN 86-80581-49-6.

[179]. Tadić, B.: Obradni procesi i specijalne mašine i uređaji, Kragujevac, Mašinski fakultet, 2006, 193 p., ISBN 86-80581-97-6.

[180]. Tanović, Lj., Jovičić, M.: Alati i pribori - projektovanje, proračuni $i$ konstrukcije pomoćnih pribora, Beograd, Mašinski fakultet, 2005, 202 p. ISBN 86-7083-516-9.

[181]. Todić, V.: Projektovanje tehnoloških procesa, Novi Sad, Fakultet tehničkih nauka, 2004, 361 p., ISBN 86-80249-93-9.

[182]. Tseng, Y. J.: Feature-based fixturing analysis for machining parts represented with multiple sets of features. International Journal of 
Production Research, 1998, Vol. 36, No. 10, pp. 2743-2770, ISSN 0020-7543.

[183]. Tseng, Y. J., Liu, C. C.: Concurrent analysis of machining sequences and fixturing set-ups for minimizing set-up changes for machining millturn parts. International Journal of Production Research, 2001, Vol. 39, No. 18, pp. 4197-4214, ISSN 0020-7543.

[184]. Tzen, J. J., Jeng, S. L., Cheing, W. H.: Analysis of two-dimensional fixture clamping with friction. JSME International Journal Series C Mechanical Systems Machine Elements and Manufacturing, 1999, Vol. 42, No. 2, pp. 451-460, ISSN 1340-8062.

[185]. Vallapuzha, S.,De Meter, E. C., Shabbir, C.,Khetan, R. P.: An investigation of the effectiveness of fixture layout optimization methods. International Journal of Machine Tools \& Manufacture, 2002, Vol. 42, No. 2, pp. 251-263, ISSN 0890-6955.

[186]. Vukelić, Đ., Hodolič, J.: System for computer aided modular fixtures design, The Journal of Manufacturing Engineering, 2006, Vol. 2, No. 5, pp. 35-42, ISSN 1335-7972.

[187]. Vukelić, Đ., Hodolič, J., Križan, P.: Modular fixtures database. Journal of Manufacturing Engineering, 2008, Vol. 7, No. 2, pp. 30-33, ISSN 1335-7972.

[188]. Vukelić, Đ., Hodolič, J., Agarski, B.: Handling automation of fixture and fixture elements in flexible technological structures. Journal of Manufacturing Engineering, 2008, Vol. 7, No. 4, pp. 86-90, ISSN 13357972.

[189]. Vukelić, Đ., Hodolič, J.: Development of a system for machining fixture design using case-based reasoning. Journal Research and Desing in Commerce \& Industry, 2008, Vol. 22, No. 6, pp. 39-48, ISSN 14514117.

[190]. Vukelić, Đ., Hodolič, J.: Information system for fixture design. Journal of Acta Mechanica Slovaca, 2008, Vol. 12, No. 4, pp. 103-114, ISSN 1335-2393.

[191]. Vukelić, Đ., Hodolič, J., Onderova, I., Krizan, P., Agarski, B.: An expert system for fixture design. Journal ERIN, 2008, Vol. 1, No. 1, pp. 21-26, ISSN 1337-9089.

[192]. Vukelić, Đ., Hodolič, J., Križan, P.: A model of integral system for fixture design. 12th International Scientific Conference Mechanical Engineering, 2008, pp. CD ROM, ISBN 978-80-227-2987-1. 
[193]. Vukelić, Đ., Župerl, U., Hodolič, J., Križan, P.: An analysis of possible aplication of RFID technology in machining fixture assembly/disassembly process. Journal Research and Desing in Commerce \& Industry, 2009, Vol. 7, No. 23-24, pp. 27-34, ISSN 14514117.

[194]. Vukelić, Đ., Hodolič, J.: Machining fixture design via expert system. Machine design, 2009, Vol. 1, No. 1., pp. 17-20, ISSN 1821-1259.

[195]. Vukelić, Đ, Župerl, U., Hodolič, J.: Complex system for fixture selection, modification, and design. The International Journal of Advanced Manufacturing Technology, 2009, Vol. 45, No. 7-8, pp. 731-748, ISSN 0268-3768.

[196]. Vukelić, Đ., Hodolič, J., Križan, P.: Handling of fixtures and fixture elements in flexible technological structures. 9. International conference on accomplishments in electrical and mechanical engineering and information technology, 2009, pp. 261-266, ISBN 978-99938-39-23-1.

[197]. Vukelić, Đ., Tadić, B., Hodolič, J., Matin, I., Križan, P.: Development a database of modular fixtures. 10th International Scientific Conference on Flexibile Technologies MMA, 2009, pp. 117-120, ISBN 978-867892-223-7.

[198]. Vukelić, Đ., Tadić, B., Hodolič, J.: Stanje i tendencije razvoja računarom podržanog projektovanja pribora u mašinskoj obradi rezanjem, Tehnika (Mašinstvo), 2009, Vol. 58, No. 2, pp. 1-11, ISSN 0040-2176.

[199]. Vukelić, Đ., Tadić, B., Hodolič, J., Križan, P., Simeunović, N.: Development of an inteligent system for fixture design using casebased reasoning (CBR) technique. Journal of Manufacturing Engineering, 2009, Vol. 8, No. 4, pp. 8-11, ISSN 1335-7972.

[200]. Walczyk, D. F., Longtin, R. S.: Fixturing of compliant parts using a matrix of reconfigurable pins. Journal of Manufacturing Science and Engineering, 2000, Vol. 122, No. 4, pp. 766-772, ISSN 1087-1357.

[201]. Wallack, A. S., Canny, J. F.: Planning for modular and hybrid fixtures. Algorithmica, 1997, Vol. 19, No. 1-2, pp. 40-60, ISSN 0178-4617.

[202]. Wang, C. Y., Inasaki, I.: Knowledge in the domain of feature-based fixturing planning. JSME International Journal - Series C - Mechanical Systems Machine Elements and Manufacturing, 1999, Vol. 42, No. 4, pp. 1085-1092, ISSN 1340-8062. 
[203]. Wang, Y. Z., Jiao, L., Sun, H. F.: An fixture design information model for integrated environment. 5th International Conference on Progress of Machining Technology (ICPMT 2000), Beijing, China, 2000, pp. 837-841, ISBN 7-80134-714-5.

[204]. Wang, M. Y.: An optimum design for 3-D fixture synthesis in a point set domain. IEEE Transactions on Robotics and Automation, 2000, Vol. 16, No. 6, pp. 839-846, ISSN 1042-296X.

[205]. Wang, Y. F., Wong, Y. S., Fuh, J. Y. H.: Off-line modelling and planning of optimal clamping forces for an intelligent fixturing system. International Journal of Machine Tools \& Manufacture, 1999, Vol. 39, pp. 253-271, ISSN 0890-6955.

[206]. Wang, M. Y.: The fixturing pyramid. Assembly Automation, 2002, Vol. 22, No. 2, pp. 103-104, ISSN 0144-5154.

[207]. Wang, M. Y.: Tolerance analysis for fixture layout design, Assembly Automation, 2002, Vol. 22, No. 2, pp. 153-162, 0144-5154.

[208]. Wang, Y., Xie, J. F., Wang, Z. J., Gindy, N.: A parametric FEA system for fixturing of thin-walled cylindrical components. Journal of Materials Processing Technology, 2008, Vol. 205, No. 1-3, pp. 338-346, ISSN 0924-0136

[209]. Wang, Y., Chen, X., Gindy, N., Xie, J.: Elastic deformation of a fixture and turbine blades system based on finite element analysis. International Journal of Advanced Manufacturing Technology, 2008, Vol. 36, No. 3-4, pp. 296-304, ISSN 0268-3768.

[210]. Wang, H., Rong, Y. M.: Case based reasoning method for computer aided welding fixture design. Computer-Aided Design, 2008, Vol. 40, No. 12, pp. 1121-1132, ISSN 0010-4485.

[211]. Wang, Y., Hodgson, A., Chen, X., Gindy, N.: A methodology for the development of machining fixtures for components with complicated geometry. International Journal of Computer Integrated Manufacturing, 2008, Vol. 21, No. 7, pp. 848-856, ISSN 0951-192X.

[212]. Wang, Y., Wang, Z., Gindy, N.: Collision-free machining fixture space design based on parametric tool space for five-axis grinding. International Journal of Advanced Manufacturing Technology, 2009, Vol. 45, No. 1-2, pp. 1-7, ISSN 0268-3768.

[213]. Whybrew, K. and Ngoi, B. K. A.: Computer aided design of modular fixture assembly. The International Journal of Advanced Manufacturing Technology, 1992, Vol. 7, No. 5, pp. 267-276, ISSN 0268-3768. 
[214]. Wu, Y., Rong, Y., Chu, T. C.: Automated generation of dedicated fixture design. International Journal of Computer Applications in Technology, 1997, Vol. 10, No. 3-4, pp. 213-235, ISSN 0952-8091.

[215]. Wu, Y., Rong, Y., Ma, W., LeClair, S. R.: Automated modular fixture planning: Geometric analysis. Robotics and Computer-Integrated Manufacturing, 1998, Vol. 14, No. 1, pp. 1-15, ISSN 0736-5845.

[216]. Wu, Y., Rong, Y., Ma, W., LeClair, S. R.: Automated modular fixture planning: Accuracy, clamping, and accessibility analyses. Robotics and Computer-Integrated Manufacturing, 1998, Vol. 14, No. 1, pp. 17-26, 0736-5845.

[217]. Wu, Y. G., Gao, S. M., Chen, Z. C.: Automated modular fixture planning based on linkage mechanism theory. Robotics and ComputerIntegrated Manufacturing, 2008, Vol. 24, No. 1, pp. 38-49, ISSN 07365845 .

[218]. Xiong, C. H., Li, Y. F., Rong, Y. K., Xiong, Y. L.: Qualitatilve analysis and quantitative evaluation of fixturing. Robotics and ComputerIntegrated Manufacturing, 2002, Vol. 18, No. 5-6, pp. 335-342, ISSN 0736-5845.

[219]. Xiong, Y. L., Xiong, X. R.: On complex fixture - Part 1: Mathematical descriptions. 19th IEEE International Conference on Robotics and Automation (ICRA), Washington, USA, 2002, pp. 2900-2905, ISBN 07803-7272-7

[220]. Xiong, Y. L., Xiong, X. R.: Algebraic structure and geometric interpretation of rigid complex fixture systems. IEEE Transactions on Automation Science And Engineering, 2007, Vol. 4, No. 2, pp. 252-264, ISSN 1545-5955.

[221]. Xiong, C. H., Wang, M. Y., Xiong, Y. L.: On clamping planning in workpiece-fixture systems. IEEE Transactions on Automation Science and Engineering, 2008, Vol. 5, No. 3, pp. 407-419, ISSN 1545-5955.

[222]. Yu, K. M., Lam, T. W., Lee, A. H. C.: Immobilization check for fixture design. Proceedings of the Institution of Mechanical Engineers - Part B - Journal of Engineering Manufacture, 2003, Vol. 217, No. 4, pp. 499512, ISSN 0954-4054.

[223]. Zaitsu, I., Aoyama, H., Aoyama, T.: Fixturing feature for determining optimum clamping points: Concept of fixturing feature and its application to 2-D and 3-D workpiece models. 10th International 
Conference on Precision Engineering (ICPE), Yokohama, Japan, 2001, pp. 887-891, ISBN 0-7923-7414-2.

[224]. Zbigniew, M.: Genetic Algorithms + Data Structures = Evolution Programs, Springer, 1996, 387 p., ISBN 978-3-540-60676-5.

[225]. Zheng, Y., Rong, Y., Hou, Z.: A finite element analysis for stiffness of fixture units. Journal of Manufacturing Science and Engineering, 2005, Vol. 127, No. 2, pp. 429-432, ISSN 1087-1357.

[226]. Zheng, Y., Rong, Y., Hou, Z.: The study of fixture stiffness part I: a finite element analysis for stiffness of fixture units. International Journal of Advanced Manufacturing Technology, 2008, Vol. 36, No. 9-10, pp. 865-876, ISSN 0268-3768.

[227]. Zheng, Y., Hou, Z., Rong, Y.: The study of fixture stiffness - Part II: contact stiffness identification between fixture components. International Journal of Advanced Manufacturing Technology, 2008, Vol. 38, No. $1-$ 2, pp. 19-31, ISSN 0268-3768.

[228]. Zheng, Y., Qian, W. H.: A 3-D modular fixture with enhanced localization accuracy and immobilization capability. International Journal of Machine Tools \& Manufacture, 2008, Vol. 48, No. 6, pp. 677-687, ISSN 0890-6955.

[229]. Zhu, X. Y., Ding, H.: Optimality Criteria for Fixture Layout Design: A Comparative Study. IEEE Transactions on Automation Science and Engineering, 2009, Vol. 6, No. 4, pp. 658-669, ISSN 1545-5955.

[230]. Zhong, W. P., Hu, S. J.: Modeling machining geometric variation in a $\mathrm{N}-2-1$ fixturing scheme. Journal of Manufacturing Science and Engineering, 2006, Vol. 128, No. 1, pp. 213-219, ISSN 1087-1357.

[231]. Župerl, U., Čuš, F.: A model for analysing and optimazing fixtures. Strojniški Vestnik - Journal of Mechanical Engineering, 2002, Vol. 48, No. 2, pp. 73-86, ISSN 0039-2480.

[232]. ---: Jig \& Fixture Design Tools, Siemens PLM Software, Siemens United Kingdom, http://www.siemens.co.uk, 2008.

[233]. ---: Thomson Reuters - Technical Support Reference Search, Web of Science, http://apps.isiknowledge.com, 2010.

[234]. ---: Machining Fixture, Bluco Corporation, http://www.bluco.com, 2008.

[235]. ---: Standard Parts (Machine and Fixture Elements, Clamping Elements, Operating Elements, Machine Elements, Basic Elements), Erwin Halder KG, http://www.halder.de, 2008. 
[236]. ---: Fixture elements, CFM-Itbona LLC, http://www.itbona.com, 2009.

[237]. ---: Fixture Design and Manufacturing, Carr Lane Manufacturing Co, http://www.carrlane.com, 2009.

[238]. ---: Flexible standard component system, Systems and components for mechanical engineering, Norelem, www.norelem.com, 2009.

[239]. ---: Workholding Solutions - Automated Fixtures, Ahaus Tool \& Engineering, http://www.ahaus.com, 2008.

[240]. ---: Assembly Fixture, Bisiach \& Carru, http://www.bisiachcarru.it, 2008.

[241]. ---: CNC Capabilities Brochure - Fixtures for CNC machining, CNC Machining Technologies, http://www.cnc-technology.com, 2009.

[242]. ---: Algorithmic Automation: Part Fixturing, University od California Berkeley, Department of Industrial Engineering and Operations Research http://www.ieor.berkeley.edu, 2008.

[243]. ---: Mechanical components, Föhrenbach, http://www.foehrenbach.com, 2009.

[244]. ---: Fixtures, At Proto Tool Co, http://www.prototoolco.com, 2008

[245]. ---: Tooling Components, Drill Bushings, Toggle Clamps, Lifting Clamps, Hydraulic Clamps, All American Products Group, http://www.allamericanproducts.com, 2008.

[246]. ---: Spring Loaded Devices, Quick Release Devices Leveling Devices, Mechanical Components, Vlier, http://www.vlier.com, 2008.

[247]. ---: Tooling Components - Clamping \& Work-Holding, Northwestern Tools, Inc. http://www.northwesterntools.com, 2009.

[248]. ---: Fixture Engineering \& Manufacturing, Royal Machine \& Tool Corporation, http://www.royalworkholding.com, 2009.

[249]. ---: Fixturing component, Fixtures design, R\&R Sales and Engineering http://www.cmmfixtures.com, 2009. 